


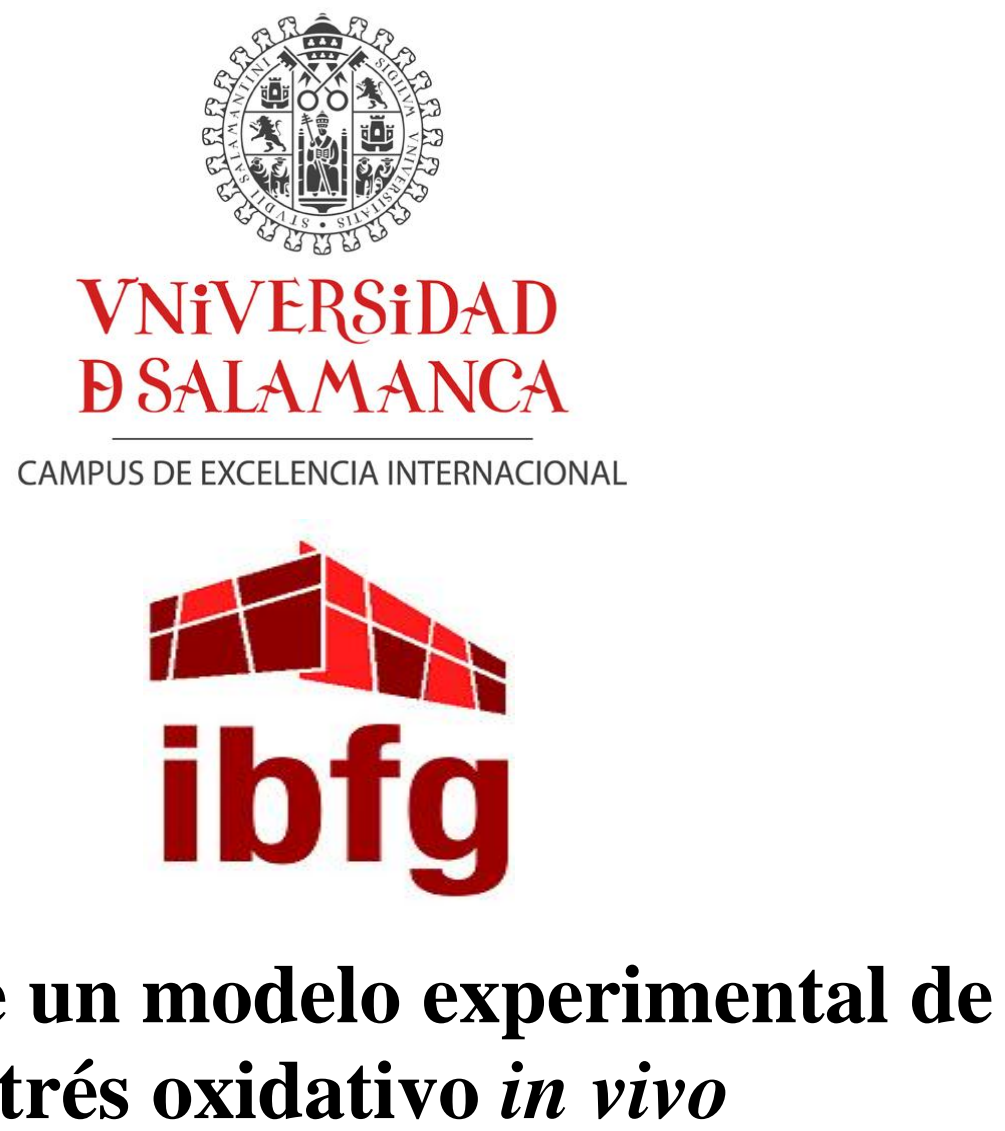

Memoria presentada por Seila Fernández Fernández para optar al Título de Doctor Europaeus

Directores:

Prof. Dr. D. Juan Pedro Bolaños Hernández Prof $^{a}$. Dra. D ${ }^{\mathrm{a}}$. Ángeles Almeida Parra 
Juan Pedro Bolaños Hernández, Catedrático de Bioquímica y Biología Molecular de la Universidad de Salamanca, y Ángeles Almeida Parra, Investigadora del Hospital Universitario de Salamanca y Profesora Asociada del Departamento de Bioquímica y Biología Molecular de la Universidad de Salamanca.

AUTORIZAN:

La presentacion de la Tesis Doctoral titulada "Desarrollo de un modelo experimental de estrés oxidativo in vivo", que ha sido realizada bajo su dirección por la Licenciada en Bioquímica Dña. Seila Fernández Fernández, en el Departamento de Bioquímica y Biología Molecular y en el Instituto de Biología Funcional y Genómica, de la Universidad de Salamanca. En nuestra opinión, reúne todos los requisitos científicos y formales para ser defendida y optar al Título de Doctor Europaeus.

Salamanca, a 7 de Marzo de 2013 


$$
\begin{gathered}
\text { Para S. . ternández } \\
\text { (Santiago, Sabina, Silvia, Saúl } \\
\text { y Sara) } \\
\text { y - Ernando León Lobera }
\end{gathered}
$$


No digáis que, agotado su tesoro, de asuntos falta, enmudeció la lira; podrá no haber poetas, pero siempre habrá poesía.
Mientras las ondas de la luz al beso palpiten encendidas, mientras el sol las desgarradas nubes de fuego y oro vista, mientras el aire en su regazo lleve perfumes y armonías, mientras haya en el mundo primavera, ¡habrá poesía!

Mientras la ciencia a descubrir no alcance las fuentes de la vida, y en el mar o en el cielo haya un abismo que al cálculo resista, mientras la humanidad siempre avanzando no sepa a dó camina, mientras haya un misterio para el hombre, ¡habrá poesía!

Gustavo Adolfo Bécquer. Rima IV. Rimas y Leyendas (Rhyme IV.Rhymes and Legends.) 


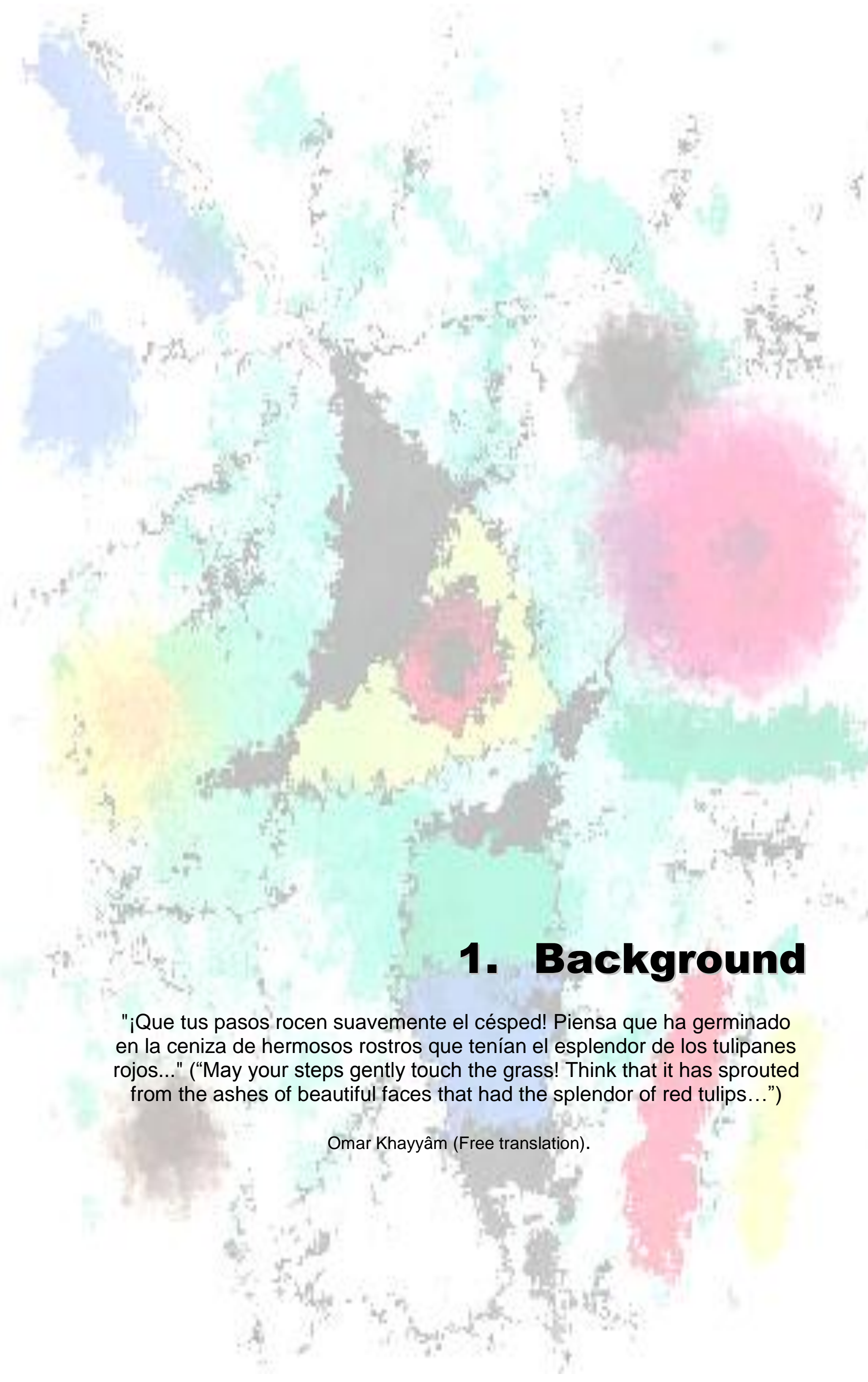




\section{Oxidative stress}

Reactive oxygen species (ROS), mostly $\mathrm{O}_{2}{ }^{\cdot-}, \mathrm{H}_{2} \mathrm{O}_{2}$ and ${ }^{\circ} \mathrm{OH}$, are produced physiologically in basal levels, regulating protein function, gene expression, as well as cell proliferation and differentiation (Halliwell, 2011; Rebrin and Sohal, 2008). Under certain circumstances, the rate of ROS formation overcomes the capacity of antioxidant systems to detoxify them. This situation, oxidative stress, provokes over-oxidation of proteins (at cysteine and aromatic residues), nucleic acids and lipids (Poyton et al., 2009; Temple et al., 2005). A major proportion of cellular ROS are produced within mitochondria, hence becoming the organelle most prone to the actions of ROS, including peroxidation of lipids, oxidation of Fe-S clusters of proteins including some respiratory chain complexes and aconitase, and formation of 8-oxo-desoxiguanosine in mitochondrial DNA (mtDNA) (Fukui and Moraes, 2008; Hekimi et al., 2011). These alterations may lead to important changes in lipid structures, mitochondrial energy production and, possibly, ${ }_{\mathrm{m}} \mathrm{DNA}$ mutations. The ultimate consequences of massive insults due to improperly balanced ROS -oxidative stress- could ultimately trigger macro-autophagy and cell death (Brand, 2010). Moreover, excessive ROS formation is associated with aging (Rebrin and Sohal, 2008), cancer, cardiovascular, immune and neurodegenerative diseases (Bolaños et al., 2009; Halliwell, 2011; Temple et al., 2005).

There are several known ROS production sites within mitochondria, although complexes I and III seem to be the most important quantitatively (Brand, 2010). Thus, complex I (Murphy, 2009; Poyton et al., 2009) and III donate individual electron to molecular oxygen (Murphy, 2009) generating superoxide anion $\left(\mathrm{O}_{2}{ }^{\circ-}\right)$ (Boveris, 1984). This process is regulated by the redox and energy status, suggesting that $\mathrm{O}_{2}{ }^{--}$formation by this way plays physiological functions (D'Autreaux and Toledano, 2007; Poyton et al., 2009). For instance, $\mathrm{O}_{2}{ }^{--}$formation by complex $\mathrm{I}$ is increased when the $\mathrm{NADH}\left(\mathrm{H}^{+}\right) / \mathrm{NAD}^{+}$ratio and electrochemical gradient are high (Murphy, 2009). On the other hand, $\mathrm{O}_{2}{ }^{--}$reactivity is limited when compared to other ROS, although it can reduce $\mathrm{Fe}^{3+}$ to $\mathrm{Fe}^{2+}$ by the Haber-Weiss reaction that can ultimately lead to hydroxyl radical $(\mathrm{OH})$ formation by the Fenton reaction, which re-oxidizes $\mathrm{Fe}^{2+}$ to $\mathrm{Fe}^{3+}$ using previously formed $\mathrm{H}_{2} \mathrm{O}_{2}$ (Temple et al., 2005). 
Besides mitochondria, $\mathrm{O}_{2}{ }^{--}$can also be formed in the cytosol by lipooxigenase, cyclooxigenase, xanthine oxidase, and NADPH oxidase (Circu and Aw, 2010; Temple et al., 2005).

\subsection{Antioxidant systems}

To counteract the actions of ROS, several antioxidant systems have evolved. Cytosolic (Cu/Zn-SOD or SOD1), mitochondrial (Mn-SOD or SOD2) and extracellular (SOD3) superoxide dismutases converts $\mathrm{O}_{2}{ }^{-\cdot}$ into hydrogen peroxide $\left(\mathrm{H}_{2} \mathrm{O}_{2}\right)$. Due to its pro-oxidant properties, $\mathrm{H}_{2} \mathrm{O}_{2}$ must be quickly inactivated by reduction to $\mathrm{H}_{2} \mathrm{O}$. The most important $\mathrm{H}_{2} \mathrm{O}_{2}$ detoxifying system are catalase -which is placed in peroxisomes-, peroxirredoxins (Prxs) -which require thioredoxin and thiorredoxine reductase to be regenerated-, and glutathione peroxidases (GPxs) -which require glutathione and glutathione reductase (GSR) to be regenerated. Both Prxs and GPxs, which exists under several isoforms, are present both in the mitochondria and in the cytosol (Hekimi et al., 2011; Mari et al., 2009; Temple et al., 2005). It is noteworthy the ability of $\mathrm{H}_{2} \mathrm{O}_{2}$ to react with certain cysteine residues of proteins in a selective fashion (Le Moan et al., 2006). The most abundant small thiol, glutathione (GSH), plays a critical role in the cell's antioxidant machinery not only because of its function as GPxs' cofactor, but also because it directly forms S-glutathionylated aducts in proteins (D'Autreaux and Toledano, 2007).

It is noteworthy the high dependence of several antioxidant enzymes on GSH as cofactor. The GPxs family catalyzes the reduction of $\mathrm{H}_{2} \mathrm{O}_{2}$, and other organic peroxides, using either GSH (or thiorredoxin) as cofactors (Maiorino et al., 2007). Only GPxisoform 1 (GPx1) prefers GSH as cofactor (Flohe et al., 1971; Maiorino et al., 2007; Takebe et al., 2002), although its activity is also dependent on NADPH supply (Flohe, 2009; Toppo et al., 2009). GPx4, which is exclusively localized in the mitochondria, has an important role reducing lipid peroxides (Flohe et al., 1971; Toppo et al., 2009). Glutaredoxins (Grxs) are versatile oxidoreductases that glutathionylate proteins reversibly (Zeevalk et al., 2008), although they also have dihydroascorbate reductase activity (Wells et al., 1990). Glutathione-S-transferases (GSTs), which show different kinetic properties depending on the isoform and localizaiton -cytosolic or 
mitochondrial- (Hayes et al., 2005), detoxify electrophyle groups, using GSH as cofactor (Douglas, 1987), although it can also use $\gamma$-glutamylcysteine $(\gamma \mathrm{GC})$ (Sugimoto et al., 1985). $\gamma$-Glutamiltranspeptidase (GGT), which is present in the plasma membrane, detoxifies xenobiotic using GSH as cofactor, and plays and essential role against oxidative stress (Paolicchi et al., 2002; Paolicchi et al., 2003), but it also modulates S-thiolation events (Pompella et al., 2007). Other compounds with antioxidant activity, such as ascorbate or vitamine E, do not necessarily depend on thiols as cofactors, as they directly trap radicals hence acting as scavengers. However, some of these require GSH to be regenerated, such as the pair ascorbate/dehydroascorbate (Harrison and May, 2009).

\section{Glutathione}

GSH ( $\gamma$-L-glutamyl-L-cysteinyil-glycine) is the most abundant small thiol antioxidant (0.5-10 mmol/L) in animal cells and tissues (Meister and Anderson, 1983). It is also essential for the maintenance of cellular redox state and viability (Lu, 2009). GSH is mainly present in the cytosol (85-90\%), where it has a half-life of 2-3 h; the rest is mainly mitochondrial (10-15\%) (Lu, 2009; Meredith and Reed, 1982). However, GSH can also be found in the nucleus, endoplasmic reticulum and peroxisomes ( $\mathrm{Lu}$, 2009; Wu et al., 2004b). In the brain, GSH has a mean concentration of 1-3 mM (Dringen, 2000), although it has a heterogeneous cellular distribution. Thus, in neurons, GSH is present at $\sim 2.5 \mathrm{mM}$, whereas in astrocytes it is $>3.5 \mathrm{mM}-$ found at $\sim 8 \mathrm{mM}$ in culture- (Dringen, 2000; Zeevalk et al., 2008). Most glutathione is present in its reduced form (GSH), with only a small fraction (1-5\%) oxidized (GSSG) (Zhao et al., 2010). The glutathione redox status (GSH/GSSG) is, therefore, $>10$ under physiological conditions (Jones et al., 2002; Schafer and Buettner, 2001). The main pathway of GSH regeneration from GSSG is GSR (Rahman et al., 1999), which therefore also contributes to the defense against oxidative stress (Kelner and Montoya, 2000), and requires NADPH as cofactor.

\subsection{GSH functions}


Besides its role as a cofactor, GSH can spontaneously react with $\mathrm{O}_{2}{ }^{--}$(Ross et al., 1985; Wefers and Sies, 1983; Winterbourn and Metodiewa, 1994), $\mathrm{OH}^{\circ}$, nitric oxide (NO), singlet oxygen $\left({ }^{1} \mathrm{O}_{2}\right), \mathrm{H}_{2} \mathrm{O}_{2}$, peroxynitrite $\left(\mathrm{ONOO}^{-}\right)$or lipid peroxides ( $\mathrm{LOO}^{\circ}$ ), oxidizing itself (GS') to form GSSG (Franco and Cidlowski, 2009) (Franco and Cidlowski, 2009). However, these direct reactions are minor. Most GSH is thought to be employed in detoxifying xenobiotics through the formation of conjugates in reactions catalyzed by GST (Meister, 1988). GSH can also serve as a cysteine reservoir and transporter through the $\gamma$-glutamile cycle (Lu, 2009; Meister and Anderson, 1983). GSH maintains the redox status of peptide thiols (Cotgreave and Gerdes, 1998) and interchanges thiol disulfides reversibly depending of the GSH/GSSG redox equilibrium (Lu, 2009). Thus, GSH can modulate protein function post-translationally by reacting with cysteine residues in the catalytic- or ligand-binding sites. These reactions are reversible and include nitrosilation (SNO), hydroxylation (SOH), disulfide formation (S-S) or glutathionylation (SSG) (Franco and Cidlowski, 2009). In the central nervous system, by altering the redox status of glutamatergic, GABAergic or dopaminergic receptor proteins (Heales et al., 1999; Hogg, 2002; Oja et al., 2000), GSH is thought to modulate the homeostasis of neural messengers, including NO, glutamate or GABA. Other functions of GSH are related to cell proliferation (Lu, 2009) and cellular survival (Garcia-Ruiz and Fernandez-Checa, 2007), as thiolation of proteins by Grxs, allows GSH to modulate gene expression, as well as the synthesis and repair of DNA and proteins (Dalle-Donne et al., 2007).

\subsection{GSH biosynthesis}

Glutathione is synthesized by two consecutive ATP-dependent reactions. Glutamatecysteine ligase (GCL or $\gamma$-glutamylcysteine synthetase; EC 6.3.2.2) catalyzes the first and rate-limiting- step, forming $\gamma$-glutamylcysteine from glutamate and cysteine (Figure 1) (Orlowski and Meister, 1971). This is followed by the glutathione synthetase (EC 6.3.2.3)-catalyzed reaction, which binds glycine to $\gamma$-glutamylcysteine, forming glutathione (Figure 1) (Huang et al., 1995). GCL is a heterodimeric enzyme composed of a catalytic (heavy; $73 \mathrm{kDa}$ ) (Huang et al., 1993b) and a modulatory (light; $27.7 \mathrm{kDa}$ ) (Makar et al., 1994) subunit. Studies performed with purified GCL have shown that the active site residues are in the catalytic subunit, whereas the modulatory subunit increases the affinity of the catalytic subunit for glutamate (Huang et al., 1993b) and 
decreases the sensitivity to feedback inhibition by GSH and decreases the la $K_{m}$ for ATP (Chen et al., 2005) and glutamate (Huang et al., 1993a; Huang et al., 1993b). In the brain, where -to the best of our knowledge- the enzyme has never been purified, GCL activity is very weak (Orlowski and Meister, 1971), although it is higher in astrocytes when compared with neurons (Dringen et al., 1999a; Gegg et al., 2003; Makar et al., 1994). This contributes to the higher resistance of astrocytes, when compared with neurons, against oxidative stress (Bolaños et al., 1995; Dringen et al., 1999a).

\subsection{Regulation of GSH biosynthesis}

Glutathione synthesis de novo is regulated by at least three factors, including i) the expression of its rate limiting enzyme GCL, ii) the availability of its limiting amino acid precursor L-cysteine (Wu et al., 2004b) and iii) the feedback inhibition of GCL by GSH (Griffith, 1999; Wu et al., 2004a). Other factors, such as phosphorylation and nitration of GCL, are secondary. ATP dependence for GSH synthesis (Suzuki and Kurata, 1992), explains lower GSH synthesis in glucose deprivation events such as diabetes or stroke (Griffith, 1999; Papadopoulos et al., 1997). GSH is degraded in the extracellular space through the $\gamma$-glutamyl cycle by GGT, which contributes to its recycling via the de novo synthesis (Anderson and Meister, 1983; Njalsson, 2005).

GCL is regulated both at the transcriptional and post-transcriptional levels. Oxidative and nitrosative stress, through the activation of antioxidant response elements (ARE), localized in the promoter region of antioxidant genes ( $\mathrm{Lu}, 2000$; Wu et al., 2004a), transcriptionally activate GCL (Kang et al., 2005). The transcription factor of the bZIP family (basic leucine zipper), Nrf2, plays an essential role in this response. Nrf2 is sequestered in the cytosol by the repressor protein Keap1 but, upon an oxidative stress insult, it is translocated to the nucleus forming heterodimers with Maf family proteins to bind ARE sequences, promoting the expression of antioxidant genes (Kang et al., 2005; Minelli et al., 2009), in particular both subunits of GCL. Neurotrophic factors can also increase GSH biosynthesis (Dringen, 2000). The GCL promoter also contains elements of response to electrophiles (EpRE) (Wild et al., 1999), where the activator AP-1 protein family binds, including Jun y Fos transcription factors (Rahman, 2005). In

addition, GSH promoter also contains two E-box sequences where c-Myc or N-Myc can 
bind in response to $\mathrm{H}_{2} \mathrm{O}_{2}$ (Benassi et al., 2006; Veas-Perez de Tudela et al., 2010). Nuclear transcription factor kappa-B (NFkB) site is only present in GCL, catalytic subunit promoter, and increases its expression in response to tumor necrosis factor $\alpha$ (TNF $\alpha$ ) or oxidative stress (Rahman, 2005). Other GCL transcription activators are Sp1, AP-2, or the metal response element (MRE) (Lu, 2009). GSS promoter contains binding sites elements for activator AP-1 or inhibitor NF1, (Yang et al., 2002a). In humans, Nrf1 and Nrf2 induce the GSS promoter, being Nrf2 essential to basal concentrations of the enzyme (Lee, 2005). Nrf2 also induces GGT (Pompella et al., 2007)

Post-transcriptional regulation of GCL is based mainly in the mRNA stability and in post-translational modifications. GCL, catalytic subunit, activity decreases upon phosphorylation of protein kinases A (PKA) or C (PKC), or $\mathrm{Ca}^{2+}$-calmodulin dependent protein kinase II (CaMKII) (Lu, 2009; Soltaninassab et al., 2000). This kind of phosphorylation has not been found in GCL, modulatory subunit (Soltaninassab et al., 2000). GCL can be inhibited by NO through nitrosylation, or by nitrosylating compounds (Griffith, 1999). Caspase 3 is able to excise GCL, catalytic subunit, from the GCL holoenzyme (Franklin et al., 2002), contributing to apoptosis by lowering GSH concentrations.

\section{Astrocytes co-operate with neurons in GSH homeostasis}

Astrocytes co-operate with neurons for neuronal antioxidant GSH biosynthesis (Dringen, 2000; Dringen et al., 1999b). In fact, astrocytes orchestrate the main antioxidant response through Nrf2 activation that regulates GSH synthesis, amongst other factors (Scheme 1) (Fernandez-Fernandez et al., 2012). Exogenous administration of GSH is not effective to increase GSH concentration as GSH is not imported to the cells and it is quickly degraded (Griffith, 1999). Astrocytes appear to be the only cells in the brain that release significant amounts of GSH or GSSG upon oxidative stress, being MRP1 the main mechanism of both molecules exportation (Dringen and Hirrlinger, 2003; Hirrlinger et al., 2001). In fact, inhibition of MRP1 activity reduces to a 70\% the exportation of GSH, diminishing the supply of GSH precursor for GSH de novo synthesis (Scheiber and Dringen, 2011). GSH released from astrocytes are prone to transpeptidation to cysteinylglycine (CysGly) or to $\gamma$-glutamyl-aminoacid, catalyzed by 
GGT. This is the first step of GSH uptake by neurons (Sagara et al., 1993; Zeevalk et al., 2008). Neurons also import CysGly trough the aminopeptidase N (ApN) (Dringen et al., 2001). Neurons preferably use CysGly, NAC or $\gamma$ GC as GSH precursors upon dipeptidase excision (Dringen, 2000; Stull and Martin, 2009). To a lower extent, GSSG released by astrocytes also serve as GSH precursors (Dringen, 2000).

Thus, astrocytes supply GSH precursors to neurons (Bolanos and Heales, 2010; Dringen, 2000; Dringen et al., 1999b) through a complex mechanism (Scheme 1) that constitutes an essential antioxidant strategy. Our group previously demonstrated that, genetic modulation of GSH biosynthesis by knocking down or over-expressing GCL, catalytic subunit, strongly influences the vulnerability of cultured primary neurons against excess nitric oxide and excitotoxicity (Diaz-Hernandez et al., 2005). Noticeably, the presence of neighboring astrocytes in co-culture was not sufficient to prevent the neuronal apoptotic death caused by GCL loss; this confirms that neurons require an intact GSH biosynthetic machinery to build up GSH from its precursors. Thus, limiting either the supply of GSH precursors, or the ability of neurons to use them, triggers oxidative stress in neurons leading to neurodegeneration, at least in culture. This has led us to hypothesize that neuronal-specific and temporally-controlled knockdown of GCL in vivo may lead to spontaneous neurological dysfunction, thus possibly mimicking the neurological problems associated with Parkinson’s or mental diseases.

\section{Oxidative stress and neurodegeneration}

Neurons have high energetic requirements to produce nerve impulses, and the mitochondrial oxidative metabolism accounts for its primary energy source. Insufficient ATP production and increased ROS levels (Bolaños et al., 2009; Levy et al., 2009) converge frequently in neuronal apoptosis. On the other hand, the loss of mitochondrial functionality is obvious in aging processes, when the accumulation of ${ }_{\mathrm{mt}} \mathrm{DNA}$ mutations and mitochondrial complexes activity decays, particularly complex I (Barja, 2004), which contributes to explain the appearance of associated pathologies (Bolaños et al., 2009; Halliwell, 2011; Temple et al., 2005). The deleterious effects of ROS occur during adulthood, and it has been suggested that oxidative stress may be a contributing factor in neurodegenerative processes (Curtis et al., 2012). GSH deficiency is the earliest known biochemical indicator of neuronal degeneration such as Parkinson's 
disease or mental disorders, (Jenner et al., 1992; Liu et al., 2004; Perry et al., 1982). This observation has led to the suggestion that oxidative stress may be behind the causes of neuronal dysfunction associated with these neurological disorders (Andersen, 2004; Chinta and Andersen, 2008). Unfortunately, due to the lack of a sufficiently robust tool, the specific effect of GSH deficiency in the pathogenesis of neurological diseases has never been shown in vivo (Barja, 2004), thus the actual role of GSH lossmediated oxidative stress in these disorders still remains elusive.

\section{Animal models for studying GSH metabolism}

GSH deficiency has severe consequences in humans. GCL deficiency causes hemolytic anemia, dyslexia and metabolic acidosis alongside with mental retardation, spine-cerebellar degeneration or neuromuscular alterations (Njalsson, 2005). There are known GCL polymorphisms and genetic mutations of GCL that account for GSH deficiency (Dalton et al., 2004). GSS loss of function is lethal (Shi et al., 1996). Mild deficiency causes hemolytic anemia and metabolic acidosis (Polekhina et al., 1999); these patients also show mental retardation and motor impairments (Ristoff and Larsson, 1998). These evidences have aimed to several groups to generate animal models to study the effects of GSH metabolism impairment.

Despite its importance, GPx1 KO mice are viable and fertile, though with an extreme sensitivity to oxidative stress (Toppo et al., 2009). On the other hand GPx4 KO mice exhibit prenatal lethality, possibly due to its ability to maintain lipid membranes in the reduced state and prevent apoptosis (Yant et al., 2003). GST KO mice for several isoforms are highly prone to xenobiotics, oxidative stress and bacterial infection, showing a greater inhibition of the anti-inflammatory response (Hayes et al., 2005). GGT deficient mice (GGT KO), exhibit a chronic decrease in GSH, low plasma levels of cysteine, sexual immaturity, stunting, development of cataracts and premature death (Lieberman et al., 1996; Will et al., 2000). None of these models are specific for brain tissues. GCL, modulatory subunit, KO mice are viable; however, despite their lower GSH content, they do not present relevant physiological consequences but a greater susceptibility to oxidative stress and lower cysteine content (Dalton et al., 2004; Yang et al., 2002b). The existing in vivo models for studying GCL, catalytic subunit, deficiency in the brain are scarce and failed. Homozygous $K O$ mice against GCL, 
catalytic subunit, are not viable beyond embryonic day $8^{\text {th }}$, and the heterozygous ones display compensation mechanisms such as increased ascorbate biosynthesis (Dalton et al., 2000; Shi et al., 2000). In addition, this mouse does not knockout GCL tissue specifically or temporally controlled, thus being unsuitable to investigate the role of oxidative stress in central nervous system during adulthood.

In our group, we previously identified a small hairpin RNA (shRNA) targeted against GCL, catalytic subunit that, in cultured neurons, triggered spontaneous oxidative stress (Diaz-Hernandez et al., 2005). However, it is unknown whether implementing this RNA interference (RNAi) strategy in vivo would be able to generating a conditional mice expressing GCL shRNA in central nervous system neurons, particularly hippocampal neurons. We believe that this model, if successful, would provide the first tissue specific and inducible model of oxidative stress suitable for, e.g. understanding the molecular mechanisms underlying neurological diseases, as well as for scanning possible therapeutic strategies against these disorders. 


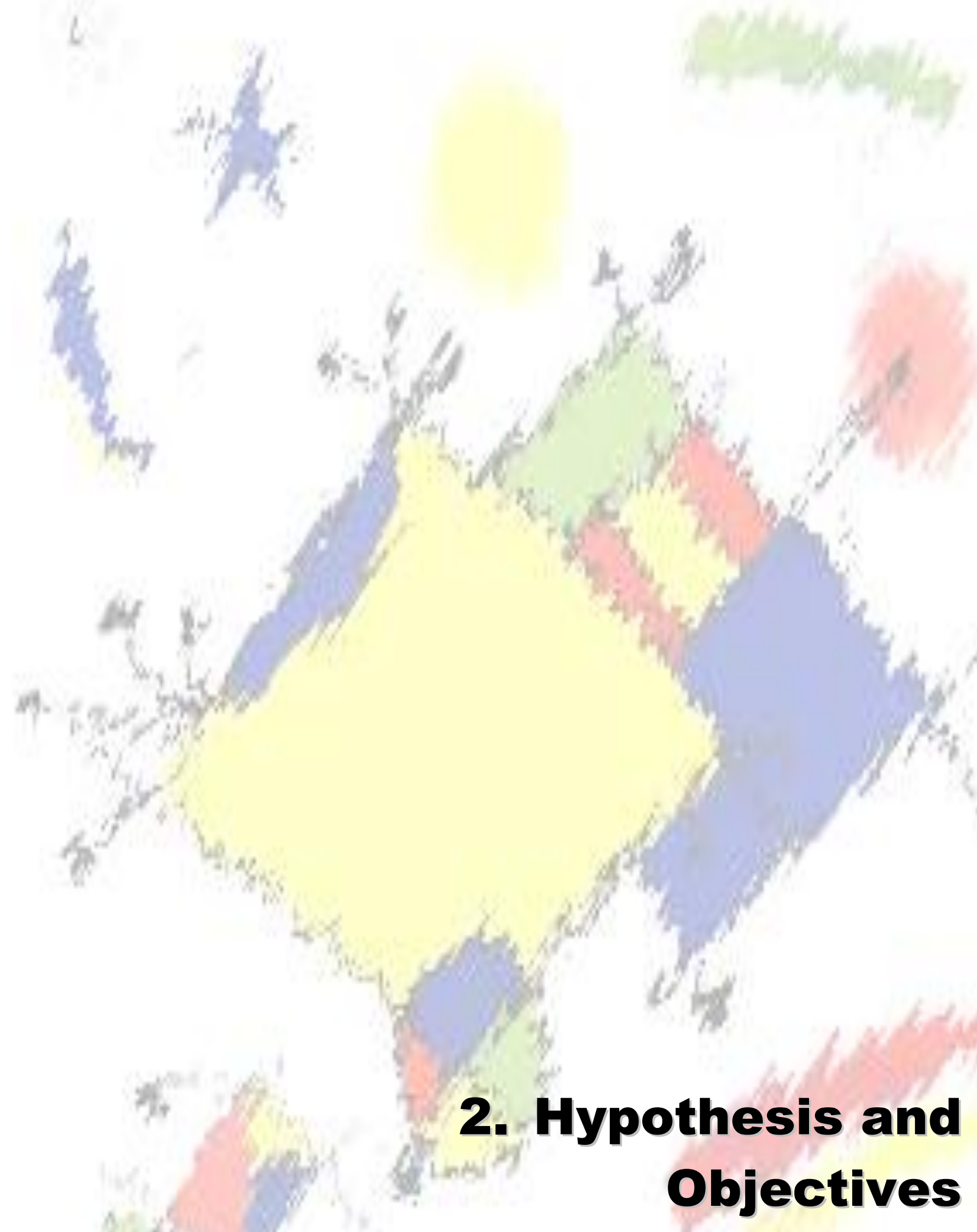

"I had retrod the steps of knowledge along the paths of time and exchanged the discoveries of enquirers for the dreams of forgotten alchemists.

Mary Shelley. Frankenstein 


\section{Hypothesis}

Our research group previously identified a specific shRNA targeted against GCL, catalytic subunit that, in cultured neurons, spontaneously triggered oxidative stress (Diaz-Hernandez et al., 2005). However, whether implementing this RNAi strategy in vivo would produce a double-conditional mouse expressing the GCL shRNA in the cells of the central nervous system is unknown. We think that this model would provide an excellent tissue specific and inducible model to recreate oxidative stress in vivo.

\section{Objective}

At the light of the above-mentioned backgrounds, the objectives of this Doctoral Thesis were:

1. To design and generate a transgenic mouse harboring a small hairpin RNA (shRNA) against the catalytic subunit of glutamate-cysteine ligase (GCL) (shGCL), flanked by Cre-recombinase specific sites.

2. To generate adult mice expressing shGCL in neurons in vivo using the Crerecombinase methodology.

3. To biochemically, immuno-histologically and behaviorally characterize adult mice expressing shGCL in neurons.

With the expected results, we would like to generate tissue-specific and time-inducible mice with lower glutathione biosynthesis, which may be potentially useful for the identification of novel redox-sensitive proteins involved in neurological disorders. 


\section{Metodology}

"La ciencia es una estrategia, es una forma de atar la verdad que es algo más que materia, pues el misterio se oculta detrás "

Luis Eduardo Aute. De paso. 


\section{shGCL ${ }^{\text {floxed }}$ construct generation}

The shGCL floxed construct was designed and generated to develop a transgenic mouse harbouring a LoxP-flanked shRNA precursor against GCL, catalytic subunit (hereafter shGCL) that is useful to induce tissue- and temporally-controlled GSH deficiency in in vivo situations. This strategy relies on the Cre-LoxP technology were the P1 phagederived Cre recombinase is able to site-specifically recombine (invert or excise) DNA for natural LoxP sites (5'-ATAACTTCGTATAATGTATGCTATACGAAGTTAT-3’) or artificially mutated Lox sited, as Lox2272 (5’ATAACTTCGTATAAAGTATCCTATACGAAGTTAT-3') in an independent manner (Branda and Dymecki, 2004). This construct needs the action of Cre recombinase for effective GCL, catalytic subunit, knockdown. Thus, prior to recombination (Scheme 2.a), shGCL is separated from the Pol-III promoter (H1) by the cDNA encoding the enhanced green fluorescent protein (eGFP) and appropriate LoxP and Lox2272 positions and orientations; in addition, shGCL and H1 promoter have opposite strand orientation. The key of this strategy is that shGCL can be transcribed after Cre-mediated event (Scheme 2.b), which can be tissue specific and/or temporally-controlled by using Cre fused to a mutant, tamoxifen-sensitive form of the estrogen-receptor $\left(\mathrm{ER}^{\mathrm{TM}}\right)$.

The following vectors were used to clone and subclone elements for the construct generation, namely pIRES2-EGFP (Clontech), pSuper-neo/gfp (Oligoengine), pCDNA3.1(+) (Invitrogen), and pEGFP-C1 (Addgene) (Table 1). Additionally, some adaptors were designed and chemically synthesized (Thermo) to introduce LoxP and Lox2272 in the correct orientation, plus the appropriate restriction enzymes sites and other signals (Table 2). For the final construction of shGCL (Diaz-Hernandez et al., 2005), oligonucleotides were annealed and phosphorylated before ligation with the corresponding linearized and dephosphorylated plasmids. Elements from plasmids were excised by restriction enzyme digestion and directly cloned to the linearized plasmids. The new cloned vectors were checked by restriction enzyme assay, and the final clone containing shGCL was sequenced for correct DNA sequence.

\section{Annealing and phosphorylation of oligonucleotides.}

To anneal the forward with the reverse oligonucleotides they were dissolved in sterile, nuclease-free $\mathrm{H}_{2} \mathrm{O}$ to a concentration of $3 \mu \mathrm{g} / \mu \mathrm{l}$. In a 200- $\mu$ l PCR tube, $1 \mu \mathrm{l}$ of each oligonucleotide was mixed with $48 \mu \mathrm{l}$ of annealing buffer, consisting of $100 \mathrm{mM}$ 
potassium or sodium acetate, $2 \mathrm{mM}$ magnesium acetate tetrahydrate, and $30 \mathrm{mM}$ HEPES-KOH pH 7.4 (all reagents from Sigma-Aldrich). The PCR equipment was programmed as follows: $4 \mathrm{~min}$ at $95^{\circ} \mathrm{C}, 10 \mathrm{~min}$ at $70{ }^{\circ} \mathrm{C}, 10 \mathrm{~min}$ at $50{ }^{\circ} \mathrm{C}$, and $10 \mathrm{~min}$ at $37^{\circ} \mathrm{C}$. The tube was removed and left for $5 \mathrm{~min}$ at room temperature, and then placed on ice at least for another $5 \mathrm{~min}$. For phosphorylation, $2 \mu \mathrm{l}$ of the annealed oligonucleotides were mixed with $1 \mu \mathrm{l}$ of T4-polynucleotide kinase (T4-PNK) buffer (Promega), $1 \mu \mathrm{l}$ of $10 \mathrm{mM}$ ATP (Sigma), $1 \mu \mathrm{l}$ of T4-PNK (Promega) and $5 \mu \mathrm{l}$ of $\mathrm{H}_{2} \mathrm{O}$. The mix was incubated for $30 \mathrm{~min}$ at $37^{\circ} \mathrm{C}$. To inactivate T4-PNK, the mix was further incubated for $10 \mathrm{~min}$ at $70{ }^{\circ} \mathrm{C}$, and then cooled for 5 min on ice.

\section{Linearization of vectors and fragment excision}

To linearize the vector, in a plastic Eppendorf-type tube $2 \mu \mathrm{l}$ of the plasmid vector $(1 \mu \mathrm{g} / \mu \mathrm{l})$ were mixed with $3 \mu \mathrm{l}$ of buffer appropriate restriction buffer and $4 \mathrm{U} / \mu \mathrm{g}$ of DNA of each appropriate enzyme, to a final volume of $30 \mu \mathrm{H}_{2} \mathrm{O}$. To dephosphorylate the vector, the following components were added to the digestion mix: $4 \mu \mathrm{l}$ of dephosphorylation buffer (Roche), $1 \mu$ l of alkaline phosphatase (Roche) and $5 \mu \mathrm{l}$ of $\mathrm{H}_{2} \mathrm{O}$. The new mix was incubated for $15 \mathrm{~min}$ at $37^{\circ} \mathrm{C}$, and then inactivated the enzyme by heating at $75{ }^{\circ} \mathrm{C}$ for $10 \mathrm{~min}$ and cooled in ice for $5 \mathrm{~min}$. Linearization was checked by visualizing the product in an agarose gel, in a small aliquot, a unique band of the correct size. In parallel (in the same gel), a preparative lane was prepared to excise and purify the linearized vector using commercially available DNA purification kits (Promega). Excision of fragments from the vector was performed in the same way.

\section{Ligation into vectors and clone generation}

Oligonucleotides or digested fragments were ligated to corresponding vectors. To do so, $2 \mu \mathrm{l}$ of the annealed, phosphorylated oligonucleotides were mixed with $1 \mu \mathrm{l}$ of ligase buffer (Promega), $1 \mu$ of the purified vector (properly digested and dephosphorylated), $5 \mu \mathrm{l}$ of $\mathrm{H}_{2} \mathrm{O}, 1 \mu \mathrm{l}$ of T4-ligase and $1 \mu \mathrm{l}$ of supplied buffer (Promega). The mix was incubated for 1 hour at room temperature, or at $16{ }^{\circ} \mathrm{C}$ overnight. The ligated product was transformed with competent bacteria following standard protocols. In brief, a mix containing ligated DNA and DH5 $\alpha$ competent bacteria was incubated $30 \mathrm{~min}$ on ice and subsequently heated for $45 \mathrm{~s}$ at $42{ }^{\circ} \mathrm{C}$, and then placed immediately on ice for $5 \mathrm{~min}$, left to grow for 30 at $37^{\circ} \mathrm{C}$ and then seeded on LB-agar plates (1\% (w/v) bactotryptone, $0,5 \%(\mathrm{w} / \mathrm{v})$ bacto yeast extract, $1 \%(\mathrm{w} / \mathrm{v}) \mathrm{NaCl}$, and 1,5\% (w/v) granulated Difco Agar, 
$\mathrm{pH}$ 7.5. The plasmid vector was purified using the Wizard-Plus minipreps (Promega) following the manufacturer' instructions, and checked for the presence of the insert by digesting the plasmid vector with proper restriction enzymes in agarose gels. Fragments were cloned in the same way. In Table 3 we show the restriction enzymes (REs) used in this work, together with their recognition sites and commercial sources. The buffer choice was done either following the instructions manual for individual digestions, or the Enzyme X software for double digestions.

\section{Microinjections}

Mice harbouring the shGCL $L^{\text {floxed }}$ construct previously described were generated by DNA microinjection at the Animal Service of the University of Salamanca following standard protocols. Linearized DNA was microinjected in the pre-fertilized pro-nucleus of a onecell state oocyte from hybrid C57B6/CBA F1 background (Scheme 3).

\section{Mouse lines used}

Mice expressing Cre recombinase governed by the neuronal-specific promoter of mouse calcium-calmodulin kinase-II-alpha (CamKII $\alpha$-Cre) were purchased from The Jackson Laboratories in a congenic C57BL/6 background. According to The Jackson Laboratories datasheet, Cre recombinase expression in this mouse is postnatal (from day 14-21 onwards) and confined to the forebrain, specifically to the CA1 pyramidal cell layer of the hippocampus. Upon their arrival at the Animal Service, the CamKII $\alpha$-Cre mice were backcrossed for two generations in a C57BL/6J background, and the filial inter-crossing resulted in the establishment of homozygosis of the transgene. Mice homozygous for the transgenic insert are viable, fertile, normal in size and do not display any gross physical or behavioral abnormalities. C57BL/6J mouse line was purchased from The Jackson Laboratories, required no genotyping and was kept as an in-bred colony.

\section{Mouse embryonic fibroblasts (MEFs) immortalization}

Fibroblasts were prepared from fetal $G C L^{\text {floxed }}$ mice (E13.5). Embryos were processed individually, and the liver and brain tissue were disregarded. The carcass was mechanically disaggregated in $0.25 \mathrm{~g} / \mathrm{ml}$ of trypsin/1 mM EDTA and seeded in a $60 \mathrm{~cm}^{2}$ cell culture dish containing DMEM (Life Technologies) supplemented with 10\% (v/v) fetal bovine serum (Linus) and 25 mM D-glucose. Confluent cells were split 1:3 during 
2 weeks, until the immortalization crisis occurred, which lasted for a further 2 weeks. During this period, fresh medium was replaced every 3 days. One week after the immortalization crisis, single cell colonies were spotted, picked and grew. MEFs were frozen in a mixture of FBS and DMSO (9:1). For experiments involving MEFs, dishes and plates were previously coated with poly-D-lysine $(15 \mu \mathrm{g} / \mathrm{ml})$. Cells were incubated at $37^{\circ} \mathrm{C}$ in a humidified $5 \% \mathrm{CO}_{2}$-containing atmosphere.

\section{Tissue extraction}

Mice were euthanized with $\mathrm{CO}_{2}$ and tissues were extracted within the following $5 \mathrm{~min}$. Mice were decapitated, and their brains were extracted and dissected. We collected the cerebellum, striatum, hippocampus and pre-frontal cortex. For glutathione determinations, tissues were rapidly frozen in liquid $\mathrm{N}_{2}$ in screw cap tubes, and tissue was mechanically disaggregated. For DNA extraction, a small aliquot of tissue was placed in ice and frozen until further processing.

\section{DNA extraction}

DNA was extracted from tails, pelleted cells or tissue samples. Tails (2-5 mm long) either from embryos or weaned mice were collected in tubes, added $400 \mu$ of TENS buffer (100 mM Tris at pH 8, $5 \mathrm{mM}$ EDTA, $200 \mathrm{mM} \mathrm{NaCl}$, and 0.2\% SDS) and $10 \mu \mathrm{l}$ of Proteinase K (800 U/ $\mu \mathrm{l}$; Sigma). Around $2.5 \times 10^{6}$ pelleted cells or $1-2 \mathrm{mg}$ of tissue

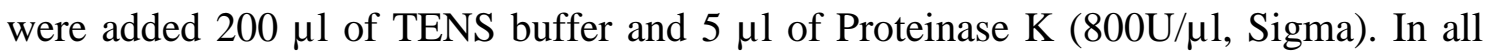
cases, the mix was left overnight at $55{ }^{\circ} \mathrm{C}$ for complete digestion; for tails, $410 \mu \mathrm{l}$ of Phenol-Chloroform-Isoamilic acid (FCI) mix (25:24:1) was then added, and the tubes inverted and centrifuged at 13,000 rpm for $5 \mathrm{~min}$. The aqueous phase was transferred to a new tube, to which an equal volume of isopropanol was added, kept at $4{ }^{\circ} \mathrm{C}$ for at least $30 \mathrm{~min}$, and centrifuged at 13,000rpm for $5 \mathrm{~min}$ at $4{ }^{\circ} \mathrm{C}$. The tube was carefully inverted for the DNA pellet to remain attached to the bottom of the tube, and the liquid was discarded. For salt clearance, $500 \mu \mathrm{l}$ of pre-chilled $70 \%(\mathrm{v} / \mathrm{v})$ ethanol was added, and the excess liquid discarded, as described above. Tubes were left to dry for no more than $5 \mathrm{~min}$, and $50 \mu \mathrm{l}$ of TE buffer solution (10 mM Tris- $\mathrm{HCl}$ at $\mathrm{pH} 8$ in $1 \mathrm{mM}$ EDTA) was added. For pelleted cells or tissue samples, the protocol used was identical, with the exception that the volumes used were the halves of those above described. Tubes were left $24 \mathrm{~h}$ at RT, and DNA concentrations were measured using NanoDrop 2000 (Thermo). 


\section{Genotyping}

$G C L^{\text {floxed }}$ mice were genotyped by PCR. Forward and reverse oligonucleotides were, respectively, 5'-AAGTCGTGCTGCTTCATGTG-3' 5'ACGTAAACGGCCACAAGTTC-3', which generated a 200 bp band from the eGFP coding region, present in the construct. An internal control was used to detect false negatives using the endogenous snca gene. Its forward and reverse oligonucleotides were, respectively, 5'-ATCTGGTCCTTCTTGACAAAGC-3' and 5'AGAAGACCAAAGAGCAAGTGACA-3', which generated a 150 bp band. PCR conditions were: $3 \mathrm{~min}$ at $94^{\circ} \mathrm{C}, 35$ cycles of 1) $45 \mathrm{~s}$ at $\left.94{ }^{\circ} \mathrm{C}, 2\right) 45 \mathrm{~s}$ at $\left.55^{\circ} \mathrm{C}, 3\right) 45 \mathrm{~s}$ at $72{ }^{\circ} \mathrm{C}$ and a final step $10 \mathrm{~min}$ at $72{ }^{\circ} \mathrm{C}$. Final concentrations of PCR components were $0.2 \mathrm{mM}$ dNTPs mix (Roche), $0.5 \mu \mathrm{M}$ of eGFP primers (Sigma), $0.25 \mu \mathrm{M}$ of snca primers (Sigma), $0.008 \mathrm{U} / \mu \mathrm{l}$ of Taq polymerase (Biotools) and $1 \mathrm{X}$ reaction buffer with $\mathrm{MgCl}_{2}$. The total amount of DNA added was 50-100 ng.

CamKII $\alpha$-Cre transgene was detected by amplifying a 270 bp region of Cre recombinase by PCR. Forward and reverse oligonucleotides used were, respectively, 5'GCATTTCTGGGGATTGCTTA-3' and 5'-CCCGGCAAAACAGGTAGTTA-3'. An internal control was used to detect false negatives using the endogenous snca gene. Its forward and reverse oligonucleotides were, respectively, 5'ATCTGGTCCTTCTTGACAAAGC-3' ${ }^{\prime}$ and AGAAGACCAAAGAGCAAGTGACA-3', which generated a 150 bp band. PCR conditions were: $3 \mathrm{~min}$ at $94{ }^{\circ} \mathrm{C}, 35$ cycles of 1) $1 \mathrm{~min}$ at $\left.94{ }^{\circ} \mathrm{C}, 2\right) 1 \mathrm{~min}$ at $58{ }^{\circ} \mathrm{C}$, 3) 1 min at $72{ }^{\circ} \mathrm{C}$ and a final step $10 \mathrm{~min}$ at $72{ }^{\circ} \mathrm{C}$. Final concentrations of PCR components were: $0.2 \mathrm{mM}$ dNTPs mix (Roche), $0.5 \mu \mathrm{M}$ of Cre primers (Sigma), $0.25 \mu \mathrm{M}$ of snca primers (Sigma), $0.008 \mathrm{U} / \mu \mathrm{l}$ of Taq polymerase (Biotools) and $1 \mathrm{X}$ reaction buffer with $\mathrm{MgCl}_{2}$. The total amount of DNA added was 50-100 ng.

\section{Detection of recombination}

The recombination event was detected by PCR from pelleted cells or tissue samples. The non-recombined state was detected using the forward and reverse oligonucleotides, which were, respectively, 5'-CATCGAGCTGAAGGGCATC-3' and 5'CGGTGGGAGGTCTATATAAGCA-3', and which amplified a 900 bp band. The recombined state was detected using the forward and reverse oligonucleotides, which 
were, respectively, 5'-GGTCAGGGTGGTCACGAG-3' and 5'CGGTGGGAGGTCTATATAAGCA-3', and which amplified a 300 bp band. PCR conditions for both PCRs were: $3 \mathrm{~min}$ at $94{ }^{\circ} \mathrm{C}$, 35 cycles of 1) $1 \mathrm{~min}$ at $94{ }^{\circ} \mathrm{C}$, 2) $1 \mathrm{~min}$ at $55{ }^{\circ} \mathrm{C}$, 3) $1 \mathrm{~min}$ at $72{ }^{\circ} \mathrm{C}$ and a final step $10 \mathrm{~min}$ at $72{ }^{\circ} \mathrm{C}$. The final concentrations of PCR components were: $0.2 \mathrm{mM}$ dNTPs mix (Roche), $0.5 \mu \mathrm{M}$ of the appropriate oligonucleotides (Sigma), $0.008 \mathrm{U} / \mu \mathrm{l}$ of Taq polymerase (Biotools) and $1 \mathrm{X}$ reaction buffer with $\mathrm{MgCl}_{2}$. The total amount of DNA added was 50-100 ng.

\section{Gel electrophoresis}

Linearized vectors, excised fragments, as well as PCR products were run in a $0.8 \%, 1 \%$, 2\% and 3\% (w/v) agarose gels (Sigma), depending of the expected DNA size. Gels were pre-stained with MidoriGreen (1:20,000) and run in TAE buffer (200 $\mu \mathrm{M}$ Trizma-Base, $100 \mathrm{mM}$ Glacial Acetic acid, $\left.5 \mathrm{mM} \mathrm{Na} \mathrm{EDTA} \cdot 2 \mathrm{H}_{2} \mathrm{O}\right)$, using a $6 \mathrm{X}$ loading dye (10 mM Trizma-Base pH 7.6, 0.03\% Bromophenol blue, 0.03\% (v/v) Xylene cyanole, 60\% (v/v) Glycerol, $60 \mathrm{mM} \mathrm{Na} 2 \mathrm{EDTA} \cdot 2 \mathrm{H}_{2} 0$ ) for DNA input. Images were taken using Bio-Rad Chemidoc.

\section{MEF transfections and treatments}

Transfections of MEFs with plasmid vectors were performed using Lipofectamine2000 ${ }^{\mathrm{TM}}$ (Invitrogen), following the manufacturer' instructions. After $6 \mathrm{~h}$, fresh medium was added containing either $1 \mu \mathrm{M}$ 4-OH-Tamoxifen (TM) (Sigma) or vehicle (ethanol).

\section{Western blotting}

Cells were lysed in RIPA buffer (2\% sodium dodecylsulphate, 2 mM EDTA, 2 mM EGTA and $50 \mathrm{mM}$ Tris, $\mathrm{pH}$ 7.5), supplemented with phosphatase inhibitors (100 $\mu \mathrm{M}$ phenylmethylsulfonyl fluoride, $50 \mu \mathrm{g} / \mathrm{ml}$ antipapain, $50 \mu \mathrm{g} / \mathrm{ml}$ pepstatin, $50 \mu \mathrm{g} / \mathrm{ml}$ amastatin, $50 \mu \mathrm{g} / \mathrm{ml}$ leupeptin, $50 \mu \mathrm{g} / \mathrm{ml}$ bestatin, $1 \mathrm{mM}$ o-vanadate, $50 \mathrm{mM} \mathrm{NaF}$, and $50 \mu \mathrm{g} / \mathrm{ml}$ soybean trypsin inhibitor) and boiled for $5 \mathrm{~min}$. Extracts were centrifuged at 13,000xg for $5 \mathrm{~min}$ at $4^{\circ} \mathrm{C}$, and aliquots of lysates (50 $\mu \mathrm{g}$ protein) were subjected to sodium docedyl sulfate-polyacrylamide (SDS-PAGE) electrophoresis on 8\% acrylamide gel (MiniProtean ${ }^{\circledR}$, Bio-Rad) including Dual Colors ${ }^{\mathrm{TM}}$ (BioRad) as prestained protein ladder. The resolved proteins were transferred electrophoretically to nitrocellulose membranes (Hybond-ECL, Amersham Bioscience Europe GmbH). Membranes were 
blocked with 5\% (w/v) low-fat milk in $20 \mathrm{mM}$ Tris, $500 \mathrm{mM} \mathrm{NaCl}$, and $0.1 \%(\mathrm{w} / \mathrm{v})$ Tween 20, pH 7.5, for $1 \mathrm{~h}$. After blocking, membranes were immunoblotted with 1:2000 rabbit anti-GCL (catalytic subunit) (Abcam) and mouse anti-GAPDH (1:40000) primary antibodies, overnight at $4{ }^{\circ} \mathrm{C}$. After incubation with horseradish peroxidaseconjugated goat anti-rabbit IgG (1:10000 dilution, Pierce, Thermo Fischer Scientific) and/or goat anti-mouse IgG (1:10000 dilution, BioRad), membranes were immediately incubated with the enhanced chemiluminescence kit SuperSignal West Dura (Pierce, Thermo Scientific, Illinois, USA) for $5 \mathrm{~min}$, before exposure to Kodak XAR-5 film for 1-5 min, and the autoradiograms were scanned.

\section{Glutathione concentration determination}

Oxidised (GSSG) and total glutathione (GSx; GSx=GSH+2GSSG) was measured in MEFs. For tissues, only total glutathione was assessed. For MEFs, $1 \mathrm{ml}$ of 5 \% (w/v) 5sulfosalicylic acid (SSA) per $10^{6}$ cells was added. An equal volume of $\mathrm{NaOH} 0.1 \mathrm{M}$ was added to the same amount of cells for protein quantification. For tissue, $20 \mu \mathrm{l}$ of $5 \%$ (w/v) of SSA was added per mg of tissue, and diluted 1:5 for subsequent glutathione measurement. In all cases, samples were pelleted and transferred to a fresh tube. For oxidized glutathione (GSSG) determination, $60 \mu \mathrm{l}$ of sample or GSSG standard were incubated with $3.43 \mu \mathrm{l}$ of 2-vinylpiridine and $2.75 \mu \mathrm{l}$ of triethanolamine for $1 \mathrm{~h}$ at $4{ }^{\circ} \mathrm{C}$. This derivatisation reaction protects the sulfhydryl group forming a tioether, which does not react in the determination assay. Thus, only GSSG is measured in these samples. Reduced glutathione concentration (GSH) was calculated from the formula $\mathrm{GSx}=\mathrm{GSH}+2 \mathrm{GSSG}$, according to (Tietze, 1969). The assay uses $\mathrm{NADPH}\left(\mathrm{H}^{+}\right)$and glutathione reductase (GR) to reduce back the oxidised glutathione upon formation, a reaction that is coupled to the formation of TNB $\left(\lambda_{\max }=405 \mathrm{~nm}\right)$ from GSH and DTNB. In view that this is, therefore, a cycling reaction, the slope is registered over a 10 -min (20 iterations) period at $405 \mathrm{~nm}$. The rates of TNB formation in the samples were extrapolated to those obtained with GSSG standards (Sigma). For GSx, GSSG standards were used in the range of 0-70 $\mu \mathrm{M}$, whereas for GSSG, GSSG standards were used in the range $0-20 \mu \mathrm{M}$. The reaction composition consisted of $175 \mu \mathrm{l}$ of $0.33 \mathrm{mM}$ NADPH sodium salt prepared extemporarily in $\mathrm{NaE}$ buffer (143 mM sodium phosphate, $6.3 \mathrm{mM}$ EDTA, pH 7.5), $35 \mu \mathrm{l}$ of $\mathrm{H}_{2} \mathrm{O}, 25 \mu \mathrm{l}$ of $6 \mathrm{nM}$ DTNB (in NaE buffer), $10 \mu \mathrm{l}$ of sample or standard and $50 \mu \mathrm{l}$ of GR (4 U/ml for GSx or $20 \mathrm{U} / \mathrm{ml}$ for GSSG determinations). 


\section{$\mathrm{H}_{2} \mathrm{O}_{2}$ determination}

$\mathrm{H}_{2} \mathrm{O}_{2}$ assessment was performed in intact, seeded cells. $1.25 \times 10^{5}$ cells were incubated in $100 \mu \mathrm{M}$ AmplexRed probe (Invitrogen) in Krebs-Ringer phosphate buffer (145 mM $\mathrm{NaCl}, 5.7 \mathrm{mM} \mathrm{Na}_{2} \mathrm{PO}_{4}, 4.86 \mathrm{mM} \mathrm{KCl}, 0.54 \mathrm{mM} \mathrm{CaCl}_{2}, 1.22 \mathrm{mM} \mathrm{MgSO}_{4}$ and $5.5 \mathrm{mM}$ glucose), containing horseradish peroxidase $(0.5 \mathrm{U} / \mathrm{ml})$. Luminescence was recorded for $2 \mathrm{~h}$ at 30 min intervals using a Varioskan Flash (Thermo Scientific, Rockford, IL, USA) fluorimeter (excitation: $538 \mathrm{~nm}$, emission: $604 \mathrm{~nm}$ ), and the slopes were compared with those obtained with $\mathrm{H}_{2} \mathrm{O}_{2}(0-10 \mu \mathrm{M})$ for the calculations.

\section{Thiols concentration determination}

Cells seeded in 96-well plates at $2 \times 10^{5}$ cells $/ \mathrm{cm}^{2}$ were washed twice with PBS $\mathrm{pH} 7.4$, incubated with $98 \mu \mathrm{l}$ of SDS/EDTA buffer (SDS 2\% (w/v) in $80 \mathrm{mM}$ phosphate buffer $\mathrm{pH}$ 8, containing $1 \mathrm{mM}$ EDTA), and the absorbance was read at $412 \mathrm{~nm}$. Then, $2 \mu \mathrm{l}$ of freshly prepared DTNB (10 mM in 0.1mM phosphate buffer, $\mathrm{pH} 8$ ) was added and absorbance was read again after $20 \mathrm{~min}$. Glutathione standards were prepared in SDS/EDTA buffer. The absorbance at 0 min was subtracted from the absorbance at 20 min, and thiols concentrations were inferred from the glutathione standard curve.

\section{Protein determination}

Cells were lysed in $0.1 \mathrm{M} \mathrm{NaOH}$ and used for the determination of protein concentration by the BCA protein assay kit (Pierce), following the manufacturer's instructions. Bovine serum albumin was used as standard.

\section{Mice perfusion and immunohistochemistry}

Mice were deeply anesthetized by i.p. injection of a mixture (1:4) of xilacine hydrochloride and ketamine hydrochloride/chlorbutol (1 ml/kg of body weight). Mice were intra-aortically perfused with $0.9 \% \mathrm{NaCl}$, followed by $5 \mathrm{ml} / \mathrm{g}$ per body weight of paraformaldehyde (PFA, 4\% (w/v) in $0.1 \mathrm{M}$ phosphate buffer (PB) at $\mathrm{pH} 7.4$ ). After perfusion, brains were dissected out sagittally in two parts and post-fixed using PFA overnight at $4{ }^{\circ} \mathrm{C}$. Brain blocks were rinsed successively for $10 \mathrm{~min}, 30 \mathrm{~min}$, and $2 \mathrm{~h}$ with $0.1 \mathrm{M}$ PB solution and immersed in 10\%, 20\% and 30\% (w/v) sucrose in PB solution sequentially, until they sank. After cryoprotection, $30 \mu \mathrm{m}$-thick sagittal sections were obtained with a freezing-sliding cryostat (Leica). The sections were collected serially in a 12 well plate in $0.1 \mathrm{M} \mathrm{PB}$ and rinsed 3 times for $10 \mathrm{~min}$ in $0.1 \mathrm{M}$ PB and 
used for subsequent immunohistochemistry. The section-containing wells that were not used were kept in $0.05 \%$ sodium azide (w/v) in $0.1 \mathrm{M} \mathrm{PB}$ at $4^{\circ} \mathrm{C}$. For immunohistochemistry, sections were incubated sequentially in: (i) $5 \mathrm{mg} / \mathrm{ml}$ sodium borohydride in PB for 30 minutes (to remove aldehyde autofluorescence); (ii) appropriate mix of primary antibodies in $0.2 \%$ Triton X-100 and 5\% normal goat serum (Jackson) for $16-18 \mathrm{~h}$ at $4{ }^{\circ} \mathrm{C}$ in $0.1 \mathrm{M} \mathrm{PB}$; (iii) appropriate mix of conjugated secondary antibodies for $1 \mathrm{~h}$ at room temperature; and (iv) $0.5 \mu \mathrm{g} / \mathrm{ml}$ DAPI in PB for 10 minutes at room temperature. After each step, sections were carefully rinsed three times for $10 \mathrm{~min}$ in PB. Antibodies concentrations used in this study were: 1:200 mouse anti-CamKII $\alpha$ (Enzo), 1:1000 rabbit anti-CamKII $\alpha$ (Abcam), 1:1000 rabbit anti-nitrotyrosine (Sigma), 1:200 mouse anti-GSH (Arbor Assays), 1:400 rabbit anti-GCL (Abcam), 1:500 Alexa 488-conjugated goat anti-rabbit and 1:500 Alexa 594-conjugated goat anti-mouse (Molecular Probes) 1:500 Cy5 goat anti-mouse (Jackson). Sections were examined with epifluorescence and appropriated filters sets using a Nikon Inverted microscope (Eclipse Ti-E) equipped with a pre-centered fiber illuminator (Nikon, Intensilight C-HGFI) and B/W CCD digital camera (Hamamatsu ORCAER, Hamamatsu), or a confocal microscope (TCS SP1; Leica) using sequential acquisition for Alexa's 488 and 594 fluorophores.

\section{Nissl staining}

Sections of $30 \mu \mathrm{m}$ thick, obtained as previously described, were mounted in slides and left to dry overnight at RT. Slides were immerse in a Coplin jar in absolute ethanol and chlorophorm mix (1:1) overnight, and sequentially immersed for 5 min each in a battery of ethanol solutions at decreasing concentrations down to distilled water for rehydratation, Nissl dye (cresyl violet $0.1 \%(\mathrm{w} / \mathrm{v}), 0.3 \%(\mathrm{v} / \mathrm{v})$ glacial acetic in water) at $37{ }^{\circ} \mathrm{C}$, washed under tap water, distilled water, 96\% ethanol (until Purkinje cells are visualized), absolute ethanol (twice), xylol (twice), and mounted in Dentellan solution (Sigma).

\section{Carbonyl groups detection and proteomics analysis}

This was performed at the Proteomics Service of the University of Lleida. Carbonyl oxidation was detected in SDS-PAGE gels. Brain samples were incubated in $20 \mathrm{mM}$ Tris-HCl, $\mathrm{pH}$ 7.5, plus a cocktail of protease inhibitors (Roche) and disaggregated mechanically using an insulin syringe. SDS was added to a final concentration of $2 \%$ 
(v/v) and the mix was heated at $95{ }^{\circ} \mathrm{C}$ for $3 \mathrm{~min}$, centrifuged at 14,000 rpm for $5 \mathrm{~min}$, and the supernatant was transferred to a fresh tube. Protein concentration was determined and samples were derivatized using the Bodipy FL-hydrazide (Bodipy-Hz), as previously described (Tamarit et al., 2012). Extracts were loaded in acrylamide gels ( $9 \%$ for running and 5\% for stacking) and run in the Miniprotean II (Bio-Rad) electrophoresis equipment. Gels images were taken by a ChemiDoc XRS System (BioRad), and carbonyls were detected with a Cy2 filter (680BP). Gels were fixed with 40 $\%$ ethanol (v/v) plus 10\% acetic acid (v/v) overnight, and incubated with flamingo dye for $3 \mathrm{~h}$ for total protein staining, and detected with the flamingo filter (605BP).

\section{Motor balance and coordination measurements}

Motor balance and coordination was analyzed using the Rotarod test (Scheme 4) every eight weeks. Each test took three consecutive days, in which three trials were performed per day. In addition, mice were previously trained during three consecutive days, two weeks before the first test was performed. All determinations were carried out at the same time of the day. For the test, mice were allowed to stay for $300 \mathrm{~s}$ on an accelerating rotating bar (5 lines per Rotarod apparatus, Model 47600, Ugo Basile). The continuous accelerating rotation speed ranged from 4 to $40 \mathrm{rpm}$, with a net 4-rpm rise every $30 \mathrm{~s}$, reaching the final speed at $270 \mathrm{~s}$. Latency to fall was measured during this period, annotating the time the animal stayed on the rotating rod. Data from tests in which animals completed 3 turns without walking were disregarded.

\section{Assessment of cognitive performance}

These tests were always performed in the same time slot ( $2 \mathrm{pm}-8 \mathrm{pm})$, and animals were left to acclimatize in the room for not less than 15 min. Tracking of animals were carried out once at a time, cleaning carefully the apparatus with an $70 \%$ ethanol solution between animals to remove any odor cues. For the Open Field and Hole-Board tests, an ANY-box core was used (Scheme 5.a and 6.a). This core contained a light grey base and an adjustable perpendicular stick holding a camera and an infrared photo-beam array to track the animal movement and to detect rearing behaviour, respectively. Mouse movements were tracked with the ANY-maze software and the AMi-maze interface to register all parameters described below.

\section{Open Field Test}


The Open Field test measures a combination of locomotor activity, exploratory drive, neophobia, agoraphobia and other aspects of anxiety or fear in mice. The output of the various interacting drives and influences is ambulation, which is the only directly measurable parameter. The Open Field test (Stoelting) consists of the ANY-box core (Scheme 5.a) and a $40 \mathrm{~cm}$ x $40 \mathrm{~cm}$ x $35 \mathrm{~cm}$ (w, d, h) black infrared transparent Perspex insert (Scheme 5.b). The Open Field arena was divided in the following zones: a, border, with $8 \mathrm{~cm}$ wide; $\mathbf{b}$, center, consisting of $16 \%$ of total arena, and $\mathbf{c}$, intermediate zone, which occupies the remaining zone left (Figure 5.c). The duration of the test was 30 min. Distance travelled and time spent in each zone was measured.

\section{$\underline{\text { Hole-Board Test }}$}

Head dipping (nose pokes) on a Hole-Board was used as an indicator of exploratory tendencies and locomotor activity-independent anxiety. The Hole-Board test (Stoelting) consists of the ANY-box core (Scheme 6.a) with a $40 \mathrm{~cm} \mathrm{x} 40 \mathrm{~cm}(\mathrm{w}, \mathrm{d})$ raised base with 16 holes ( $3 \mathrm{~cm}$ diameter each) arranged in a $4 \mathrm{x} 4$ grid raised $10 \mathrm{~cm}$ above the floor (Scheme 6.b), fitted snugly inside and a black Perspex insert infrared transparent with the dimensions $40 \mathrm{~cm} \times 40 \mathrm{~cm} \times 35 \mathrm{~cm}(\mathrm{w}, \mathrm{d}, \mathrm{h})$. The test duration was $5 \mathrm{~min}$. The total number of nose pokes was measured.

\section{$\underline{\text { Radial Arm Maze }}$}

The Radial Arm Maze test was used to determine spatially learning and memory without any food restriction/food reward. A cued version was used instead taking advantage of the exploratory nature of mice that drives it to explore unvisited arms. The apparatus consists of eight equidistantly spaced arms radially placed from a small circular central platform (Stoelting). Each arm measures $5 \mathrm{~cm} \mathrm{x} 35 \mathrm{~cm}$ x $9 \mathrm{~cm}(\mathrm{w}, \mathrm{l}, \mathrm{h})$, it is removable, and it fits in the slotted, light grey base (Scheme 7.a). Geometric figures were placed in the arms as spatial cues, and the apparatus was sub-divided in the following zones (in this order, anticlockwise): 1) Empty arm: this arm has no figures attached to the wall; this is the Start arm; 2) Diamond arm: containing 13 diamonds (6 per wall, plus one more at the end of the arm); 3) Circle arm: containing 11 circles (5 per wall, plus one more at the end of the arm); 4) Square arm: containing 11 squares (5 per wall, plus one more at the end of the arm); 5) Cross arm: containing 9 crosses (4 per wall, plus one more at the end of the arm); 6) Triangle arm: containing 13 triangles (6 per wall plus, plus one more at the end of the arm); 7) Star arm: containing 11 jagged 
circles (5 per wall, plus one more at the end of the arm); and 8) Rectangle arm: containing 11 rectangles (5 per wall, plus one more at the end of the arm). A "nonreturn” sequence (Scheme 7.b) was programmed in the software in order to count the number of non-return explorations, i.e. all arms visited without repeating a previously visited arm. The test duration was $15 \mathrm{~min}$. The number "non-return” sequences, and the number of broken sequences (errors) were measured

\section{Statistical analysis}

All measurements in cell culture were carried out, at least, in triplicate, and the results are expressed as the mean \pm s.e.m. values from at least three different culture preparations. For the behavioral experiments, we used at least six animals per condition. Statistical analysis of the results was performed by one-way analysis of variance, followed by the least significant difference multiple range test or, for comparisons between two groups of values, by the Student's t-test. In all cases, $\mathrm{p}<0.05$ was considered significant.

\section{Ethical statement regarding the use of animals}

All animals used in this wok were obtained from the Animal Experimentation Unit of the University of Salamanca in accordance with Spanish legislation (RD 1201/2005) under license from the Spanish Ministry of Economy and Competitiveness (MINECO). Protocols involving animals were approved by the Bioethics Committee of the University of Salamanca. 


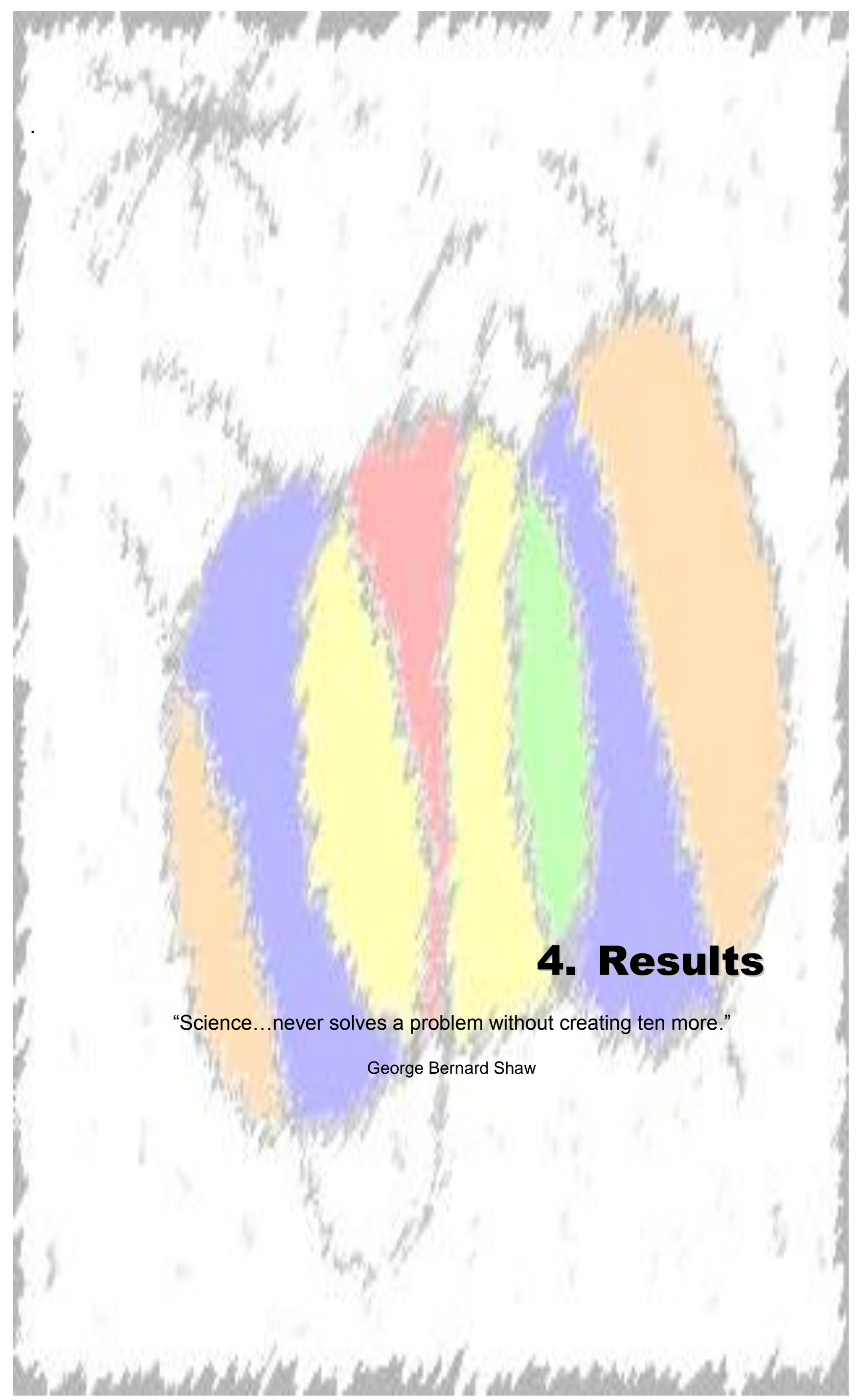


Generation of the shGCL $L^{\text {floxed }}$ construct

shGCL $L^{\text {floxed }}$ construct was achieved in eleven phases of cloning and subcloning, using pre-existing elements from various commercially available plasmids and sequences introduced as chemically synthesized and annealed oligonucleotides. Each cloning step generated a new vector denoted as $\mathrm{pPI}$ to $\mathrm{pPXI}$ in consecutive roman numbering. Plasmid pPI was obtained from pIRES2-eGFP (5.3 kb) modified to contain the Lox2272sense sequence at the 3' end of its CMV promoter. RE digestion with NheI and XmaI allowed plasmid linearization (Figure 1.a) to compatible-ends designed Lox2272sense. NheI RE site intentionally disappeared due to Lox2272 sequence designed, which allowed clone selection due to the small fragment size inserted (Figure 1.b). The resulting plasmid weighed $5.3 \mathrm{~kb}$.

Plasmid pPII was generated from commercially available pSuper.neo-gfp (5.4 kb), which was modified to contain the LoxPsense sequence in antisense orientation at the 3' end of its $\mathrm{H} 1$ promoter. Linearization of the vector (Figure 1.c) using BglII and XhoI $\mathrm{RE}$ allowed subsequent ligation of LoxPsense, due to its designed compatible ends that resulted in the intentional loss of those RE sites useful for clone identification (Figure 1.d). It also introduced the SalI RE and a second XmaI RE site used in subsequent cloning steps. The resulting $p P I I$ weighed 5,447 bp.

Plasmid pPIII was generated from pPII that was modified to contain Adaptor1 at the 5' end of $\mathrm{H} 1$ promoter. pPII was linearized (Figure 2.a) with REs EcoRI and NotI, a fragment of $\sim 2,200 \mathrm{bp}$ was excised and the $\sim 3,000$ bp vector backbone was purified to subsequent ligation with Adaptor1. The compatible-ends designed Adaptor1 ligation resulted in the intentional loss of EcoRI (Figure 2.b) and the introduction of MluI site, useful for subsequent cloning steps. The resulting $p P I I I$ weighed 3,183 pb.

Plasmid pPIV was generated from pPIII that was modified to contain the neomycin resistance gene in antisense orientation to the 3' end of LoxPsense. pPIII was linearized (Figure 2.d) with REs SalI and XmaI. The neomycin resistance gene was excised form the commercially available pcDNA3.1(+) vector $(5.4 \mathrm{~Kb})$, performing a double digestion (Figure 2.c) with REs SalI and XmaI. Both linearized pPIII, and neomycin 
resistance fragment were ligated together to obtain $\mathrm{pPIV}$, with a final weight of 4,349 bp.

Plasmid pPV was generated from peGFP-C1 commercially available plasmid (4.7 Kb), which multiple cloning site (MCS) was excised using the REs BglII and BamHI (Figure 3.a), and then self-ligated, resulting in the loss of both REs (Figure 3.b). Plasmid pPV had a resulting weight of $4.6 \mathrm{~kb}$.

Plasmid pPVI was generated using the plasmid $\mathrm{pPV}$ that was modified to contain the Lox2272antisense sequence in sense orientation to the 5' end of the sequence codifying eGFP. The linearization of pPV (Figure 3.c) using REs AgeI and NheI allowed the cloning of the compatible-ends designed Lox2272antisense sequence, which also was designed to loss the AgeI RE site (Figure 3.d). The resulting pPVI plasmid weighed 4.7 $\mathrm{kb}$.

Plasmid pPVII was generated from pPVI that was modified to contain the LoxPantisense in sense orientation to the 5' end of Lox2272antisense. The linearization of pPVI (Figure 4.a) using REs AseI and NheI allowed the subsequent ligation with the compatible-end designed LoxPantisense, also designed to loss the NheI (Figure 4.b) site and the introduction of new RE sites BglII, HindIII and Not1, useful in subsequent cloning steps. The resulting pPVII had a final weight of $4.2 \mathrm{~kb}$.

Plasmid pPVIII was developed with the aim of fusing: 1) eGFP, Lox2272antisens, and LoxP antisense, belonging to the pPVII vector between the REs NotI and MluI, and 2) the neomicin resistance gene and $\mathrm{H} 1$ promoter sequences, belonging to the plasmid pPIV between REs XmaI and MluI. To do so, pPIV was linearized (Figure 4.c) with REs NotI and MluI and ligated to a $~ 1,200$ bp fragment excised with the same REs from vector pPVII (Figure 4.d). The resulting vector had a weight of 5,426 bp.

Plasmid pPIX was generated with the aim of fusing: 1) the LoxPsense, H1, eGFP, Lox2272antisense and LoxPantisense sequences, which were present in the previously generated pPVIII between the REs XmaI and NotI, and 2) the CMV and Lox2272sense sequences contained in plasmid pPI between the same REs. Linearized pPI (Figure 5.a) with REs NotI and XmaI resulted in a $4 \mathrm{~kb}$ vector backbone that was ligated with a 
2,500 bp fragment from the pPVIII excised with the same REs (Figure 5.b). The resulting plasmid weighed $6.5 \mathrm{~kb}$. This plasmid contains unique BglII and HindIII restriction sites, which makes it useful to clone any shRNA.

Plasmid $\mathrm{pP} X$ was designed to excise Neomycin cassette from plasmid $\mathrm{pPIX}$ in order to use it for the microinjections. Neomycin was deleted digesting pPIX with REs XmaI and SalI (Figure 5.c) and self-ligating the $~ 5,400$ bp vector backbone. Prior to ligation, the cohesive ends generated by both enzymes were filled to produce blunt end with Klenow enzyme. Thus, XmaI and SalI RE sites were lost (Figure 5.d). This plasmid contains unique BglII and HindIII restriction sites to clone any shRNA (Figure 6.c).

Plasmid pPXI was obtained from $\mathrm{pP} X$ previously digested with the unique REs sites, BglII and HindIII (Figure 6.a). The compatible-end designed (as in pSuper technology) shGCL was ligated to the linearized vector, losing the BglII RE site (Figure 6.b). The final shGCL $L^{\text {floxed }}$ construct representation can be observed in Figure 6.d. This configuration is the non-recombined state.

\section{Generation shGCL ${ }^{\text {floxed }}$ mice}

pPXI was digested with AflII and AseI to excise the whole construct without any other bacterial sequence and leaving over 200 nt extra for hypothetical endonuclease degradation upon oocyte microinjection. The 2,200 bp size fragment (Figure 7.a) was purified and resuspended in microinjection buffer and quantified using Nanodrop 2000. Pre-fertilized oocytes from the hybrid background C57B6/CBA F1 were microinjected with the shGCL $L^{\text {floxed }}$ linearized construction. This background was chosen due to high response to super-ovulation and high puncture resistance. Punctured oocytes survivors that evolved to two-cell stage were implanted into CD1 pseudo-pregnant mice. Three initial founders or sublines were identified by PCR for the $s h G C L^{\text {floxed }}$ construct and where called $s h G C L^{\text {floxed }}-1$, shGCL $L^{\text {floxed }}-2$ and $s h G C L^{\text {floxed }}-3$ (Figure 7.d). This founder were then backcrossed with $\mathrm{C} 57 \mathrm{Bl} / 6 \mathrm{~J}$ wild type mice. $\mathrm{C} 57 \mathrm{Bl} / 6 \mathrm{~J}$ background homogeneity was increased in each generation (as described in Scheme 8). F3 mice were used for MEFs generation. For in vivo studies hemizygous F4 mice were crossed with homozygous CamKII $\alpha$-Cre line. Progeny genotype was assessed performing two different PCRs for the shGCL floxed construct and Cre transgene (Figure 7.b and 7.c). The 
possible genotypes were: control [CamKII $\alpha-C r e(+/-) / \operatorname{shGCL}(-/-)]$ and knockdown [CamKII $\alpha-C r e(+/-) / \operatorname{shGCL}(+/-)]$.

Southern analysis where performed digesting genomic DNA with HindIII and using eGFP as probe to: 1) visualize the expected size of the transgene for correct integration; 2) determine the number of integration sites; and 3) to estimate, between sublines, the number of copies of the transgene integrated in tandem. As shown in figure 8.a shGCL $L^{\text {floxed }}-1$ exhibited a correct band size for transgene corresponding to excised tandem copies. A unique integration site can be observed from generation 2 onwards. shGCL $L^{\text {floxed }}$-2 (Figure 8.b) mice showed no band for the transgene. Unique copy integrations are not usual. Besides, it does not remain clear if an integration site really exists. Initial identification was performed with PCR which could give false positives. Further analysis is required; therefore no further experiments have been performed in this line. In shGCL $L^{\text {floxed }}-3$ mice (Figure 8.c), up to three integration sites were detected in F1 generation, which were segregated upon C57BL/6J backcrossing. F4 mice used for this work had an only integration site of the transgene (lanes 4 and 6). Additionally, it appears that $s h G C L^{\text {floxed }}-3$ mice present more copies of the transgene than $s h G C L^{\text {floxed }}-1$, which could influence in the ability to knockdown more efficiently GCL protein.

In the meantime, shGCL ${ }^{\text {floxed }}$ mice were successively backcrossed with $\mathrm{C} 57 \mathrm{Bl} / 6 \mathrm{~J}$ and, at the time this Thesis is being written, they achieved $s h G C L^{\text {floxed }}-3$ subline has achieved a congenic state at 10 generations (F10), shGCL $L^{\text {floxed }}-1$ has reached 8 generations (F8) and shGCL $L^{\text {floxed }}-2$ is in $\mathrm{F} 4$ being the more delayed.

\section{Redox status of shGCL ${ }^{\text {floxed }}$ Mouse Embrionary Fibroblast (MEFs)}

MEFs from $s h G C L^{\text {floxed }}-3$ mice were obtained in order to validate the strategy implemented. All measurements required transfection with plasmid pCMV-CreER ${ }^{\mathrm{TM}}$ and/or the empty vector. Six hours after transfection with Lipofectamine2000, using the manufacturer' instructions, fresh medium was added to the cells in the absence (vehicle) or presence of $1 \mu \mathrm{M}$ 4-hydroxy-tamoxifen (TM) to allow Cre recombinase translocation to the nucleus and subsequent recombination. The correct functioning of the construct was analysed by PCR, which detected both the recombined and the non-recombined states (Figure 9.a). Robust bands, corresponding to the non-recombined status $(\sim 1,000$ bp), were observed in MEFs transfected with the empty vector, whereas much weaker 
bands were observed in pCMV-CreER ${ }^{\mathrm{TM}}$-transfected cells. TM-treated pCMV$\mathrm{CreER}^{\mathrm{TM}}$-transfected cells showed the weakest band. A robust band corresponding to the recombined status ( $\sim 300 \mathrm{bp}$ ) was observed in TM treated CreER ${ }^{\mathrm{TM}}$-transfected cells, whereas a very weak band was observed in vehicle-treated CreER ${ }^{\mathrm{TM}}$-transfected cells (Figure 9.a). As revealed by western blot analysis using anti-GCL, shGCL floxed $M E F s$ transfected with pCMV-CreER ${ }^{\mathrm{TM}}, 48 \mathrm{~h}$ and $72 \mathrm{~h}$ post-transfection (42 h and $66 \mathrm{~h}$ after TM addition, respectively) showed a progressive decrease in GCL protein when compared with controls (Figure 9.b). Next, $\mathrm{H}_{2} \mathrm{O}_{2}$ and total thiols were assessed $24 \mathrm{~h}$ after TM addition (or vehicle) in MEFs transfected with pCMV-CreER ${ }^{\mathrm{TM}}$ or empty vector. As shown in Figs. 10.a and 10.b, $\mathrm{H}_{2} \mathrm{O}_{2}$ and total thiols decreased in MEFs transfected with pCMV-CreER ${ }^{\mathrm{TM}}$ by $\mathrm{TM}$ treatment. Total glutathione (reduced plus oxidized) concentration was decreased (Figure 10.c) by transfection with pCMV$\mathrm{CreER}^{\mathrm{TM}}$, regardless of the absence or the presence of TM; however, the presence of TM further decreased total glutathione concentration. When oxidized and reduced glutathione were discriminated, and increase in oxidized glutathione was shown only when cells transfected with pCMV-CreER ${ }^{\mathrm{TM}}$ (Figure 10.d) were incubated with TM. Reduced glutathione was decreased in $\mathrm{PCMV}-\mathrm{CreER}^{\mathrm{TM}}$ - transfected cells regardless of the absence or presence of TM; however, the presence of TM further decreased reduced glutathione concentration and increased oxidized glutathione (Figure 10.d).

\section{Behavioural characterization of $s h G C L^{\text {floxed }}$ mouse lines.}

In order to see if $s h G C L^{\text {floxed }}$ presented per se any functional impairment due to ramdon integration sites of the transgenes, F4 mice sublines $s h G C L^{\text {floxed }}-1$ and $s h G C L^{\text {floxed }}-3$ were mated with C57BL/6J wild type mice and its offspring was subjected to behavioural tests. Rotarod test showed normal motor and balance coordination in mice aged 9-33 weeks for both shGCL $L^{\text {floxed }}-1$ (Figure 11) and $s h G C L^{\text {floxed }}-3$ (Figure 14) mice. The Open Field test revealed ambiguous fear/anxiety levels for 11-week-old male shGCL $L^{\text {floxed }}-1$ mice as the they travelled more distance in the border zone (Figure 12.a) but no differnces were shown in the time spent in each zone (Figure 12.b). Additionally, the Hole-board showed no differences in 11-27 weeks old mice (Figure 13), when the number of nose pokes were measured. For shGCL $L^{\text {floxed }}-3$ mice, both the Open Field (Figure 15) and Hole-board (Figure 16) tests showed no significative differences for fear/anxiety levels. 


\section{Behavioural characterization of CamKIIa-Cre/shGCL $L^{\text {floxed }}-1$ mice.}

For all behavioural tests we used the genotypes CamKII $\alpha$-Cre(+/-)/shGCL(-/-) (control) and CamKII $\alpha-C r e(+/-) / \operatorname{shGCL}(+/-)$ (knockdown). The data are either displayed by genotype $(n \geq 12)$ or by sex and genotype $(n \geq 6)$. Motor and balance coordination, assessed by the Rotarod test, showed to no significative impairement in the knockdown mice 9-33 weeks old, either grouped by genotype (Figure 17.a), or by sex and genotype (Figure 17.b). Fear/anxiety was determined both by the Open Field test and the HoleBoard test. Fear/anxiety behaviour remained ambiguous, in a similar fashion as in shGCL $L^{\text {floxed }}-1$ (previously described), as the Open Field showed no significative differences in the distance travelled in each zone (Figure 18.a), but $s h G C L^{\text {floxed }}-1$ spent less time in the centre zone of the arena than controls (Figure 18.b). However, the number of nose pokes, as assessed in the Hole-Board test (Figure 19), revealed no significative decrease in mice aged 11-27 weeks.

\section{Biochemical characterization of the CamKII $\alpha-C r e / s h G C L^{\text {floxed }}-3$ mice.}

To explore the effect of GCL knockdown in neurons, shGCL $L^{\text {floxed }}-3$ mice were crossed with CamKII $\alpha$-Cre mice, which express Cre recombinase in postnatal day 14-21 onwards mainly in the hippocampal neurons and in the forebrain in a scattered way. Brain tissue was extracted from 40 weeks-old mice of the genotypes CamKII $\alpha$-Cre $(+/-$ )/shGCL(-/-) (control), and CamKII $\alpha-C r e(+/-) / \operatorname{shGCL(+/-)~(knockdown).~The~brain~was~}$ dissected into cerebellum (Cb), striatum (Str), hippocampus (Hip) and prefrontal cortex (PCx). DNA extracted from hippocampal tissue was subjected to PCR for the detection of the non-recombined and the recombined construct (Figure 20). The band corresponding to the no recombined status $(\sim 1,000 \mathrm{pb})$ was detected in control, but not in knockdown mice. As shown in Figure 10 (right panel), the band corresponding to the recombined status ( $\sim 300 \mathrm{pb}$ ) was observed in knockdown, but not in control mice. Next, total glutathione (reduced plus oxidized) was measured in whole brain areas extracts (therefore containing a mixture of all brain cell types). As shown in Figure 21, no differences in total glutathione concentration were found between control and knockdown groups in any of the areas determined. Noticeably, total glutathione concentration was found to be significantly lower in the striatum of these mice regardless the genotype- when compared with the rest of the brain areas analysed (Figure 21). Brain samples, collected in the same way as above, were subjected to oxidized protein carbonyls detection (Figure 22, upper panel), and total protein 
abundance determination (Figure 22, lower panel) in females and males. As therein shown, the hippocampi of female knockdown females, and the hippocampi and striatum of knockdown males show higher carbonyls oxidation than their respective controls.

\section{Immunohistochemical characterization of the CamKII $\alpha-C r e / s h G C L^{\text {floxed }}$ mice.}

Sections of $30 \mu \mathrm{m}$ thick were subjected to several histochemical and immunohistochemical analyses. Hippocampal microphotographs of brain tissue from 40 week-old male mice were performed for CamKIIa-Cre(+/-)/shGCL(-/-) (control) and CamKIIa-Cre(+/-)/shGCL(+/-) (knockdown) mice. Nissl staining revealed no gross differences in the cytoarchitecture or layer thickness (Figure 23). Next, immunostaining was performed to detect changes in the redox status, as an index of oxidative stress marker. Confocal images were taken to detect co-localization and to perform sequential acquisition in order to discriminate fluorophore fluorescences (Alexa 488 and Alexa 594). At the time of writing this Thesis, the quantification of all images is yet incomplete, thus the images shown are to be considered in a qualitative fashion. For GCL staining (Figure 24), no major differences between control males and knockdown males were detected, likely due to the previously reported low detectable levels of GCL protein in the brain (Godoy et al., 2011). As revealed by the anti-GSH antibody (Figure 25), knockdown males appear to have less glutathionylated proteins. 3-Nitro-tyrosine staining (Figure 26) revealed a higher level of nitrotyrosination in knockdown males when compares with control males. In all cases, dense spots appeared that co-localized neatly with the oxidative stress markers 3-nitro-tyrosine and GSH. Their appearance seems to correspond to vesicular localization or aggregated proteins. Interestingly, CamKII $\alpha$ staining -which was performed with the aim to detect co-localizationrevealed increased levels of CamKII $\alpha$ protein in the knockdown males when compared with the control males (Figs. 24 and 26). It should be noticed, however, that this effect is hard to see with the image shown in Figure 24. In this context, it should be noted that the fluorophore used was different in both experiments, being Cy5 for the former and Alexa 594 for the latter. This difference appears to be mainly due to the phosphorylated form of CamKII $\alpha$, as judged by the results shown in Fig 25.

\section{Behavioural characterization of the CamKII $\alpha-C r e / s h G C L^{\text {floxed }}$ mice.}

For all behavioural tests we used the genotypes CamKII $\alpha$-Cre(+/-)/shGCL(-/-) (control) and CamKII $\alpha-C r e(+/-) / \operatorname{shGCL}(+/-)$ (knockdown). The data are either displayed by 
genotype $(n \geq 12)$ or by sex and genotype $(n \geq 6)$. Motor and balance coordination, assessed by the Rotarod test, showed to be impaired in the knockdown mice from 25 weeks old onwards (Figure 27.a), and this was mainly contributed by the bad performance of males (Figure 27.b). Fear/anxiety was determined both by the Open Field test and the Hole-Board test. No differences were observed when the statistics were performed sex-independently (data not shown). However, when sex was taken as a variable, knockdown females travelled less distance (Figure 28.a) and spent less time in the centre zone of the arena than controls (Figure 28.b), indicating more fear/anxiety in the formers. The number of nose pokes, as assessed in the Hole-Board test (Figure 29), revealed a decrease of nose pokes in 19-week-old knockdown females when compared with the control, indicating more anxiety/fear in the formers. Finally, spatial memory was assessed using the Radial Arm Maze test (Figure 30). At the light of the data obtained by determining the performances/total mice ratio (left panel) and the number of errors committed (right panel), control males performed better the task than control females; however, this ability of the males was impaired in the knockdown group. 


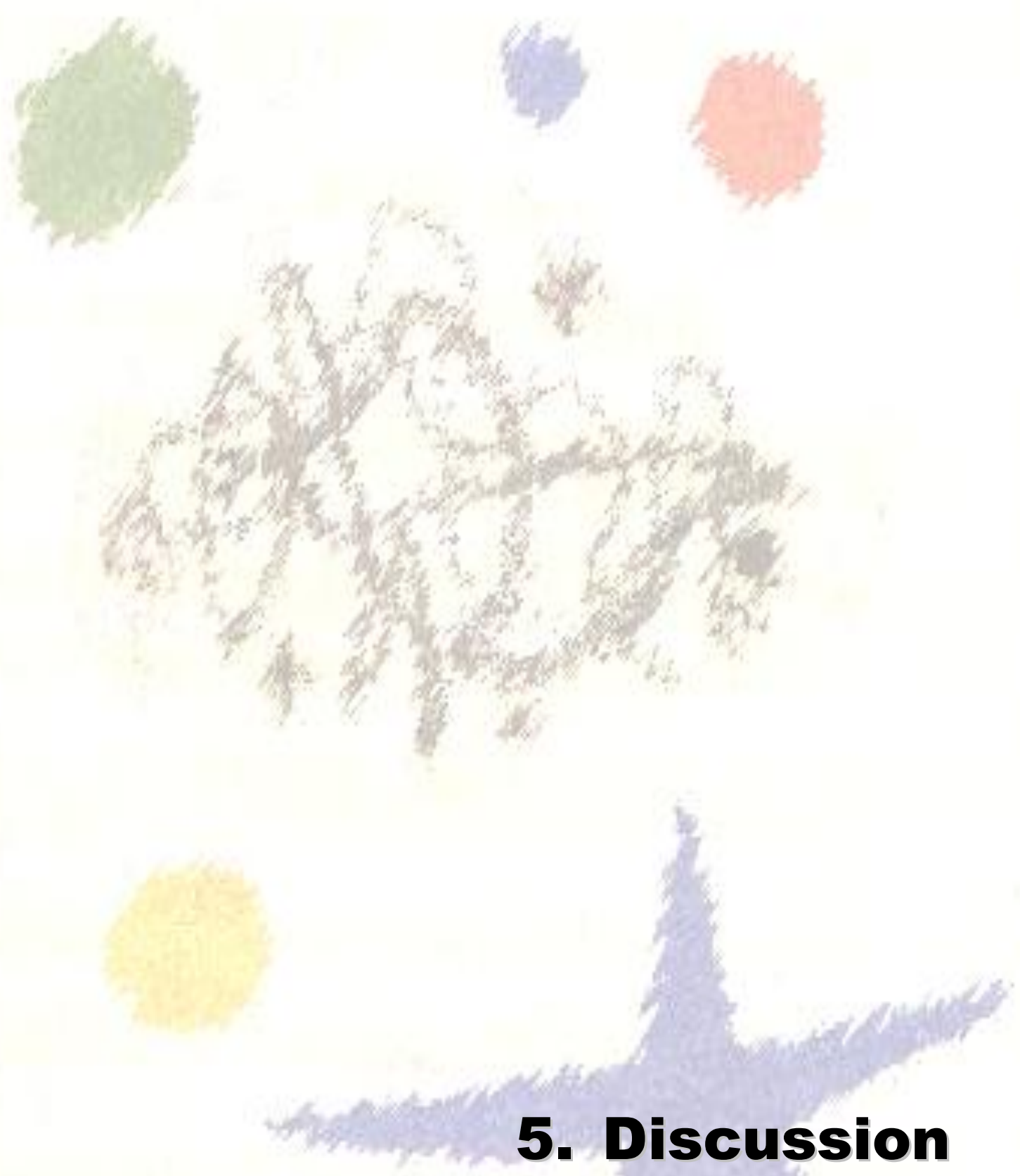

"If you are not part of the solution, you're part of the precipitate" Henry J. Tillman. 
Here, we have designed and generated a new tool to knockdown any gene, in a tissue specific and time-controlled manner, based on the Cre-LoxP strategy, a technique that revolutionized the analysis of the genetic expression in mice (Nagy, 2000). Our tool is useful for any tissue, and circumvents the classical difficulties previously found when addressing brain-specific genetic manipulations. Thus, former strategies and attempts relied on doxycycline inducible systems, which hardly cross the blood brain barrier (BBB) (Branda and Dymecki, 2004; Chinta et al., 2007). Our induction system, in contrast, relies on a Cre recombinase that is sensitive to tamoxifen, a compound that is able to penetrate the BBB (Danielian et al., 1993). In addition, the drug administration that is required to promote recombination is discrete (Hirrlinger et al., 2006), thus minimizing possible unwanted side effects. At the time this work began, a somehow similar shRNA-based inducible technology, also using the Cre-LoxP system, was reported (Fritsch et al., 2004). However, we disregarded the use of such a construct conformation for our aims because of its possible off-target effects. Thus, that shRNA construct consisted of an shRNA that was interrupted by a floxed neomycin cassette, to be excised upon a Cre recombination event. Such an element disposition does not prevent the $\mathrm{H} 1$ promoter from transcribing an alternative shRNA, with could exhibit off-target effects that varies for each individual shRNA cloned. Our construct, in contrast, contains a $\mathrm{H} 1$ promoter transcription end signal placed immediately after the H1 promoter in antisense orientation, thus preventing the shRNA synthesis in the nonrecombined state. Additionally, our strategy is versatile, as it only requires a straightforward shRNA cloning step between BglII and HindIII restriction sites, as it happens with the widely used pSuper technology (Oligoengine).

GCL knockout (KO) mice have been described (Dalton et al., 2000; Shi et al., 2000); GCL, catalytic subunit, KO homozygous mice are not viable beyond embryonic day $8^{\text {th }}$, and the heterozygous ones display an array of compensative mechanisms that preclude from fully understanding the specific role played by GCL in the phenotype; in addition, that GCL KO model is not tissue-specific or temporally-controlled. We decided to implement shRNA technology, instead of the conditional knock-out one, as we believe it could better resemble pathophysiological situations. In fact, mild GCL deficiency has been shown to occur by inducing specific mutations in the coding region of the GCL, catalytic subunit, gene (Dalton et al., 2004). Another advantage of the shRNA strategy 
over the $\mathrm{KO}$ one is the easier methodology; homozygosis is not required for an efficient shRNA action, whereas in general, the KO often requires homozygosis in view that the heterozygous mice show mild phenotypes, if any. During the course of progress of our shGCL ${ }^{\text {floxed }}$ mouse generation and characterization, a report showing inducible GCL alterations in dopaminergic neurons appeared (Chinta et al., 2007). That system relies on a very poor doxycycline induction, which requires administration of the drug for the whole duration of the experiment. Most importantly, the approach that those authors implemented to knockdown GCL was the classical full-length GCL antisense cDNA, which is highly unreliable in view of the numerous possible off-target effects. Instead, we selected a highly specific shRNA sequence based on well-contrasted rational criteria (Birmingham et al., 2007; Naito and Ui-Tei, 2012; Pei and Tuschl, 2006) previously demonstrated to be efficient and specific in primary cultured neurons (Diaz-Hernandez et al., 2005).

shGCL $L^{\text {floxed }}$ construct effectively recombines itself upon Cre recombinase activity, as demonstrated in cultured MEFs and in vivo. The slight recombination event observed in MEFs transfected with pCMV-CreER ${ }^{\mathrm{TM}}$, in the absence of tamoxifen, is probably due to the high-copy number inserted, as well as to serum-containing estradiol in the culture medium. CreER ${ }^{\mathrm{TM}}$ is sequestered in the cytosol by Hsp90 chaperon, and it translocates to the nucleus upon relatively high tamoxifen concentrations; thus, $\mathrm{CreER}^{\mathrm{TM}}$ is normally insensitive to physiological concentrations of estradiol (Danielian et al., 1998; Mattioni et al., 1994). However, the capacity of Hsp90 to sequester high amounts of $\mathrm{CreER}^{\mathrm{TM}}$-such as those present when over-expressing $\mathrm{pCMV}^{-\mathrm{CreER}}{ }^{\mathrm{TM}}$-, together with the presence of excessive estradiol concentrations, could account for the slight "leakage” phenomenon. In vivo, shGCL ${ }^{\text {floxed }}$ construct efficiently recombined when the shGCL $L^{\text {floxed }}$ mice was crossed with the CamKII $\alpha$-Cre mice. The efficacy of recombination observed by the PCR analysis indicates the existence of recombination events exclusively in the hippocampus from knockdown mice, but not in controls.

GCL knockdown promoted a decrease in glutathione concentration, in particular a decrease in GSH, and an increase in GSSG, in cultured shGCL ${ }^{\text {floxed }}$-derived MEFs transfected with pCMV-CreER ${ }^{\mathrm{TM}}$. This effect was mild in the absence of tamoxifen, but it was greatly potentiated by the presence of the drug. As above-mentioned, the slight effect on glutathione concentration, observed in the absence of tamoxifen, can be 
ascribed to CreER ${ }^{\mathrm{TM}}$ "leakage". The "leakage” effect of CreER ${ }^{\mathrm{TM}}$ expression in the absence of TM was not observed on total thiols and $\mathrm{H}_{2} \mathrm{O}_{2}$ concentrations, which were only altered if TM was present. This suggests the existence of a threshold of glutathione deficiency for significantly affecting protein sulfhydryls oxidation and efficacy of MEFs to dispose $\mathrm{H}_{2} \mathrm{O}_{2}$. In vivo, glutathione concentrations were unaffected in the tissue samples obtained from different brain areas of the CamKII $\alpha$-Cre/shGCL ${ }^{\text {floxed }}$ mouse. It should be noticed that these samples contain a mixture of all brain cell types; assuming a glutathione concentration of $\sim 2.5 \mathrm{mM}$ in neurons and $\sim 3.5 \mathrm{mM}$ in astrocytes (Zeevalk et al., 2008), and a neuron:astrocyte ratio of 1:3 in rodents (Nedergaard et al., 2003), it would be unfeasible to accurately detect the expected decrease in glutathione concentrations in brain tissue extracts. Therefore, a decrease in glutathione concentration in neurons in vivo in the CamKII $\alpha-C r e / s h G C L^{\text {floxed }}$ mouse cannot be ruled out. This drawback has not affected, though, the oxidised carbonyl detection in whole extracts from the brain areas, as the accumulation of these was sizable; besides, no wonder susceptible impaired neurons can affect the homeostasis of surrounding cells even astrocytes. Oxidized carbonyls appear to increase in the hippocampus of female knockdown mice and, to a much greater extent, in knockdown males. Furthermore, an increase of oxidized carbonyls in the striatum is also seen in knockdown males. Since Cre expression in the CamKII $\alpha$-Cre mice is most active in those brain areas (The Jackon Laboratories), our oxidized carbonyls data strongly suggest that CamKII $\alpha$ $\mathrm{Cre} / \mathrm{sh} G C L^{\text {floxed }}$ mouse is an efficient tool to endogenously trigger oxidative stress in neurons in vivo.

Nissl staining shows that the cytoarchitecture or layer thickness in the hippocampus of the CamKII $\alpha$-Cre/shGCL $L^{\text {floxed }}$ mouse is unaffected. At the time this Doctotral Thesis is being written, we are performing an in depth immunohistochemical analysis, which is highly time-consuming. Moreover, we decided to study males at the first instance in view that, i) they show more oxidized carbonyls than females, and ii) their behavioural impairment is less subtle than in females -as it will be discussed below. Therefore, until a full quantification of all images is complete, we can only supply qualitative data for the immunohistochemical study in males. In general, confocal images allow colocalization and discrimination of selective fluorophore intensities -sequential acquisition-, which assess changes in intensity levels. The anti-GCL confocal images could not accurately determine a clear decrease in GCL signal intensity, a fact that is 
probably due to the particularly low detectable levels of GCL protein in brain (Godoy et al., 2011). However, we cannot disregard problems derived form the antibody used; it should be mentioned that there is a very poor offer of commercially available anti-GCL antibodies for immunohistochemistry. We would like to note that our shGCL floxed mouse has been crossed with a pancreas-specific Cre mouse in the laboratory of Prof. Juan Sastre (University of Valencia, Spain), and the preliminary results show a $\sim 60 \%$ decrease in GCL protein in the pancreas as assessed by western blotting (Juan Sastre, personal communication). These data confirm the usefulness of our shGCL $L^{\text {floxed }}$ approach to knockdown GCL tissue-specifically. Furthermore, glutathionylated proteins in the brain of the CamKII $\alpha$-Cre/shGCL ${ }^{\text {floxed }}$ mouse are decreased, thus inferring a low GSH availability for protein glutathionylation (Franco and Cidlowski, 2009). In addition, an accumulation of nitrated proteins could be detected, evidencing an increase in oxidative stress. The denser spots that co-localized neatly for 3-nitro-tyrosine and GSH would need a detailed study, as they seem to correspond to vesicular localization or aggregated proteins. Interestingly, CamKII $\alpha$ staining was more intense in knockdown males than in controls, as judged by the images shown in Figs. 14 and 16; however, the higher staining intensity was not so evident in Fig. 14. In this context, it should be noticed that the fluorophore used was different in both experiments; Cy5 was used for the former, whereas Alez594 for the latter. In addition, we observed an increased intensity in the phosphorylated form of CamKII $\alpha$ (Fig 15). Further studies need to be carried out in the context of a possible link between this result and the cognitive alterations -as discussed below-; in fact, CamKII $\alpha$ has a critical role in memory and learning (Yamauchi, 2005).

The behavioral tests yielded mixed conclusions depending on the sex, for which we still do not have a convincing explanation. Differences in circulating estrogen levels, which are higher in females, could be responsible for a better protection of females against oxidative stress (Behl et al., 1995); however, this issue still needs to be confirmed. Regarding the motor balance and coordination tests, we show that knockdown males showed locomotor impairment, whereas knockdown females do not. In view that the oxidized carbonyls detection was higher in the striatum of knockdown males, but not in females, strongly suggests a direct link between oxidative stress in the striatum and locomotor problems. This is, to the best of our knowledge, be first direct in vivo evidence showing that oxidative stress specifically in the striatum would be a trigger of 
the motor coordination problems in certain neurological diseases, such as Parkinson's disease. Noticeably, the cognitive ability of control male was better than control females; however, this improvement in the spatial memory was lost in the knockdown males. In this context, there is a previous study linking oxidative stress and memory impairment in a mild whole-body GSH deficiency transgenic mice model (Chen et al., 2012). Unfortunately, sex differences were not taken into account and the oxidative stress was produced in all cells of the body, hence precluding from obtaining a direct cause-effect link (Chen et al., 2012). According to our tests, knockdown females showed significant -albeit mild- signs of fear/anxiety; in this context, it is known that oxidative stress is known to be associated with the pathogenesis of anxiety. Thus, shock-induced experimental behavioral depression in mice causes a mild deficiency in the brain concentration of glutathione (Pal and Dandiya, 1994). Moreover a mild GSH deficiency in all cells of the body of a transgenic mice triggers symptomatic behavior compatible with anxiety (Chen et al., 2012); unfortunately, this whole-body GSH deficiency caused oxidative stress-mediated massive hepatic failure, secondary leading to a metabolic imbalance resulting in generalized pathological status damaging to all tissues, besides the brain. However, in anxiety only hippocampal neurons are affected (Rosen and Schulkin, 1998), hence our data suggests that neuron-specific oxidative stress may be a cause of anxiety.

In conclusion, here we describe a novel strategy for studying oxidative stress in vivo in a tissue specific and time-controlled manner. This model may open new possibilities to study the involvement of elevated ROS in mental illnesses, such as Alzheimer's disease or anxiety, which are intrinsic to a number of psychiatric disorders including depression, panic attacks, phobias, obsessive-compulsive disorder and post-traumatic stress (Gross and Hen, 2004); however, these diseases currently lack of appropriate in vivo models for research on new therapeutic strategies. Furthermore, since we designed the genetic tool with two unique restriction sites flanking the shRNA sequence, new transgenic mice models could be straightforward generated to knockdown any other protein tissue-specifically in vivo. We believe that the transgenic mouse model herein described may be useful for a better understanding of the consequences of oxidative stress in specific cells in vivo, as well as for assessing novel pharmacological approaches. 


\section{Figures and Tables}

Nicht Kunst und Wissenschaft allein, Geduld will bei dem Werke sein

(Not art and science only, but patience will be required for the work) Johann Wolfgang von Goethe (free translation). 


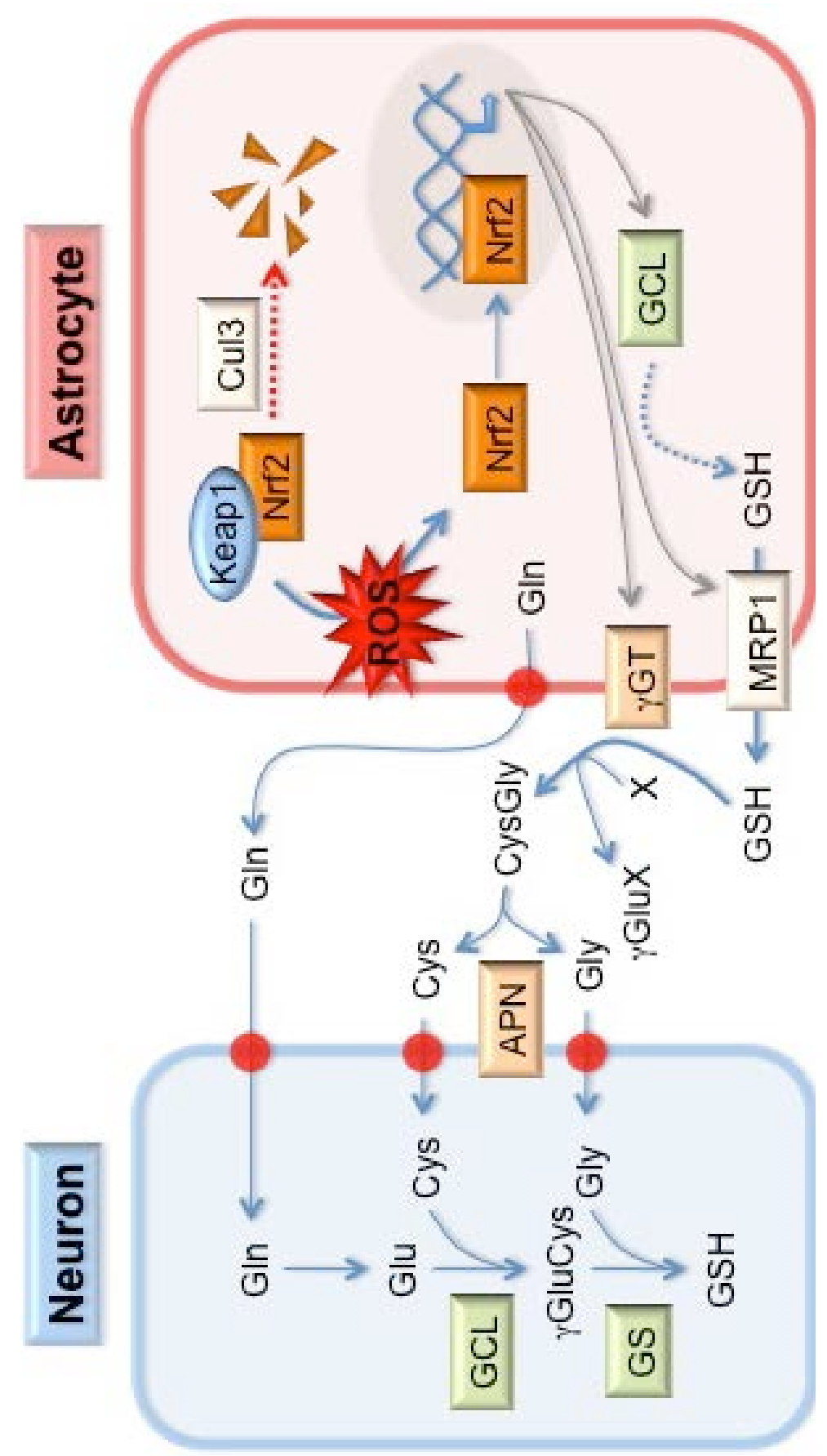

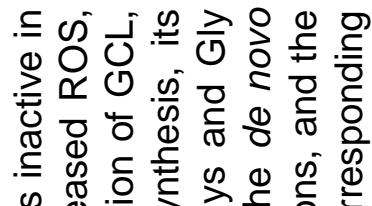

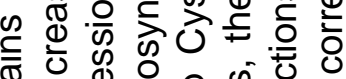

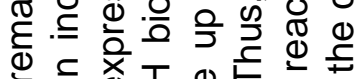
Ф

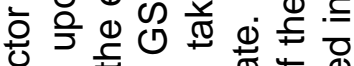

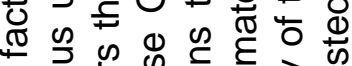
등 क

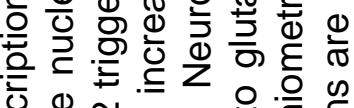

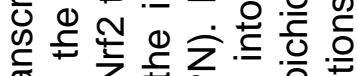
휸은

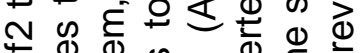
之艺悉

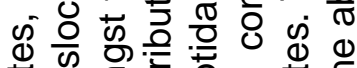

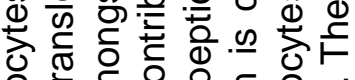

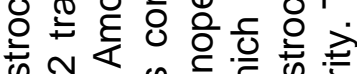

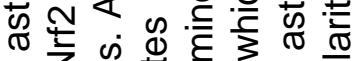
¿

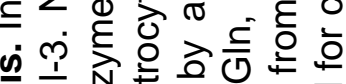
"

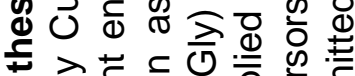

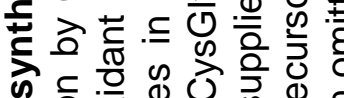

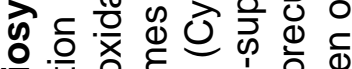

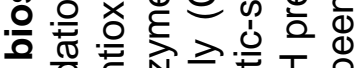

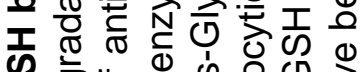

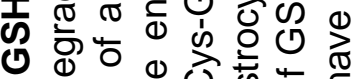

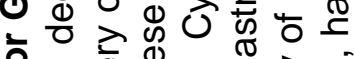

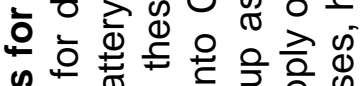

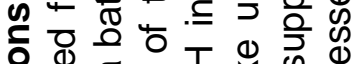

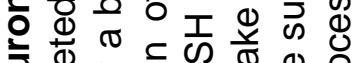

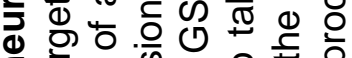
츠 댕유 등 응

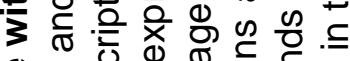

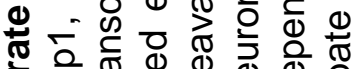

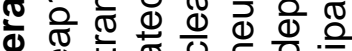

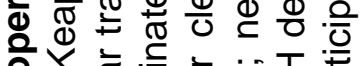

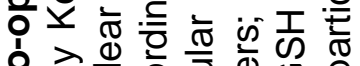

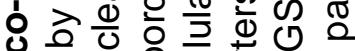
y 웡 ए

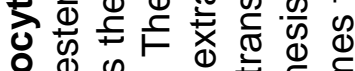
웡

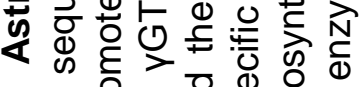

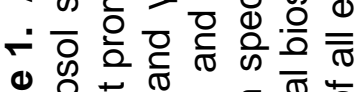

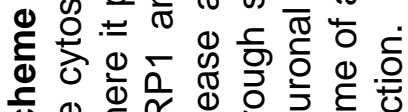

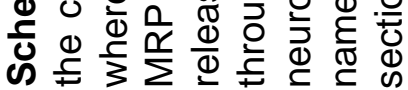


a)

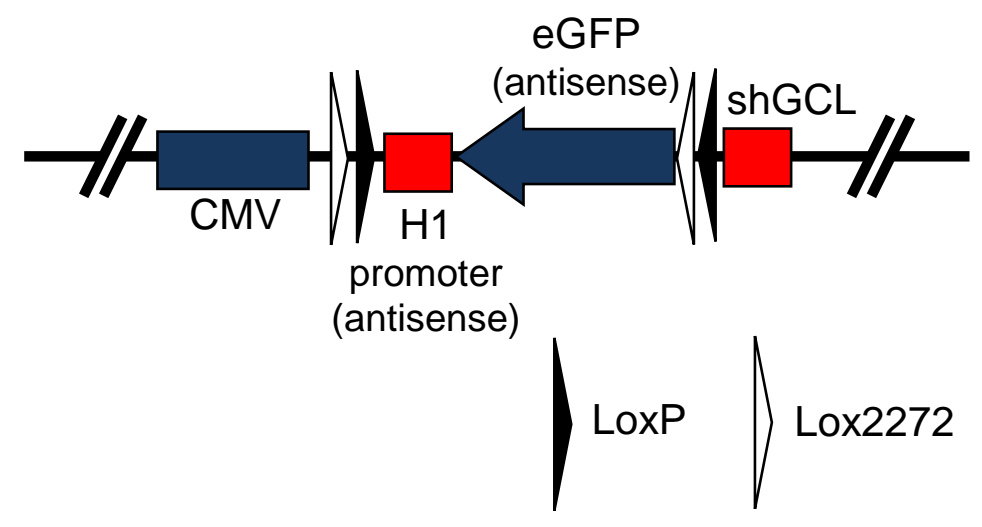

b)

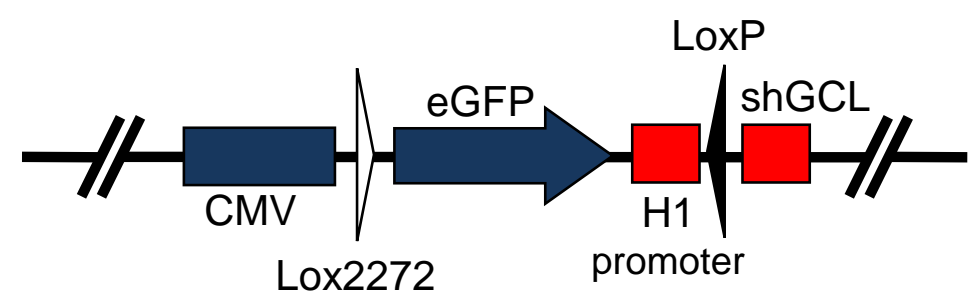

Scheme 2. shGCL floxed construct operation. a) Configuration elements of the shGCL floxed $C D N A$ construct prior to Cre-mediated recombination. CMV promoter and $s h G C L$ sequences are placed in the sense orientation, whereas $\mathrm{H} 1$ promoter and eGFP sequences are placed in the antisense orientation. Lox2272 (white-head arrow) and LoxP (black-head arrow) sequences are placed both in the sense and in the antisense orientations. b) Configuration elements of the $s h G C L^{\text {floxed }}$ construct after Cre-mediated recombination for shGCL expression. All elements, except LoxP, are placed in the sense orientation. This configuration is stable and no longer susceptible to recombination. 


\begin{tabular}{|c|c|c|c|c|}
\hline \multicolumn{1}{|c}{ Element } & Plasmid & Size (bp) & RE 5'/ coord. & RE 3'/ coord \\
\hline CMV & pIRES2-EGFP & 590 & AseI (6) & NheI (591) \\
\hline Neomicine & pcDNA 3.1 (+) & 1167 & XmaI (2075) & SalI (3241) \\
\hline H1 & pSUPER.neo+GFP & 227 & EcoRI (2960) & BglII (3181) \\
\hline eGFP & pEGFP-C1 & 996 & AgeI (600) & MluI (1641) \\
\hline
\end{tabular}

Table 1. Plasmids used to clone and subclone cDNA elements during the construct generation. Plasmids used, and the elements taken from each of them for the construct generation are shown. Elements are specified according to their original coordinates. The restriction enzymes (RE) used for excision or cloning of each element are also shown. 


\begin{tabular}{|c|c|c|}
\hline Oligonucleotide & Name & Sequence \\
\hline \multirow[t]{2}{*}{ Lox2272_sense } & FwL2s & $\begin{array}{l}\text { 5'-CTA GAT AAC TTC GTA TAA AGT ATC } \\
\text { CTA TAC GAA GTT ATC-3', }\end{array}$ \\
\hline & RvL2s & $\begin{array}{l}\text { 5'-CCG GGA TAA CTT CGT ATA GGA TAC } \\
\text { TTT ATA CGA AGT TAT-3' }\end{array}$ \\
\hline \multirow[t]{2}{*}{ Lox2272_antisense } & FwL2a & $\begin{array}{l}\text { 5'-CCG GAT AAC TTC GTA TAG GAT ACT } \\
\text { TTA TAC GAA GTT ATG ATA CCA GAT } \\
\text { ACC AGA G-3' }\end{array}$ \\
\hline & RvL2a & $\begin{array}{l}\text { 5'-CTA GCT CTG GTA TCT GGT ATC ATA } \\
\text { ACT TCG TAT AAA GTA TCCT ATA CGA } \\
\text { AGT TAT-3' }\end{array}$ \\
\hline \multirow[t]{2}{*}{ LoxP_antisense } & FwLPa & $\begin{array}{l}\text { 5'-CTA GAT AAC TTC GTA TAG CAT ACA } \\
\text { TTA TAC GAA GTT ATA GAT CTA AGC } \\
\text { TTG CGG CCG CAT-3' }\end{array}$ \\
\hline & RvLPa & $\begin{array}{l}\text { 5'-TAA TGC GGC CGC AAG CTT AGA TCT } \\
\text { ATA ACT TCG TAT AAT GTA TGC TAT } \\
\text { ACG AAG TTA T-3' }\end{array}$ \\
\hline \multirow[t]{2}{*}{ LoxP_sense } & FwLPs & $\begin{array}{l}\text { 5'-TCG ACC CGG GAT ACC AGT CGA } \\
\text { CAA AAA ATA ACT TCG TAT AAT GTA } \\
\text { TGC TAT ACG AAG TTA T-3' }\end{array}$ \\
\hline & RvLPs & $\begin{array}{l}\text { 5'-GAT CAT AAC TTC GTA TAG CAT ACA } \\
\text { TTA TAC GAA GTT ATT TTT TGT CGA } \\
\text { CTG GTA TCC CGG G-3' }\end{array}$ \\
\hline \multirow[t]{2}{*}{ Adaptor1 } & FwAd1 & $\begin{array}{l}\text { 5'-AAT TGA TAC CAG ATA CCA CGC GTG } \\
\text { C-3' }\end{array}$ \\
\hline & RvAd1 & $\begin{array}{l}\text { 5'-GGC CGC ACG CGT GGT ATC TGG } \\
\text { TAT C-3' }\end{array}$ \\
\hline \multirow[t]{2}{*}{ ShGCL } & FwD & $\begin{array}{l}\text { 5'-GAT CCC CGA AGG AGG CTA CTT } \\
\text { CTA TAT TCA AGA GAT ATA GAA GTA } \\
\text { GCC TCC TTC TTT TTG GAA A-3' }\end{array}$ \\
\hline & RvD & $\begin{array}{l}\text { 5'-AGC TTT TCC AAA AAG AAG GAG GCT } \\
\text { ACT TCT ATA TCT CTT GAA TAT AGA } \\
\text { AGT AGC CTC CTT CGG G-3' }\end{array}$ \\
\hline
\end{tabular}

Table 2. Oligonucleotides sequences of relevant cDNA fragments used during the construct generation. The Lox-type sequences were designed to be in the correct sense. Spacers and other signal sequences such as restriction sites and transcription end signals are not shown. 


\begin{tabular}{|c|c|c|}
\hline Restriction Enzyme & Sequence & Company \\
\hline AflII & C/TTAAG & New England Biolabs \\
\hline AgeI & A/CCGGT & Promega \\
\hline AseI & AT/TAAT & New England Biolabs \\
\hline BamHI & G/GATCC & Promega \\
\hline BclI & T/GATCA & Promega \\
\hline BglII & A/GATCT & Promega \\
\hline EcoRI & G/AATTC & Promega \\
\hline HindIII & A/AGCTT & Promega \\
\hline MluI & A/CGCGT & Promega \\
\hline NheI & G/CTAGC & Promega \\
\hline NotI & GC/GGCCGC & Promega \\
\hline SalI & G/TCGAC & Promega \\
\hline XhoI & C/TCGAG & Promega \\
\hline XmaI & C/CCGGG & Promega \\
\hline & &
\end{tabular}

Table 3. Restriction enzymes used in this work. 


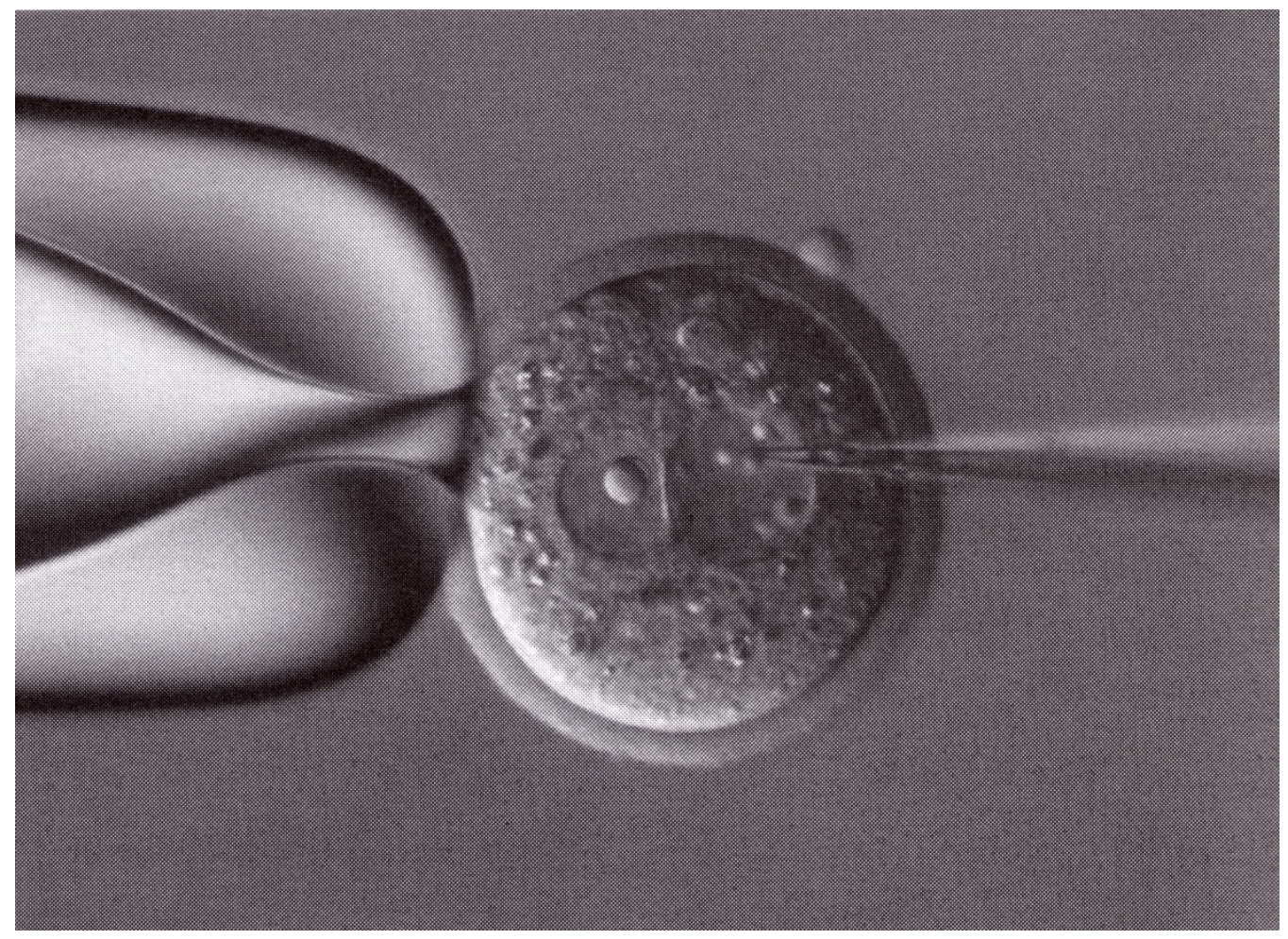

Scheme 3. DNA microinjection. Micropipette injecting DNA in a one-cell state oocyte held by a pipette. Taken from Nagy (2003) (Cold Spring Harbor Laboratory Press). 


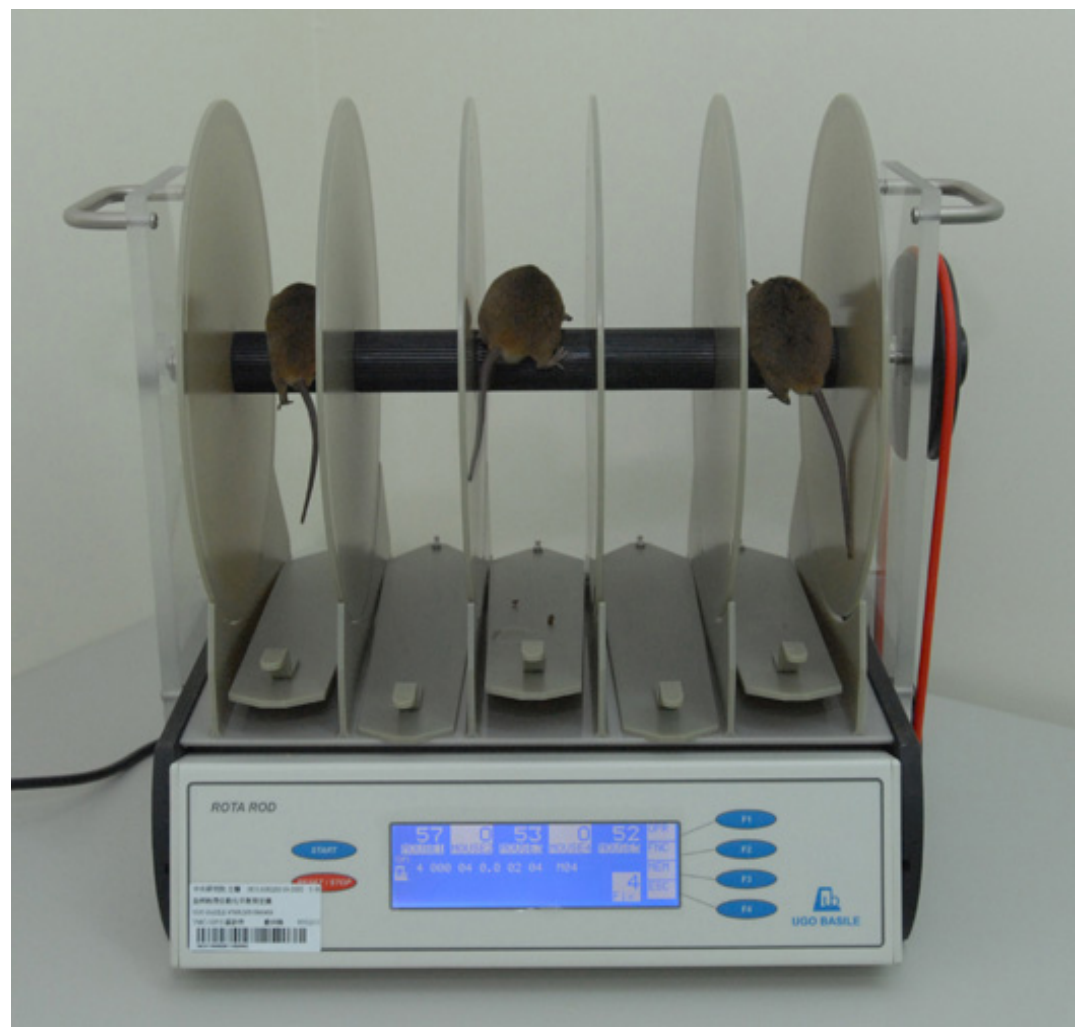

Scheme 4. Rotarod test. Mice are placed in an accelerating rod, and the latency to fall (in seconds) is measured as an index of motor balance and coordination. (Image from Stoelting). 
a)

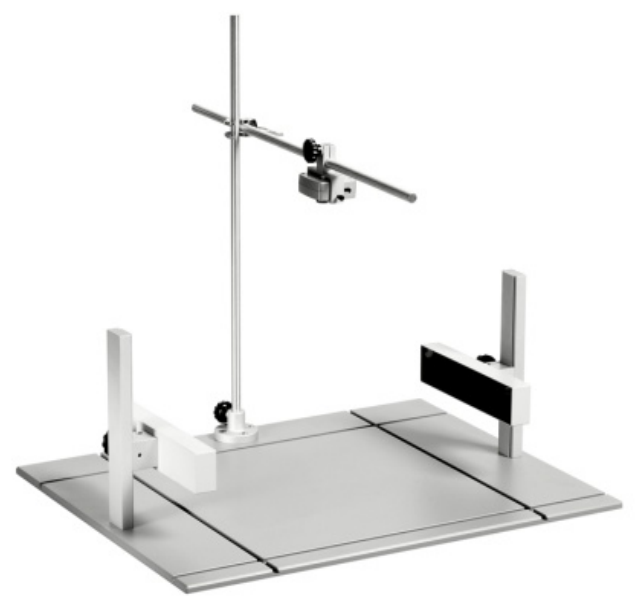

b)

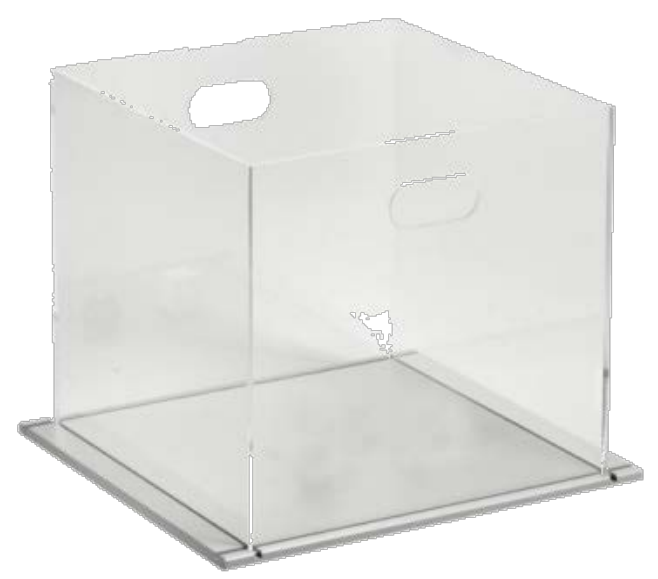

c)

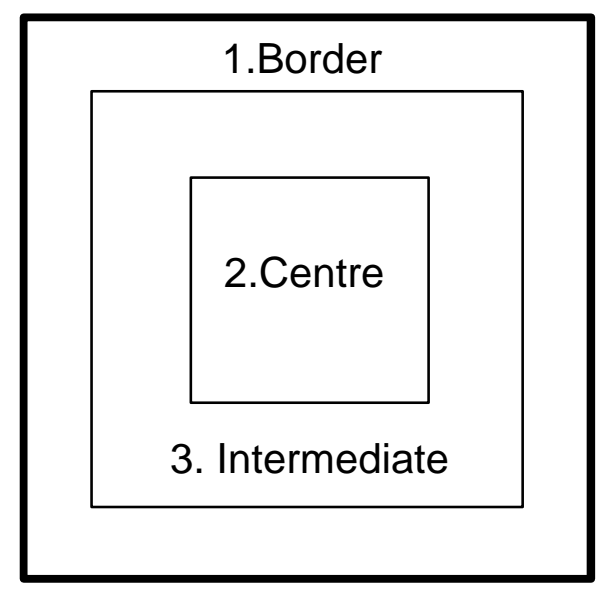

Scheme 5. Open Field test. Description of the equipment used to assess fear/anxiety in mice. a) Any-box platform core. A light grey base containing a camera (height-adjustable), an infrared photo-beam array to track animal movements, and a rearing detection. Animal movements were tracked with the ANY-maze software using an AMi interface (not shown). b) Open Field insert. The $40 \mathrm{~cm} \times 40 \mathrm{~cm} \times 35 \mathrm{~cm}(\mathrm{w}, \mathrm{d}, \mathrm{h}$ ) infrared-transparent Perspex black insert (a visible one is shown, for illustration). c) The Open Field arena. This was divided in the following zones: 1 . Border ( $8 \mathrm{~cm}$ wide), 2. Centre (16\% of total arena), and 3. The intermediate (remaining zone left). 
a)

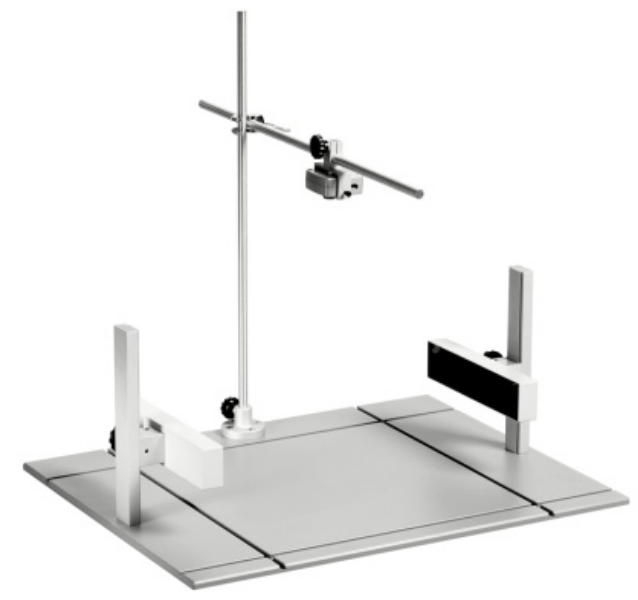

b)

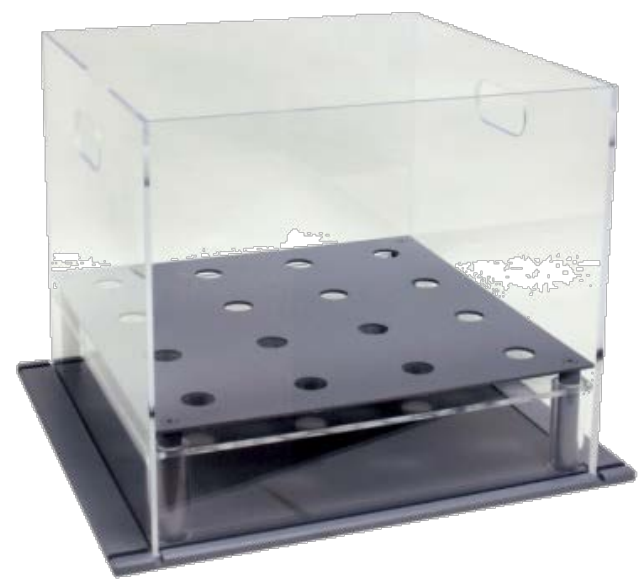

Schme 6. Hole-board test. Description of the Stoelting automated Hole-board equipment used to assess fear/anxiety. a) Any-box platform core. A light grey base containing a camera (height-adjustable), an infrared photo-beam array to track animal movements, and a rearing detection. Animal movements were tracked with the ANY-maze software using an AMi interface (not shown). b) Holeboard insert and elevated base. The $40 \mathrm{~cm} \times 40 \mathrm{~cm} \times 35 \mathrm{~cm}(\mathrm{w}, \mathrm{d}, \mathrm{h})$ infraredtransparent Perspex black insert (a visible one is shown, for illustration), fitted snuggly to a raised $40 \mathrm{~cm} \times 40 \mathrm{~cm}$ (w, d) base with 16 holes ( $3 \mathrm{~cm}$ diameter), arranged in a $4 \times 4$ grid raised $10 \mathrm{~cm}$ above the floor. 
a)

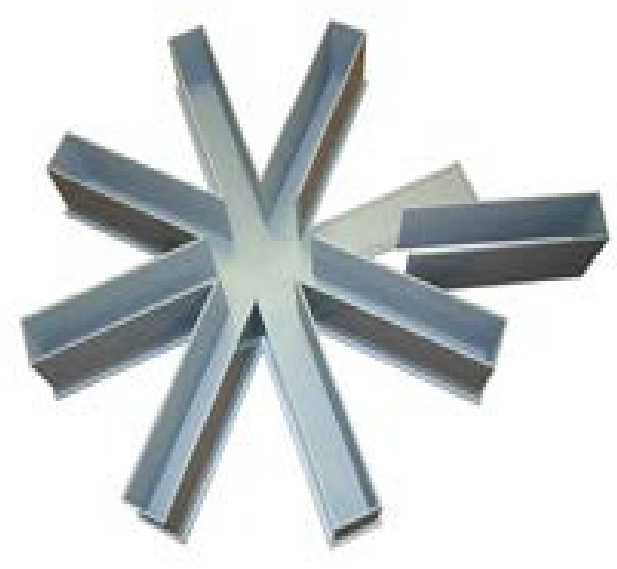

b)

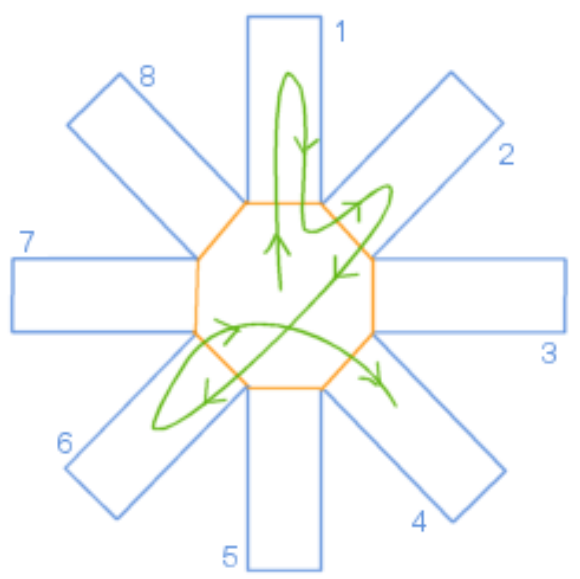

Scheme 7. Radial Arm Maze. Description the automated Stoelting equipment used to assess spatial memory in mice. a) Eight equidistantly-spaced arms radiating from a small central platform. At the end of each arm, a geometric figure was displayed (not shown). The dimensions of each arm are $5 \mathrm{~cm} \times 35 \mathrm{~cm} \times 9 \mathrm{~cm}$ $(w, I, h)$. Arms are removable and fit in the slotted, light grey base shown in schemes 5 and 6. b) Schematic representation of a typical track, which is registered by a software that counts the number of "non-return" sequences, i.e. tracks in which the animal visits all arms only once. 
a)

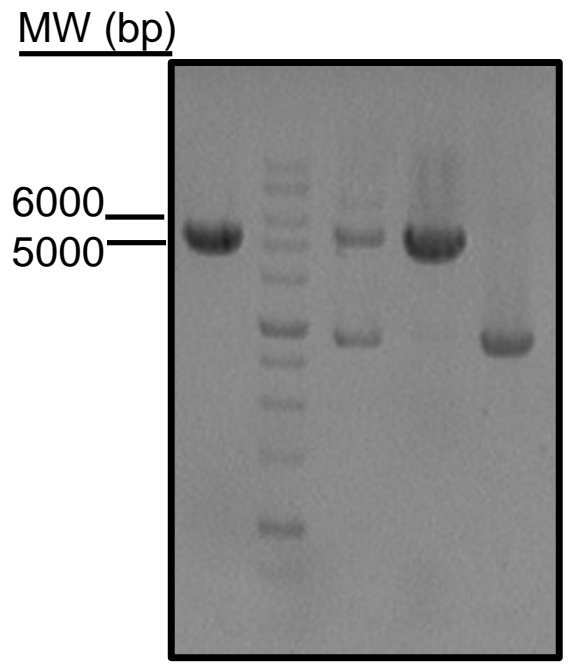

Lane: $1 \quad 2 \quad 3 \quad 4 \quad 5$

c) $\mathrm{MW}(\mathrm{bp})$

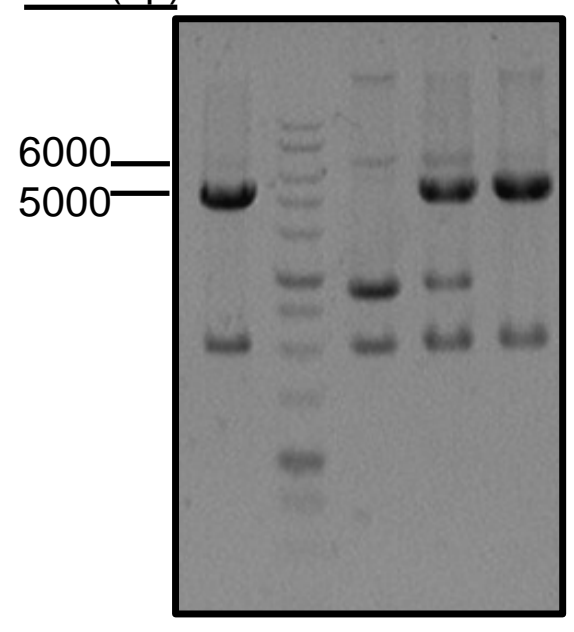

Lane : $1 \quad 2 \quad 3 \quad 4 \quad 5$ b) $\mathrm{MW}(\mathrm{bp})$

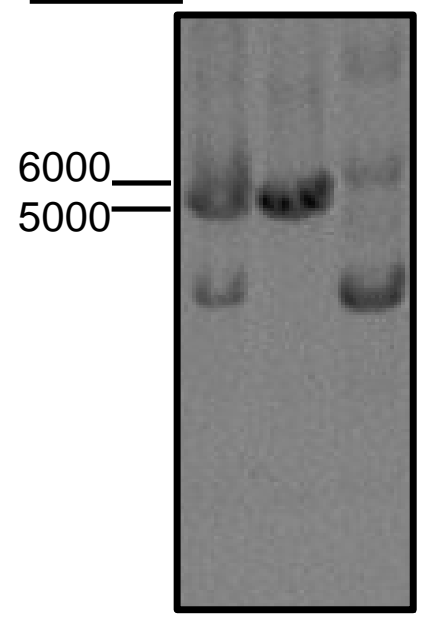

Lane : 123

d) $\mathrm{MW}(\mathrm{bp})$

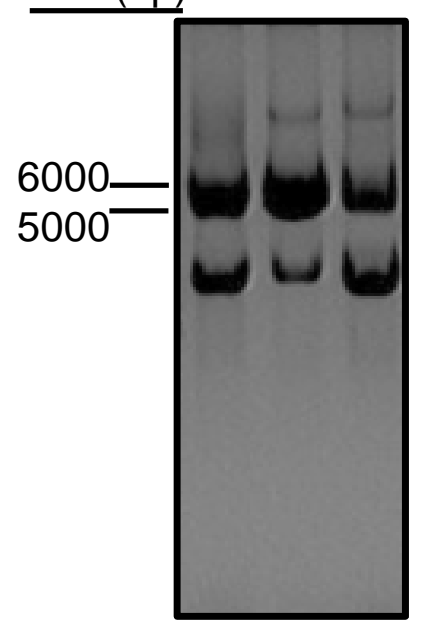

Lane : 123

Figure 1. pPI and pPII plasmids are correctly assembled. Gels are shown in inverted color to improve visualization. a) pIRES2-eGFP digestion. Lane 1: double digestion with Nhel and Xmal, yielding a $5.3 \mathrm{~kb}$ linearized plasmid; lane 2: $1 \mathrm{~kb}$ Biotools marker; lane 3: positive control with Nhel; lane 4: positive control with Xmal; lane 5: negative control (not digested). b) pPI ligation confirmation. Lane 1: negative for Nhel; lane 2: correct size for Xmal digestion; lane 3: negative undigested control. c) pSuper.neo-gfp digestion. Lane 1: double digestion with Bglll and Xhol, yielding a $5.4 \mathrm{~kb}$ linearized plasmid; lane 2: $1 \mathrm{~kb}$ Biotools marker; lane 3: positive control with Bglll; lane 4: positive control with Xhol; lane 5: negative undigested control. d) pPII ligation confirmation. Lane 1: negative for Bglll; lane 2: negative for Xhol; lane 3: negative undigested control. 
a)

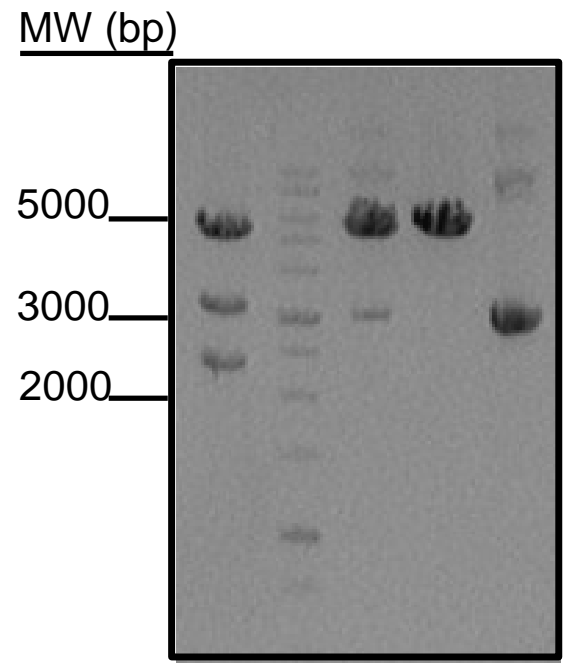

Lane: $1 \quad 2 \quad 3 \quad 4 \quad 5$

c) $\mathrm{MW}(\mathrm{bp})$

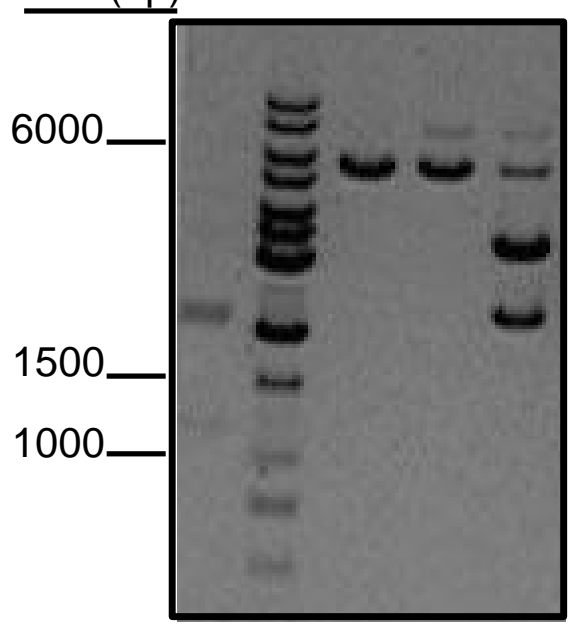

Lane: $1 \quad 2 \quad 3 \quad 4 \quad 5$ b) $\mathrm{MW}(\mathrm{bp})$

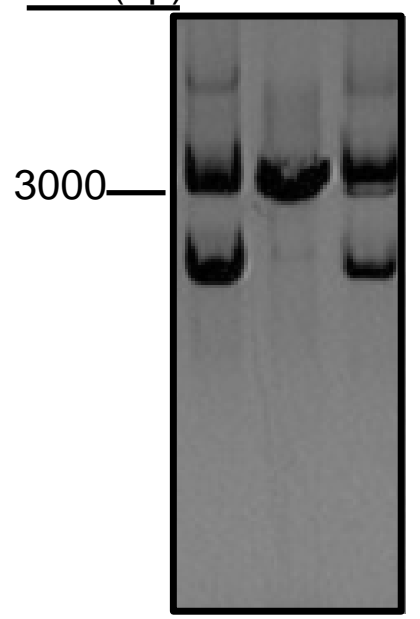

Lane: 1223

d) $\mathrm{MW}(\mathrm{bp})$

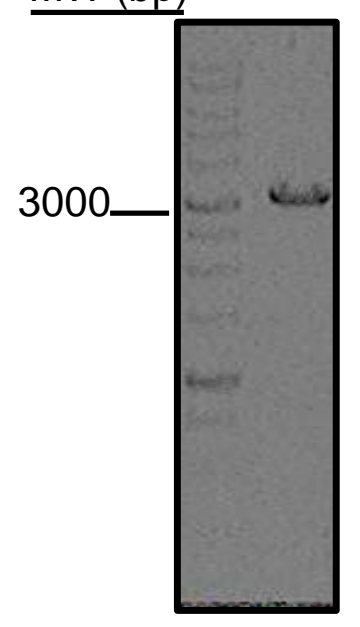

Lane : 12

Figure 2. pPIII and pPIV plasmids are correctly assembled. Gels are shown in inverted color to improve visualization. a) pPII digestion. Lane 1: double digestion with EcoRI and Notl, yielding a $3 \mathrm{~kb}$ linearized plasmid; lane 2: $1 \mathrm{~kb}$ Biotools marker; lane 3: positive control with EcoRI; lane 4: positive control with Notl; lane 5: negative undigested control. b) pPIII ligation confirmation. Lane 1: negative for EcoRl; lane 2: Correct size for Xhol; lane 3: negative undigested control. c) pCDNA3.1(+) digestion. Lane 1: double digestion with Sall and Xmal, yielding a $1.2 \mathrm{~kb}$ neomycin fragment; lane $2: 1 \mathrm{~kb}$ Biotools marker; lane 3: positive control with Sall; lane 4: positive control with Xmal; lane 5: negative undigested control. d) pPIII digestion. Lane 1: $1 \mathrm{~kb}$ Biotools marker; lane 2: double digestion with Sall and Xmal, yielding a $3 \mathrm{~kb}$ linearized plasmid. 
a)

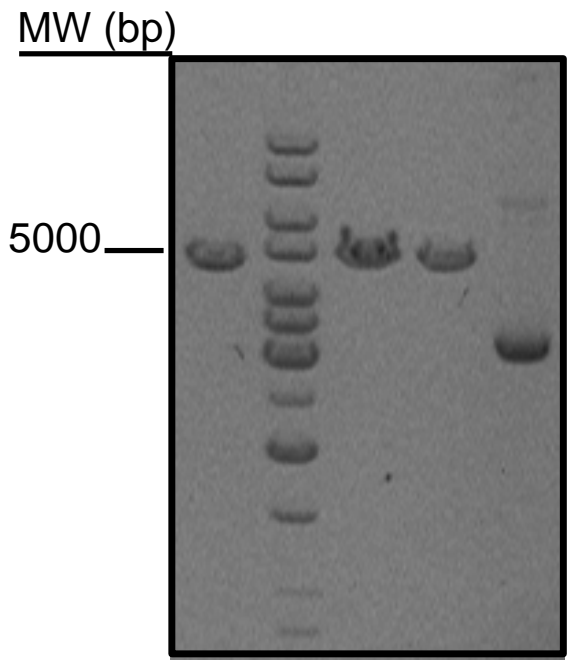

Lane : $1 \quad 2 \quad 3 \quad 4 \quad 5$

c) $\mathrm{MW}(\mathrm{bp})$

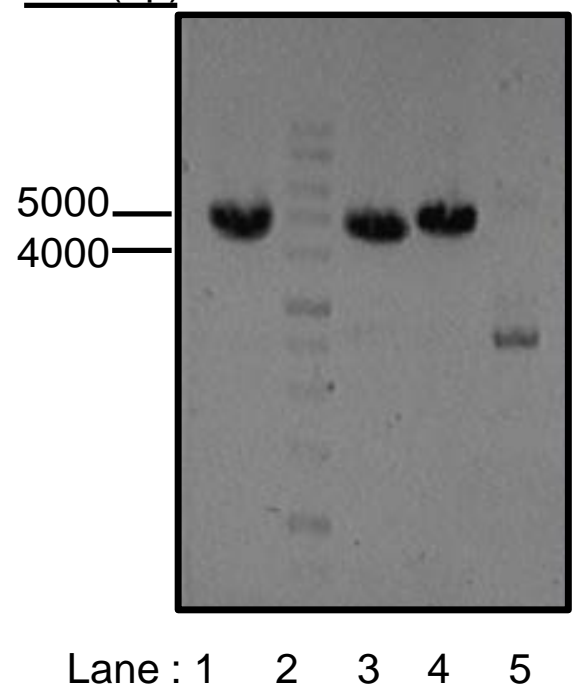

b) $\mathrm{MW}(\mathrm{bp})$

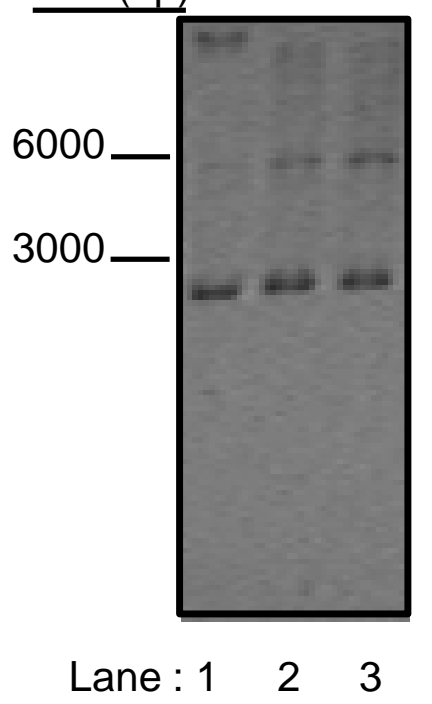

d) $\mathrm{MW}(\mathrm{bp})$

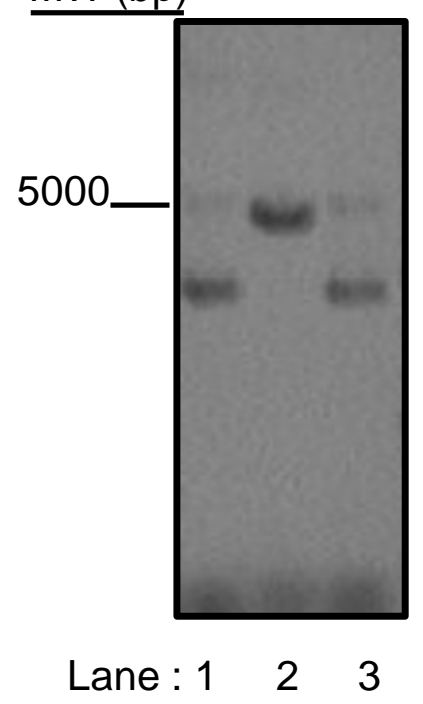

Figure 3. pPV and pPVI plasmids are correctly assembled. Gels are shown in inverted color to improve visualization. a) peGFP-C1 digestion. Lane 1: double digestion with $\mathrm{Bg} / \mathrm{II}$ and $\mathrm{BamHI}$, yielding a $4.7 \mathrm{~kb}$ linearized plasmid; lane 2: $1 \mathrm{~kb}$ Biotools marker; lane 3: positive control with Bglll; lane 4: positive control with BamHI; lane 5: negative undigested control. b) pPV ligation confirmation. Lane 1: negative for $\mathrm{Bglll}$; lane 2: negative for $\mathrm{BamHI}$; lane 3: negative undigested control. c) pPV digestion. Lane 1: double digestion with Agel and Nhel, yielding a $4.6 \mathrm{~kb}$ linearized plasmid; lane 2: $1 \mathrm{~kb}$ Biotools marker; lane 3: positive control with Agel; lane 4: positive control with Nhel; lane 5: negative undigested control. d) pPVI ligation confirmation. Lane 1: negative for Agel; lane 2: correct size for Nhel digestion; lane 3: negative undigested control. 
a)

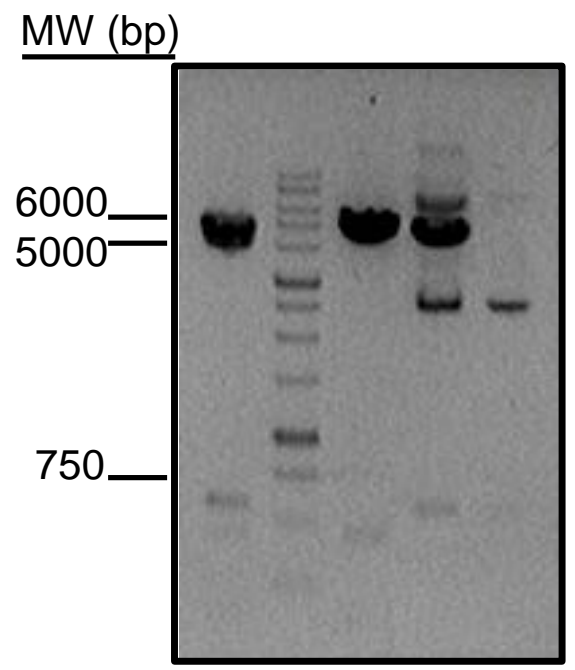

Lane: $1 \quad 2 \quad 3 \quad 4 \quad 5$

c) $\mathrm{MW}(\mathrm{bp})$

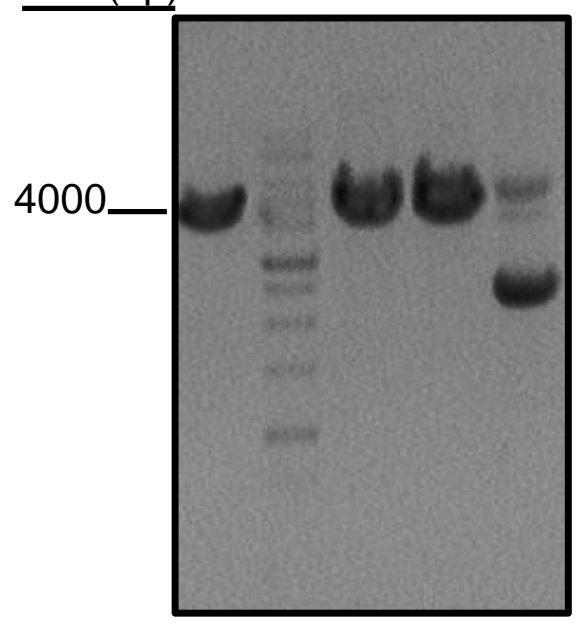

Lane: $1 \quad 2 \quad 3 \quad 4 \quad 5$ b) $\mathrm{MW}(\mathrm{bp})$

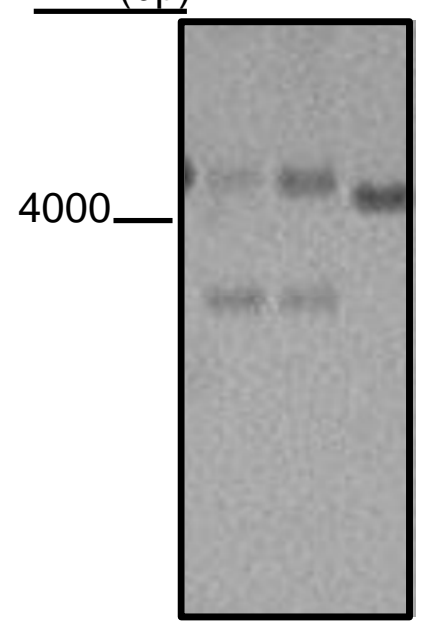

Lane : $1 \quad 2 \quad 3$

d) $\mathrm{MW}(\mathrm{bp})$

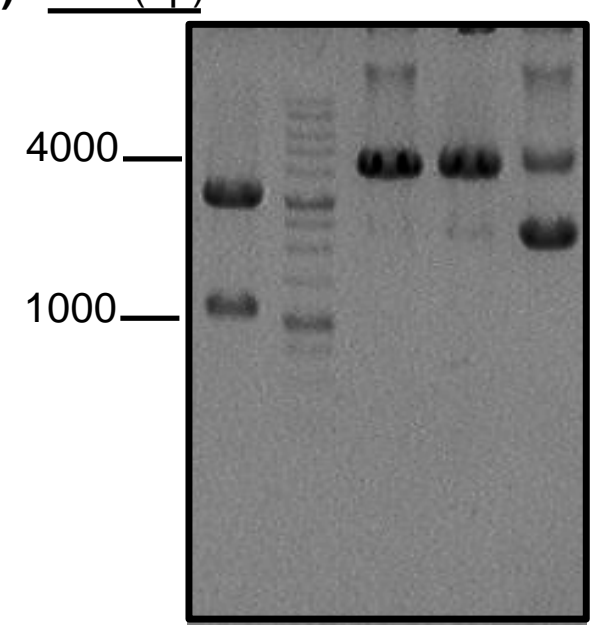

Lane: $1 \quad 2 \quad 3 \quad 4 \quad 5$

Figure 4. pPVII and pPVIII plasmids are correctly assembled. Gels are shown in inverted color to improve visualization. a) pPVI digestion. Lane 1: double digestion with Asel and Nhel, yielding a $3 \mathrm{~kb}$ linearized plasmid; lane 2: $1 \mathrm{~kb}$ Biotools marker; lane 3: positive control with Asel; lane 4: positive control with Nhel; lane 5: negative undigested control. b) pPVII ligation confirmation. Lane 1: negative undigested control; lane 2: negative for Nhel; lane 3: correct size by Asel digestion. c) pPIV digestion. Lane 1: double digestion with Notl and Mlul, yielding a $4.3 \mathrm{~kb}$ linearized plasmid; lane 2: $1 \mathrm{~kb}$ Biotools marker; lane 3: positive control with Notl; lane 4: positive control with Mlul; lane 5: negative undigested control. d) pPVII digestion. Lane 1: double digestion with Notl and Mlul, yielding a $1.2 \mathrm{~kb}$ fragment; lane 2: $1 \mathrm{~kb}$ Biotools marker; lane 3: positive control with Notl; lane 4: positive control with Mlul; lane 5: negative undigested control. 
a) $\mathrm{MW}(\mathrm{bp})$

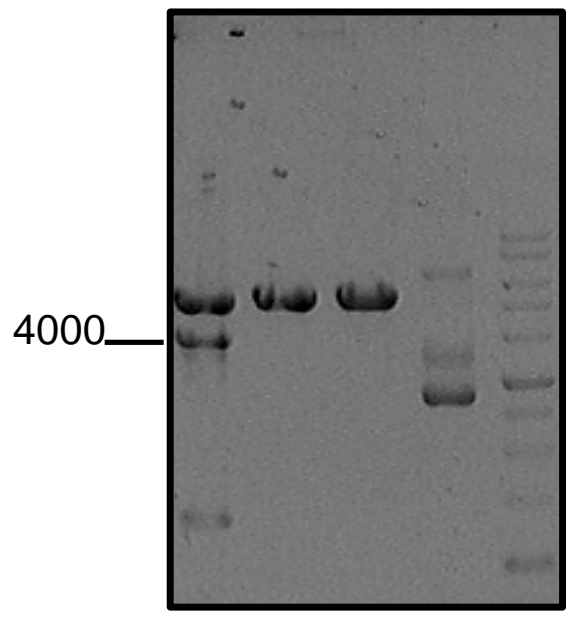

Lane: $1 \quad 2 \quad 3 \quad 4 \quad 5$

c) $\mathrm{MW}(\mathrm{bp})$

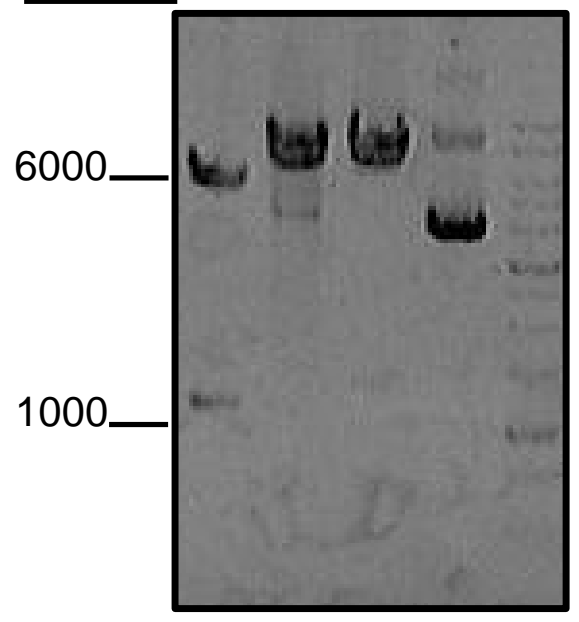

Lane: $1 \quad 2 \quad 3 \quad 4 \quad 5$ b) $\mathrm{MW}(\mathrm{bp})$

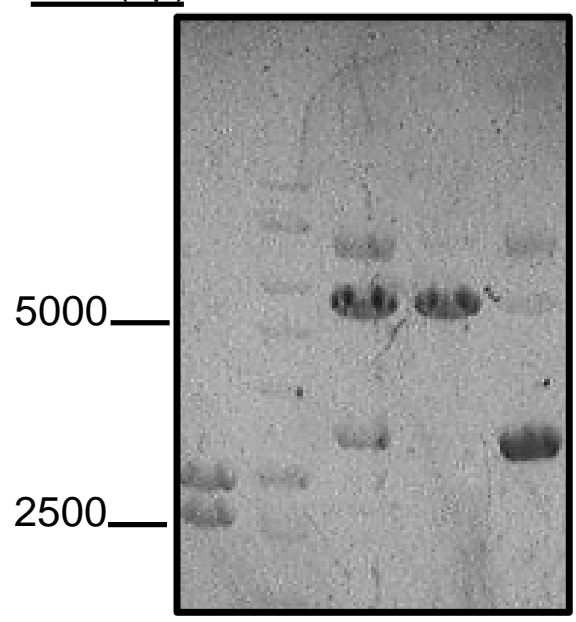

Lane: $1 \quad 2 \quad 3 \quad 4 \quad 5$

d) $\mathrm{MW}(\mathrm{bp})$

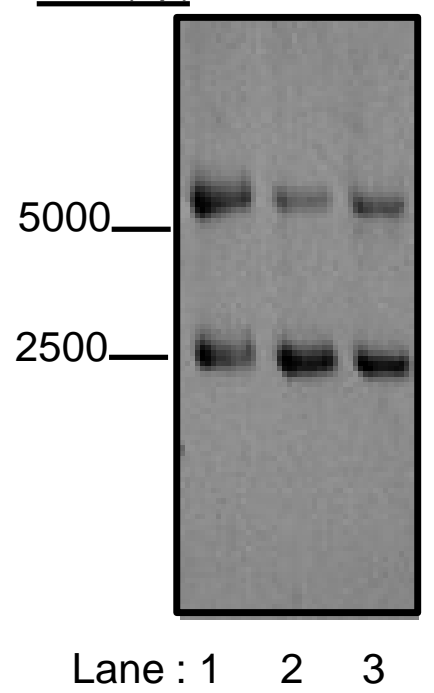

Figure 5. pPIX and pPX plasmids are correctly assembled. Gels are shown in inverted color to improve visualization. a) pPI digestion. Lane 1: double digestion with Notl and Xmal, yielding a $4 \mathrm{~kb}$ linearized vector backbone; lane 2: positive control with Notl; lane 3: positive control with Xmal; lane 4: negative undigested control; lane 5: $1 \mathrm{~kb}$ Biotools marker. b) pPVIII digestion. Lane 1: double digestion with Notl and Xmal, yielding a $2.5 \mathrm{~kb}$ fragment; lane 2: $1 \mathrm{~kb}$ Biotools marker; lane 3: positive control with Notl; lane 4: positive control with Xmal; lane 5: negative undigested control. d) pPIX digestion. Lane 1: double digestion with Sall and Xmal, yielding a $5.4 \mathrm{~kb}$ vector and excised fragment corresponding to neomycin; lane 2: $1 \mathrm{~kb}$ Biotools marker; lane 3: positive control with Sall; lane 4: positive control with Xmal; lane 5: negative undigested control. e) pPX ligation confirmation. Lane 1: negative for Sall; lane 2: negative for Xmal; lane 3: negative undigested control. 
a)

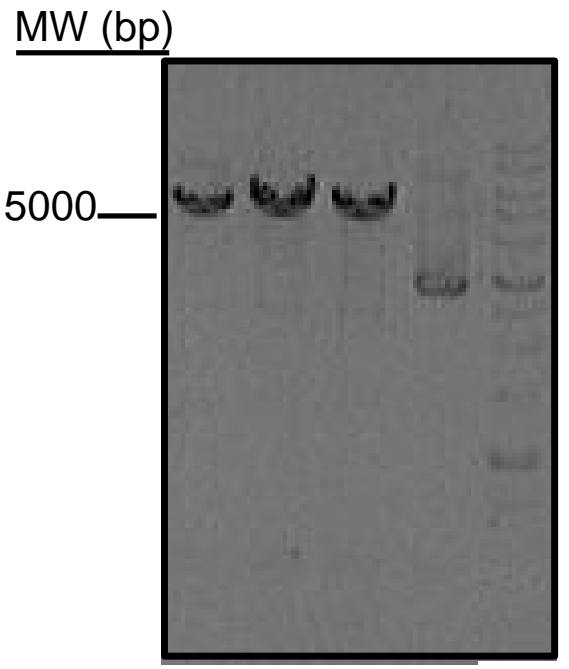

Lane: $1 \quad 2 \quad 3 \quad 4 \quad 5$ b) $\mathrm{MW}(\mathrm{bp})$

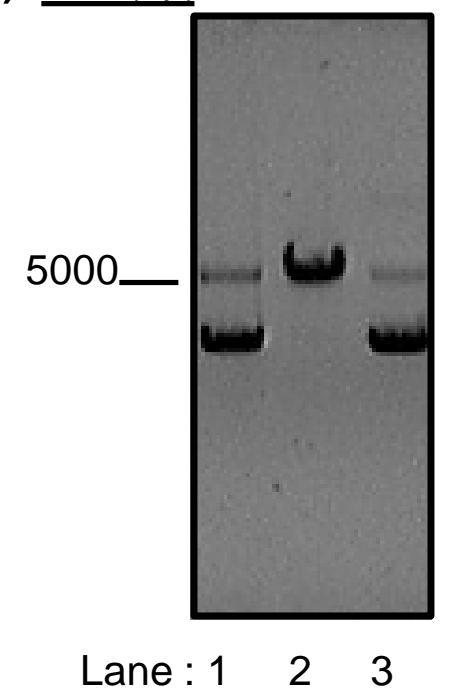

c)

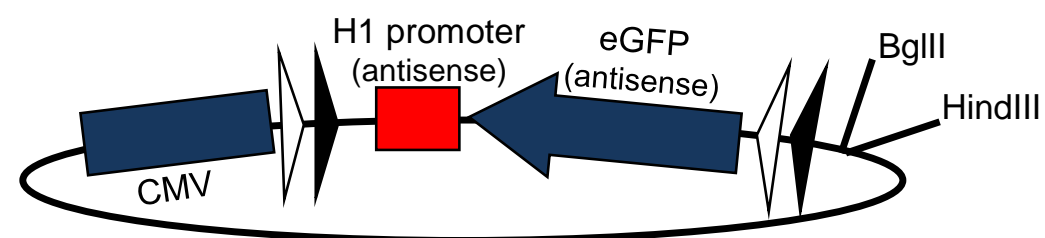

d)

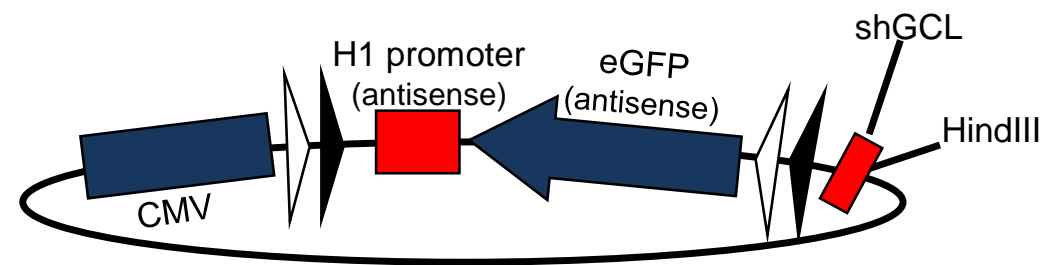

Figure 6. pPXI plasmid is correctly assembled. Gels are shown in inverted color to improve visualization. a) pPX digestion. Lane 1: double digestion with Bglll and Hindlll, yielding a $5.4 \mathrm{~kb}$ vector; lane 2: $1 \mathrm{~kb}$ Biotools marker; lane 3: positive control with Bglll; lane 4: positive control with Hindlll; lane 5: negative undigested control. b) pPXI ligation confirmation. Lane 1: negative for Bglll; lane 2: correct size for Hindlll digestion; lane 3: negative undigested control. c) Schematic representation of $\mathrm{pPX}$ plasmid. CMV promoter is placed in the sense orientation, whereas $\mathrm{H} 1$ promoter and eGFP are placed in the antisense orientation; Lox 2272 (white-head arrow) and loxP (black-head arrow) are placed both in the sense and in the antisense orientations. Please note the unique Blgll and HindIII restriction sites. d) Schematic representation of $\mathrm{PPXI}$ plasmid. This plasmid contains the same elements as in c, except that an shRNA against GCL, catalytic subunit (shGCL) is inserted; the Bglll site (that was present in $p X$ plasmid) was deleted upon ligation. 
a)

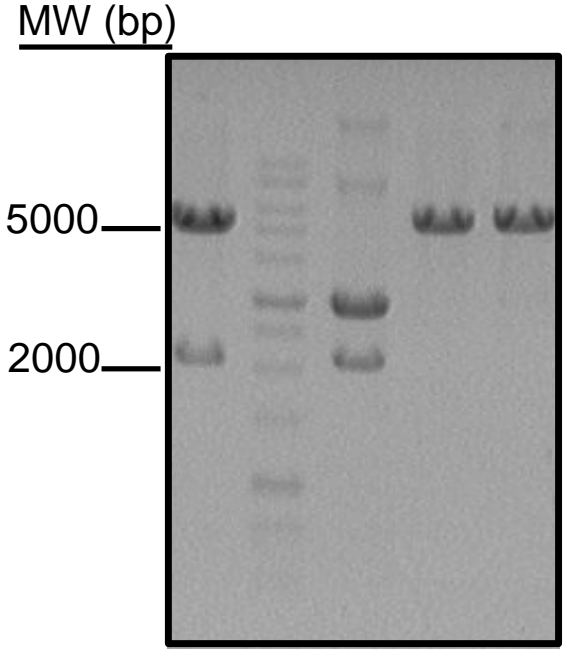

Lane: $1 \quad 2 \quad 3 \quad 4 \quad 5$ b) $\mathrm{MW}(\mathrm{bp})$

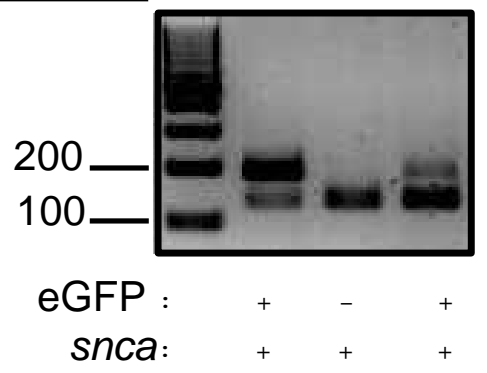

c)

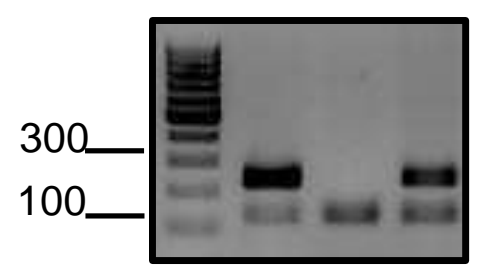

Cre:

snca:

d)

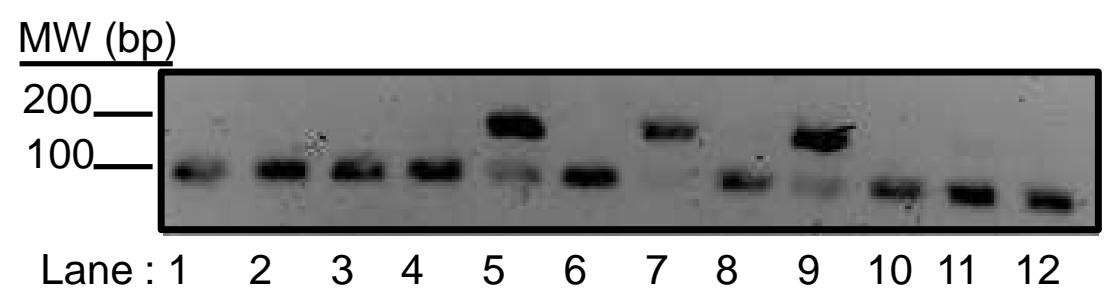

Figure 7. $p X I$ plasmid-derived shGCL floxed construct microinjection successfully yields shGCL floxed mice founders. Gels are shown in inverted color to improve visualization. a) shGCL floxed construct is correctly excised from PPXI plasmid for microinjection. Lane 1: negative undigested control; Lane 2: $1 \mathrm{~kb}$ Biotools marker; Lane 3: double digestion with Aflll and Asel showing the $\sim 2200$ bp fragment used for microinjections; Lane 4: positive control for Aflli; Lane 5: positive control for Asel. b) The shGCL floxed transgene is correctly genotyped. PCR analysis of $S h G C L^{\text {floxed }}$ transgene using primers to amplify eGFP (yielding a 200 bp band) and snca (yielding a $\sim 150$ bp band; used as an internal control). c) The CamKIl $\alpha$-Cre transgene is correctly genotyped. PCR analysis of CamKIll-Cre transgene using primers to amplify a Cre fragment (yielding a 270 bp band) and snca (yielding a $\sim 150$ bp band; used as an internal control). d) Successful generation of shGCL floxed mice founders. PCR analysis of $s h G C L^{\text {floxed }}$ transgene using primers to amplify eGFP (yielding a $\sim 200$ bp band) and snca (yielding a 150 bp band; used as an internal control). Only lanes 5, 7 and 9 correspond to positive founders corresponding to $\operatorname{shGCL}^{\text {floxed }}-1$, to shGCL floxed-2, and to shGCL ${ }^{\text {floxed }}$-3 founder lines. 


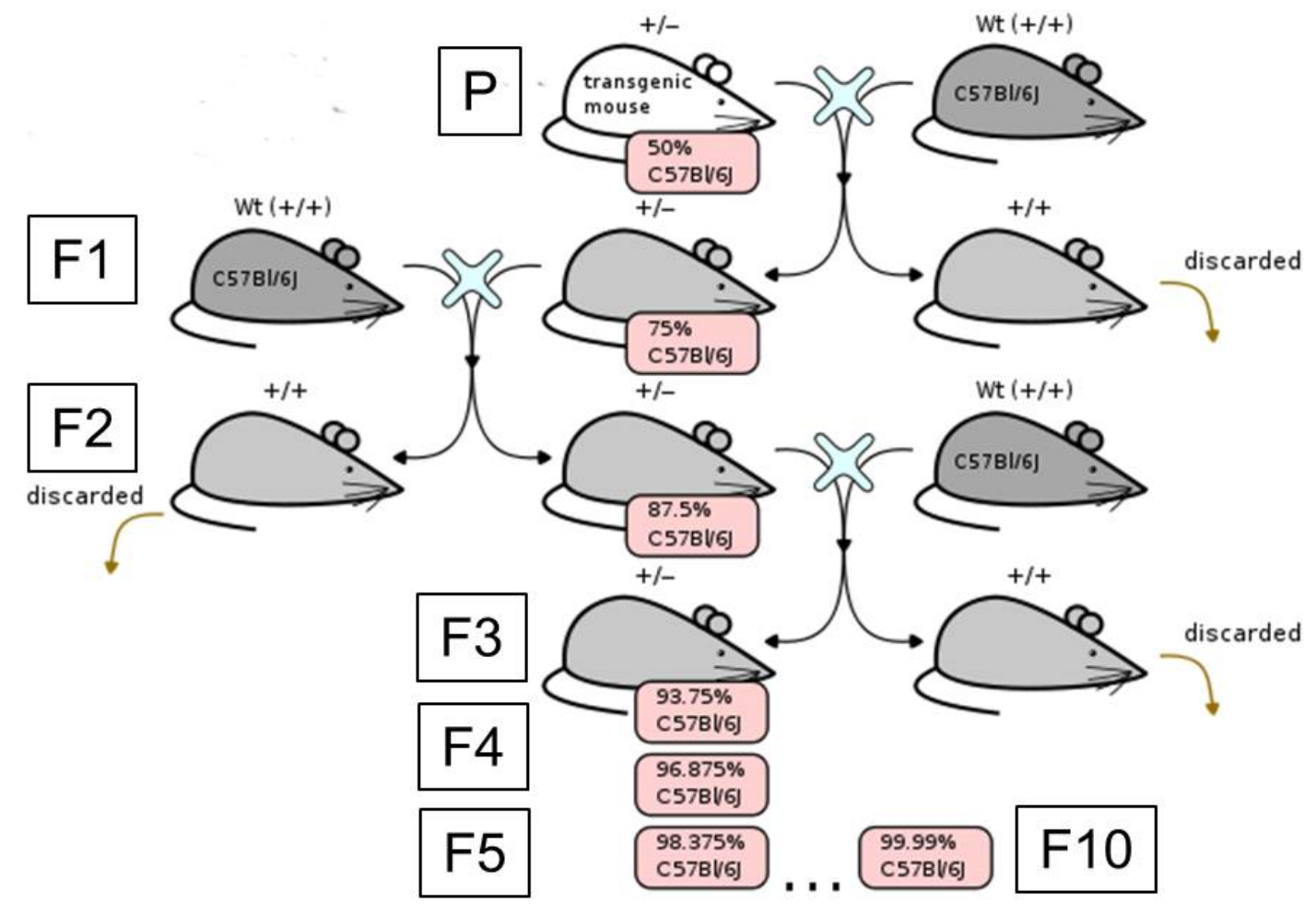

Scheme 8. shGCL floxed founders backcrossing. Parental (P) shGCL floxed founders hemizygous for the transgene [shGCL(+/-)], were backcrossed with wild type C57BI/6J mice. Mice not carrying the construct in the progeny were discarded. Positive carriers were subsequently backcrossed to increase the genomic homogeneity of the $\mathrm{C} 57 \mathrm{BI} / 6 \mathrm{~J}$ background. Please note the percentages of homogeneity for each generation. The generation number is denoted as F1, F2, ... Animals were considered congenic at the tenth generation (F10). 
a)

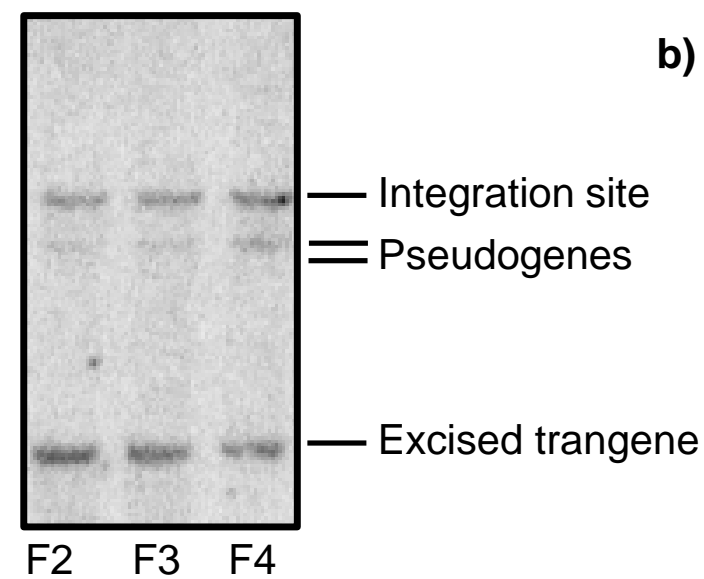

b)

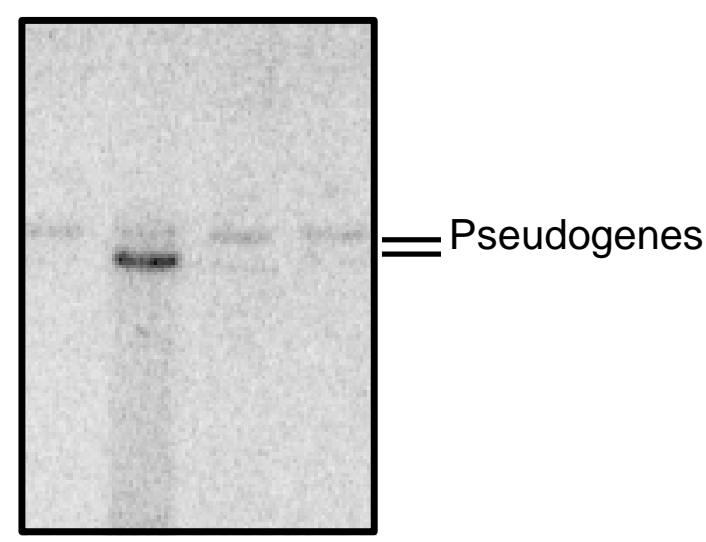

F1 $\begin{array}{llll}\text { F2 } & \text { F3 } & \text { F4 }\end{array}$

c)

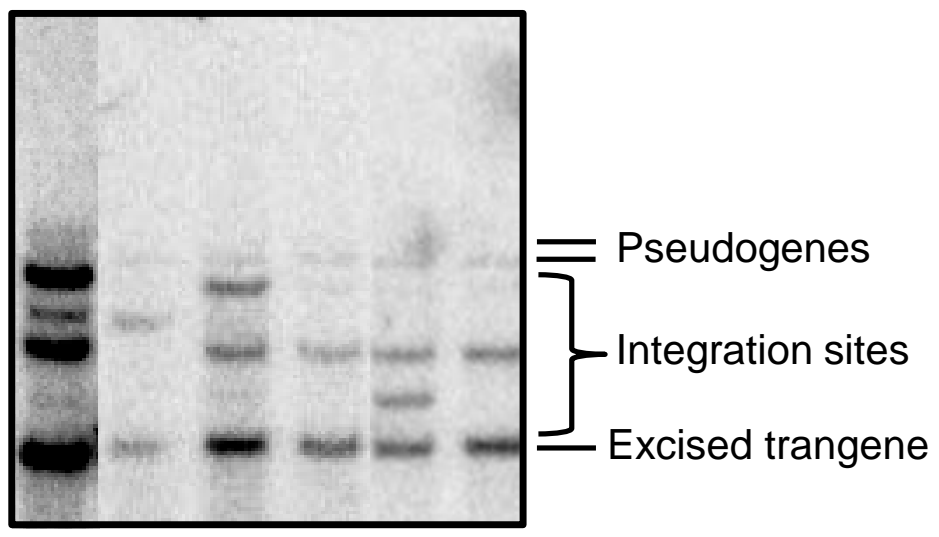

$\begin{array}{llllll}\text { F1 } & \text { F3 } & \text { F3 } & \text { F3 } & \text { F4 } & \text { F4 }\end{array}$

Figure 8. Southern analysis of $s h G C L^{\text {floxed }}$ sublines 1,2 and 3. Genomic DNA was digested with Hindlll and eGFP was used asprobe. For each lane it is indicated the generation from which the mouse proceeded. Two little intense band were seen in all cases that probably correspond to pseudogenes. a) shGCL floxed_ 1 mice southern. Correct band size for transgene can be visualized corresponding to excised tandem copies. A unique integration site can be observed from generation 2 onwards. b) shGCL ${ }^{\text {floxed }}-2$ mice southern. A band for the transgene can not be seen. Unique copy integrations are not usual. Besides, it does not remain clear if an integration site really exists. Initial identification was performed with PCR which could give false positives. Further analysis is required c) $s h G C L^{\text {floxed }}-3$ mice southern. Up to three integration sites were detected in F1 generation. Please note that in lane 1 and 3 genomic DNA was not fully digested and presents and extra band (upper band) that does not allow seeing properly the true integration site seen in lane 5 (middle band). F4 mice used for this work had an only integration site of the transgene (lanes 4 and 6) 
a)

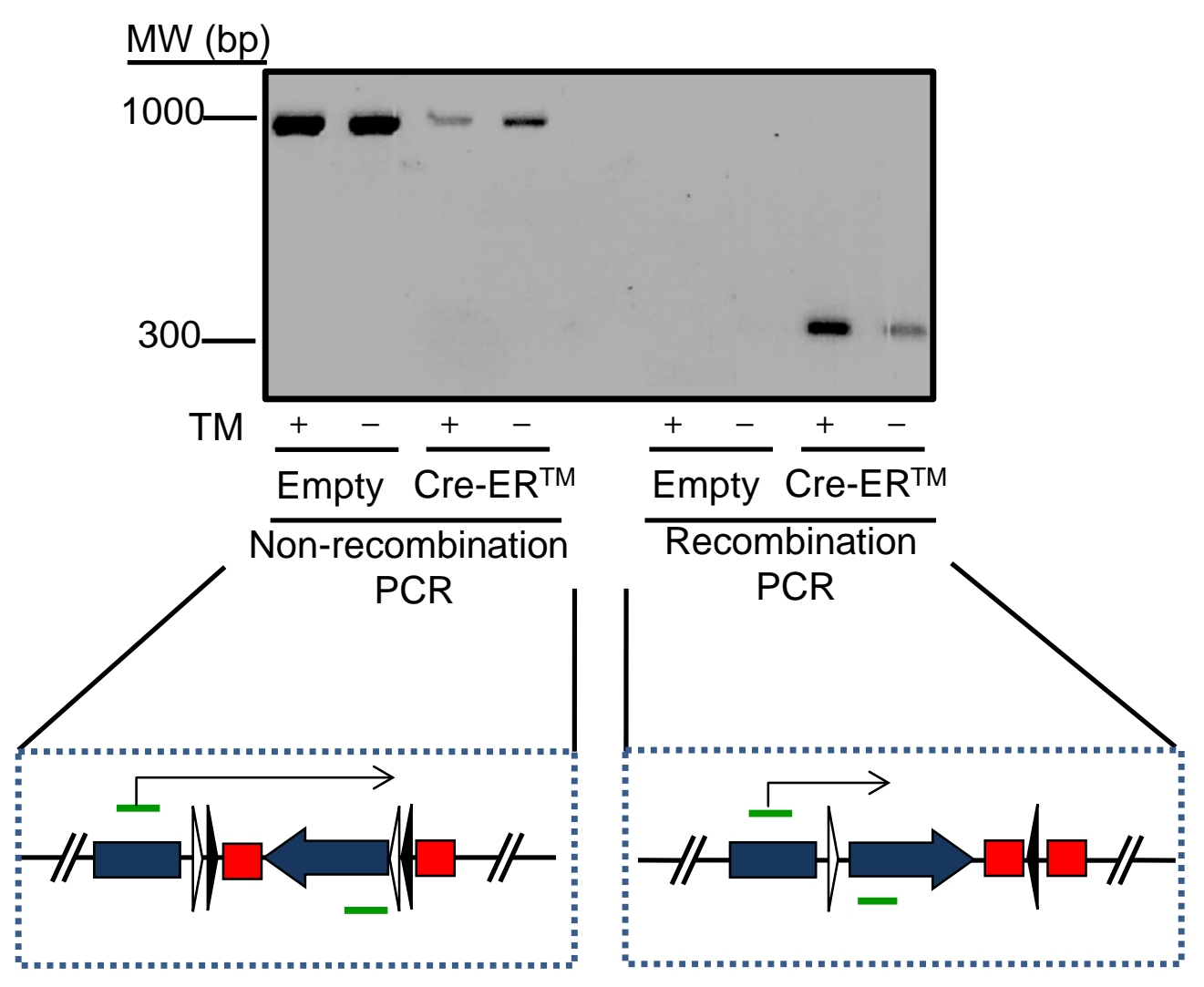

b)

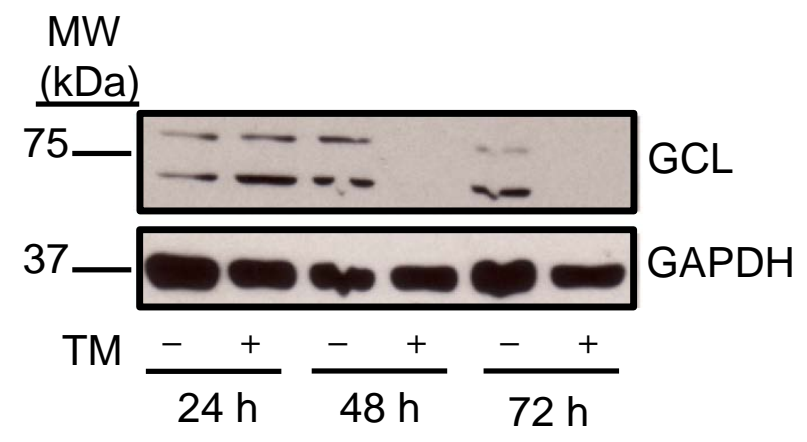

Figure 9. DNA recombination and GCL protein knockdown are successfully achieved in shGCL floxed_3-derived MEFs by Cre CDNA expression. shGCL floxed-3-derived MEFs were transfected with $\mathrm{pCMV-CreER^{TM }}$ or empty vector. Six hours after transfection, 4-hydroxy-tamoxifen (TM; $1 \mu \mathrm{M})$, or vehicle, was added. a) DNA is successfully recombined. Total DNA isolated from MEFs $24 \mathrm{~h}$ after TM addition was subjected to PCR analysis to confirm recombination. Robust bands corresponding to the non-recombined status ( 1,000 bp) were observed in MEFs transfected with the empty vector, whereas much weaker bands were observed in CreER ${ }^{T^{M}}$-transfected cells; TM-treated CreER ${ }^{T M}$ transfected cells showed the weakest band. A robust band corresponding to the recombined status ( $\sim 300 \mathrm{bp}$ ) was observed in TM treated CreER ${ }^{\mathrm{TM}}$-transfected cells, whereas a very weak band was observed in vehicle-treated CreER ${ }^{\mathrm{TM}}$ transfected cells. Please, note the primers (green lines) location in the nonrecombined or recombined constructs. b) GCL protein is successfully knockdown. Total protein extracts subjected to western blotting show GCL knockdown in TM-treated, CreER ${ }^{\mathrm{TM}}$ transfected cells after $48 \mathrm{~h}$ and $72 \mathrm{~h}$. 
a)

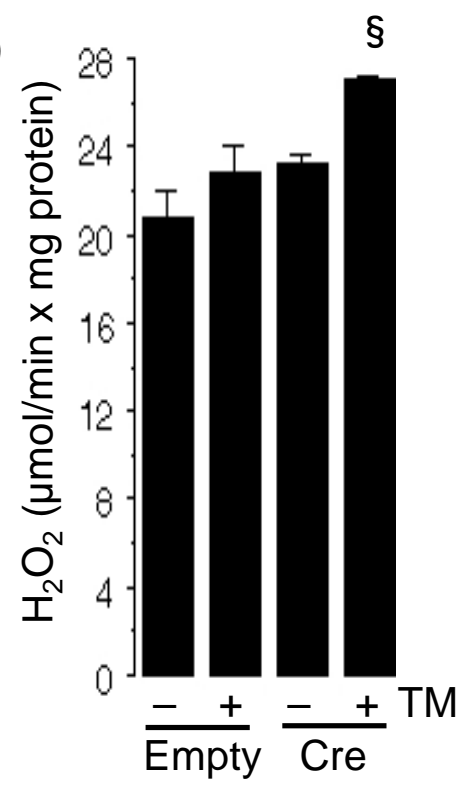

c)

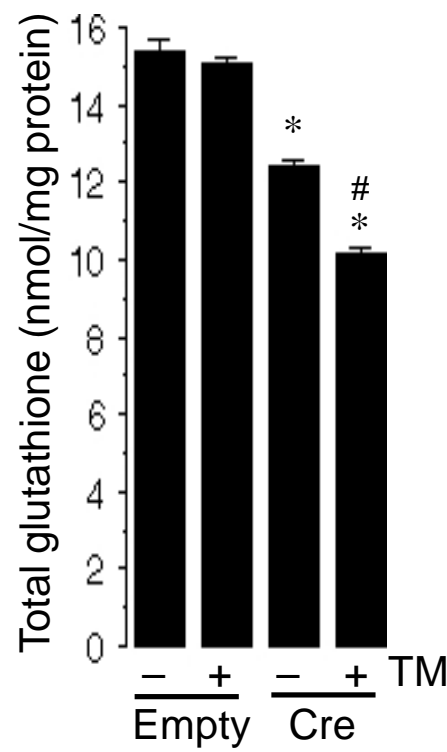

b)

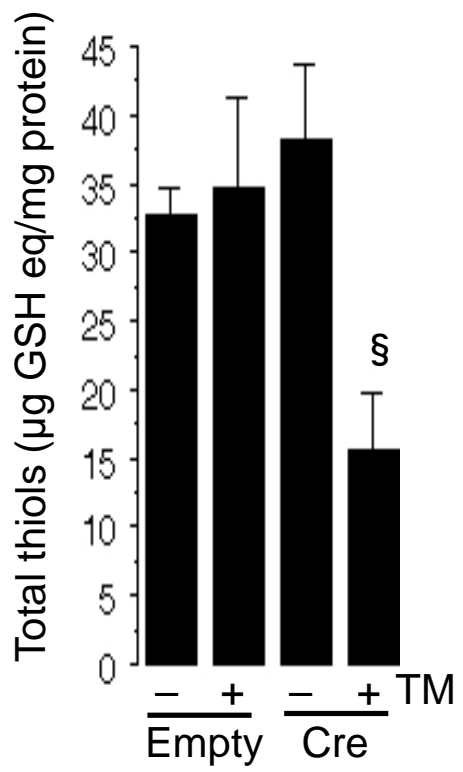

d)

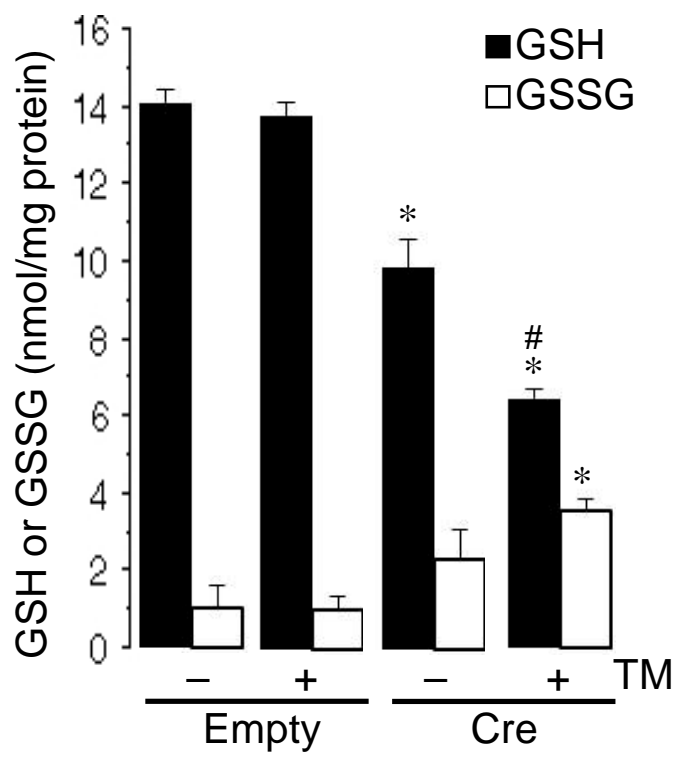

Figure 10. shGCL floxed_3-derived MEFs show signs of oxidative stress upon Cre-mediated recombination. ShGCL floxed -3 -derived MEFs were transfected with pCMV-CreER ${ }^{\mathrm{TM}}$ or empty vector. Six hours after transfection, 4-hydroxy-tamoxifen (TM; $1 \mu \mathrm{M})$, or vehicle, was added and cells analysed $24 \mathrm{~h}$ later. a) Rate of $\mathbf{H}_{2} \mathbf{O}_{2}$ detection. TM treatment had no effect on the rate of $\mathrm{H}_{2} \mathrm{O}_{2}$ detection unless cells were previously transfected with $\mathrm{CreER}^{\mathrm{TM}}$. b) Total thiols concentration. TM treatment had no effect on the concentration of total thiols unless cells were previously transfected with $C r e E R^{T M}$. c) Total glutathione concentration. Transfection of cells with CreER ${ }^{\mathrm{TM}}$ slightly decreased total glutathione concentration; TM further decreased total glutathione concentration in CreER ${ }^{\mathrm{TM}_{-} \text {, }}$ but not in empty vector-transfeced cells. d) Reduced (GSH) and oxidized (GSSG) glutathione concentrations. Transfection of cells with CreER ${ }^{\mathrm{TM}}$ slightly decreased GSH concentration; TM further decreased GSH, and increased GSSG concentrations in CreER ${ }^{\mathrm{TM}}$-, but not in empty vector-transfected cells. $\S p \leq 0.05$ vs no TM; ${ }^{*} \leq \leq 0.05$ vs empty; \#p $\leq 0.05$ vs no TM (ANOVA; $n=3$ ). 

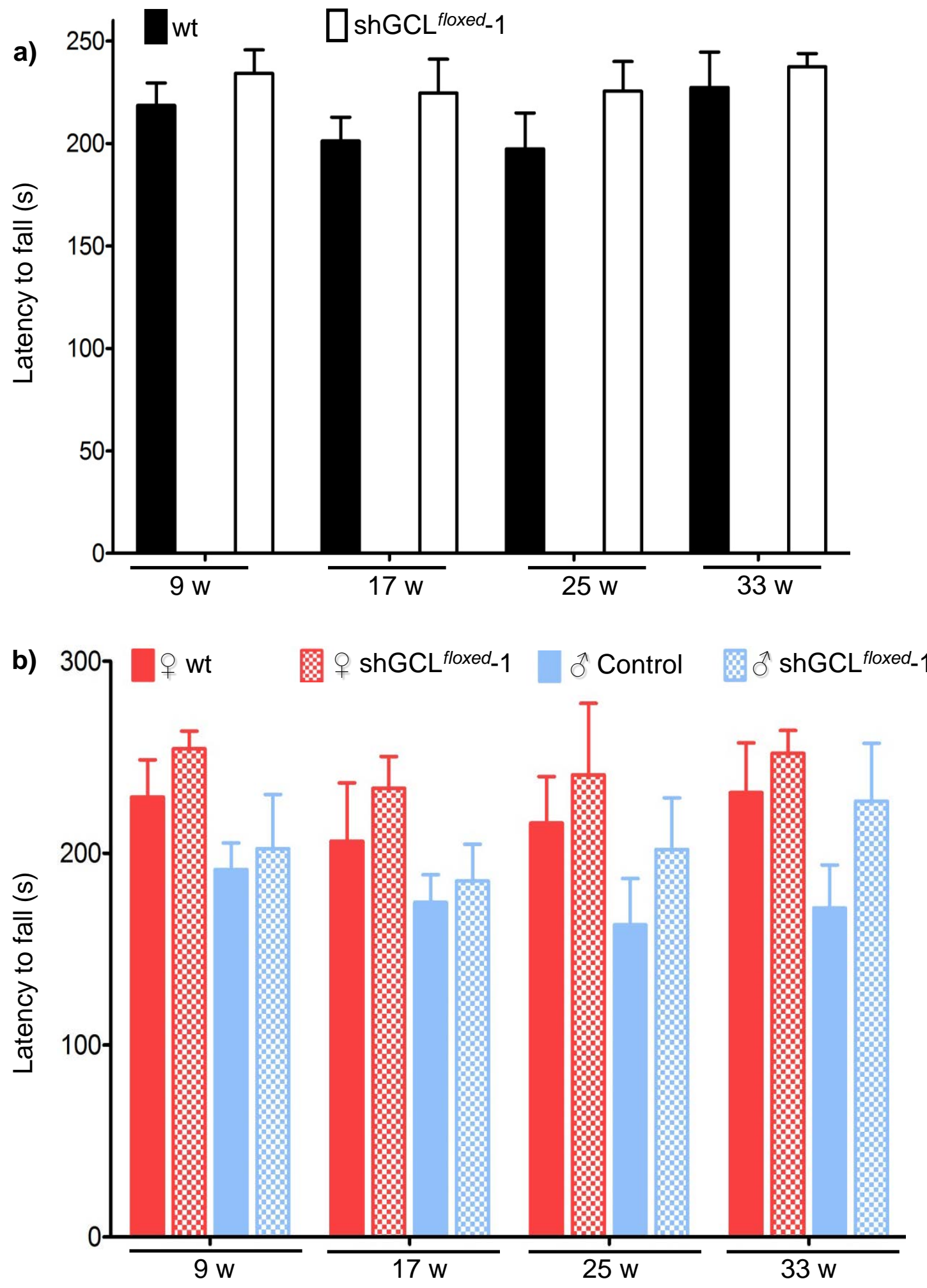

Figure 11. Motor balance and coordination is not impaired in shGCL floxed subline 1 (shGCL floxed-1) mice. Latency to fall in seconds from an accelerating rod (Rotarod) was measured in female and male mice at 9, 17, 25 and 33 weeks of age from wild type shGCL(-/-) (control) and shGCL(+/-) mice. a) Data displayed by genotype $(n \geq 10)$. b) Data displayed by sex and genotype $(n \geq 5)$. No significative results were found (Student's $t$ test). 

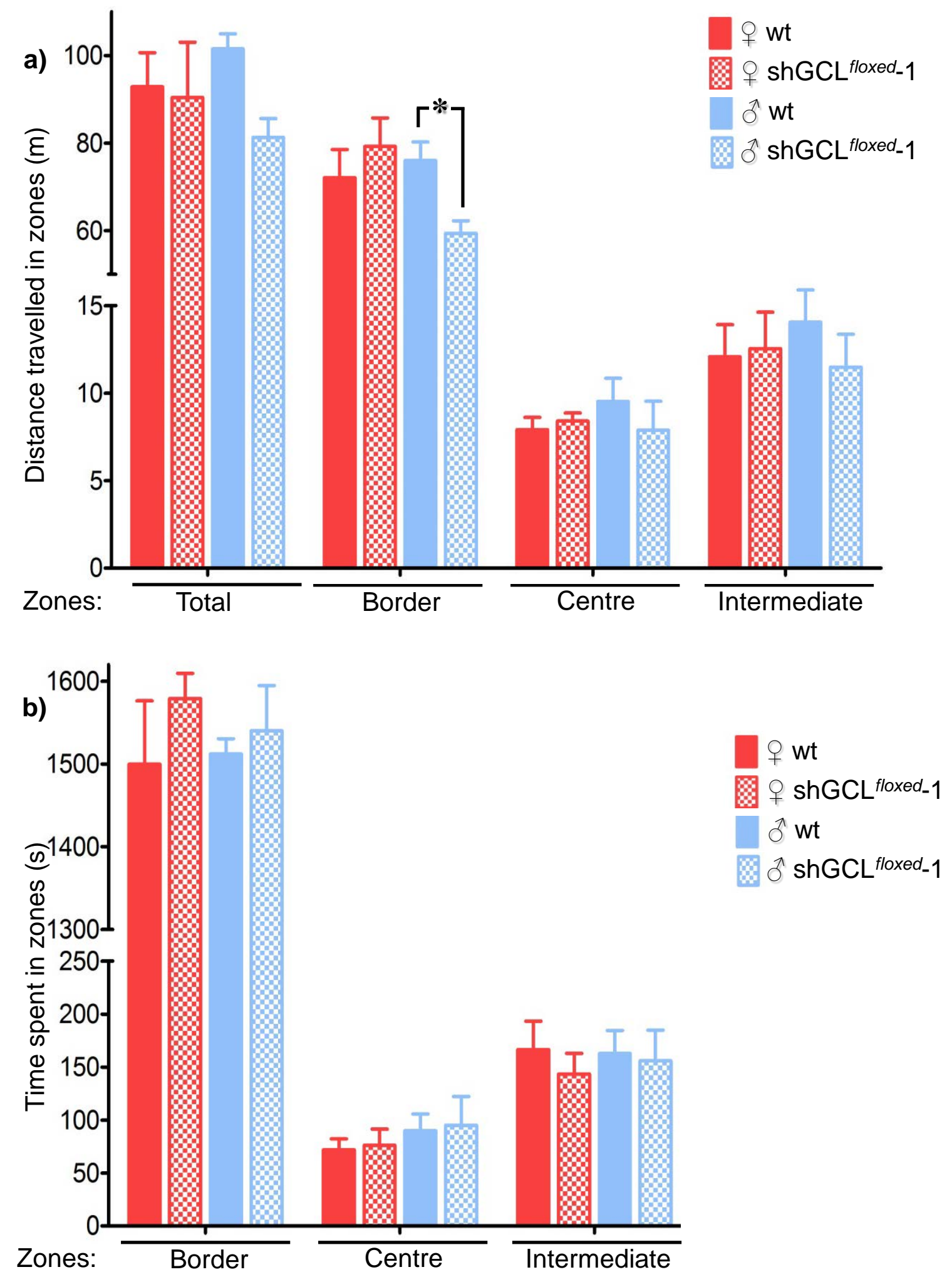

Figure 12. Fearlanxiety behaviour alteration is ambiguous in shGCL floxed subline 1 (shGCL floxed $_{-1}$ ) mice according to the Open Field test. The Open Field test was measured in mice at 11 weeks of age wild type shGCL(-/-) (control) and shGCL(+/-) mice ( $\mathrm{n} \geq 5$ each). a) Distance (in metres) travelled in each zone during 30 minutes. b) Time (in seconds) spent in each zone. shGCL(-/-) male mice from shGCL floxed subline 1 show differences for the distance travelled in the border zone vs control, but not differences were shown in times spent in arena zones showing ambiguous evidence for fear/anxiety behaviour (Student's $t$ test) (Y-axis scales interrupted for clarity). 


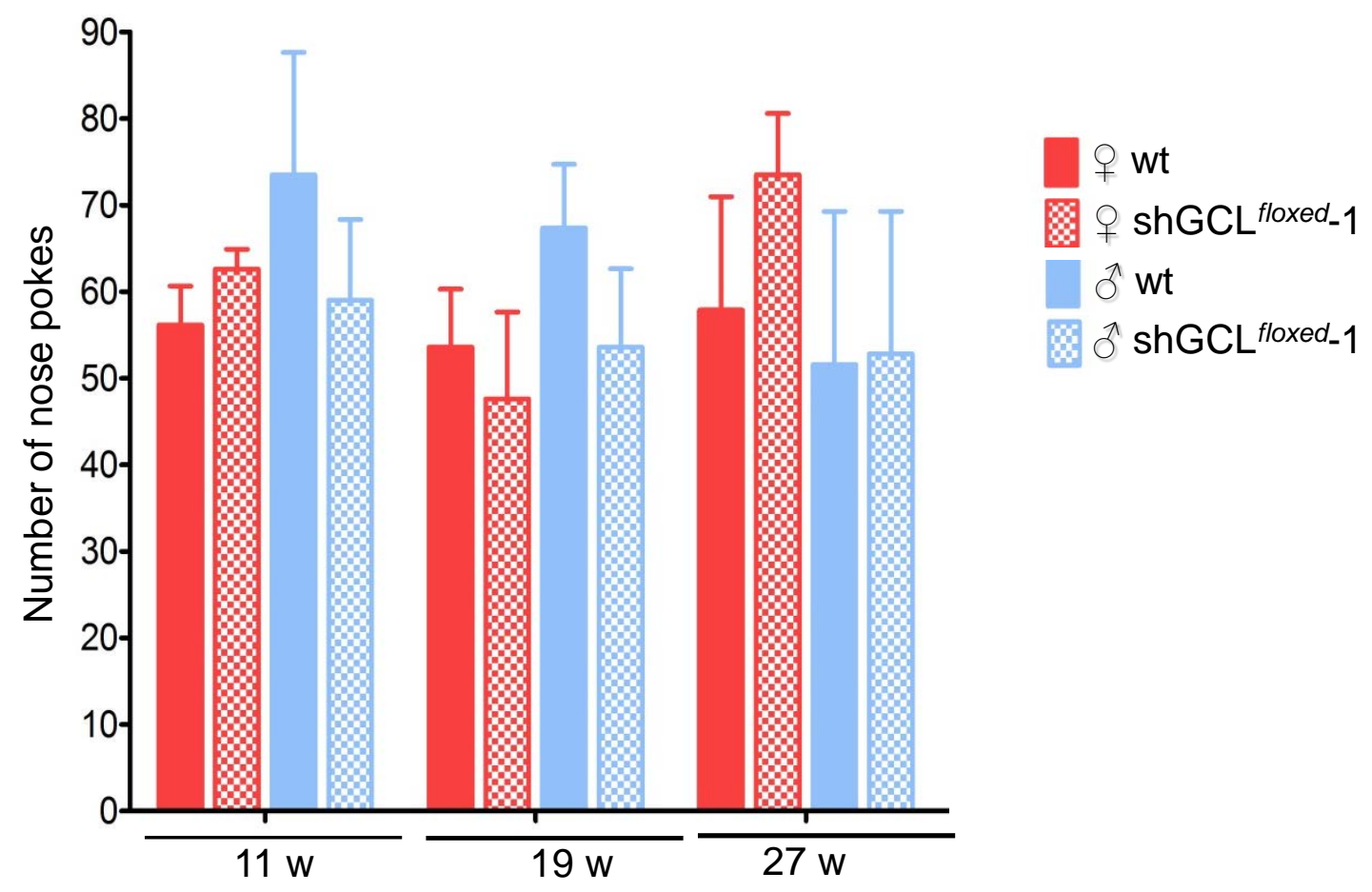

Figure 13. Fearlanxiety behaviour is not altered in shGCL ${ }^{\text {floxed }}$ (shGCL $\left.{ }^{\text {floxed }}-1\right)$ subline 1 mice. The Hole-board test was measured in mice at 11,19 and 27 weeks of age from wild type shGCL(-/-) (control) and shGCL(+/-) female and male mice ( $n \geq 5$ each). No significative results were found (Student's $t$ test). 

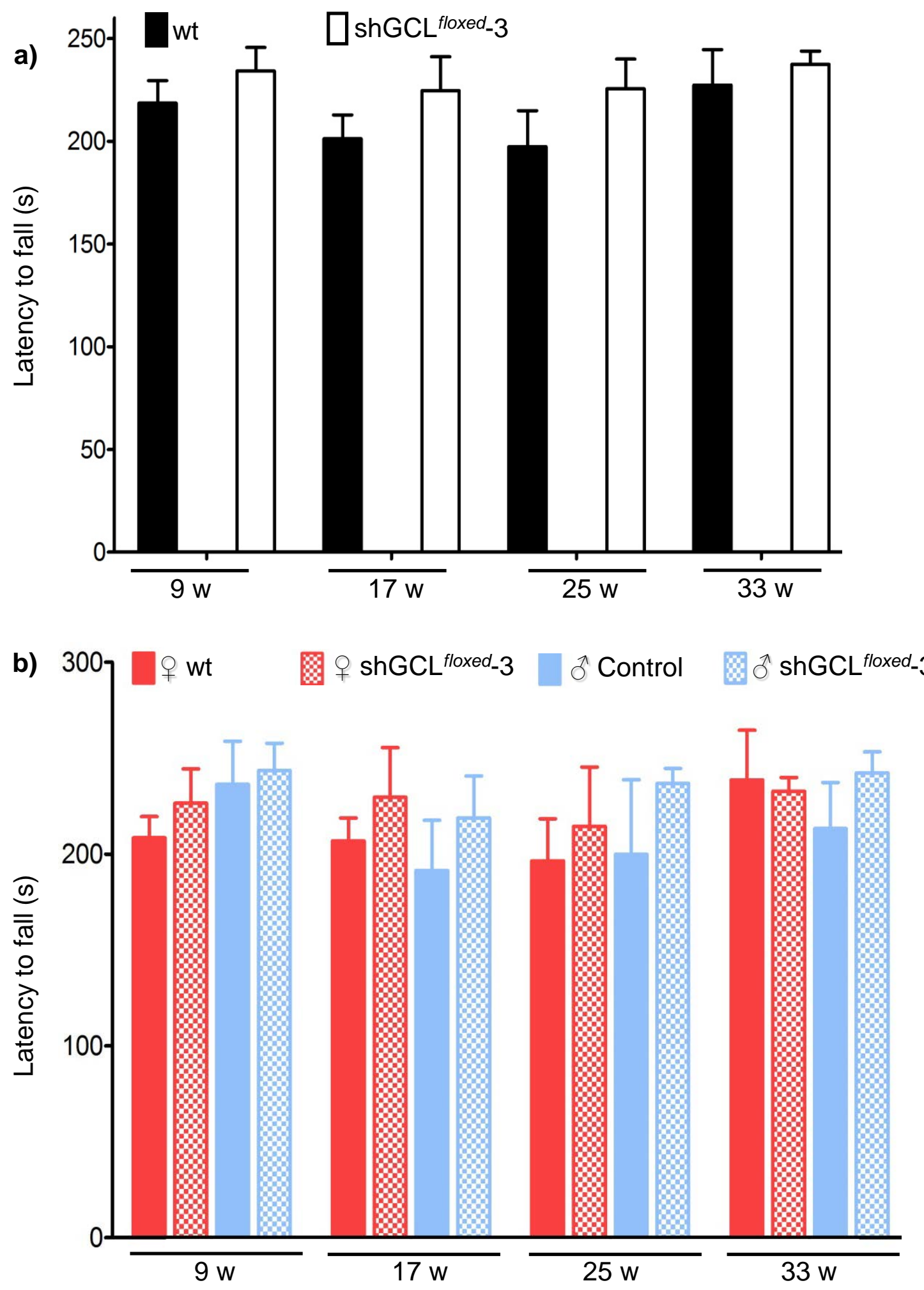

Figure 14. Motor balance and coordination is not impaired in shGCL floxed subline 3 (shGCL floxed-3) mice. Latency to fall in seconds from an accelerating rod (Rotarod) was measured in female and male mice at 9, 17, 25 and 33 weeks of age from wild type shGCL(-/-) (control) and shGCL(+/-) mice. a) Data displayed by genotype $(n \geq 10)$. b) Data displayed by sex and genotype $(n \geq 5)$. No significative results were found (Student's $t$ test). 

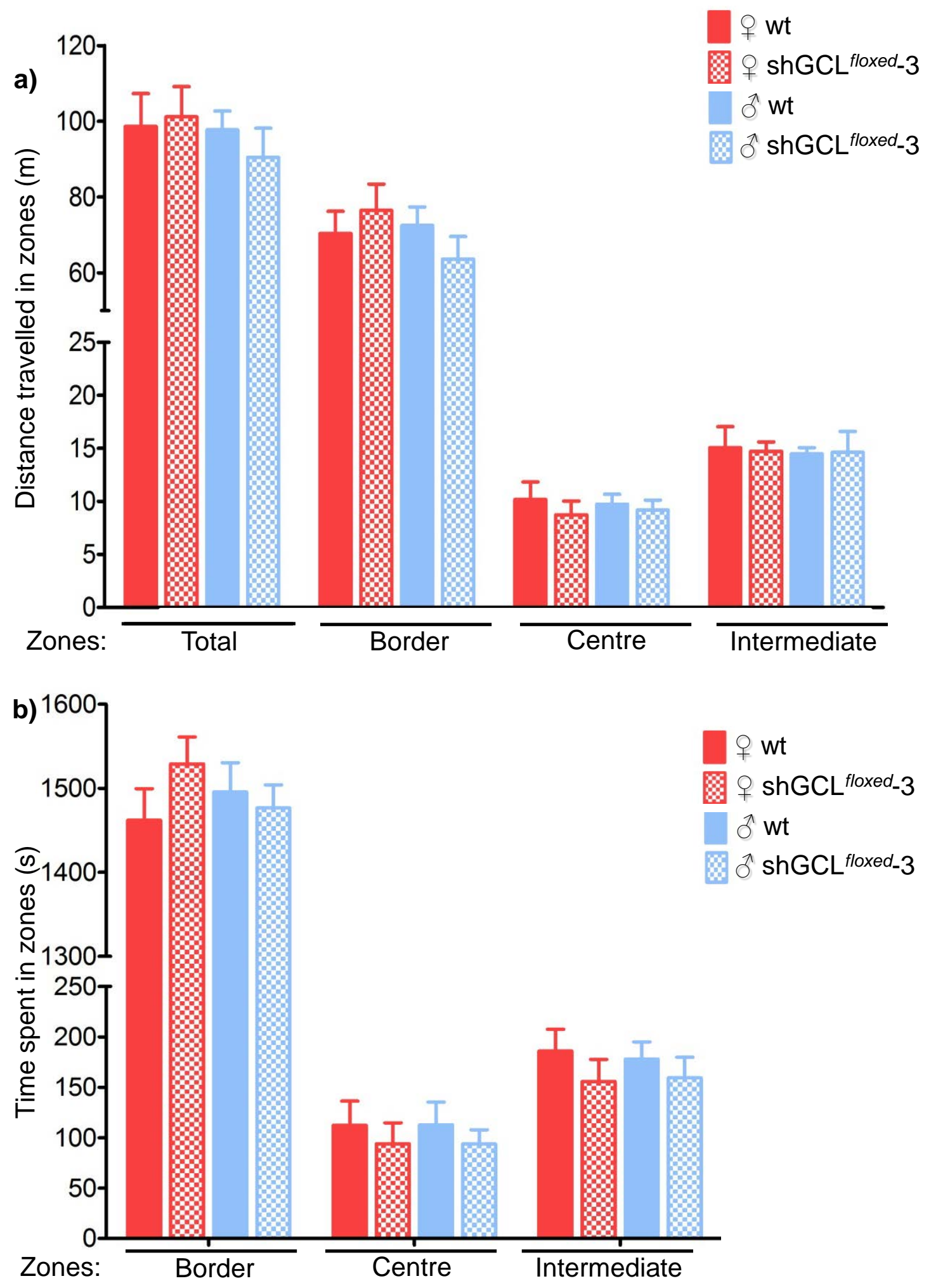

Figure 15. Fearlanxiety behaviour is not altered in shGCL floxed subline 3 (shGCL ${ }^{\text {floxed }}$-3) mice according to the Open Field test. The Open Field test was measured in mice at 11 weeks of age from wild type shGCL(-/-) (control) and shGCL(+/-) mice ( $n \geq 5$ each). a) Distance (in metres) travelled in each zone during 30 minutes. b) Time (in seconds) spent in each zone. No significative results were found (Student's $t$ test) (Y-axis scales interrupted for clarity). 


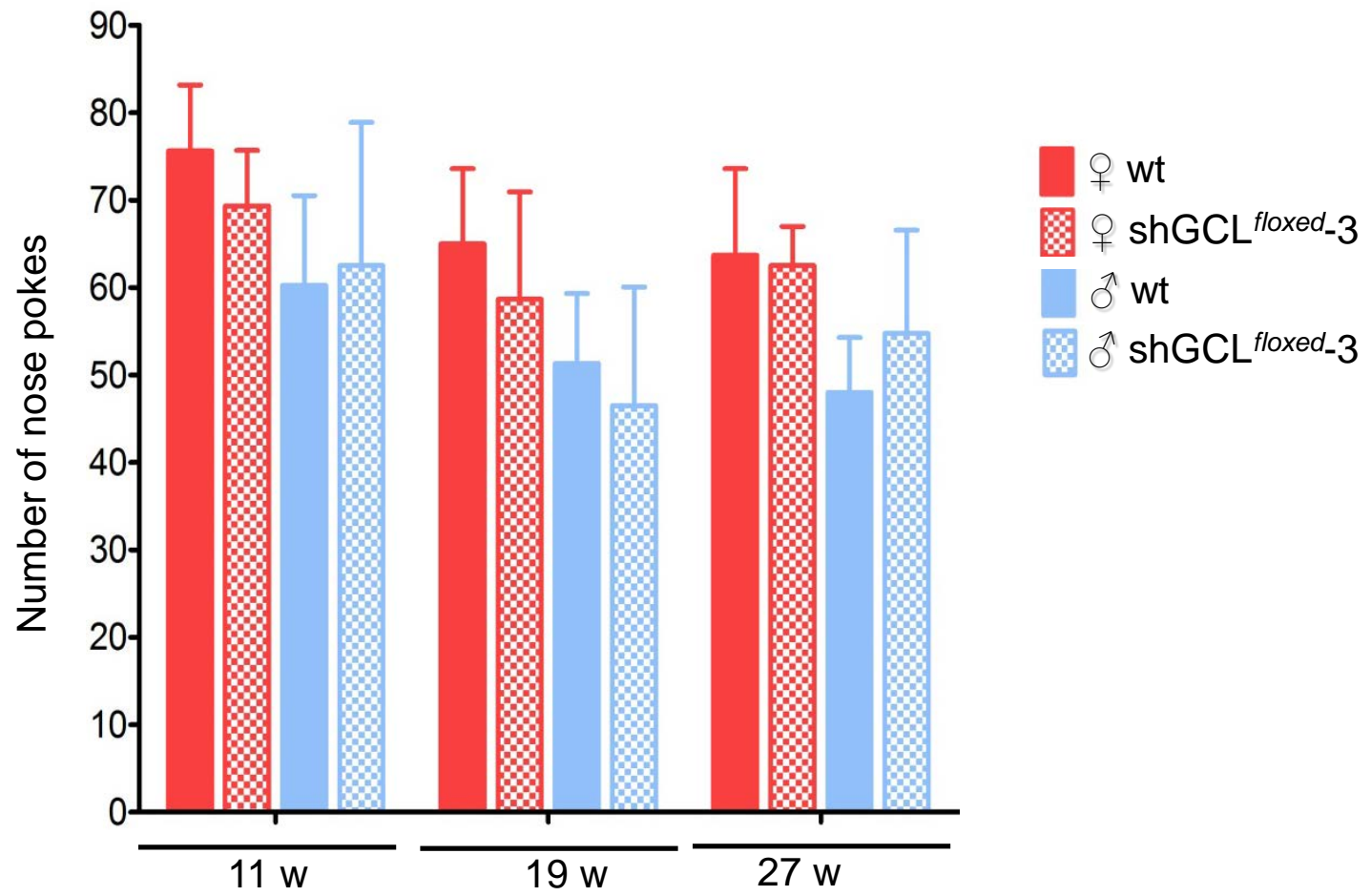

Figure 16. Fearlanxiety behaviour is not altered in shGCL floxed subline 3

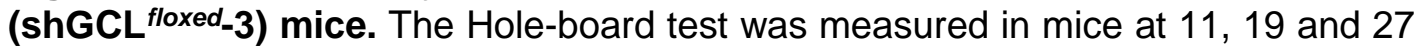
weeks of age from wild type shGCL(-/-) (control) and shGCL(+/-) female and male mice ( $n \geq 5$ each). No significative results were found (Student's $t$ test). 

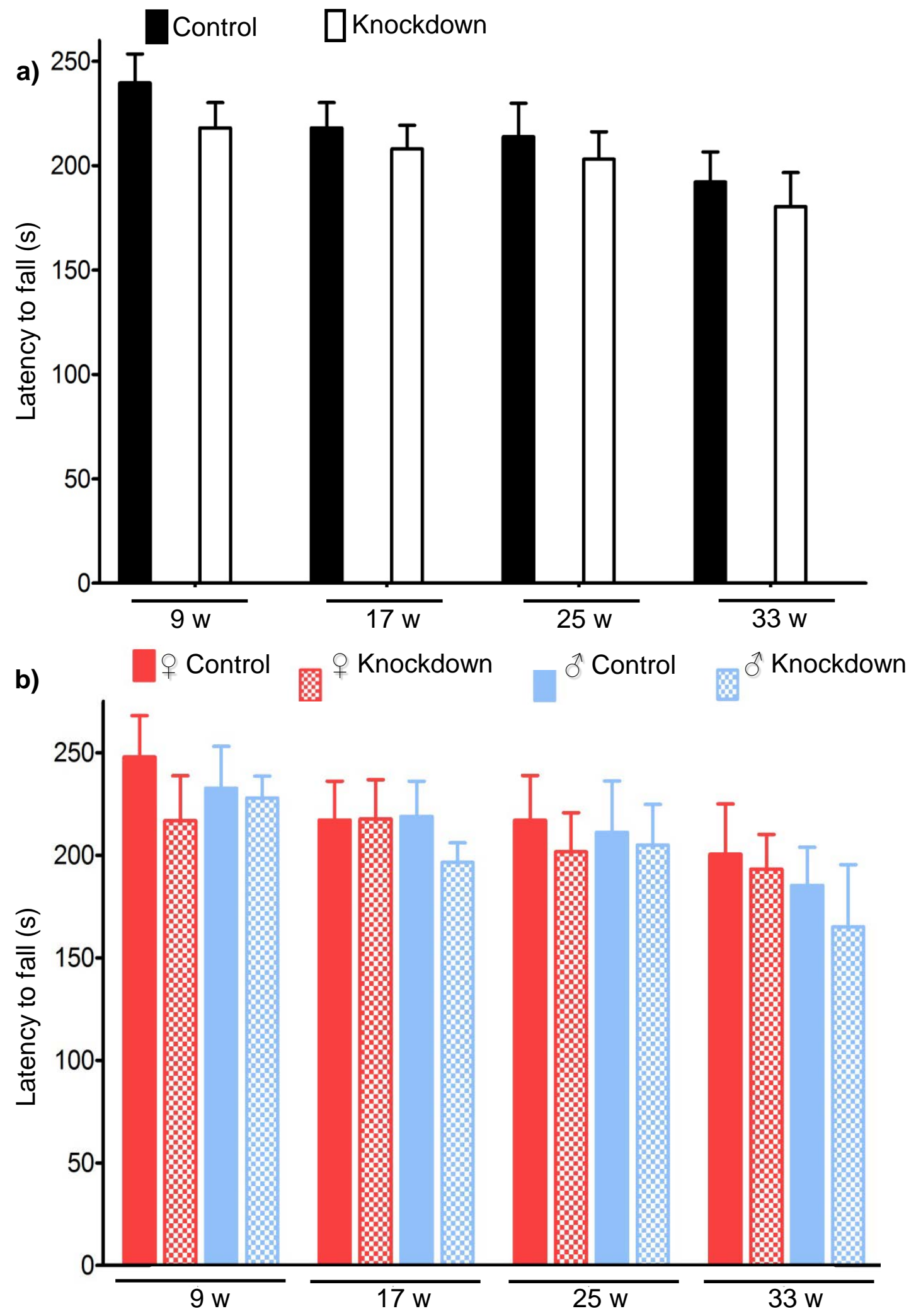

Figure 17. CamKIla-Cre/shGCL floxed -1 mice show no significative impairment in motor and balance coordination. Latency to fall in seconds from an accelerating rod (Rotarod) was measured in female and male mice at 9, 17, 25 and 33 weeks of age from subline 1 CamKIla-Cre(+/-)/shGCL(-/-) (control) and CamKIla-Cre(+/-)/shGCL(+/-) (knockdown) mice. a) Data displayed by genotype $(n \geq 10)$. b) Data displayed by sex and genotype $(n \geq 5)$. No significative results were found (Student's $t$ test). 

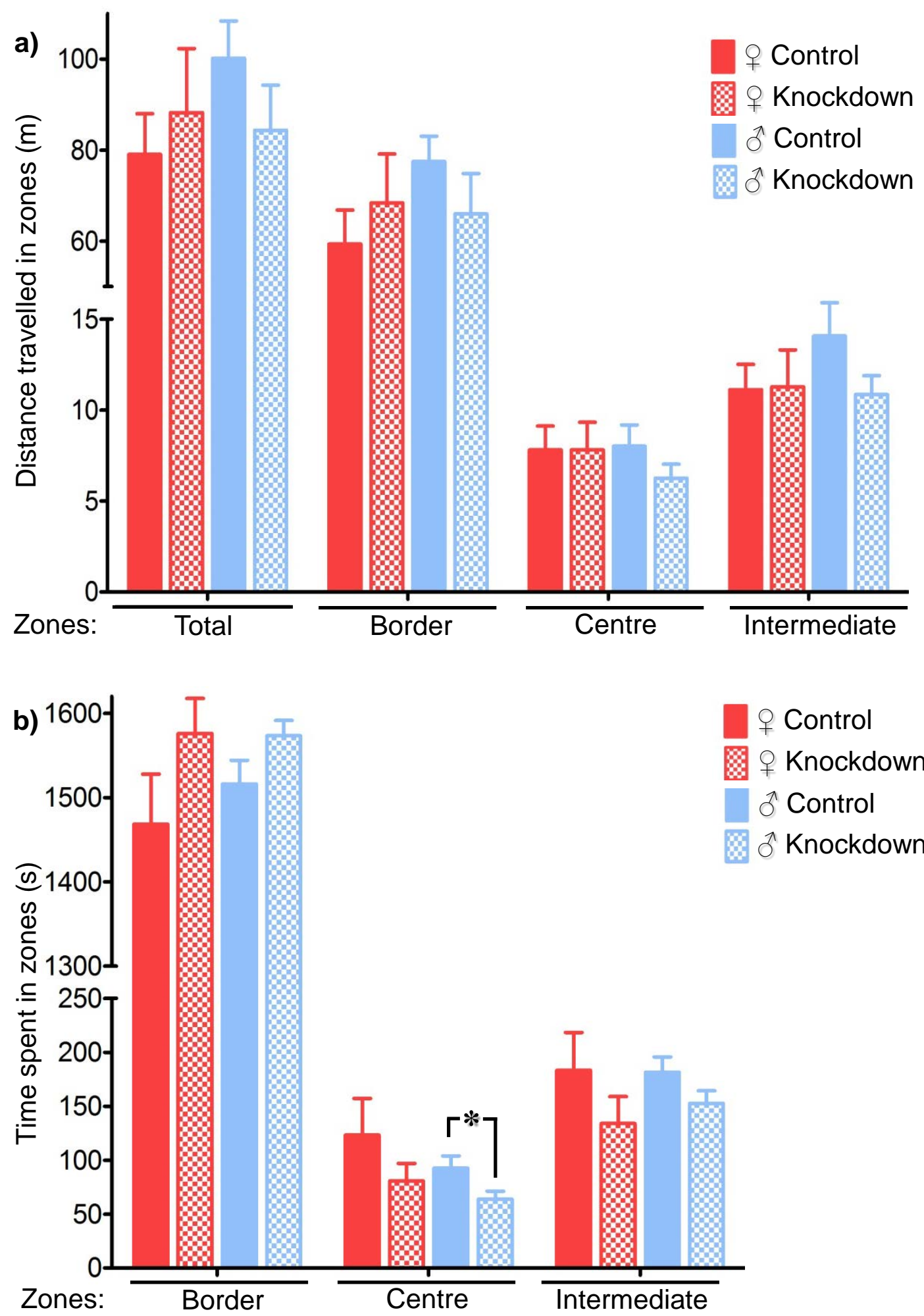

Figure 18. Male CamKIllo-Cre/shGCL floxed 1 mice appear to have fearlanxiety according to the Open Field test. The Open Field test was measured in mice at 11 weeks of age from CamKIl $\alpha-\mathrm{Cre}(+/-) / \mathrm{shGCL}(-/-)$ (control) and CamKIl $\alpha-\mathrm{Cre}(+/-$ )/shGCL(+/-) (knockdown) female and male mice ( $n \geq 6$ each). a) Distance (in metres) travelled in each zone during 30 minutes. b) Time (in seconds) spent in each zone. Please, note that knockdown males showed an increase in fear/anxiety as revealed by time spent in the centre zone, but not in the distance travelled in the centre zone. ${ }^{*} p \leq 0.05$ (Student's $t$ test). (Y-axis scales interrupted for clarity). 


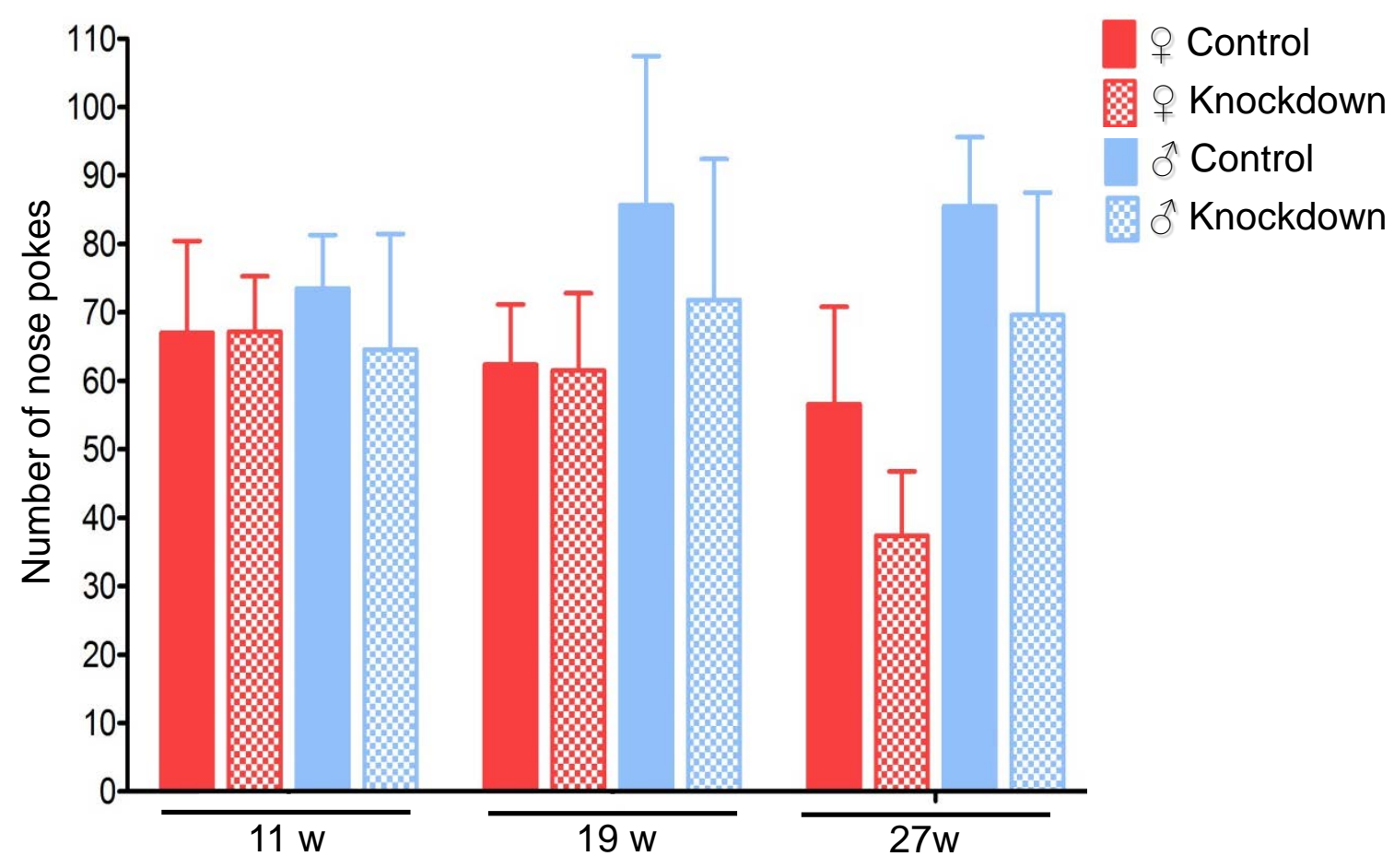

Figure 19. CamKIl $\alpha$-CrelshGCL floxed -1 mice do not show fearlanxiety, according to the Hole-board test. The Hole-board test was measured in mice at 11, 19 and 27 weeks of age from CamKIla-Cre(+/-)/shGCL(-/-) (control) and CamKIl $\alpha-$ Cre (+/-)/shGCL(+/-) (knockdown) female and male mice ( $n \geq 5$ each). No significative results were found (Student's $t$ test), though a decrease in exploratory behaviours (nose pokes) can be see for female knockdown mice at 27 weeks 

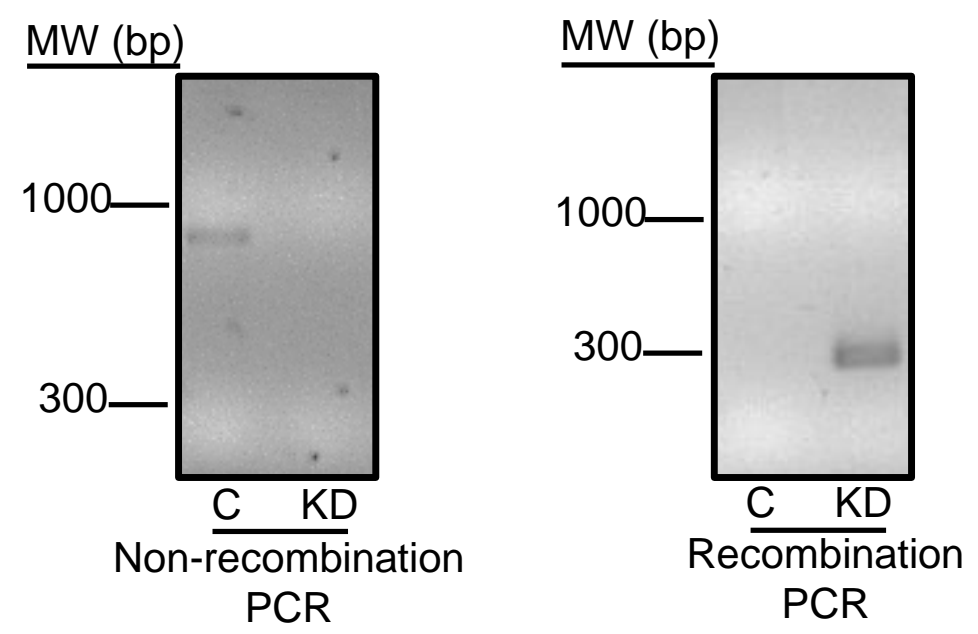

Figure 20. shGCL floxed-3 mouse is successfully recombined in the hippocampus after crossing with the CamKIl $\alpha$-Cre mouse in vivo. The brains were extracted from aged (40 week-old) CamKIl $\alpha-C r e / s h G C L^{\text {floxed }}-3$ mice and the hippocampus dissected for DNA isolation and genotyping. The genotypes used were CamKIl $\alpha-\mathrm{Cre}(+/-) / \mathrm{shGCL}(-/-)$ (defined as control, C) and CamKIl $\alpha-C r e(+/-$ )/shGCL(+/-) (defined as knockdown; KD). Gels are shown in inverted color to improve visualization. As shown in the left panel, the band corresponding to the no recombined status $(\sim 1,000 \mathrm{pb})$ was detected in $\mathrm{C}$, but not in KD mice. As shown in the right panel, the band corresponding to the recombined status ( $\sim 300$ $\mathrm{pb}$ ) was observed in $\mathrm{KD}$, but not in $\mathrm{C}$ mice. Please, see Figure 8.a for the location of the primers used. 


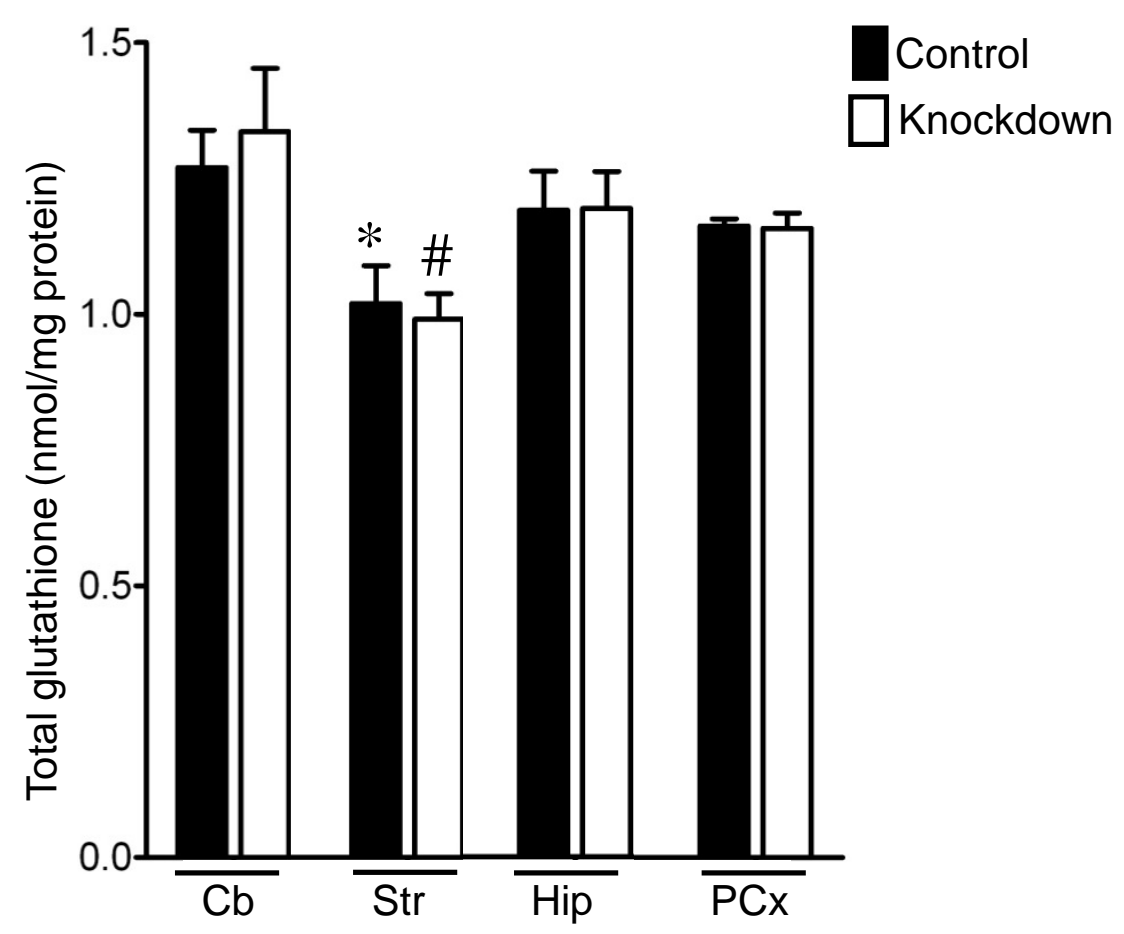

Figure 21. A decrease in total glutathione concentration is not detected in brain tissue from CamKIl $\alpha$-CrelshGCL ${ }^{\text {floxed }}-3$ mice in vivo. The brains were extracted from aged (40 week-old) CamKIl $\alpha-\mathrm{Cre}(+/-) / \mathrm{shGCL}(-/-)$ (control) and CamKIl $\alpha-C r e(+/-) /$ shGCL(+/-) (knockdown) mice and dissected into cerebellum (Cb), striatum (Str), hippocampus (Hip) and prefrontal cortex (PCx). These samples -containing a mixture of all brain cell types- were subjected to total glutathione determination. As shown, no differences in total glutathione concentration was found between control and knockdown groups in any of the areas determined. Noticeably, total glutathione concentration was found to be significantly lower in the striatum of these mice -regardless the genotype- when compared with the rest of the brain areas analysed. ${ }^{*} p \leq 0,05 \mathrm{vs}$ control in the other brain areas; $\# p \leq 0,05$ vs knockdown in the other brain areas (ANOVA; $n=3$ ). 
a) Females $\frac{\mathrm{Cb}}{\mathrm{CKD}} \frac{\mathrm{Str}}{\mathrm{CKD}} \frac{\mathrm{Hip}}{\mathrm{C} \mathrm{KD}} \frac{\mathrm{PCx}}{\mathrm{CKD}}$
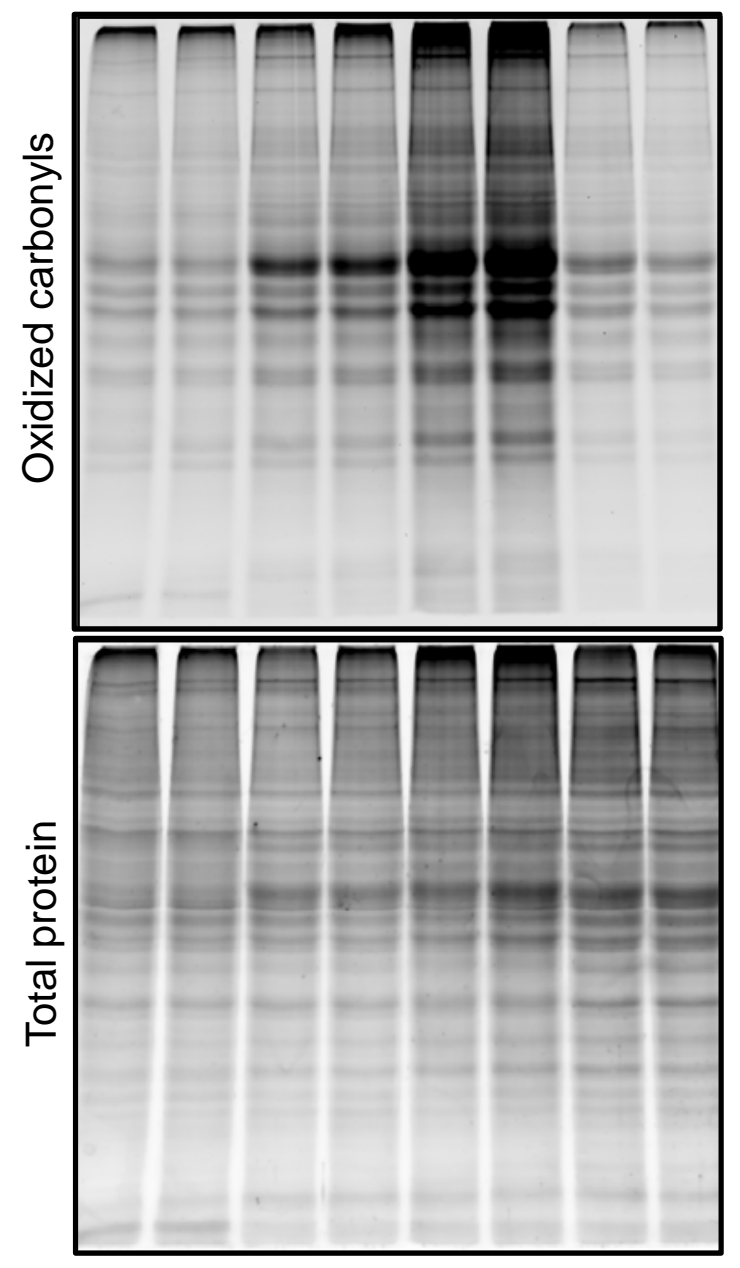

b) Males $\frac{\mathrm{Cb}}{\mathrm{CKD}} \frac{\mathrm{Str}}{\mathrm{CKD}} \stackrel{\mathrm{Hip}}{\mathrm{C} \quad \mathrm{KD}} \frac{\mathrm{PCx}}{\mathrm{C} K D}$

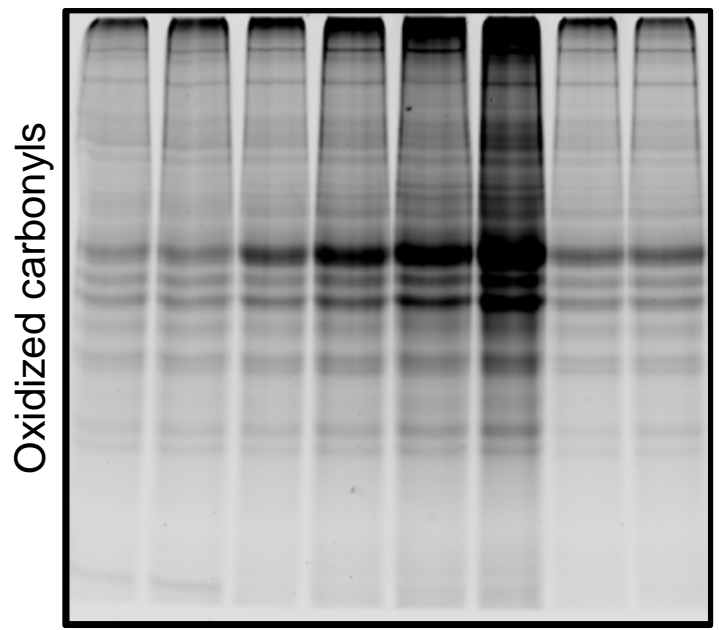

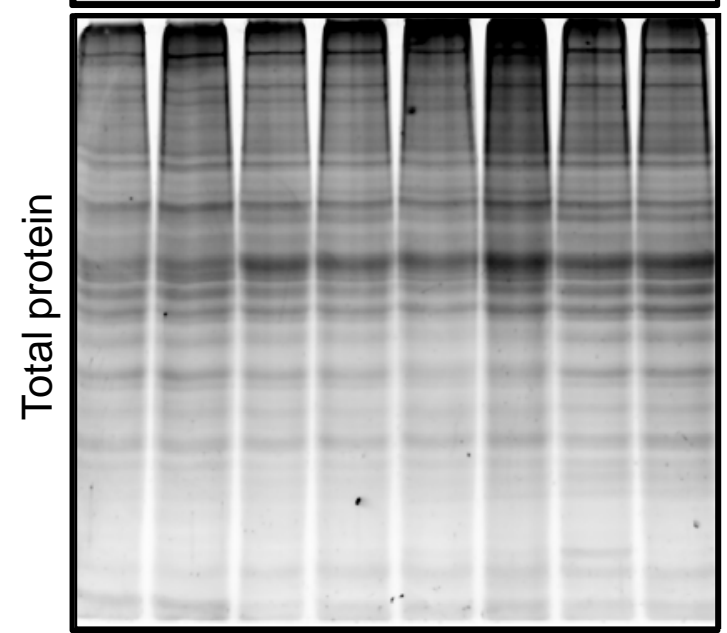

Figure 22. CamKIlo-Cre/shGCL ${ }^{\text {floxed }}-3$ mice show increased oxidized carbonyls in vivo. The brains were extracted from aged (40 week-old) CamKIl $\alpha$ Cre(+/-)/shGCL(-/-) (control; C) and CamKlla-Cre(+/-)/shGCL(+/-) (knockdown; $\mathrm{KD}$ ) mice and dissected into cerebellum (Cb), striatum (Str), hippocampus (Hip) and prefrontal cortex (PCx). These samples were subjected to oxidized protein carbonyls detection (upper panel) and total protein abundance (lower panel) in females (a) and males (b). As shown in a, the hippocampus of knockdown females present higher carbonyls oxidation than controls. In males (b) both the hippocampus and the striatum present higher carbonyls oxidation than controls. 

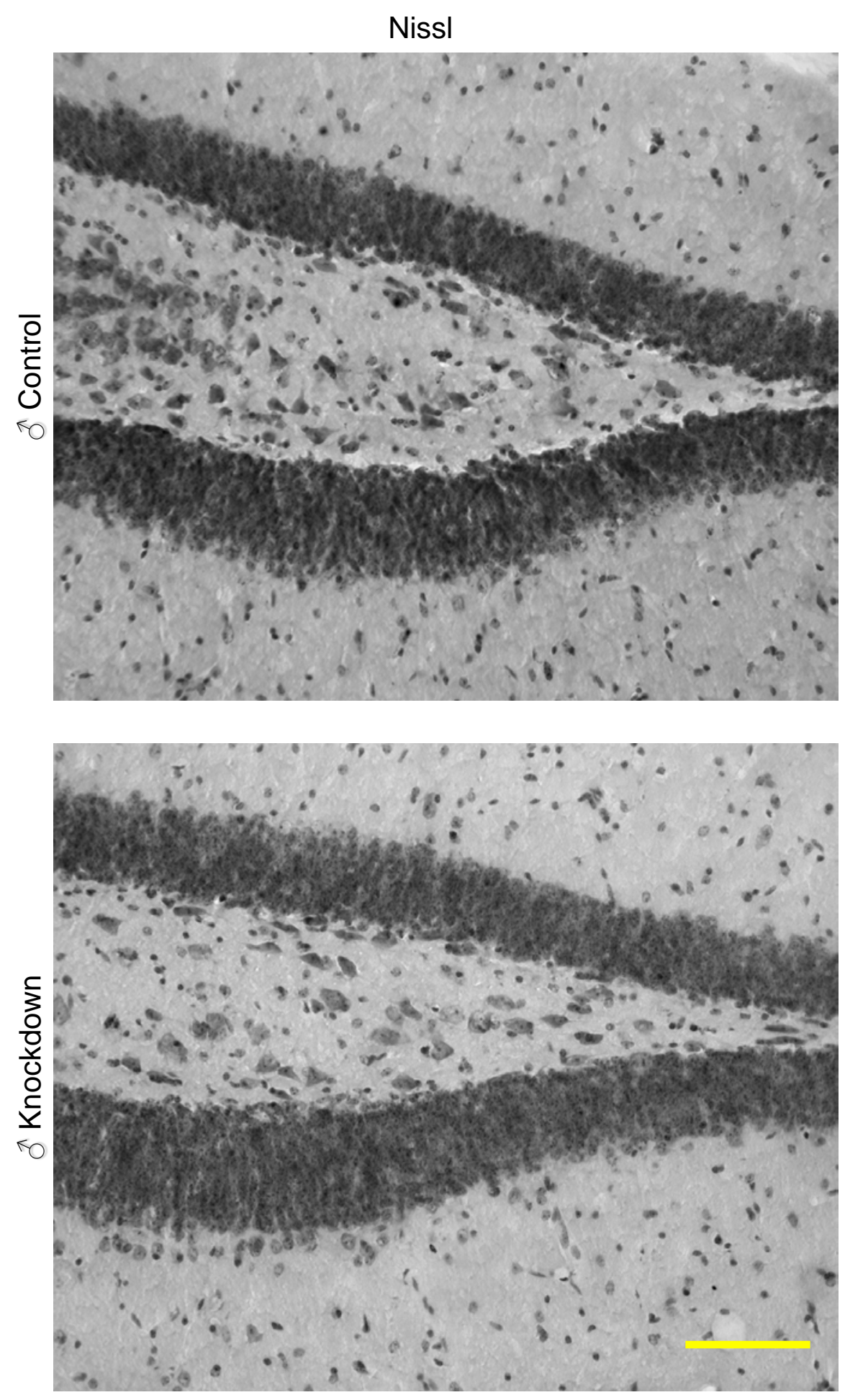

Figure 23. Nissl staining shows no detectable structural or morphological changes of the CamKIl $\alpha-$ Cre/shGCL $^{\text {floxed }-3}$ mice hippocampus. Microphotographs show hippocampal views of brain tissue from aged (40 weekold) male CamKIl $\alpha-\mathrm{Cre}(+/-) / \mathrm{shGCL}(-/-)$ (control) and CamKIl $\alpha-\mathrm{Cre}(+/-) / \mathrm{shGCL}(+/-)$ (knockdown) mice. As shown, no major structural or morphological differences between control and knockdown mice are observed. (Scale bar: $100 \mu \mathrm{m}$ ). 


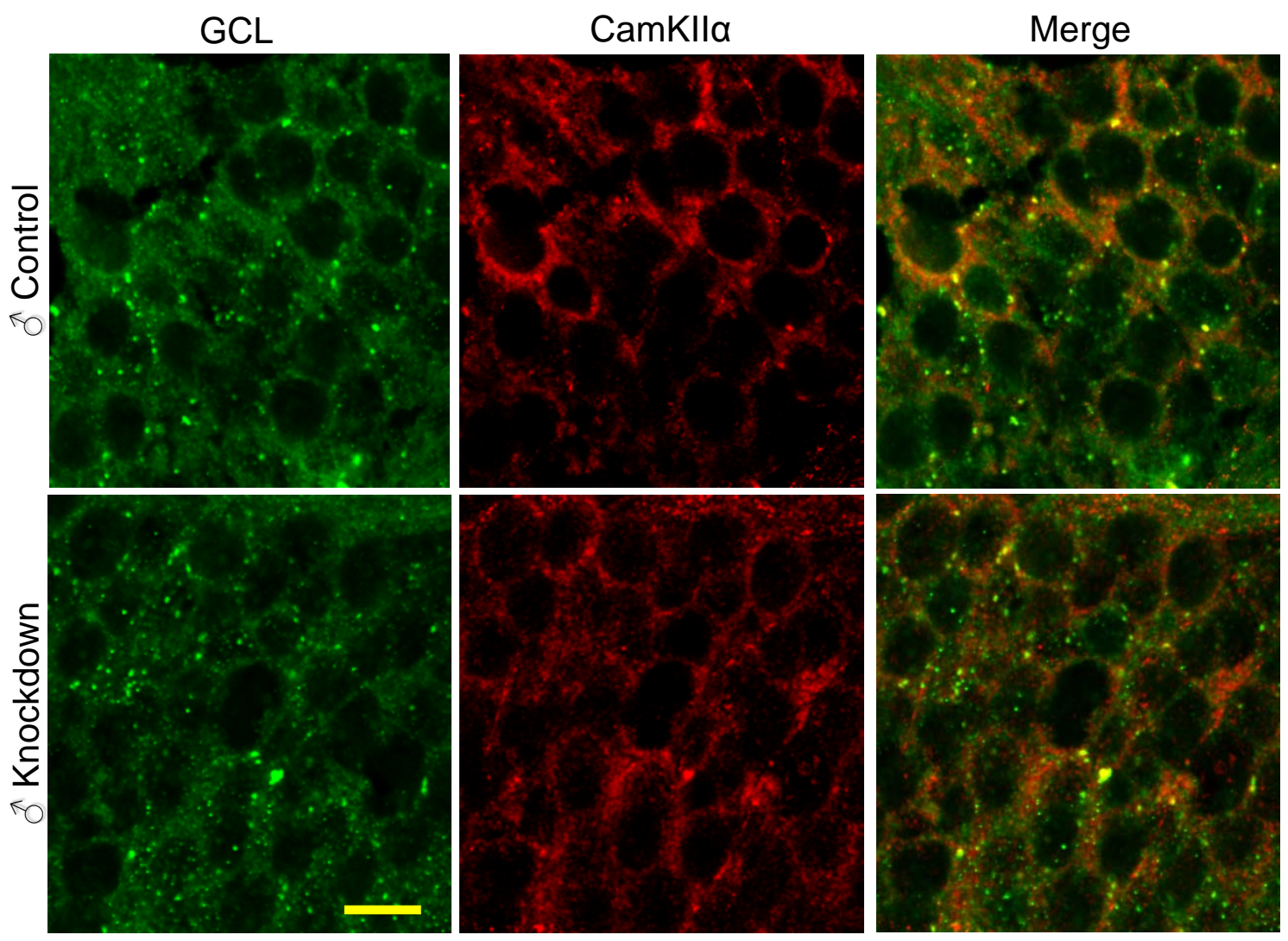

Figure 24. Low GCL protein abundance in the brain impairs immunohistochemical detection of knocked down GCL in CamKIl $\alpha$ Cre/shGCL floxed-3 mice. Confocal images of hippocampal cells of brain tissue from aged (40 week-old) male CamKIl $\alpha-C r e(+/-) /$ shGCL(-/-) (control) and CamKIl $\alpha-\mathrm{Cre}(+/-) / \mathrm{shGCL}(+/-)$ (knockdown) mice. As shown, there were no detectable differences in GCL staining between control (upper) and knockdown (lower) mice. As discussed in the text, this is possibly due to the very low detectable levels of GCL in the brain (Godoy et al., 2011). Please, note denser spots in the GCL images, which might account for either vesicular localization or aggregation of proteins. No differences in Camkll $\alpha$ staining was observed between both groups of animals. (Scale bar: $12 \mu \mathrm{m}$. Sequential acquisition of fluorescence was not necessary). 


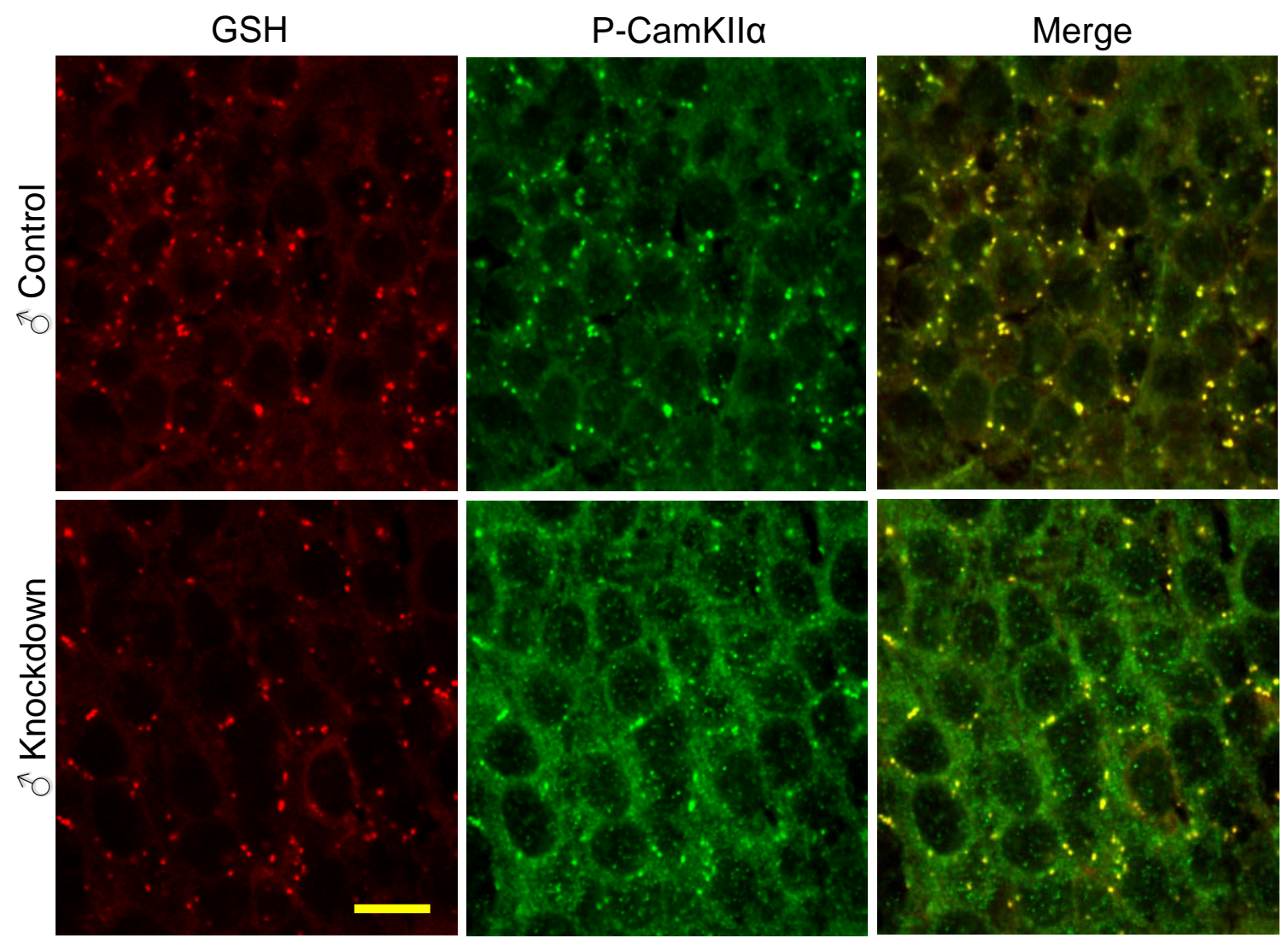

Figure 25. Decreased glutathionylated proteins and increased phosphorylated CamKIl $\alpha$ in CamKIl $\alpha-C r e / s h G C^{\text {floxed }}-3$ mice, as judged by immunohistochemistry. Confocal images of hippocampal cells of brain tissue from aged (40 week-old) male CamKIl $\alpha-C r e(+/-) /$ shGCL(-/-) (control) and CamKIl $\alpha-C r e(+/-) /$ shGCL(+/-) (knockdown) mice. The abundance of glutathionylated proteins is lower in knockdown (lower panel) when compared with control (upper panel) mice. Phospho-CamKIla (P-CamKIla) staining is higher in knockdown (lower panel) when compared with control (upper panel) mice. Please, note the denser spots throughout, which might account for either vesicular localization or aggregation of proteins, and how these spots are masked in the PCamKIla inmunostaining (possibly due to the higher intensity of staining). (Scale bar: $12 \mu \mathrm{m}$. Red and green fluorescence images were taken sequentially). 

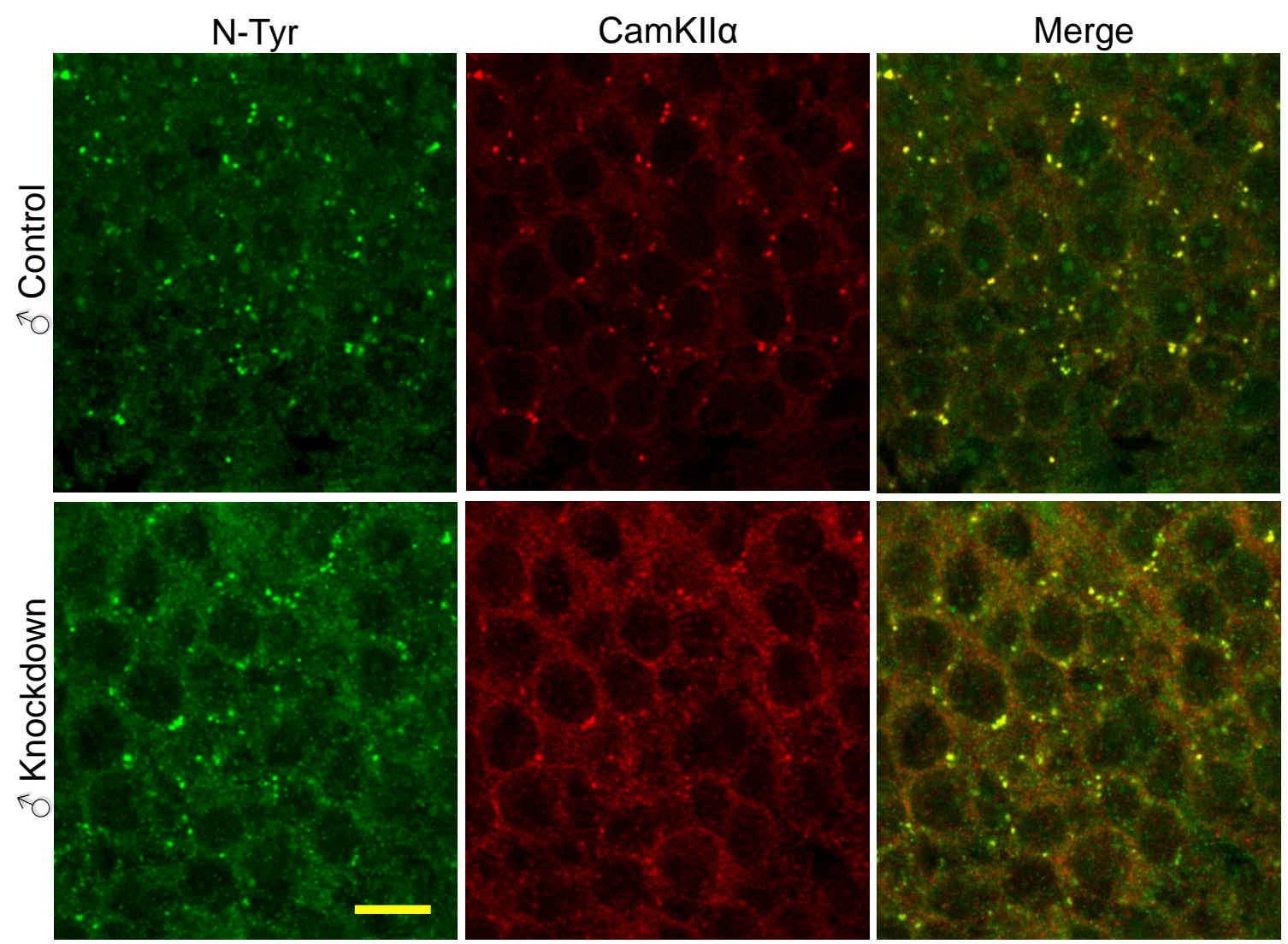

Figure 26. Increased nitrated proteins in CamKIl $\alpha-C r e / s h G C L^{\text {floxed }}-3$ mice, as judged by immunohistochemistry. Confocal images of hippocampal cells of brain tissue from aged (40 week-old) male CamKIl $\alpha-\mathrm{Cre}(+/-) / \mathrm{shGCL}(-/-)$ (control) and CamKIl $\alpha-\mathrm{Cre}(+/-) / \mathrm{shGCL}(+/-)$ (knockdown) mice. The abundance of 3nitrotyrosinated (nitrated) proteins is higher in knockdown (lower panel) when compared with control (upper panel) mice. CamKlla staining is higher in knockdown (lower panel) when compared with control (upper panel) mice. Please, note the denser spots throughout, which might account for either vesicular localization or aggregation of proteins, and how these spots are masked in the CamKIla inmunostaining (possibly due to the higher intensity of staining). (Scale bar: $12 \mu \mathrm{m}$. Red and green fluorescence images were taken sequentially). 


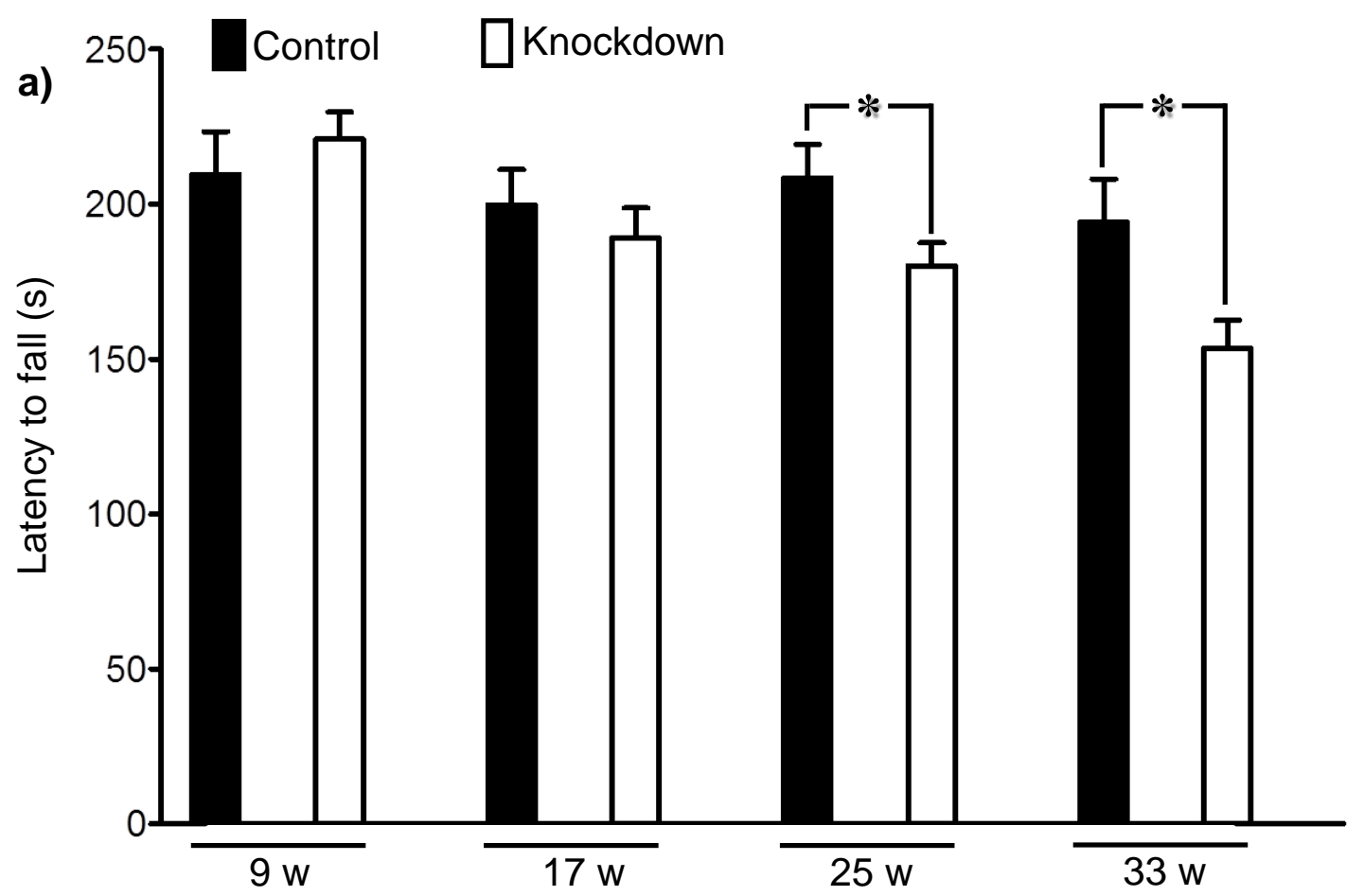

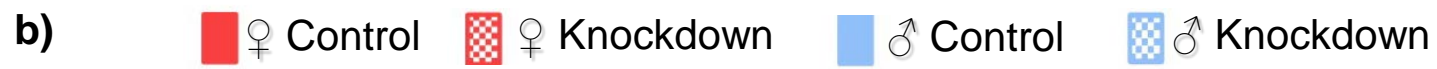

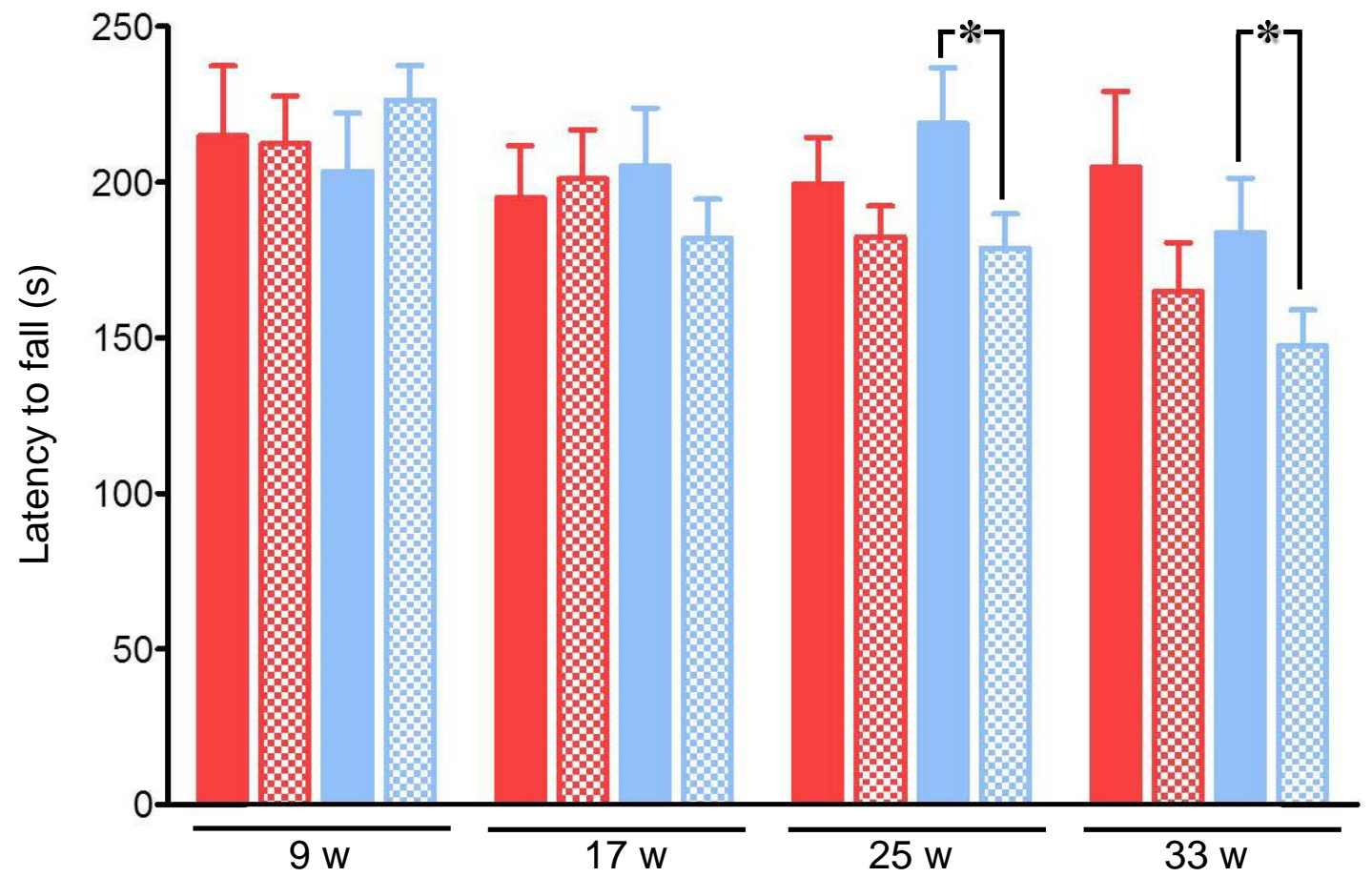

Figure 27. Motor balance and coordination is impaired in the CamKIllCre/shGCL floxed-3 mice. Latency to fall in seconds from an accelerating rod (Rotarod) was measured in female and male mice at 9, 17, 25 and 33 weeks of age from CamKIl $\alpha-\mathrm{Cre}(+/-) / \mathrm{shGCL}(-/-)$ (control) and CamKIl $\alpha-\mathrm{Cre}(+/-) / \mathrm{shGCL}(+/-)$ (knockdown) mice. a) Data displayed by genotype $(n \geq 12)$. b) Data displayed by sex and genotype $(n \geq 6)$. Please, note that the bad performances in males was a major contributing factor in knockdown impairment. *p $\leq 0.05$ (Student's $t$ test). 

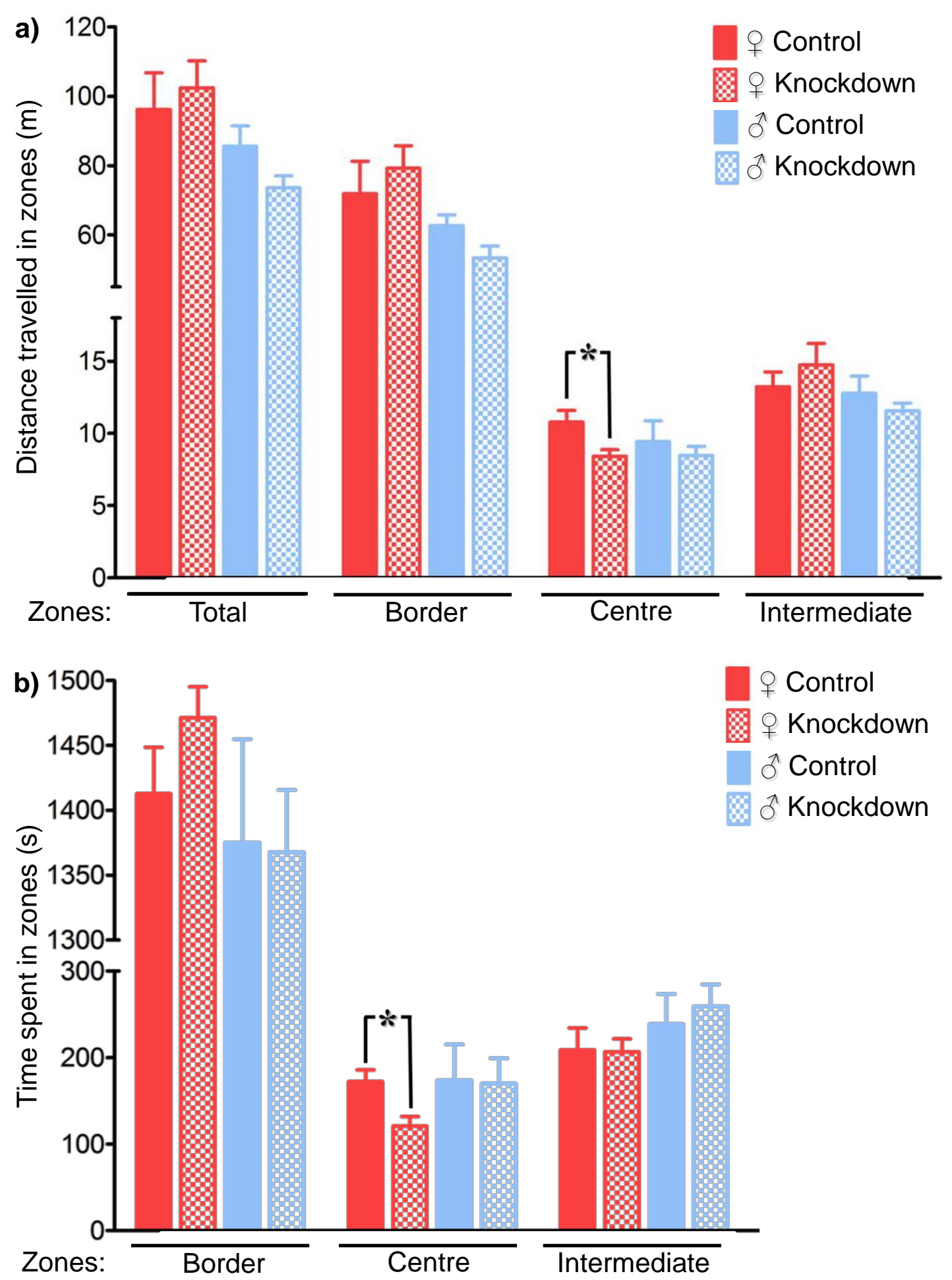

Figure 28. Female CamKIll-Cre/shGCL ${ }^{\text {floxed }}$-3 mice show fear/anxiety according to the Open Field test. The Open Field test was measured in mice at 11 weeks of age from CamKIl $\alpha-\mathrm{Cre}(+/-) / \mathrm{shGCL}(-/-)$ (control) and CamKIl $\alpha-\mathrm{Cre}(+/-$ )/shGCL(+/-) (knockdown) female and male mice ( $n \geq 6$ each). a) Distance (in metres) travelled in each zone during 30 minutes. b) Time (in seconds) spent in each zone. Please, note that knockdown females showed an increase in fear/anxiety as revealed by the decreased distance travelled and time spent in the centre zone. * ${ }^{*} \leq 0.05$ (Student's $t$ test). (Y-axis scales interrupted for clarity). 


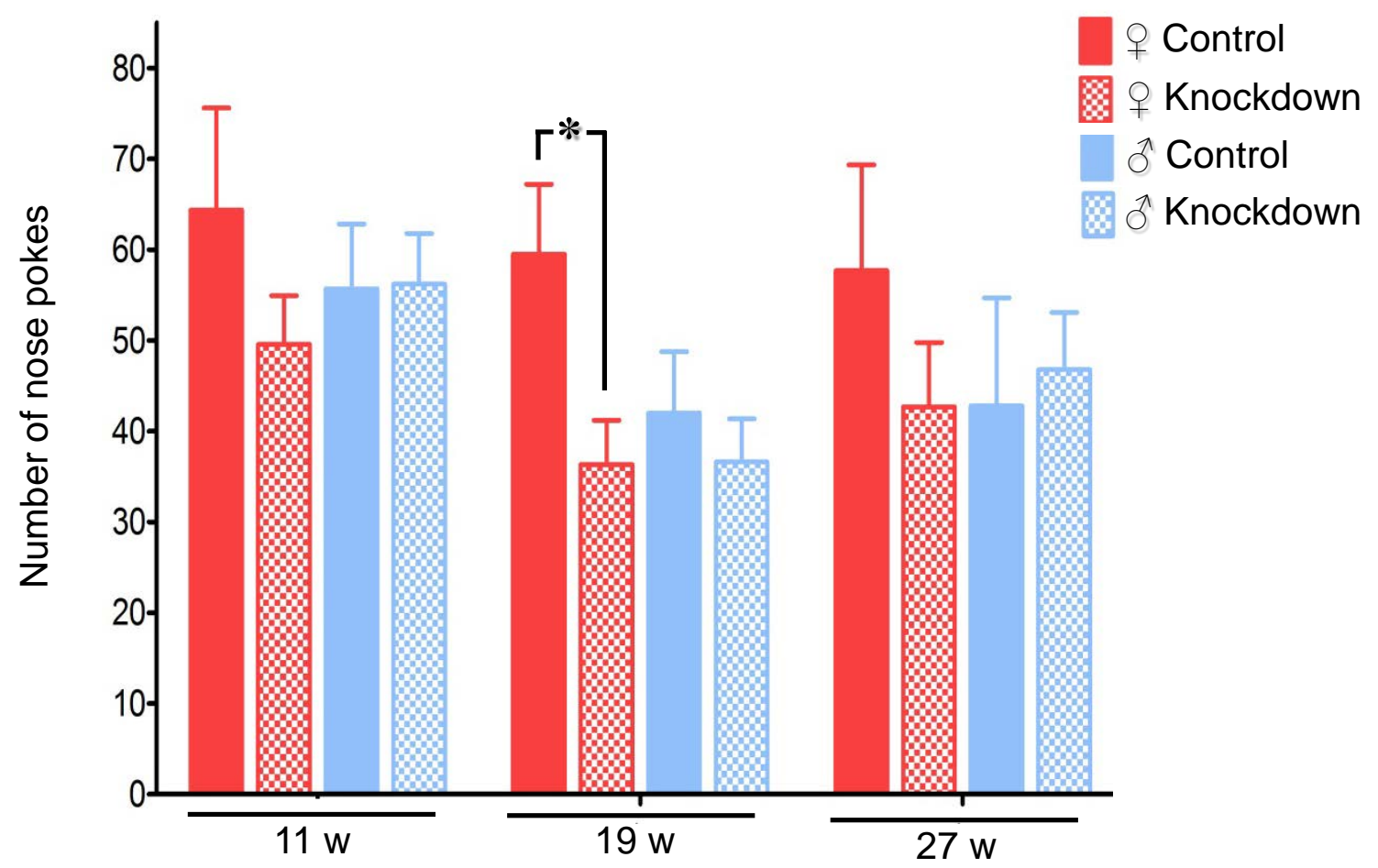

Figure 29. Female CamKIla-Cre/shGCL floxed 3 mice show fearlanxiety, according to the Hole-board test. The Hole-board test was measured in mice at 11, 19 and 27 weeks of age from CamKIla-Cre(+/-)/shGCL(-/-) (control) and CamKIl $\alpha-$ Cre $(+/-) /$ shGCL(+/-) (knockdown) female and male mice ( $n \geq 6$ each). Please, note the decrease in nose pokes in knockdown females, indicating an increase in anxiety/fear. ${ }^{*} \mathrm{p} \leq 0.05$ (Student's $t$ test). 

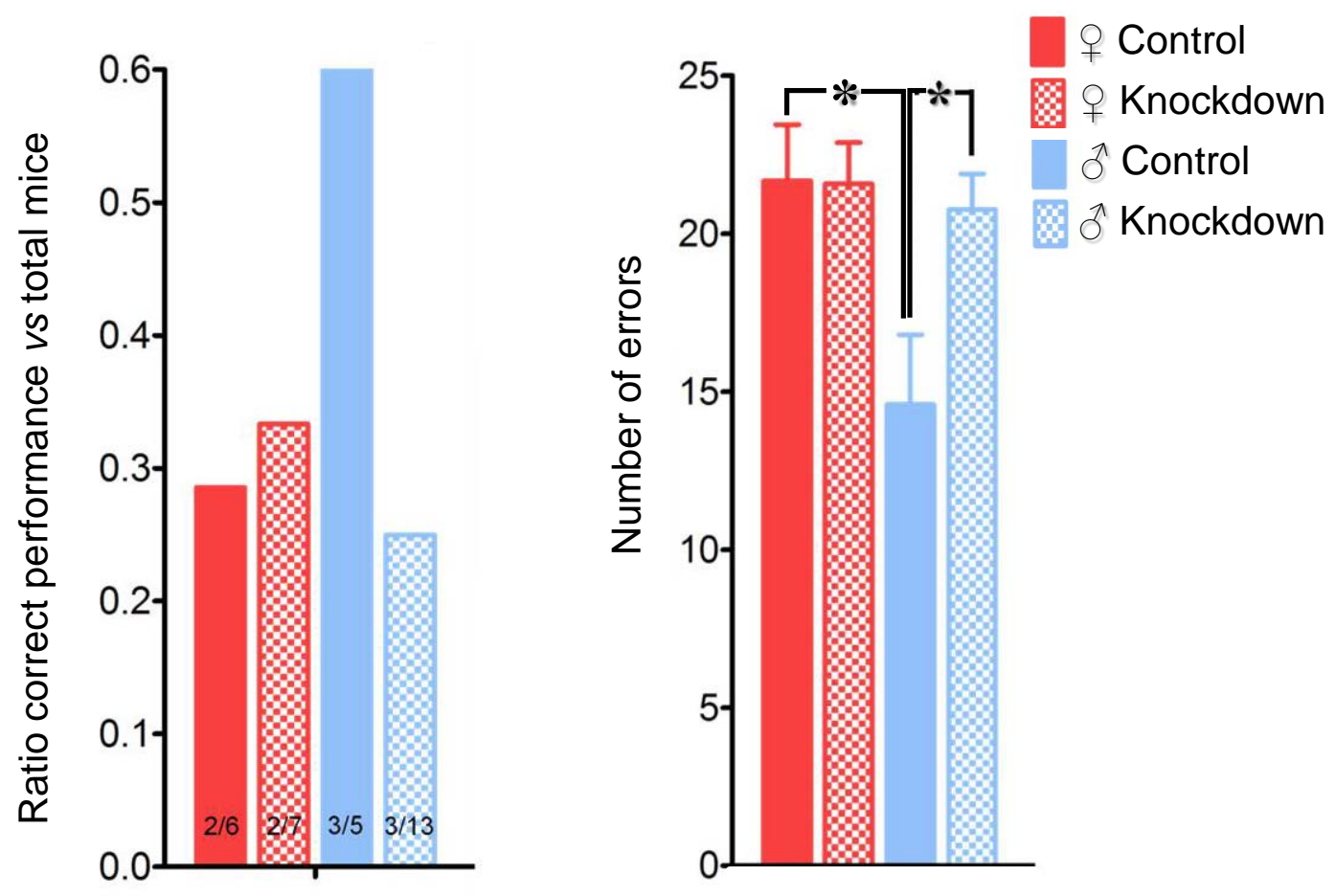

Figure 30. Male CamKIl $\alpha$-Cre/shGCL ${ }^{\text {floxed }}$-3 mice show loss of spatial memory, according to the Radial Arm Maze. The test was measured in mice at 15 weeks of age from CamKIl $\alpha-\mathrm{Cre}(+/-) / \mathrm{shGCL}(-/-)$ (control) and CamKIll $\alpha-\mathrm{Cre}(+/-$ )/shGCL(+/-) (knockdown) female and male mice ( $n \geq 6$ each). Left panel shows correct performances/total animals ratio, whereas the right panel shows the number of errors committed. Please, note that control male performed better than control female mice (increased correct performances/total animals ratio), suggesting better spatial memory in males; however, that ability of male mice was impaired in the knockdown group. * $\mathrm{p} \leq 0.05$ (Student's $t$ test). 


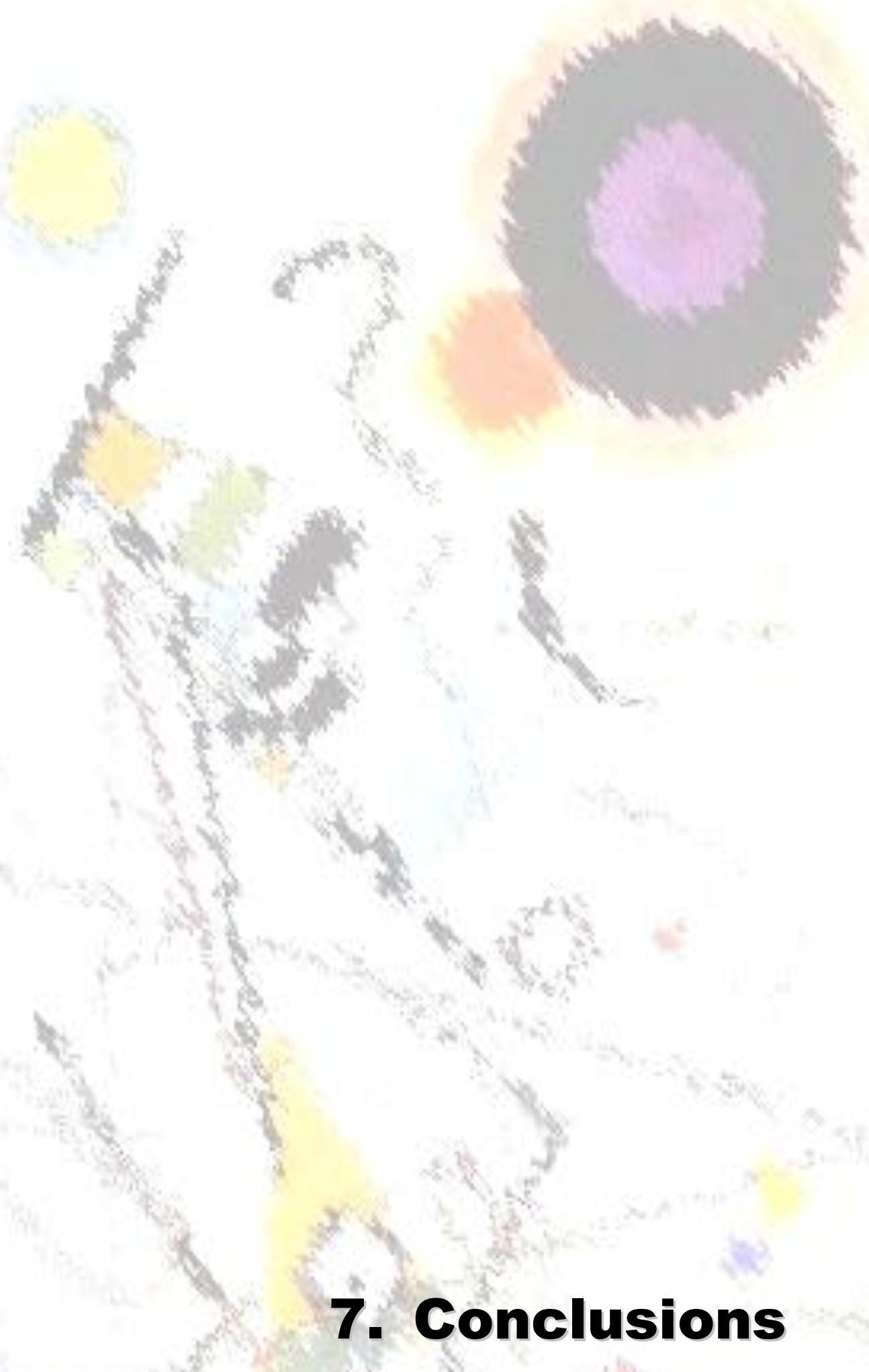

"Porque un día llegarán, (...) no para pintar la bahía, el mar, las barcas y los malecones, sino el calor del sol y el color del viento." ("Because one day they will arrive, (...) not to paint the bay, the sea, the boats and piers, but the heat of the sun and the color of the wind.

Rosamunde Pilcher. Los buscadores de conchas. Fragmento. (Rosamunde Pilcher. The Shell seekers. Fragment (Free translation)) 
At the light of the results presented in this Doctoral Thesis, we have obtained the following conclusions:

1. We have developed a new Cre-Lox based genetic tool designed to interfere, after recombination, with the synthesis of any protein in mouse in vivo, in a tissue- and time-controlled manner. For this purpose, two constructs were generated to cause protein knockdown in mouse by either microinjection in oocytes, or homologous recombination in embryonic stem (ES) cells. These tools can be suitable for the generation of new knockdown experimental models in the future.

2. We have generated a new Cre-Lox based mouse transgenic line $\left(s h G C L^{\text {floxed }}\right)$ that can be used to trigger knockdown interference on glutamate-cysteine ligase (GCL), the rate-limiting enzyme of the biosynthesis of glutathione, tissue-specifically and timecontrolled. Therefore, this shGCL $L^{\text {floxed }}$ mouse line is suitable for the investigation of tissue-specific oxidative stress in vivo.

3. By mating shGCL floxed mouse line with mice expressing Cre recombinase governed under the control of the neuron-specific $\mathrm{Ca}^{2+}$-calmodulin protein kinase-II $\alpha$ (CamKII $\alpha$ ) promoter (CamKII $\alpha$-Cre), we have obtained a progeny showing signs of oxidative stress in the CamKII $\alpha$-positive post-natal neurons, of the central nervous system, particularly in the striatum and the hippocampus. These results provide the proof-of-principle that our shGCL $L^{\text {floxed }}$ system is functional, and therefore can trigger oxidative stress in a tissue- and time-controlled manner.

4. By studying the behavioral signs in adult mice obtained by mating $s h G C L^{\text {floxed }}$ with CamKII $\alpha$-Cre, we observed that only the mice showing oxidative stress signs in the CamKII $\alpha$-positive post-natal neurons had an impaired motor coordination and cognitive functions, in a sex dependent manner. These results indicate that the induction of glutathione deficiency-triggered oxidative stress in the neurons of the striatum and the hippocampus in vivo is able to alter the correct brain function, resembling mental illness -such as anxiety-, dementia and Parkinson’s disease. 


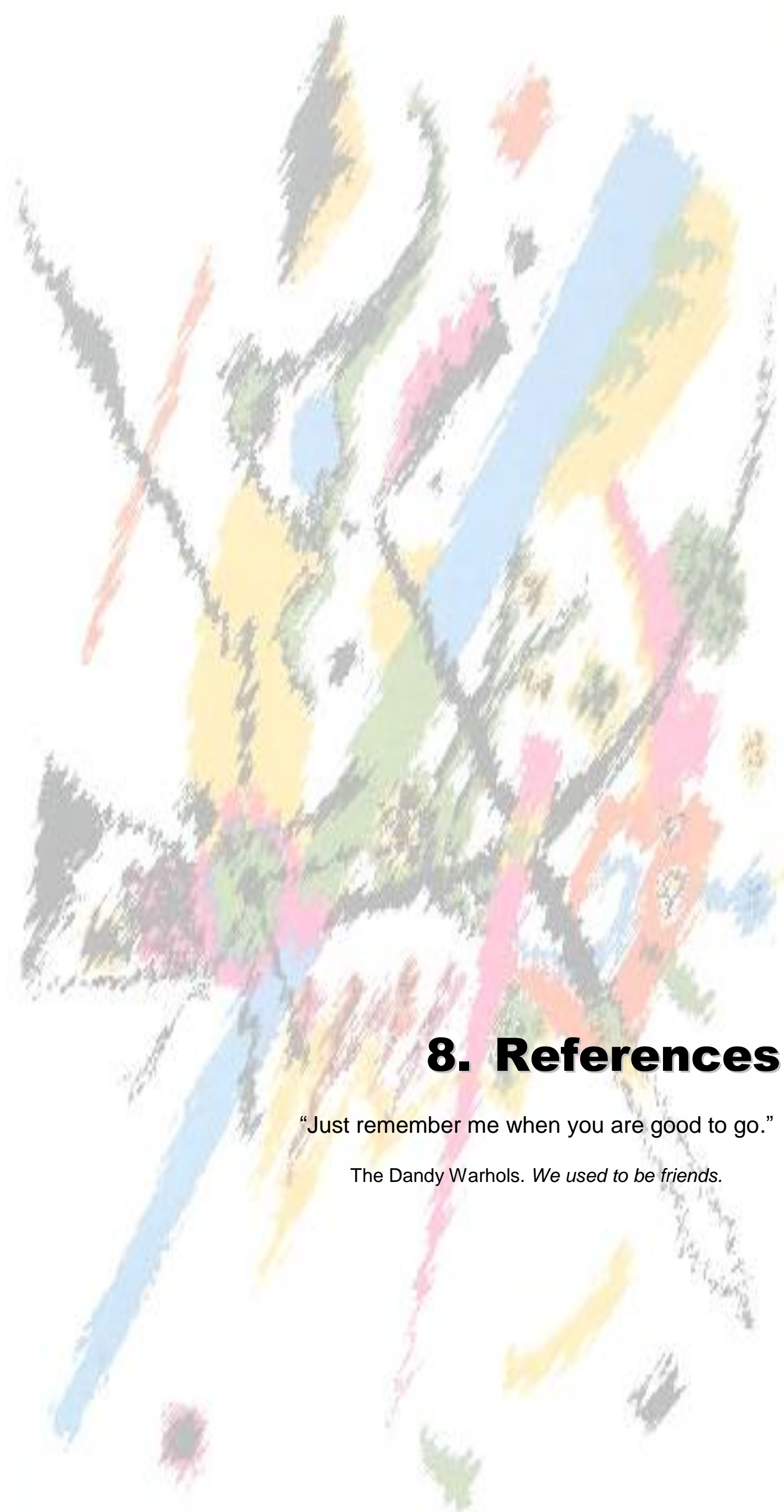


Andersen JK. Oxidative stress in neurodegeneration: cause or consequence? Nat Med 10 Suppl, S18-25 (2004).

Anderson ME \& Meister A. Transport and direct utilization of gammaglutamylcyst(e)ine for glutathione synthesis. Proc Natl Acad Sci U S A 80, 707-711 (1983).

Barja G. Free radicals and aging. Trends Neurosci 27, 595-600 (2004).

Benassi B, Fanciulli M, Fiorentino F, Porrello A, Chiorino G, Loda M, Zupi G \& Biroccio A. c-Myc phosphorylation is required for cellular response to oxidative stress. Mol Cell 21, 509-519 (2006).

Bolanos JP \& Heales SJ. Persistent mitochondrial damage by nitric oxide and its derivatives: neuropathological implications. Front Neuroenergetics 2, 1 (2010).

Bolaños JP, Heales SJR, Land JM \& Clark JB. Effect of peroxynitrite on the mitochondrial respiratory chain: differential susceptibility of neurones and astrocytes in primary cultures. J. Neurochem. 64, 1965-1972 (1995).

Bolaños JP, Moro MA, Lizasoain I \& Almeida A. Mitochondria and reactive oxygen and nitrogen species in neurological disorders and stroke: Therapeutic implications. Adv Drug Deliv Rev 61, 1299-1315 (2009).

Boveris A. Determination of the production of superoxide radicals and hydrogen peroxide in mitochondria. Methods Enzymol 105, 429-435 (1984).

Brand MD. The sites and topology of mitochondrial superoxide production. Exp Gerontol 45, 466-472 (2010).

Circu ML \& Aw TY. Reactive oxygen species, cellular redox systems, and apoptosis. Free Radic Biol Med 48, 749-762 (2010).

Cotgreave IA \& Gerdes RG. Recent trends in glutathione biochemistry--glutathioneprotein interactions: a molecular link between oxidative stress and cell proliferation? Biochem Biophys Res Commun 242, 1-9 (1998).

Curtis JM, Hahn WS, Long EK, Burrill JS, Arriaga EA \& Bernlohr DA. Protein carbonylation and metabolic control systems. Trends Endocrinol Metab 23, 399-406 (2012).

Chen Y, Shertzer HG, Schneider SN, Nebert DW \& Dalton TP. Glutamate cysteine ligase catalysis: dependence on ATP and modifier subunit for regulation of tissue glutathione levels. J Biol Chem 280, 33766-33774 (2005).

Chinta SJ \& Andersen JK. Redox imbalance in Parkinson's disease. Biochim Biophys Acta 1780, 1362-1367 (2008). 
D'Autreaux B \& Toledano MB. ROS as signalling molecules: mechanisms that generate specificity in ROS homeostasis. Nat Rev Mol Cell Biol 8, 813-824 (2007).

Dalton TP, Chen Y, Schneider SN, Nebert DW \& Shertzer HG. Genetically altered mice to evaluate glutathione homeostasis in health and disease. Free Radic Biol Med 37, 1511-1526 (2004).

Dalton TP, Dieter MZ, Yang Y, Shertzer HG \& Nebert DW. Knockout of the mouse glutamate cysteine ligase catalytic subunit (Gclc) gene: embryonic lethal when homozygous, and proposed model for moderate glutathione deficiency when heterozygous. Biochem Biophys Res Commun 279, 324-329 (2000).

Dalle-Donne I, Rossi R, Giustarini D, Colombo R \& Milzani A. S-glutathionylation in protein redox regulation. Free Radic Biol Med 43, 883-898 (2007).

Diaz-Hernandez JI, Almeida A, Delgado-Esteban M, Fernandez E \& Bolanos JP. Knockdown of glutamate-cysteine ligase by small hairpin RNA reveals that both catalytic and modulatory subunits are essential for the survival of primary neurons. $J$ Biol Chem. 280, 38992-39001 (2005).

Douglas KT. Mechanism of action of glutathione-dependent enzymes. Adv Enzymol Relat Areas Mol Biol 59, 103-167 (1987).

Dringen R. Metabolism and functions of glutathione in brain. Progr. Neurobiol. 62, 649-671 (2000).

Dringen R, Gutterer JM, Gros C \& Hirrlinger J. Aminopeptidase N mediates the utilization of the GSH precursor CysGly by cultured neurons. J Neurosci Res 66, 10031008 (2001).

Dringen R \& Hirrlinger J. Glutathione pathways in the brain. Biol Chem 384, 505-516 (2003).

Dringen R, Kussmaul L, Gutterer JM, Hirrlinger J \& Hamprecht B. The glutathione system of peroxide detoxification is less efficient in neurons than in astrocytes. J. Neurochem. 72, 2523-2530 (1999a).

Dringen R, Pfeiffer B \& Hamprecht B. Synthesis of the antioxidant glutathione in neurons: supply by astrocytes of CysGly as precursor for neuronal glutathione. $J$. Neurosci. 19, 562-569 (1999b).

Fernandez-Fernandez S, Almeida A \& Bolanos JP. Antioxidant and bioenergetic coupling between neurons and astrocytes. Biochem J 443, 3-11 (2012).

Flohe L. The labour pains of biochemical selenology: the history of selenoprotein biosynthesis. Biochim Biophys Acta 1790, 1389-1403 (2009).

Flohe L, Gunzler W, Jung G, Schaich E \& Schneider F. [Glutathione peroxidase. II. Substrate specificity and inhibitory effects of substrate analogues]. Hoppe Seylers $Z$ Physiol Chem 352, 159-169 (1971). 
Franco R \& Cidlowski JA. Apoptosis and glutathione: beyond an antioxidant. Cell Death Differ 16, 1303-1314 (2009).

Franklin CC, Krejsa CM, Pierce RH, White CC, Fausto N \& Kavanagh TJ. Caspase-3-Dependent Cleavage of the Glutamate-L-Cysteine Ligase Catalytic Subunit during Apoptotic Cell Death. Am J Pathol 160, 1887-1894 (2002).

Fukui H \& Moraes CT. The mitochondrial impairment, oxidative stress and neurodegeneration connection: reality or just an attractive hypothesis? Trends Neurosci 31, 251-256 (2008).

Garcia-Ruiz C \& Fernandez-Checa JC. Redox regulation of hepatocyte apoptosis. $J$ Gastroenterol Hepatol 22 Suppl 1, S38-42 (2007).

Gegg ME, Beltran B, Salas-Pino S, Bolaños JP, Clark JB, Moncada S \& Heales SJR. Differential effect of nitric oxide on glutathione metabolism and mitochondrial function in astrocytes and neurones: implications for neuroprotection /neurodegeneration? J. Neurochem. 86, 228-237 (2003).

Griffith OW. Biologic and pharmacologic regulation of mammalian glutathione synthesis. Free Radic Biol Med 27, 922-935 (1999).

Halliwell B. Free radicals and antioxidants - quo vadis? Trends Pharmacol Sci 32, 125130 (2011).

Harrison FE \& May JM. Vitamin C function in the brain: vital role of the ascorbate transporter SVCT2. Free Radic Biol Med 46, 719-730 (2009).

Hayes JD, Flanagan JU \& Jowsey IR. Glutathione transferases. Annu Rev Pharmacol Toxicol 45, 51-88 (2005).

Heales SJR, Bolaños JP, Stewart VC, Brookes PS, Land JM \& Clark JB. Nitric oxide, mitochondrial and neurological disease. Biochim. Biophys. Acta 1410, 215-228 (1999).

Hekimi S, Lapointe J \& Wen Y. Taking a "good" look at free radicals in the aging process. Trends Cell Biol 21, 569-576 (2011).

Hirrlinger J, Konig J, Keppler D, Lindenau J, Schulz JB \& Dringen R. The multidrug resistance protein MRP1 mediates the release of glutathione disulfide from rat astrocytes during oxidative stress. J Neurochem 76, 627-636 (2001).

Hogg N. The biochemistry and physiology of S-nitrosothiols. Annu Rev Pharmacol Toxicol 42, 585-600 (2002).

Huang CS, Anderson ME \& Meister A. Amino acid sequence and function of the light subunit of rat kidney $\gamma$-glutamylcysteine synthetase. J. Biol. Chem. 268, 2057820583 (1993a). 
Huang CS, Chang LS, Anderson ME \& Meister A. Catalytic and regulatory properties of the heavy subunit of rat kidney gamma-glutamylcysteine synthetase. $J$. Biol. Chem. 268, 19675-19680 (1993b).

Huang CS, He W, Meister A \& Anderson ME. Amino acid sequence of rat kidney glutathione synthetase. Proc Natl Acad Sci U S A 92, 1232-1236 (1995).

Jenner P, Dexter DT, Sian J, Schapira AHV \& Marsden CD. Oxidative stress as a cause of nigral cell death in Parkinson's disease and incidental Lewy body disease. Ann. Neurol. 32, S82-S87 (1992).

Jones DP, Mody VC, Jr., Carlson JL, Lynn MJ \& Sternberg P, Jr. Redox analysis of human plasma allows separation of pro-oxidant events of aging from decline in antioxidant defenses. Free Radic Biol Med 33, 1290-1300 (2002).

Kang Y, Wang Y, Zhu L \& Men X. [Purification and analysis of polysaccharides from the caudex of Undaria pinnatifida]. Zhong Yao Cai 28, 769-771 (2005).

Kelner MJ \& Montoya MA. Structural organization of the human glutathione reductase gene: determination of correct cDNA sequence and identification of a mitochondrial leader sequence. Biochem Biophys Res Commun 269, 366-368 (2000).

Le Moan N, Clement G, Le Maout S, Tacnet F \& Toledano MB. The Saccharomyces cerevisiae proteome of oxidized protein thiols: contrasted functions for the thioredoxin and glutathione pathways. J Biol Chem 281, 10420-10430 (2006).

Lee AG. Hydroxychloroquine screening. Br J Ophthalmol 89, 521-522 (2005).

Levy OA, Malagelada C \& Greene LA. Cell death pathways in Parkinson's disease: proximal triggers, distal effectors, and final steps. Apoptosis 14, 478-500 (2009).

Lieberman MW, Wiseman AL, Shi ZZ, Carter BZ, Barrios R, Ou CN, ChevezBarrios P, Wang Y, Habib GM, Goodman JC, Huang SL, Lebovitz RM \& Matzuk MM. Growth retardation and cysteine deficiency in gamma-glutamyl transpeptidasedeficient mice. Proc Natl Acad Sci U S A 93, 7923-7926 (1996).

Liu H, Wang H, Shenvi S, Hagen TM \& Liu RM. Glutathione metabolism during aging and in Alzheimer disease. Ann N Y Acad Sci 1019, 346-349 (2004).

Lu SC. Regulation of glutathione synthesis. Curr Top Cell Regul 36, 95-116 (2000).

Lu SC. Regulation of glutathione synthesis. Mol Aspects Med 30, $42-59$ (2009).

Maiorino M, Ursini F, Bosello V, Toppo S, Tosatto SC, Mauri P, Becker K, Roveri A, Bulato C, Benazzi L, De Palma A \& Flohe L. The thioredoxin specificity of Drosophila GPx: a paradigm for a peroxiredoxin-like mechanism of many glutathione peroxidases. J Mol Biol 365, 1033-1046 (2007).

Makar TK, Nedergaard M, Preuss A, Gelbard AS, Perumal AS \& Cooper AJL. Vitamin E, ascorbate, glutathione, glutathione disulfide, and enzymes of glutathione 
metabolism in cultures of chick astrocytes and neurones: evidence that astrocytes play an important role in antioxidative processes in the brain. J. Neurochem. 62, 45-53 (1994).

Mari M, Morales A, Colell A, Garcia-Ruiz C \& Fernandez-Checa JC. Mitochondrial glutathione, a key survival antioxidant. Antioxid Redox Signal 11, 26852700 (2009).

Meister A. Glutathione metabolism and its selective modification. J. Biol. Chem. 263, 17205-17208 (1988).

Meister A \& Anderson ME. Glutathione. Annu Rev Biochem 52, 711-760 (1983).

Meredith MJ \& Reed DJ. Status of the mitochondrial pool of glutathione in the isolated hepatocyte. J Biol Chem 257, 3747-3753 (1982).

Minelli A, Bellezza I, Conte C \& Culig Z. Oxidative stress-related aging: A role for prostate cancer? Biochim Biophys Acta 1795, 83-91 (2009).

Murphy MP. How mitochondria produce reactive oxygen species. Biochem J 417, 1-13 (2009).

Njalsson R. Glutathione synthetase deficiency. Cell Mol Life Sci 62, 1938-1945 (2005).

Oja SS, Janaky R, Varga V \& Saransaari P. Modulation of glutamate receptor functions by glutathione. Neurochem Int 37, 299-306 (2000).

Orlowski M \& Meister A. Isolation of highly purified g-glutamylcysteine synthetase from rat kidney. Biochemistry 10, 372-380 (1971).

Paolicchi A, Dominici S, Pieri L, Maellaro E \& Pompella A. Glutathione catabolism as a signaling mechanism. Biochem Pharmacol 64, 1027-1035 (2002).

Paolicchi A, Sotiropuolou M, Perego P, Daubeuf S, Visvikis A, Lorenzini E, Franzini M, Romiti N, Chieli E, Leone R, Apostoli P, Colangelo D, Zunino F \& Pompella A. gamma-Glutamyl transpeptidase catalyses the extracellular detoxification of cisplatin in a human cell line derived from the proximal convoluted tubule of the kidney. Eur J Cancer 39, 996-1003 (2003).

Papadopoulos MC, Koumenis IL, Dugan LL \& Giffard RG. Vulnerability to glucose deprivation injury correlates with glutathione levels in astrocytes. Brain Res 748, 151-156 (1997).

Perry TL, Godin DV \& Hansen S. Parkinson's disease: a disorder due to nigral glutathione deficiency? Neurosci Lett. 33, 305-310 (1982).

Polekhina G, Board PG, Gali RR, Rossjohn J \& Parker MW. Molecular basis of glutathione synthetase deficiency and a rare gene permutation event. EMBO J 18, 32043213 (1999). 
Pompella A, Corti A, Paolicchi A, Giommarelli C \& Zunino F. Gammaglutamyltransferase, redox regulation and cancer drug resistance. Curr Opin Pharmacol 7, 360-366 (2007).

Poyton RO, Ball KA \& Castello PR. Mitochondrial generation of free radicals and hypoxic signaling. Trends Endocrinol Metab 20, 332-340 (2009).

Rahman I. Regulation of glutathione in inflammation and chronic lung diseases. Mutat Res 579, 58-80 (2005).

Rahman Q, Abidi P, Afaq F, Schiffmann D, Mossman BT, Kamp DW \& Athar M. Glutathione redox system in oxidative lung injury. Crit Rev Toxicol 29, 543-568 (1999).

Rebrin I \& Sohal RS. Pro-oxidant shift in glutathione redox state during aging. Adv Drug Deliv Rev 60, 1545-1552 (2008).

Ristoff E \& Larsson A. Patients with genetic defects in the gamma-glutamyl cycle. Chem Biol Interact 111-112, 113-121 (1998).

Ross D, Cotgreave I \& Moldeus P. The interaction of reduced glutathione with active oxygen species generated by xanthine-oxidase-catalyzed metabolism of xanthine. Biochim Biophys Acta 841, 278-282 (1985).

Sagara J, Miura K \& Bannai S. Cystine uptake and glutathione level in fetal brain cells in primary culture and in suspension. J Neurochem 61, 1667-1671 (1993).

Schafer FQ \& Buettner GR. Redox environment of the cell as viewed through the redox state of the glutathione disulfide/glutathione couple. Free Radic Biol Med 30, 1191-1212 (2001).

Scheiber IF \& Dringen R. Copper-treatment increases the cellular GSH content and accelerates GSH export from cultured rat astrocytes. Neurosci Lett 498, 42-46 (2011).

Shi ZZ, Habib GM, Rhead WJ, Gahl WA, He X, Sazer S \& Lieberman MW. Mutations in the glutathione synthetase gene cause 5-oxoprolinuria. Nat Genet 14, 361365 (1996).

Shi ZZ, Osei-Frimpong J, Kala G, Kala SV, Barrios RJ, Habib GM, Lukin DJ, Danney CM, Matzuk MM \& Lieberman MW. Glutathione synthesis is essential for mouse development but not for cell growth in culture. Proc Natl Acad Sci U S A 97, 5101-5106 (2000).

Soltaninassab SR, Sekhar KR, Meredit MJ \& Freeman ML. Multi-faceted regulation of gamma-glutamylcysteine synthetase. J Cell Physiol 182, 163-170 (2000).

Stull FW \& Martin DF. Comparative ease of separation of mixtures of selected nuisance anions (nitrate, nitrite, sulfate, phosphate) using Octolig. J Environ Sci Health A Tox Hazard Subst Environ Eng 44, 1545-1550 (2009). 
Sugimoto M, Kuhlenkamp J, Ookhtens M, Aw TY, Reeve J, Jr. \& Kaplowitz N. Gamma-glutamylcysteine: a substrate for glutathione S-transferases. Biochem Pharmacol 34, 3643-3647 (1985).

Suzuki M \& Kurata M. Effects of ATP level on glutathione regeneration in rabbit and guinea-pig erythrocytes. Comp Biochem Physiol B 103, 859-862 (1992).

Takebe G, Yarimizu J, Saito Y, Hayashi T, Nakamura H, Yodoi J, Nagasawa S \& Takahashi K. A comparative study on the hydroperoxide and thiol specificity of the glutathione peroxidase family and selenoprotein P. J Biol Chem 277, 41254-41258 (2002).

Temple MD, Perrone GG \& Dawes IW. Complex cellular responses to reactive oxygen species. Trends Cell Biol 15, 319-326 (2005).

Toppo S, Flohe L, Ursini F, Vanin S \& Maiorino M. Catalytic mechanisms and specificities of glutathione peroxidases: variations of a basic scheme. Biochim Biophys Acta 1790, 1486-1500 (2009).

Veas-Perez de Tudela M, Delgado-Esteban M, Cuende J, Bolanos JP \& Almeida A. Human neuroblastoma cells with MYCN amplification are selectively resistant to oxidative stress by transcriptionally up-regulating glutamate cysteine ligase. $J$ Neurochem 113, 819-825 (2010).

Wefers $\mathbf{H}$ \& Sies H. Oxidation of glutathione by the superoxide radical to the disulfide and the sulfonate yielding singlet oxygen. Eur J Biochem 137, 29-36 (1983).

Wells WW, Xu DP, Yang YF \& Rocque PA. Mammalian thioltransferase (glutaredoxin) and protein disulfide isomerase have dehydroascorbate reductase activity. J Biol Chem 265, 15361-15364 (1990).

Wild AC, Moinova HR \& Mulcahy RT. Regulation of gamma-glutamylcysteine synthetase subunit gene expression by the transcription factor Nrf2. J Biol Chem 274, 33627-33636 (1999).

Will Y, Fischer KA, Horton RA, Kaetzel RS, Brown MK, Hedstrom O, Lieberman MW \& Reed DJ. gamma-glutamyltranspeptidase-deficient knockout mice as a model to study the relationship between glutathione status, mitochondrial function, and cellular function. Hepatology 32, 740-749 (2000).

Winterbourn CC \& Metodiewa D. The reaction of superoxide with reduced glutathione. Arch Biochem Biophys 314, 284-290 (1994).

Wu G, Fang YZ, Yang S, Lupton JR \& Turner ND. Glutathione metabolism and its implications for health. J Nutr 134, 489-492 (2004a).

Wu T, Wang HL, Chu CC, Yu JM, Chen JY \& Huang CC. Clinical and electrophysiological studies of a family with probable X-linked dominant CharcotMarie-Tooth neuropathy and ptosis. Chang Gung Med J 27, 489-500 (2004b). 
Yang H, Zeng Y, Lee TD, Yang Y, Ou X, Chen L, Haque M, Rippe R \& Lu SC. Role of AP-1 in the coordinate induction of rat glutamate-cysteine ligase and glutathione synthetase by tert-butylhydroquinone. J Biol Chem 277, 35232-35239 (2002a).

Yang Y, Dieter MZ, Chen Y, Shertzer HG, Nebert DW \& Dalton TP. Initial characterization of the glutamate-cysteine ligase modifier subunit Gclm(-/-) knockout mouse. Novel model system for a severely compromised oxidative stress response. $J$ Biol Chem 277, 49446-49452 (2002b).

Yant LJ, Ran Q, Rao L, Van Remmen H, Shibatani T, Belter JG, Motta L, Richardson A \& Prolla TA. The selenoprotein GPX4 is essential for mouse development and protects from radiation and oxidative damage insults. Free Radic Biol Med 34, 496-502 (2003).

Zeevalk GD, Razmpour R \& Bernard LP. Glutathione and Parkinson's disease: is this the elephant in the room? Biomed Pharmacother 62, 236-249 (2008).

Zhao YX, Yin HQ, Yu QT, Qiao Y, Dai HY, Zhang MX, Zhang L, Liu YF, Wang LC, Liu de S, Deng BP, Zhang YH, Pan CM, Song HD, Qu X, Jiang H, Liu CX, Lu XT, Liu B, Gao F \& Dong B. ACE2 overexpression ameliorates left ventricular remodeling and dysfunction in a rat model of myocardial infarction. Hum Gene Ther 21, 1545-1554 (2010). 


\section{Resumen en español}




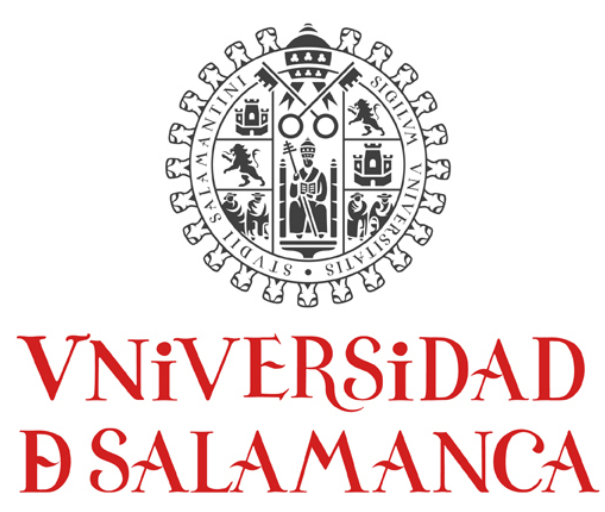

CAMPUS DE EXCELENCIA INTERNACIONAL

\title{
Desarrollo de un modelo experimental de estrés oxidativo in vivo
}

\author{
TESIS DOCTORAL \\ (RESUMEN)
}

\section{SEILA FERNÁNDEZ FERNÁNDEZ}

Salamanca, 2013

\author{
Dirigida por Prof. Juan P. Bolaños ${ }^{1}$ and Dr. Ángeles Almeida ${ }^{1,2}$ \\ ${ }^{1}$ Departamento de Bioquímica y Biología Molecular-Universidad de Salamanca \\ ${ }^{2}$ Instituto of Investigación Biomédica de Salamanca- Universidad, Hospital de \\ Salamanca \\ Instituto de Biología Funcional y Genómica (IBFG), \\ Universidad de Salamanca-CSIC \\ Zacarías González, 2 \\ 37007 Salamanca (España)
}




\section{Introducción}

Los efectos deletéreos de las especies reactivas de oxígeno (ROS), ocurren durante la edad adulta, y se ha sugerido que un exceso de ROS -estrés oxidativo- puede ser un factor relevante en los procesos neurodegenerativos (Curtis et al., 2012). El glutatión (GSH) es uno de los antioxidantes más abundantes y en enfermedades neurodegenerativas -como el Parkinson- o en desórdenes mentales, la falta de GSH es el primer indicador bioquímico conocido de degeneración neuronal (Jenner et al., 1992; Liu et al., 2004; Perry et al., 1982). Esta observación ha conducido a sugerir que el estrés oxidativo puede estar detrás de las causas de mal funcionamiento neuronal asociadas a estos desórdenes neurológicos (Andersen, 2004; Chinta and Andersen, 2008). Desafortunadamente, debido a la falta de una herramienta lo suficientemente robusta, el efecto específico de una deficiencia del GSH en la patogénesis de las enfermedades neurológicas no ha sido mostrado nunca in vivo (Barja, 2004), y por lo tanto el papel real del estrés oxidativo mediado por déficit de GSH en estos desórdenes continua sin ser aclarado.

El glutatión es un tripéptido ( $\gamma$-glutamilcisteinilglicina) sintetizado en dos reacciones sucesivas dependientes de ATP. La glutamato-cisteína ligasa (GCL o $\gamma$-glutamilcisteína sintetasa; EC 6.3.2.2) cataliza la primera -y limitante- reacción, formando $\gamma$ glutamilcisteína a partir de glutamato y cisteína (Esquema 1) ) (Orlowski and Meister, 1971). A continuación sigue la reacción de la glutatión sintetasa (EC 6.3.2.3), que añade glicina a la $\gamma$-glutamilcisteína, formando glutatión (Esquema 1) (Huang et al., 1995). La GCL es una enzima heterodimérica compuesta por una subunidad catalítica (pesada; 73kDa) (Huang et al., 1993) y otra moduladora (ligera; 27,7 kDa) (Makar et al., 1994). En estudios realizados con GCL purificada se ha demostrado que los sitios activos se localizan en la subunidad catalítica, mientras que la subunidad moduladora incrementa la afinidad de la subunidad catalítica por el glutamato y disminuye la sensibilidad a la inhibición por retroalimentación mediada por GSH (Huang et al., 1993).

En el cerebro, donde no tenemos evidencia de que la enzima haya sido purificada, la actividad de la GCL es muy baja (Orlowski and Meister, 1971), aunque es más alta en los astrocitos si se les compara con las neuronas (Dringen et al., 1999a; Gegg et al., 
2003; Makar et al., 1994). Esto contribuye a la alta resistencia de los astrocitos al estrés oxidativo respecto a las neuronas (Bolaños et al., 1995; Dringen et al., 1999a).

Los astrocitos cooperan con las neuronas en la biosíntesis neuronal del antioxidante GSH (Dringen, 2000; Dringen et al., 1999b). De hecho, los astrocitos orquestan la mayor respuesta antioxidante a través de la activación de Nrf2, que regula la biosíntesis de GSH, además de otros factores (Esquema 1) (Fernandez-Fernandez et al., 2012). Así, los astrocitos proporcionan precursores del GSH a las neuronas (Bolanos and Heales, 2010; Dringen, 2000; Dringen et al., 1999b) a través de un complejo mecanismo que constituye una estrategia antioxidante clave. Nuestro grupo ha demostrado previamente que la modulación genética de la biosíntesis del GSH, mediante la inhibición o la sobreexpresión de la subunidad catalítica de la GCL, influye decisivamente en la vulnerabilidad de neuronas de cultivo primario contra un exceso de óxido nítrico y excitotoxidad (Diaz-Hernandez et al., 2005). Curiosamente, la presencia de astrocitos bordeando las neuronas en co-cultivo no fue suficiente para prevenir la muerte neuronal por apoptosis debida a la pérdida de GCL; esto confirma que las neuronas requieren una maquinaria biosintética intacta para generar GSH a partir de sus precursores. Así, limitando tanto el aporte de los precursores del GSH como la capacidad de las neuronas para utilizarlo, conduce a un estrés oxidativo en las neuronas que conlleva a neurodegeneración, al menos en cultivo. Esto nos ha llevado a hipotetizar que la inhibición neuronal -específica y temporalmente regulada- de la GCL in vivo puede generar disfunciones neurológicas espontáneas, mimetizando así los problemas neurológicos asociados con la enfermedad de Parkinson u otras enfermedades mentales.

Los modelos in vivo existentes para estudiar la deficiencia de la subunidad catalítica de la GCL en el cerebro son escasos y han fallado. Ratones homocigotos knockout para la subunidad catalítica de la GCL no son viables más allá del octavo día de desarrollo embrionario, y los heterocigotos muestran mecanismos de compensación como un incremento en la síntesis de ascorbato (Dalton et al., 2000; Shi et al., 2000). Además, este sistema genético no permite el bloqueo de la GCL específicamente en un tejido o sometido a un control temporal, no siendo posible investigar el papel del estrés oxidativo en el sistema nervioso central en la edad adulta. Como se indica arriba, nosotros habíamos identificado previamente un small hairpin RNA (shRNA) dirigido contra la subunidad catalítica de la GCL que, en neuronas en cultivo, generaba estrés 
oxidativo espontáneo (Diaz-Hernandez et al., 2005). Sin embargo, no se conoce si implementar esta estrategia de RNA de interferencia (RNAi) in vivo puede ser capaz de generar un ratón que exprese condicionalmente el shRNA de la GCL en neuronas del sistema nervioso central, particularmente en neuronas del hipocampo. Creemos que este modelo, si fuera satisfactorio, supondría el primer modelo tisular específico e inducible de estrés oxidativo disponible para, por ejemplo, entender los mecanismos moleculares subyacentes a las enfermedades neurológicas, tanto como para indagar posibles estrategias terapéuticas para tratar estos desórdenes. 


\section{Hipótesis y objetivos}

\section{Hipótesis}

Nuestro grupo de investigación identificó previamente un shRNA específico dirigido contra la subunidad catalítica de la GCL que, en neuronas en cultivo, generaba estrés oxidativo espontáneo (Diaz-Hernandez et al., 2005). Sin embargo, la posibilidad de implementar esta estrategia de RNAi in vivo para producir un ratón condicional doble expresando shRNA de la GCL en células del sistema nervioso central no está comprobada. Creemos que puede suponer un excelente modelo tisular e inducible para recrear el estrés oxidativo in vivo.

\section{Objetivos}

A la luz de los fundamentos previamente mencionados, los objetivos para la presente Tesis Doctoral fueron:

1. Diseñar y generar un ratón transgénico que porte un small hairpin RNA (shRNA) contra la subunidad catalítica de la glutamato-cisteín ligasa (GCL) (shGCL), rodeado por sitios de recombinación mediada por Cre.

2. Generar un ratón adulto que exprese shGCL en neuronas in vivo utilizando el sistema de la recombinasa Cre.

3. Caracterizar bioquímica, inmuno-histológica y comportamentalmente los ratones adultos que expresen shGCL en neuronas.

Con los resultados esperados, pretendemos generar ratones específicos tisularmente e inducibles temporalmente con una biosíntesis menor de glutatión, lo que podría ser potencialmente útil para la identificación de nuevas proteínas sensibles a procesos oxidativos y que estén involucradas en desórdenes neurológicos. 


\section{Resultados}

\section{Generación de la construcción $\operatorname{shGCL^{\text {floxed}}}$}

La construcción shGCL floxed (Esquema 2) se consiguió tras once fases de clonación y subclonación, utilizando elementos preexistentes de varios plásmidos comerciales y secuencias sintetizadas químicamente e introducidos como oligonucleótidos. Cada paso en la clonación generó un nuevo vector, siendo denominados de pPI a pPXI indicando en números romanos el paso de clonación.

El plásmido pPI fue obtenido de un plásmido pIRES2-eGFP (5,3 kb) modificado para contener la secuencia Lox2272 en orientación sentido en el extremo 3' del promotor CMV. La digestión con las enzimas de restricción (ER) NheI y XmaI permitieron linearizar el plásmido (Figura 1.a) para contener extremos compatibles en el sito Lox2272 en orientación sentido. El sitio de restricción para NheI desapareció intencionalmente debido a la secuencia Lox2272 diseñada, lo que permitió seleccionar los clones debido al pequeño fragmento insertado (Figura 1.b). El plásmido resultante fue de $5,3 \mathrm{~kb}$.

El plásmido pPII fue generado a partir del plásmido comercial pSuper.neo-gfp (5,4 kb), el cual fue modificado para contener la secuencia LoxP en orientación sentido (final) en orientación anti-sentido al extremo 3' del promotor H1. La linearización del vector (Figura 1.c) usando las ER BglII y XhoI permitió la consecuente ligación del sitios LoxP en orientación sentido, debido a sus extremos diseñados para ser compatibles y que como resultado determinó la pérdida intencional de esos sitios de restricción útiles para la identificación de los clones. (Figura 1.d). También se introdujo el sitio de restricción SalI y un segundo sitio XmaI utilizado en los siguientes pasos de clonación. El plásmido pPII resultante tuvo un tamaño de 5.447 pb.

El plásmido pPIII fue generado a partir del pPII que fue modificado para contener al Adaptador1 en el extremo 5' del promotor H1. El pPII fue linearizado (Figura 2.a) con las ER EcoRI y NotI, escindiendo un fragmento de $~ 2.200$ pb y el esqueleto del vector, de $\sim 3.000 \mathrm{pb}$, que fue purificado para la subsiguiente ligación con el Adaptador1. Los extremos compatibles diseñados para la ligación con el Adaptador 1 generaron la pérdida intencional del sitio de EcoRI (Figura 2.b) y la introducción de un sitio MluI, 
útil para las siguientes clonaciones. El plásmido pPIII resultante tuvo un tamaño de $3.183 \mathrm{pb}$.

El plásmido pPIV fue generado a partir del plásmido pPIII que fue modificado para contener el gen de resistencia a la neomicina en orientación anti-sentido al extremo 3' del sitio LoxP en orientación sentido. pPIII fue linearizado (Figura 2.d) con las enzimas de restricción SalI y XmaI. El gen de resistencia a la neomicina fue escindido del vector comercial pcDNA3.1(+) (5,4 kb) realizando una doble digestión (Figura 2.c) con las ER SalI y XmaI. Tanto el plásmido pPIII linearizado como el gen de resistencia a la neomicina fueron ligados juntos para obtener el pPIV, con un tamaño de 4.349 pb.

El plásmido pPV fue generado a partir del plásmido comercial peGFP-C1 (4.7 Kb), cuyo sitio múltiple de clonación (multiple cloning site, MCS) fue escindido usando las ER BglII y BamHI (Figura 3.a), tras lo cual se religó, dando como resultado la pérdida de ambos sitios de restricción (Figura 3.b). El plásmido pPV resultante tuvo un tamaño de $4,6 \mathrm{~kb}$.

El plásmido pPVI fue generado utilizando el plásmido pPV que fue modificado para contener la secuencia Lox2272 anti-sentido en orientación sentido al extremo 5' de la secuencia que codifica la eGFP. La linearización de pPV (Figura 3.c) utilizando las ER AgeI y NheI permitió la clonación de los extremos compatibles de la secuencia Lox2272 anti-sentido, que fueron también diseñados para perder el sitio de clonación AgeI (Figura 3.d). El plásmido pPVI generado tuvo un tamaño de 4,7 kb.

El plásmido pPVII fue generado a partir del pPVI que fue modificado para contener el sitio LoxP anti-sentido en orientación sentido al extremo 5’ de Lox2272 anti-sentido. La linearización de pPVI (Figura 4.a) usando las ER AseI y NheI permitió la consiguiente ligación con el extremo compatible de LoxP anti-sentido, también diseñado para perder el sitio NheI (Figura 4.b) y la introducción de los nuevos sitios de restricción BglII, HindIII y NotI, útiles para posteriores pasos de clonación. El plásmido pPVII resultante tuvo un tamaño de $4,2 \mathrm{~kb}$.

El plásmido pPVIII fue desarrollado con el objetivo de fusionar: 1) eGFP, Lox2272 anti-sentido, y LoxP anti-sentido, pertenecientes al vector pPVII, situados entre los 
sitios de restricción NotI y MuI, y 2) las secuencias del gen de resistencia a la neomicina y del promotor $\mathrm{H} 1$, pertenecientes al plásmido pPIV y situadas entre las secuencias de restricción XmaI y MluI. Para hacer esto, pPIV fue linearizado (Figura 4.c) con las enzimas de restricción NotI y MluI y fueron ligados a un fragmento de $\sim 1.200 \mathrm{pb}$ escindido con las mismas enzimas del vector pPVII (Figura 4.d). El vector resultante tenía un tamaño de 5.426 pb.

El plásmido pPIX fue generado con el objetivo de fusionar: 1) Las secuencias LoxP en orientación sentido, H1, eGFP, Lox2272 anti-sentido y LoxP anti-sentido que estaban presentes en el plásmido pPVIII entre los sitios de restricción XmaI y NotI, y 2) las secuencias del CMV y Lox2272 en orientación sentido contenidas en el plásmido pPI entre los mismos sitios de restricción. El plásmido pPI linearizado (Figura 5.a) con las enzimas NotI y XmaI generó el armazón de un vector de 4 kb que fue ligado con un fragmento de $\sim 2.500 \mathrm{pb}$ del plásmido pPVIII, que fue escindido con las mismas ER (Figura 5.b). El plásmido resultante tuvo un tamaño de 6.5 kb. Este plásmido contiene únicamente un sitio de restricción para BglII y HindIII lo cual es particularmente útil para clonar cualquier shRNA.

El plásmido pPX fue diseñado para escindir el gen de resistencia a la neomicina del plásmido pPIX para usarlo en las microinyecciones. El gen de la neomicina fue eliminado digiriendo el pPIX con las enzimas XmaI y SalI (Figura 5.c) y el esqueleto de $\sim 5.400 \mathrm{pb}$ del vector fue autoligado. Antes de la ligación, los extremos cohesivos generados por ambas enzimas fueron rellenados para producir extremos romos con el fragmento Klenow de la DNA polimerasa. Por lo tanto, se perdieron los sitios de restricción XmaI y SalI (Figura 5.d). Este plásmido contiene únicamente un sitio de restricción para BglII y HindIII para clonar cualquier shRNA (Figura 6.c).

El plásmido $\mathrm{pP} X I$ fue obtenido a partir del plásmido $\mathrm{pP} X$ previamente digerido en sus únicos sitios de restricción, BglII y HindIII (Figura 6.a). El shRNA de extremos compatibles (para el tipo pSuper) fue ligado al vector linearizado, perdiendo el sitio de restricción BglII (Figura 6.b). La representación de la construcción final shGCL ${ }^{\text {floxed }}$ se observa en la Figura 6.d. Esta configuración es el estado no recombinado. 


\section{Generación de los ratones $s h G C L^{\text {floxed }}$}

El plásmido pPXI fue digerido con AflII y AseI para escindir la construcción entera sin ninguna otra secuencia bacteriana y dejando unos 200 nt extra para evitar la hipotética degradación por endonucleasas tras la microinyección de los ovocitos. El fragmento de 2.200 pb (Figura 7.a) fue purificado y resuspendido en tampón de microinyección tras ser cuantificado en un Nanodrop 2000. Los ovocitos prefertilizados de la línea híbrida C57B6/CBA F1 fueron microinyectados con la construcción shGCL ${ }^{\text {floxed }}$ linearizada. Esta línea fue elegida debido a la alta respuesta a la súper-ovulación y la alta resistencia a la punción. Los ovocitos inyectados supervivientes que evolucionaron al estado de 2 células fueron implantados en ratonas CD1 pseudo-preñadas. Los fundadores fueron identificados detectando mediante PCR la construcción shGCL floxed (Figura 7.d) y fueron retrocruzados con ratones silvestres C57Bl/6J. La homogeneidad de la línea C57Bl/6J se incrementó en cada generación (como se describe en el Esquema 3). Los ratones de la F3 fueron utilizados para generar los MEFs. Para los estudios in vivo se cruzaron ratones hemicigotos de la F4 con ratones homocigotos de la línea CamKII $\alpha$ Cre. El genotipo de la progenie se determinó realizando dos PCRs diferentes para la construcción $s h G C L^{\text {floxed }}$ y el trasgén Cre (Figuras 7.b y 7.c). Los genotipos posibles eran: control [CamKII $\alpha-C r e(+/-) / \operatorname{shGCL}(-/-)]$ y knockdown [CamKII $\alpha-C r e(+/-$ )$/ \operatorname{shGCL}(+/-)]$.

Mientras tanto, los ratones shGCL ${ }^{\text {floxed }}$ fueron retrocruzados sucesivamente con ratones C57Bl/6J y, en el momento de la escritura de esta Tesis Doctoral, han alcanzado el estatus de congénicos a las 10 generaciones (F10).

\section{Estado redox de los MEF (Mouse Embrionary Fibroblast, Fibroblastos Embrionarios de Ratón) shGCL floxed}

Se obtuvieron MEFs de los ratones $s h G C L^{\text {floxed }}$ para validar la estrategia implementada.

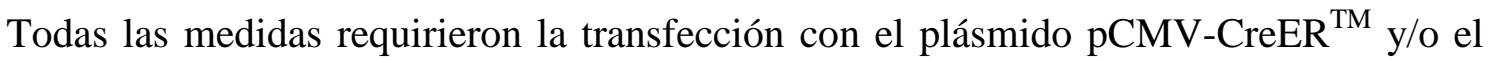
vector vacío. Seis horas tras la transfección con Lipofectamine2000, siguiendo las instrucciones del fabricante, se añadió medio fresco a las células en ausencia (vehículo) o presencia de $1 \mu \mathrm{M}$ 4-hidroxi-tamoxifen (TM) para permitir la translocación de la Cre recombinasa al núcleo y que se produjera la consiguiente recombinación. Se analizó el correcto funcionamiento de la construcción por PCR, en la que se detectaron tanto el estado recombinado como el no recombinado (Figura 8.a). Se observaron bandas 
robustas, correspondientes al estado no recombinado ( 1,000 pb), en los MEFs transfectados con el vector vacío, mientras que se observaron bandas mucho más débiles en las células transfectadas con pCMV-CreER ${ }^{\mathrm{TM}}$. Las células transfectadas con pCMV-CreER ${ }^{\mathrm{TM}}$ y tratadas con TM mostraron las bandas más débiles. Una banda

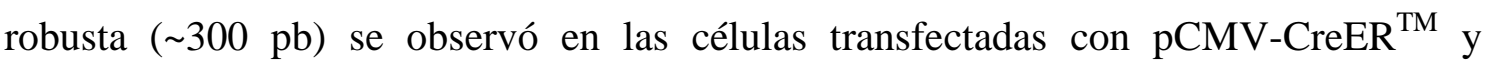
tratadas con TM, mientras que una banda muy débil se observó en las células transfectadas con pCMV-CreER ${ }^{\mathrm{TM}}$ y tratadas con vehículo (Figura 8.a). Tal y como reveló el análisis por western blot utilizando anticuerpos anti GCL, los MEFs shGCL $L^{\text {floxed }}$ transfectados con pCMV-CreER ${ }^{\mathrm{TM}}$ mostraron a las $48 \mathrm{~h}$ y a las $72 \mathrm{~h}$ post transfección (42 h y 66 h tras la adición de TM, respectivamente) un descenso progresivo en la GCL al compararla con los controles (Figura 8.b). A continuación, se midió el $\mathrm{H}_{2} \mathrm{O}_{2}$ y los tioles totales a las 24h tras la adición de TM (o vehículo) en MEFs transfectados con pCMV-CreER ${ }^{\mathrm{TM}}$ o el vector vacío. Como se muestra en las Figuras 9.a y 9.b, el $\mathrm{H}_{2} \mathrm{O}_{2}$ y los tioles totales disminuyeron en los MEFs transfectados con pCMV-CreER ${ }^{\mathrm{TM}}$ por el tratamiento con TM. La concentración de glutatión total (reducido y oxidado) disminuyó (Figura 9.c) tras la transfección con pCMV-CreER ${ }^{\mathrm{TM}}$, independientemente de la ausencia o presencia de TM; sin embargo, la presencia de TM disminuyó aún más la concentración de glutatión total. Cuando se discriminó entre glutatión reducido y oxidado, se demostró un incremento en la forma oxidada sólo cuando las células transfectadas con pCMV-CreER ${ }^{\mathrm{TM}}$ (Figura 9.d) se incubaban con TM. El glutatión reducido disminuyó en las células transfectadas con pCMV-CreER ${ }^{\mathrm{TM}}$ independientemente de la presencia de TM, aunque la presencia del mismo disminuyó aún más la concentración de glutatión reducido e incrementó la del glutatión oxidado (Figura 9.d)

\section{Caracterización bioquímica de los ratones CamKIIa-Cre/shGCL ${ }^{\text {floxed }}$.}

Para explorar el efecto del knockdown de la GCL en las neuronas, los ratones shGCL $L^{\text {floxed }}$ fueron cruzados con ratones CamKII $\alpha$-Cre, que expresan la recombinasa Cre entre los días 14-21 de desarrollo postnatal principalmente en las neuronas del hipocampo y en el prosencéfalo de forma dispersa. El tejido cerebral se extrajo de ratones de 40 semanas de edad de los genotipos CamKII $\alpha$-Cre(+/-)/shGCL(-/-) (control), and CamKII $\alpha-C r e(+/-) / \operatorname{shGCL(+/-)~(knockdown).~El~cerebro~se~diseccionó~en~}$ cerebelo (Cb), estriado (Str), hipocampo (Hip) y córtex prefrontal (PCx). EL DNA extraído del hipocampo fue sometido a análisis mediante PCR para detectar la 
construcción no recombinada y recombinada (Figura 10). La banda correspondiente al estado no recombinado ( $1.000 \mathrm{pb})$ fue detectada en los controles, pero no en los ratones knockdown. Como se muestra en la Figura 10 (panel de la derecha), la banda correspondiente al estado recombinado ( 300 pb) se observó en los knockdown pero no en los ratones control. A continuación, el glutatión total (reducido y oxidado) se midió en los extractos de las áreas cerebrales anteriores (que contienen una mezcla de todos los tipos de células cerebrales). Como se muestra en la Figura 11, no se encontraron diferencias en la concentración de glutatión total entre los grupos control y knockdown en ninguna de las áreas determinadas. Es de reseñar que la concentración de glutatión total se encontró significativamente en menores cantidades en el estriado de estos ratones -sin tener en cuenta el genotipo- cuando se comparó con el resto de las áreas analizadas (Figura 11). Las muestras de cerebros, recogidas del mismo modo que lo descrito anteriormente, se sometieron a una detección de carbonilos oxidados en las proteínas (Figura 12, panel superior), y a una determinación de la cantidad de proteínas totales contenidas (Figura 12, panel inferior) en machos y hembras. Como se muestra, los hipocampos de las hembras knockdown, y los hipocampos y estriados de los machos knockdown mostraron niveles más altos de carbonilos oxidados que en sus respectivos controles.

\section{Caracterización inmunohistoquímica de los ratones CamKII $\alpha-C r e / s h G C L^{\text {floxed }}$.}

Se realizaron varias pruebas histoquímicas e inmunohistoquímicas sobre secciones de $30 \mu \mathrm{m}$ de grosor. Se realizaron microfotografías de hipocampos de secciones cerebrales de ratones CamKII $\alpha-C r e(+/-) / \operatorname{shGCL(-/-)~(control)~and~CamKII~} \alpha-C r e(+/-) / \operatorname{shGCL}(+/-)$ (knockdown). La tinción de Nissl no reveló diferencias importantes en la citoarquitectura o en el espesor de la capa (Figura 13). A continuación se realizaron inmunotinciones para detectar cambios en el estado redox, como marcador del índice de estrés oxidativo. Se tomaron imágenes confocales para detectar colocalizaciones y para realizar una adquisición secuencial para discriminar las distintas fluorescencias de los fluoróforos utilizados (Alexa 488 y Alexa 594). En el momento en el que se escribe esta Tesis, la cuantificación de todas las imágenes está todavía incompleta, por lo que las imágenes mostradas se analizan de forma cualitativa. Para el marcaje de la GCL (Figura 14), no se encontraron diferencias destacadas entre los machos control y knockdown, probablemente debido a los bajos niveles detectables de GCL en el cerebro previamente descritos (Godoy et al., 2011). Como reveló el anticuerpo anti-GSH (Figura 15), los 
machos knockdown parecen tener menos proteínas glutationiladas. El marcaje anti 3nitrotirosina (Figura 16) reveló un nivel mayor de proteínas nitradas en los machos knockdown respecto a los control. En todos los casos, aparecieron puntos densos que colocalizaban nítidamente con los marcadores de estrés oxidativo 3-nitrotirosina y GSH. Su aspecto parece corresponderse con una localización vesicular o formando agregados proteicos. Interesantemente, el marcaje de la CamKII $\alpha$-que se realizó para detectar colocalización- reveló un incremento en los niveles de la proteína CamKII $\alpha$ en los machos knockdown respecto a los controles (Figs. 14 y 16). Debería ser resaltado, sin embargo, que este efecto es difícil de ver con la imagen mostrada en la Figura 14. En este contexto, tenemos que explicar que el fluoróforo utilizado fue distinto en ambos experimentos, utilizando Cy5 en el primero y Alexa 594 en el último. La diferencia parece ser debida fundamentalmente a la forma fosforilada de CamKII $\alpha$, según se muestra en los resultados de la Figura 15.

\section{Caracterización comportamental de los ratones CamKIIa-Cre/shGCL ${ }^{\text {floxed }}$.}

Para todos los test comportamentales utilizamos los genotipos CamKII $\alpha$-Cre $(+/-$ )/shGCL(-/-) (control) and CamKII $\alpha-C r e(+/-) / \operatorname{shGCL(+/-)~(knockdown).~Los~datos~se~}$ muestran o bien según el genotipo $(n \geq 12)$ o bien según sexo y genotipo $(n \geq 6)$. La coordinación motora y el equilibrio, medidos por el test del Rotarod, mostró estar alteraciones en los ratones knockdown desde las 25 semanas de edad en adelante (Figura 17.a), cuando la actuación de los machos contribuyó mayoritariamente a la deficiente capacidad de realización del test (Figura 17.b). El miedo/ansiedad se determinó tanto con el test de Campo Abierto como con el test Hole-Board. No se observaron diferencias cuando los datos se trataron como independientes de sexo (datos no mostrados). Sin embargo, cuando el sexo se tomaba como variable, las hembras knockdown recorrían menores distancias (Figura 18.a) y pasaban menos tiempo en la zona centro que sus respectivos controles (Figura 18.b), indicando más miedo/ansiedad. El número de veces que introducían el hocico para explorar, medidos en el test de HoleBoard (Figura 19), reveló una disminución en las introducciones de hocico en las hembras knockdown de 19 semanas de edad respecto a las controles, indicando más miedo/ansiedad. Finalmente, la memoria espacial fue medida utilizando el test del laberinto de brazos radiales (Figura 20). A la luz de los datos obtenidos determinando la tasa de exploraciones correctas respecto al número total de ratones (panel de la izquierda) y el número de errores cometidos (panel derecho), los ratones machos control 
realizaron mejor la tarea que las hembras control; sin embargo, esta capacidad de los machos se deterioró en el grupo knockdown. 


\section{Discusión}

En la presente tesis hemos diseñado y generado una nueva herramienta para interferir específicamente en la síntesis de cualquier proteína, de forma específica de tejido y también regulada temporalmente, basada en la estrategia Cre-LoxP, una técnica que revolucionó el análisis de la expresión genética en ratones (Nagy, 2000). Nuestra herramienta es útil para cualquier tejido, y deja a un lado las clásicas dificultades encontradas a la hora de manipular genéticamente el cerebro. Así, anteriores estrategias e intentos estuvieron basados en sistemas inducibles por doxiciclina, que apenas conseguía cruzar la barrera hematoencefálica (Branda and Dymecki, 2004; Chinta et al., 2007). Nuestro sistema inducible, en cambio, se basa en la Cre recombinasa, que es sensible al tamoxifeno, un compuesto que es capaz de penetrar la barrera hematoencefálica (Danielian et al., 1993). Además, la dosis del fármaco que es necesaria para promover la recombinación está definida (Hirrlinger et al., 2006), minimizando así posibles efectos secundarios indeseados. Al poco tiempo de empezar este trabajo, apareció una tecnología similar basada en shRNA, utilizando también el sistema Cre-LoxP (Fritsch et al., 2004). Sin embargo, descartamos utilizar tal construcción para nuestros objetivos por sus posibles efectos inespecíficos. Tal construcción de shRNA estaba interrumpida por un cassette de neomicina flanqueado por secuencias Lox, para ser escindido en un evento de recombinación con Cre. Tal disposición en esos elementos no evita que el promotor $\mathrm{H} 1$ transcriba un shRNA, que podría exhibir efectos inespecíficos que variaban para cada shRNA clonado. Nuestra construcción, por el contrario, contiene una señal de fin de transcripción del promotor H1 situada inmediatamente después del promotor H1 en orientación anti-sentido, previniendo así la síntesis del shRNA en el estado no recombinado. Adicionalmente, nuestra estrategia es versátil, ya que sólo requiere un sencillo paso de clonación del shRNA entre los sitios de restricción BglII y HindIII , como ocurre con la tecnología ampliamente utilizada pSuper (oligoengine).

Se han descrito ratones knockout (KO) para la GCL (Dalton et al., 2000; Shi et al., 2000); sin embargo los ratones KO para la subunidad catalítica de la GCL no son viables más allá del octavo día de desarrollo embrionario y los heterocigotos muestran una serie de mecanismos de compensación que los excluyen para entender plenamente el papel específico jugado por la GCL en su fenotipo; además, ese modelo KO para la 
GCL no es específico de un tejido ni está regulado temporalmente. Decidimos implementar la tecnología del shRNA, en vez del KO condicional, porque creímos que podría asemejarse más a las condiciones fisiopatológicas. De hecho, una deficiencia media de GCL se ha demostrado induciendo mutaciones específicas en la región codificante del gen de la subunidad catalítica de la GCL (Dalton et al., 2004). Otra ventaja de la estrategia del shRNA sobre el KO son una metodología más fácil y el no requerimiento de homocigosis para el funcionamiento del shRNA, mientras que en general, los animales $\mathrm{KO}$ requieren a veces el estudio en homocigosis ya que los animales heterocigotos pueden presentar fenotipos intermedios, si es que los hay. Durante el curso de la generación y caracterización de nuestro ratón shGCL $L^{\text {floxed }}$ apareció un artículo mostrando alteraciones inducibles de la GCL en neuronas dopaminérgicas (Chinta et al., 2007). Ese sistema se basa en una inducción muy pobre con doxiciclina, que requiere la administración de la droga durante toda la duración del experimento. Además, la aproximación que los autores implementaron para el knockdown de la GCL fue mediante un cDNA anti-sentido contra todo el gen de la GCL, que es muy poco fiable a la vista de los posibles efectos inespecíficos. En vez de eso, seleccionamos una secuencia de shRNA altamente específica basada en criterios racionales y bien contrastados (Birmingham et al., 2007; Naito and Ui-Tei, 2012; Pei and Tuschl, 2006) que habían demostrado previamente ser eficientes y específicos en cultivo primario de neuronas (Diaz-Hernandez et al., 2005).

La construcción shGCL $L^{\text {floxed }}$ se recombina efectivamente tras la actividad de la Cre recombinasa, como demostramos en MEFs cultivados e in vivo. El pequeño evento de recombinación observado en MEFs transfectados con pCMV-CreER ${ }^{\mathrm{TM}}$, en ausencia de tamoxifeno, se debe probablemente al alto número de copias insertadas, aunque también al suero con estradiol presente en el medio de cultivo. CreER ${ }^{\mathrm{TM}}$ está secuestrada en el citosol por la chaperona Hsp90, y se transloca al núcleo cuando existen altas concentraciones de tamoxifeno, ya que $\mathrm{CreER}^{\mathrm{TM}}$ es normalmente insensible a las concentraciones fisiológicas de estradiol (Danielian et al., 1998; Mattioni et al., 1994). Sin embargo, la capacidad de Hsp90 para secuestrar altas cantidades de $\mathrm{CreER}^{\mathrm{TM}}$ como las presentes cuando se sobre expresa pCMV-CreER ${ }^{\mathrm{TM}}$ - junto con la presencia de excesivas concentraciones de estradiol- podría explicar el pequeño fenómeno de "fuga" observado. In vivo, la construcción shGCL $L^{\text {floxed }}$ se recombina eficientemente cuando los ratones $s h G C L^{\text {floxed }}$ se cruzan con los CamKII $\alpha$-Cre. La eficacia de la recombinación 
observada por análisis mediante PCR indica la existencia de fenómenos de recombinación exclusivamente en el hipocampo de ratones knockdown, pero no en los controles.

El knockdown de la GCL promovió un descenso en la concentración de glutatión, en particular en la forma GSH, y un incremento en la forma GSSG en cultivos de MEFs shGCL $L^{\text {floxed }}$ transfectados con $\mathrm{pCMV-CreER}{ }^{\mathrm{TM}}$. Este efecto fue intermedio en la ausencia de tamoxifeno, pero se potenció ampliamente en presencia de la droga. Como se menciona arriba, el pequeño efecto sobre la concentración de glutatión observado en ausencia de tamoxifeno, puede ser adscrito al fenómeno de “fuga” del CreER ${ }^{\mathrm{TM}}$. Este efecto de “fuga” de la expresión de CreER ${ }^{\mathrm{TM}}$ en ausencia de TM no se observó en las concentraciones de tioles totales y $\mathrm{H}_{2} \mathrm{O}_{2}$, que sólo sufrieron alteraciones si se trataba con TM. Esto sugiere la existencia de un umbral de deficiencia de glutatión a la hora de afectar significativamente la oxidación de los sulfidrilos de las proteínas y la eficacia de los MEFs para eliminar $\mathrm{H}_{2} \mathrm{O}_{2}$. In vivo, las concentraciones de glutatión no se vieron afectadas en las muestras de tejido obtenidas de diferentes áreas cerebrales de los ratones CamKII $\alpha$-Cre/shGCL ${ }^{\text {floxed }}$. Deberíamos remarcar que esas muestras contienen una mezcla de todos los tipos de células neurales, y asumiendo que la concentración de glutatión en las neuronas es de $\sim 2.5 \mathrm{mM}$ y $\sim 3.5 \mathrm{mM}$ en los astrocitos (Zeevalk et al., 2008), y que existe una ratio neurona:astrocito de 1:3 en los roedores (Nedergaard et al., 2003), sería inviable detectar con exactitud el descenso previsto de las concentraciones de glutatión en los extractos cerebrales. Por lo tanto, no hay por qué descartar un descenso en la concentración de glutatión en las neuronas in vivo del ratón CamKII $\alpha$ Cre/shGCL $L^{\text {floxed }}$. Este inconveniente no ha afectado, a pesar de ello, a la detección de carbonilos oxidados en extractos totales del cerebro, ya que la acumulación de éstos fue considerable. Además, no es de extrañar que neuronas susceptibles de ser dañadas puedan alterar la homeostasis de las células a su alrededor - incluso a los astrocitos. Los carbonilos oxidados parecen incrementarse en el hipocampo de ratones hembra knockout y, en un grado mucho mayor, en los machos knockdown. Incluso un nivel incrementado de carbonilos oxidados se ha visto en el estriado de machos knockdown. Ya que la expresión de Cre de los ratones CamKII $\alpha$-Cre es más activa en estas áreas cerebrales (Laboratorios Jackson), nuestros datos de los carbonilos oxidados sugieren fuertemente que el ratón CamKII $\alpha$-Cre/shGCL floxed es una herramienta eficiente para disparar endógenamente el estrés oxidativo de las neuronas in vivo. 
La tinción de Nissl muestra que la citoarquitectura o el grosor de las capas del hipocampo del ratón CamKII $\alpha-C r e / s h G C L^{\text {floxed }}$ no están afectados. En el momento en el que está Tesis Doctoral está siendo escrita, estamos realizando análisis inmunohistoquímicos en profundidad, lo que requiere mucho tiempo. Además, decidimos estudiar los machos en primer lugar a la vista de que, i) presentan más carbonilos oxidados que las hembras, y ii) sus alteraciones comportamentales son menos sutiles que en las hembras -como discutiremos más adelante. Por lo tanto, hasta que el recuento total de las imágenes esté completo, sólo podemos aportar datos cualitativos para el estudio inmunohistoquímico en los machos. En general, las imágenes confocales permiten conocer la colocalización y discriminar las intensidades de fluoróforos determinados -adquisición secuencial-, lo que evalúa los cambios en los niveles de intensidad de los marcadores. Las imágenes confocales anti-GCL no pudieron determinar con certeza una clara disminución en la intensidad de la señal de la GCL, un hecho que es debido probablemente a los bajos niveles detectables de la GCL en el cerebro (Godoy et al., 2011). Sin embargo, no podemos descartar problemas derivados del anticuerpo usado; deberíamos mencionar que hay una pobre oferta de anticuerpos comerciales anti-GCL para inmunohistoquímica. Nos gustaría destacar que nuestro ratón $s h G C L^{\text {floxed }}$ ha sido cruzado con un ratón con Cre específica de páncreas en el laboratorio del profesor Juan Sastre (Universidad de Valencia) y los resultados preliminares muestran un descenso de $\sim 60 \%$ en la GCL pancreática en western (Juan Sastre, comunicación personal). Estos datos confirman la utilidad de nuestra aproximación con shGCL floxed para knockdown la GCL de forma específica según el tejido. Además, se observó una disminución de las proteínas glutationiladas del cerebro del ratón CamKII $\alpha$-Cre/shGCL ${ }^{\text {floxed }}$, infiriendo una baja disponibilidad de GSH para glutationilar proteínas (Franco and Cidlowski, 2009). Por otra parte, se detectó una acumulación de proteínas nitradas, evidenciando un incremento en el estrés oxidativo. Los puntos densos que colocalizan nítidamente para la 3-nitrotirosina y el GSH necesitan un estudio detallado, ya que parecen corresponder o a una localización vesicular o a agregados proteicos. Interesantemente, el marcaje para CamKII $\alpha$ era más intenso en los machos knockdown que en los controles, a juzgar por las imágenes mostradas en las Figuras 14 y 16; sin embargo, la mayor intensidad de marcaje no era tan evidente en la Fig. 14. Debemos aclarar que el fluoróforo usado era diferente en ambos experimentos; Cy5 en el primero y Alexa594 en el segundo. También 
observamos mayor intensidad en la forma fosforilada de la CamKIIa (Fig. 15). Es necesario realizar ulteriores estudios teniendo en cuenta una posible relación entre este resultado y las alteraciones cognitivas -que discutiremos a continuación-; de hecho, CamKII $\alpha$ tiene un papel crítico en el aprendizaje y la memoria (Yamauchi, 2005).

Los test de comportamiento arrojaron conclusiones mezcladas dependiendo del sexo, de las cuales no tenemos todavía una explicación convincente. Las diferencias en los niveles de estrógeno circulante, mucho mayores en hembras, podrían ser responsables de una mejor protección ante el estrés oxidativo (Behl et al., 1995); sin embargo, este dato necesita ser confirmado. Respecto al equilibrio motor y los test de coordinación mostramos que los machos knockdown muestran deterioro locomotor, mientras que las hembras knockdown no. A la vista de que la detección de carbonilos oxidados era mayor en el estriado de los machos knockdown, pero no en las hembras, esto sugiere fuertemente una relación directa entre el estrés oxidativo en el estriado y los problemas locomotores. Esto es, según nuestros conocimientos, la primera prueba in vivo que muestra que el estrés oxidativo en el estriado podría ser un desencadenante de problemas de coordinación motora en ciertas enfermedades, como en el Parkinson. Notablemente, la capacidad cognitiva de los machos control era mejor que las hembras control; sin embargo, la mejora en la memoria espacial se perdió en los machos knockdown. En este contexto hay un estudio previo en el que se relaciona el estrés oxidativo y problemas en la memoria en un modelo murino de deficiencia de GSH de cuerpo entero (Chen et al., 2012). Desafortunadamente, no se tuvieron en cuenta las diferencias en cuanto al sexo y el estrés oxidativo se producía en las células de todo el cuerpo, por lo tanto evitando obtener una relación directa causa-efecto (Chen et al., 2012). Según nuestros test, las hembras knockdown mostraron signos significativos aunque leves- de miedo/ansiedad; en este contexto se sabe que el estrés oxidativo está asociado con la patogénesis de la ansiedad. Así, la depresión experimental inducida por un shock en ratones causa una deficiencia leve en la concentración cerebral de glutatión (Pal and Dandiya, 1994). Además una deficiencia leve en todas las células de un ratón transgénico induce un comportamiento sintomático compatible con la ansiedad (Chen et al., 2012); desafortunadamente, esta deficiencia en todo el cuerpo de GSH causó fallo hepático debido al estrés oxidativo que condujo secundariamente a un desequilibrio metabólico que desencadenó un estado patológico generalizado dañando todos los tejidos, además del cerebro. Sin embargo, en la ansiedad sólo están afectadas las 
neuronas del hipocampo (Rosen and Schulkin, 1998), por lo tanto nuestros datos sugieren que el estrés oxidativo específico de las neuronas podría ser una causa de ansiedad.

En conclusión, describimos una nueva estrategia para estudiar el estrés oxidativo in vivo de forma controlada en el tejido y en el tiempo. Este modelo podría abrir nuevas posibilidades en el estudio del papel de niveles elevados de ROS en enfermedades mentales, como el Alzheimer o la ansiedad, que son intrínsecos a varios desórdenes psiquiátricos como la depresión, ataques de pánico, fobias, trastorno obsesivo compulsivo y estrés post-traumático (Gross and Hen, 2004); sin embargo estas enfermedades carecen adecuadamente de modelos in vivo para investigar nuevas estrategias terapéuticas. Además, ya que diseñamos una herramienta genética con dos únicos sitios de restricción flanqueando la secuencia de shRNA, se podrían generar nuevos modelos animales knockdown para cualquier otra proteína de manera específica en cada tejido in vivo. Creemos que el ratón transgénico aquí descrito podría ser útil para una mejor comprensión de las consecuencias del estrés oxidativo en las células in vivo, así como para dirigir nuevas aproximaciones farmacéuticas.

\section{Figuras y Esquemas}




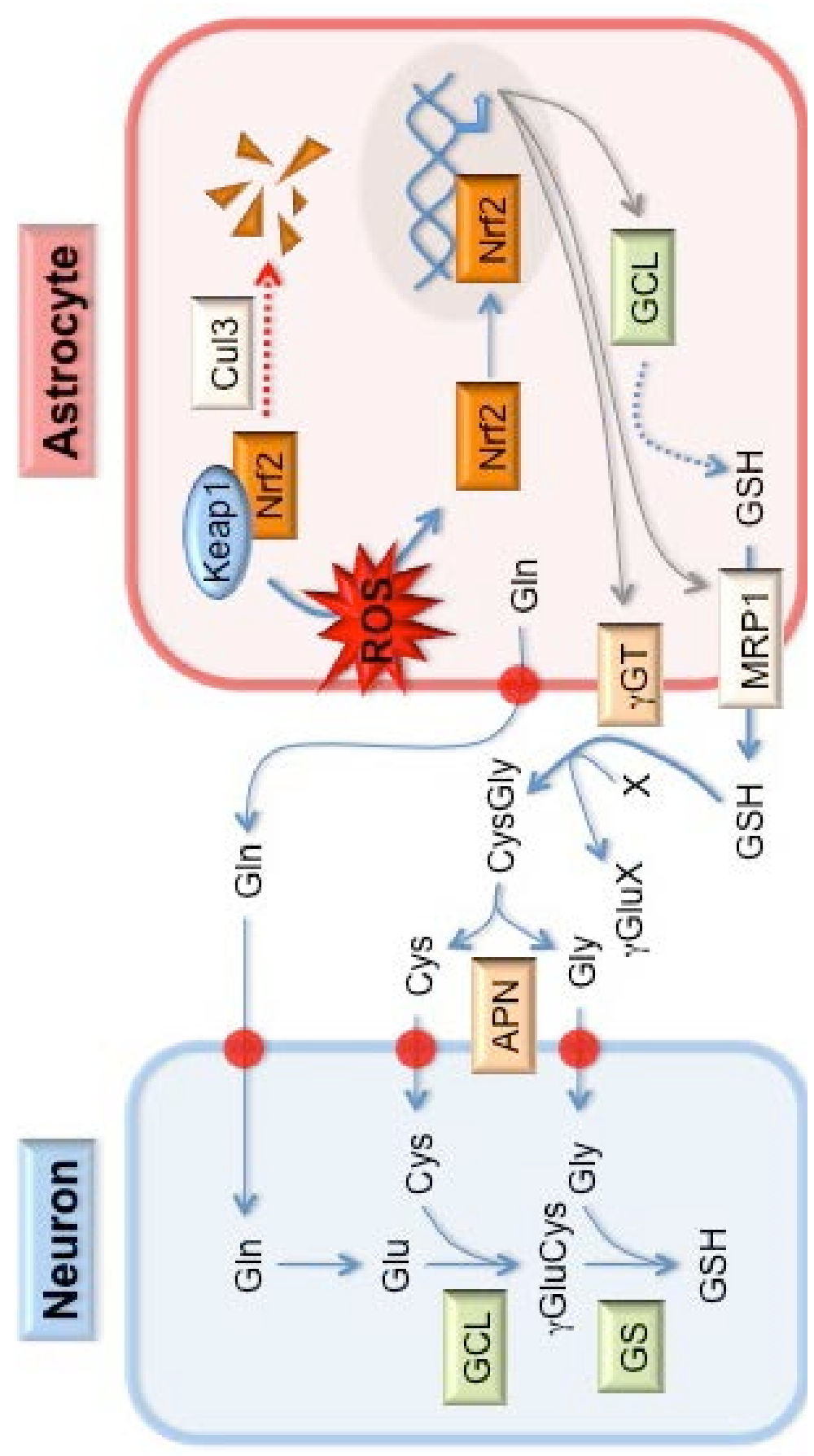

정 क क

은 夏 $\overline{0}$

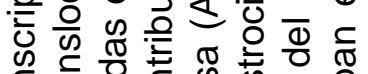

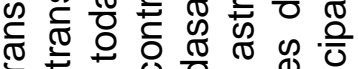

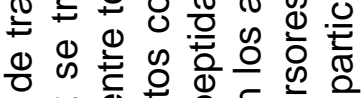
ㄴำ

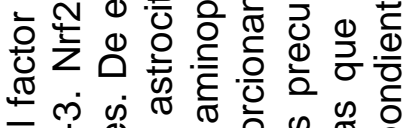
ब)

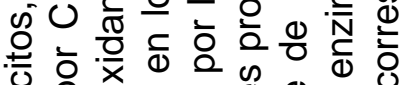

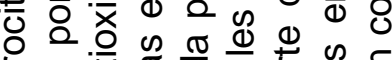

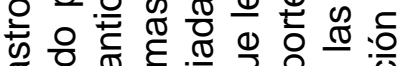

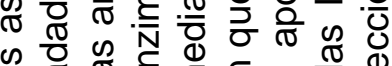

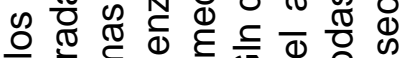

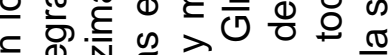

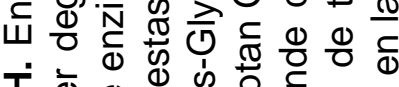

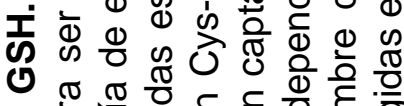

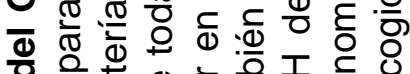

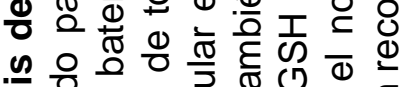
क ญ 它

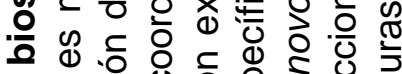
뜨 $>$ 응 0 응

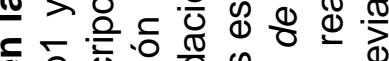

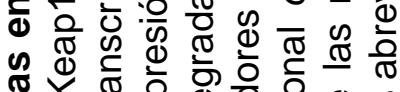

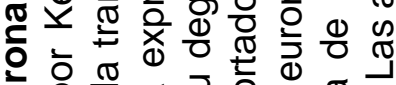

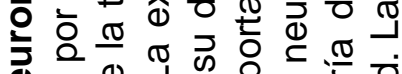

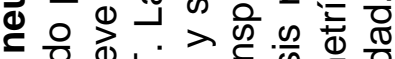

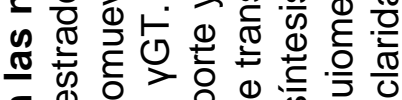

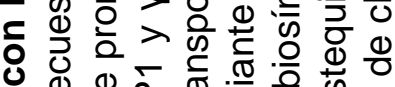
0 \& क क 过 需 $\overline{0}$ 흥

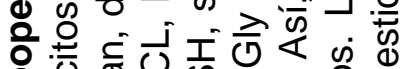

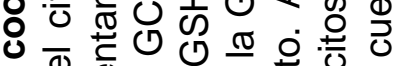

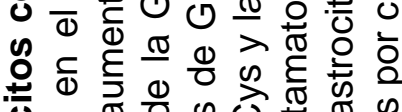
잉

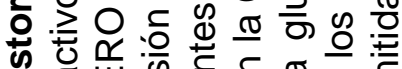

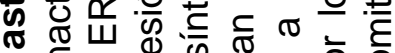
क $\cong$ क

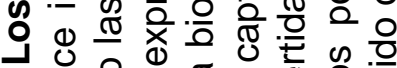
d 응 뜨 को ᄀ

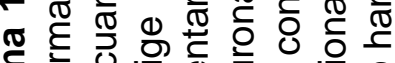

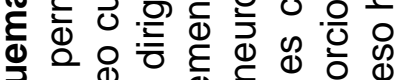

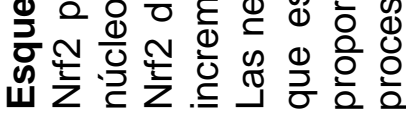


a)

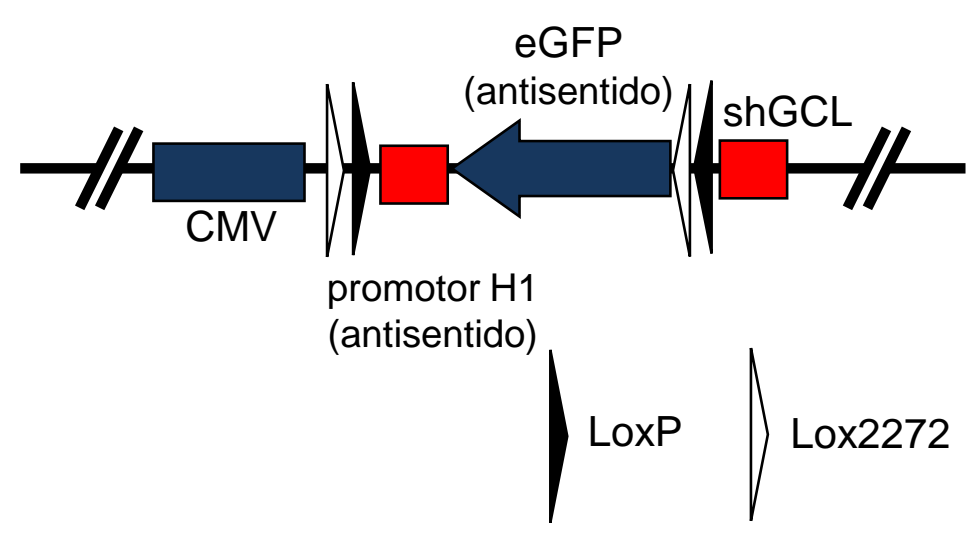

b)

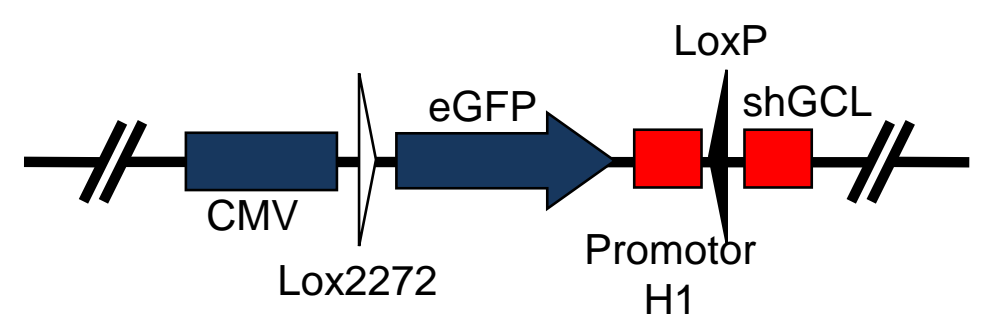

Esquema 2. Funcionamiento de la construcción shGCLfloxed. a) Configuración de los elementos de la construcción de cDNA shGCL floxed antes de la recombinación mediada por Cre. El promotor del CMV y las secuencias del shGCL están dispuestas en orientación sentido, mientras que el promotor $\mathrm{H} 1$ y la secuencia de la eGFP están situadas en orientación anti-sentido. Las secuencias Lox 2272 (puntas de flecha blanca) y LoxP (puntas de flecha negra) están situadas tanto en orientación sentido como en anti-sentido. b) Configuración de los elementos de la construcción shGCL floxed tras la recombinación mediada por Cre. Todos los elementos, excepto LoxP, están situados en otrientación sentido. Esta configuración es estable y no es susceptible de sufrir ningún episodio adicional de recombinación. 
a)

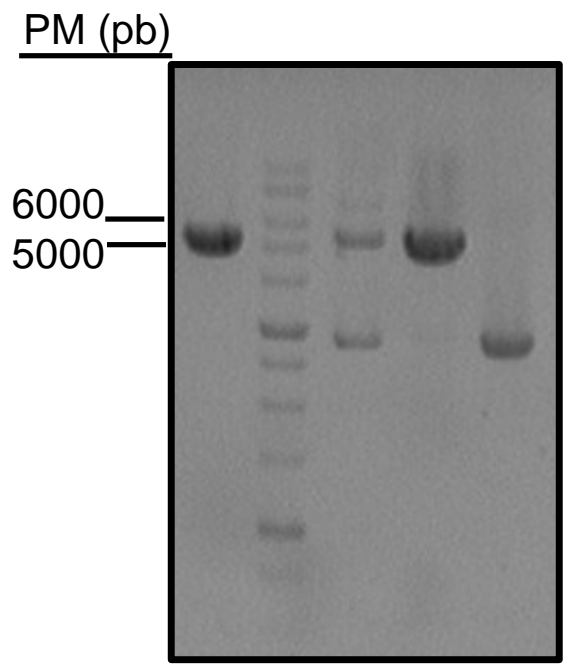

Carril : $1 \quad 2 \quad 3 \quad 4 \quad 5$

c)

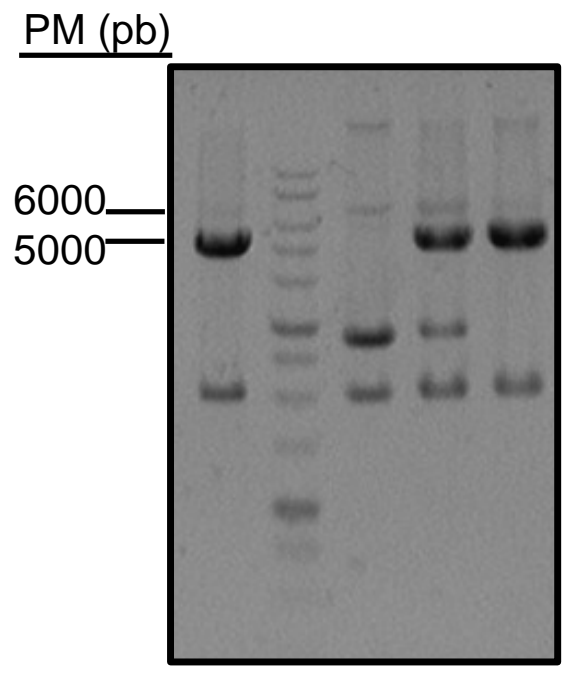

Carril : $1 \quad 2 \quad 3 \quad 4 \quad 5$ b) $\mathrm{PM}(\mathrm{pb})$

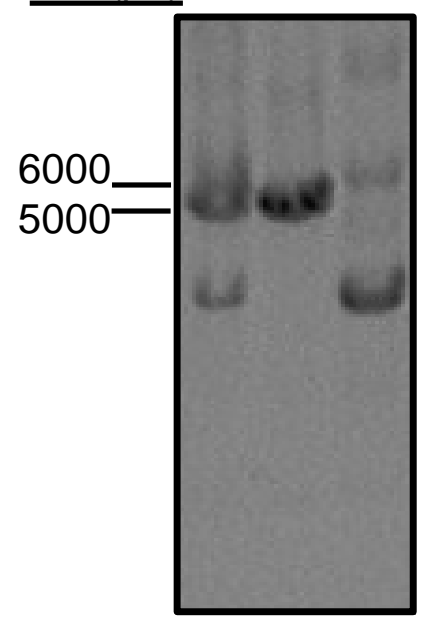

Carril : 1223

d) $\mathrm{PM}(\mathrm{pb})$

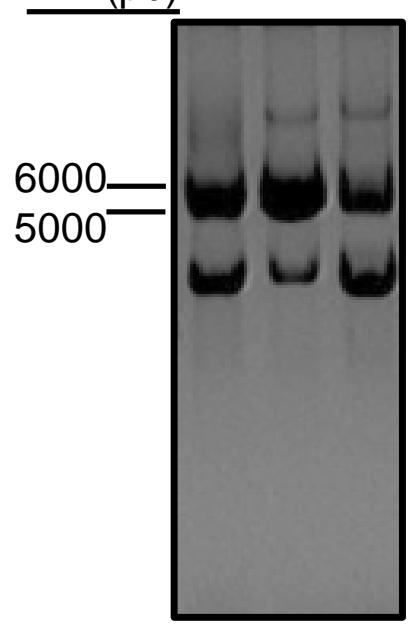

Carril : $1 \quad 2 \quad 3$

Figura 1. Los plásmidos pPI y pPII están ensamblados correctamente. Se muestran los geles en colores invertidos para mejorar su visualización. a) Digestión pIRES2-eGFP. Carril 1: doble digestión con Nhel y Xmal. Se genera un plásmido linearizado de $5.3 \mathrm{~kb}$; carril 2: Marcador de peso molecular $(1 \mathrm{~kb})$ de Biotools; carril 3: control positivo con Nhel; carril 4: control positivo con Xmal; carril 5: control negativo (sin digerir). b) Confirmación de la ligación de pPI . Carril 1: negativo para Nhel; carril 2: tamaño correcto para la digestión con Xmal; carril 3: control negativo (sin digestión). c) Digestión de pSuper.neo-gfp. Carril 1: doble digestión con Bglll y Xhol. Se genera un plásmido linearizado de 5.4 kb; ; carril 2: Marcador de peso molecular (1 kb) de Biotools; carril 3: control positivo con Bglll; carril 4: control positivo con Xhol; carril 5: control negativo (sin digerir). d) Confirmación de la ligación de pPII. Carril 1: negativo para Bglll; carril 2: negativo para Xhol; carril 3: control negativo (sin digerir). 
a)

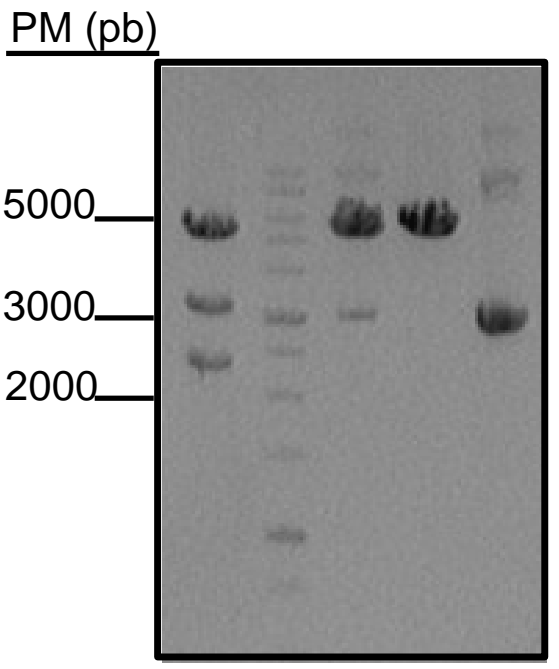

Carril : $1 \quad 2 \quad 3 \quad 4 \quad 5$

c) $\underline{P M(p b)}$

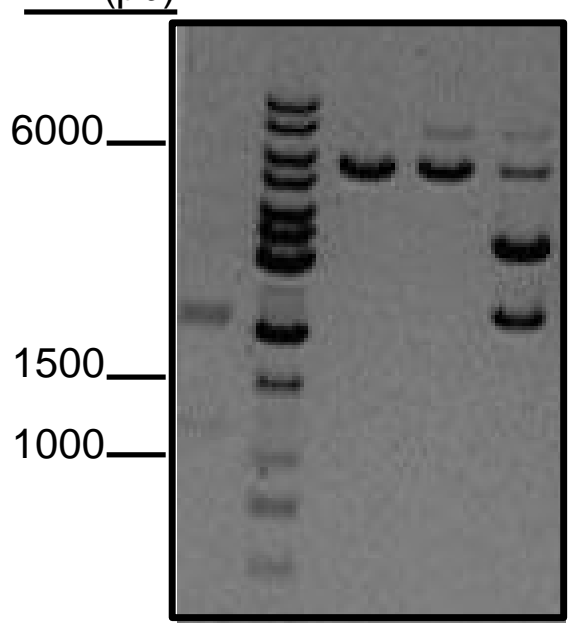

Carril : $1 \quad 2 \quad 3 \quad 4 \quad 5$ b) $\mathrm{PM}(\mathrm{pb})$

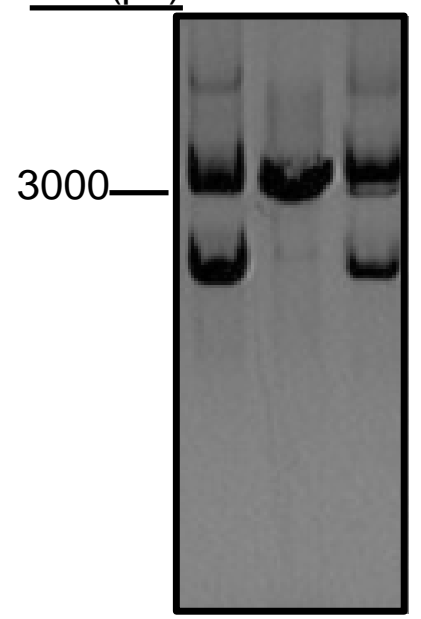

Carril : $1 \quad 2 \quad 3$

d) $\mathrm{PM}(\mathrm{pb})$

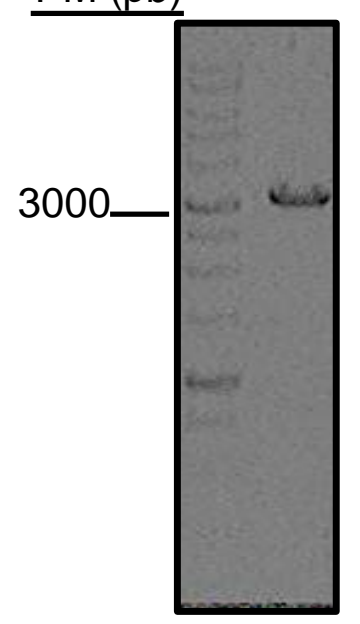

Carril : 12

Figura 2. los plásmidos pPIII and pPIV están ensamblados correctamente. Se muestran los geles en colores invertidos para mejorar su visualización. a) Digestión de pPII. Carril 1: digestión doble con EcoRI y Notl. Se genera un plásmido linearizado de $3 \mathrm{~kb}$; carril 2: : Marcador de peso molecular $(1 \mathrm{~kb})$ de Biotools; carril 3: control positivo con EcoRl; carril 4: control positivo con Notl; carril 5: control negativo (sin digerir). b) Confirmación de la ligación de pPIII . Carril 1: carril negativo para EcoRl; carril 2: Tamaño correcto para para Xhol; carril 3: control negativo (sin digerir). c) Digestión de pCDNA3.1(+). Carril 1: digestión doble con Sall y Xmal. Se genera un fragmento de 1,2kb correspondiente al gen de resistencia a la neomicina; carril 2: Marcador de peso molecular (1 kb) de Biotools; carril 3: control positivo con Sall; carril 4: control positivo con Xmal; carril 5: control negativo (sin digerir). d) Digestión de pPIII . Carril 1: Marcador de peso molecular (1 kb) de Biotools; carril 2: digestión doble con Sall y Xmal. Se genera un plásmido linearizado de $3 \mathrm{~kb}$. 
a)

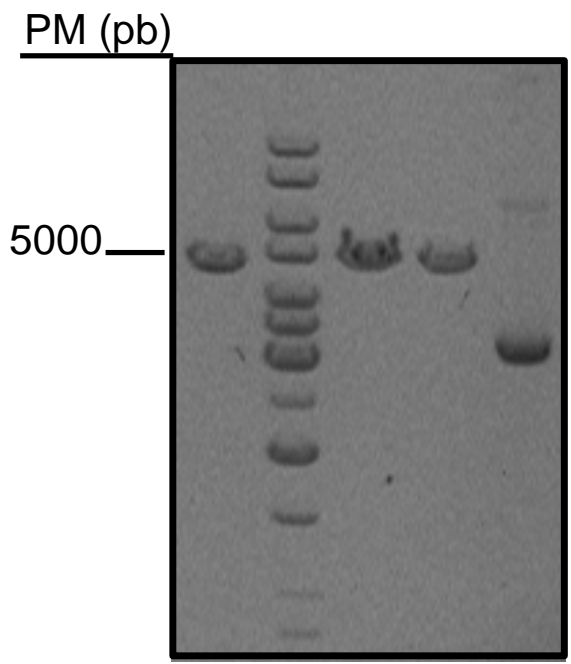

Carril : $1 \quad 2 \quad 3 \quad 4 \quad 5$

c) $\mathrm{PM}(\mathrm{pb})$

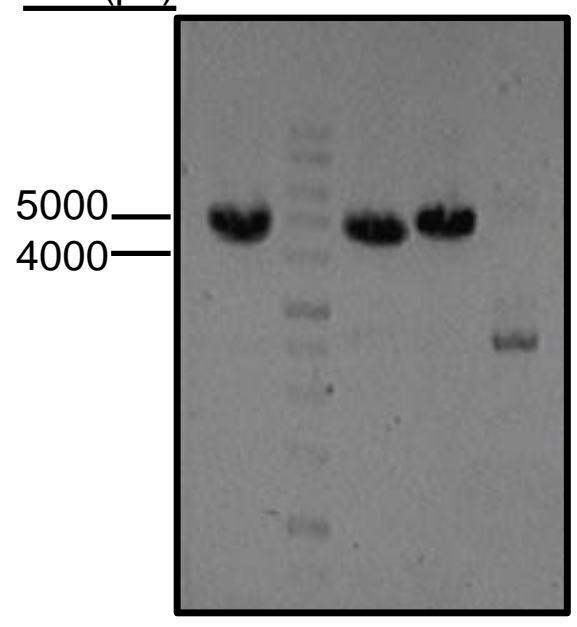

Carril : $1 \quad 2 \quad 3 \quad 4 \quad 5$ b) $\mathrm{PM}(\mathrm{pb})$

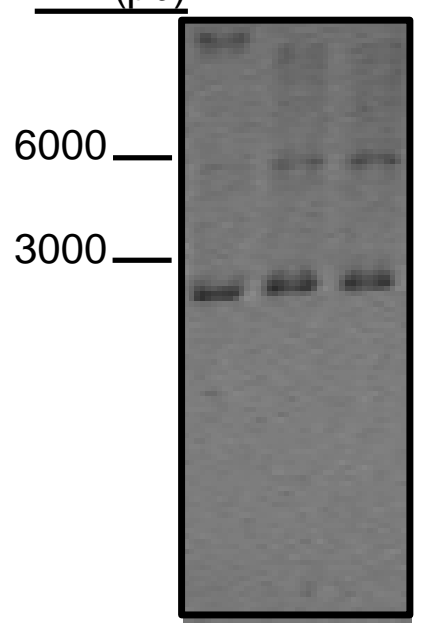

Carril : $1 \quad 2 \quad 3$

d) $\mathrm{PM}(\mathrm{pb})$

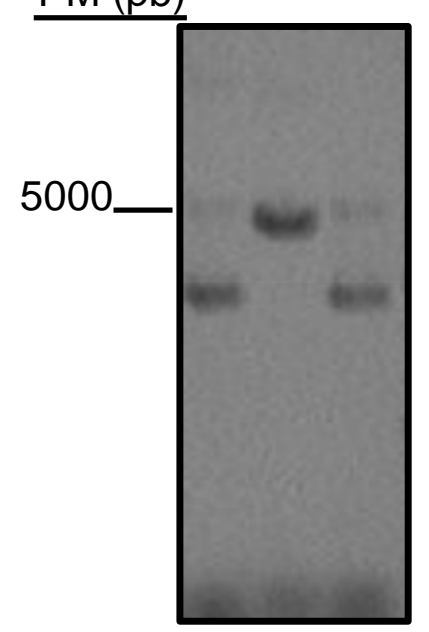

Carril : $1 \quad 2 \quad 3$

Figura 3. Los plásmidos pPV y pPVI están ensamblados correctamente. Se muestran los geles en colores invertidos para mejorar su visualización. a) Digestión de peGFP-C1. Carril 1: digestión doble con Bglll y BamHI. Se genera un plásmido linearizado de $4.7 \mathrm{~kb}$; carril 2: : Marcador de peso molecular (1 kb) de Biotools; carril 3: control positivo con Bglll; carril 4: control positivo con BamHI; carril 5: control negativo (sin digerir). b) Confirmación de la ligación de pPV. Carril 1: negativo para Bglll; carril 2: negativo para BamHI; carril 3: control negativo (sin digerir). c) Digestión de pPV. Carril 1: digestión doble con Agel y Nhel. Se genera un plásmido linearizado de $4.6 \mathrm{~kb}$; carril 2: : Marcador de peso molecular $(1 \mathrm{~kb})$ de Biotools; carril 3: control positivo con Agel; carril 4: control positivo con Nhel; carril 5: control negativo (sin digerir). d) Confirmación de la ligación de pPVI. Carril 1: negativo para Agel; carril 2: tamaño correcto para la digestión con Nhel; carril 3: control negativo (sin digerir). 
a)

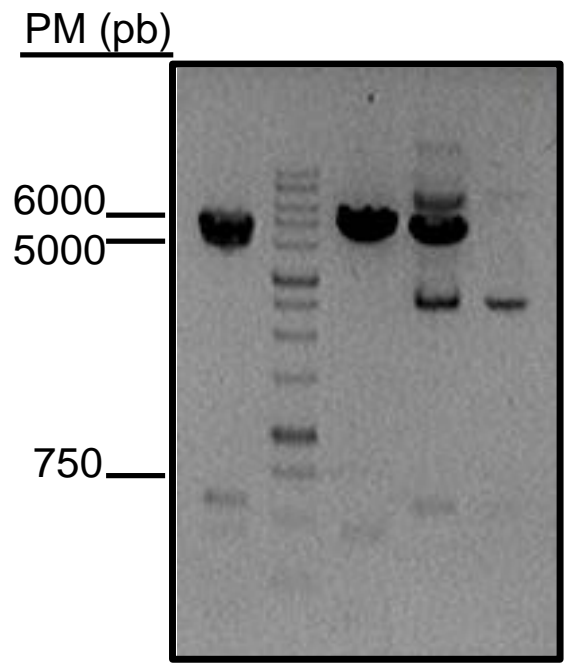

Carril : $1 \quad 2 \quad 3 \quad 4 \quad 5$

c) $\mathrm{PM}(\mathrm{pb})$

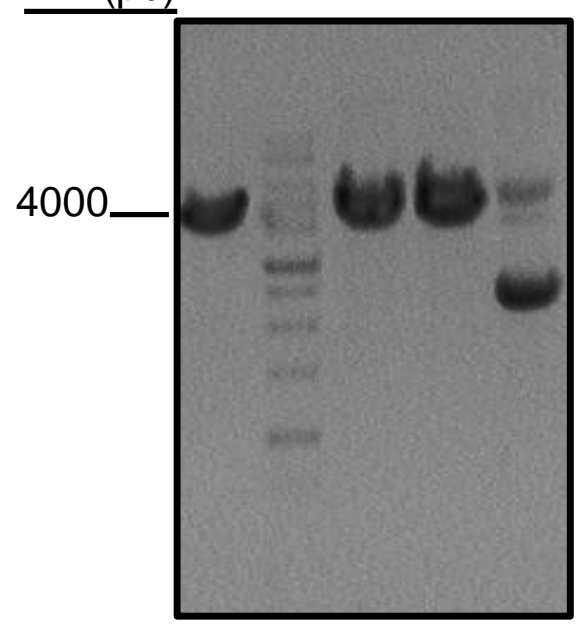

Carril : $1 \quad 2 \quad 3 \quad 4 \quad 5$ b) $\mathrm{PM}(\mathrm{pb})$

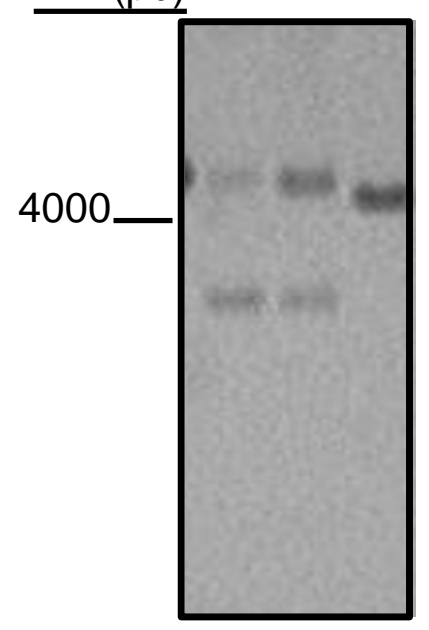

Carril : $1 \quad 2 \quad 3$

d) $\mathrm{PM}(\mathrm{pb})$

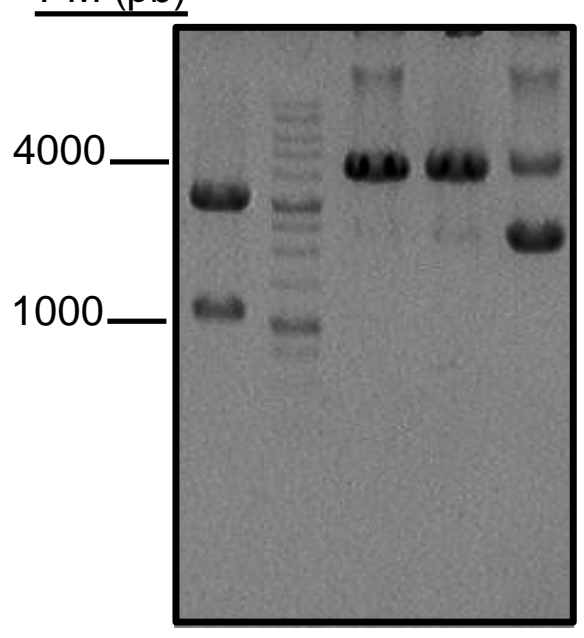

Carril : $1 \quad 2 \quad 3 \quad 4 \quad 5$

Figura 4. Los plásmidos pPVII y pPVIII están ensamblados correctamente. Se muestran los geles en colores invertidos para mejorar su visualización. a) Digestión de pPVI. Carril 1: digestión doble con Asel y Nhel. Se genera un plásmido linearizado de $3 \mathrm{~kb}$; carril 2: : Marcador de peso molecular $(1 \mathrm{~kb})$ de Biotools; carril 3: control positivo con Asel; carril 4: control positivo con Nhel; carril 5: control negativo (sin digerir). b) Confirmación de la ligación de pPVII. Carril 1: control negativo (sin digerir); carril 2: negativo para Nhel; carril 3: tamaño correcto para la digestión con Asel. c) Digestión de pPIV. Carril 1: digestión doble con Notl y Mlul. Se genera un plásmido linearizado de $4.3 \mathrm{~kb}$; carril 2: Marcador de peso molecular (1 kb) de Biotools; carril 3: control positivo con Notl; carril 4: control positivo con Mlul; carril 5: control negativo (sin digerir). d) Digestión de pPVII. Carril 1: digestión doble con Notl y Mlul. Se genera un fragmento de $1.2 \mathrm{~kb}$; carril 2: Marcador de peso molecular (1 kb) de Biotools; carril 3: control positivo con Notl; carril 4: control positivo con Mlul; carril 5: control negativo (sin digerir). 
a) $\underline{P M(p b)}$

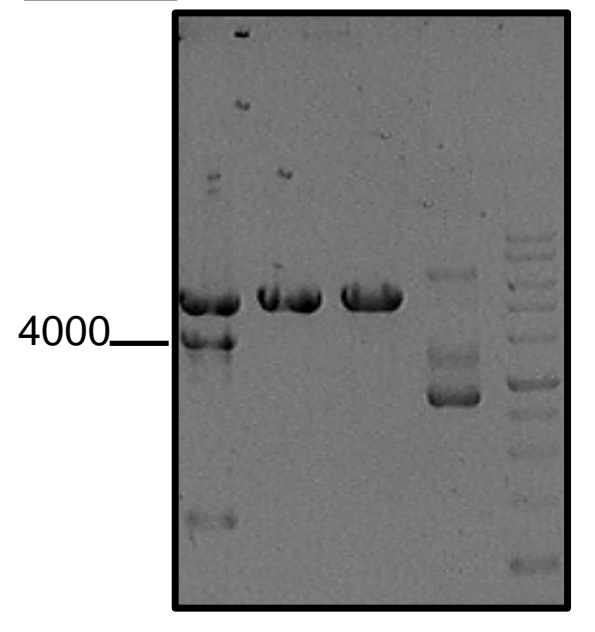

Carril : $1 \quad 2 \quad 3 \quad 4 \quad 5$

c) $\mathrm{PM}(\mathrm{pb})$

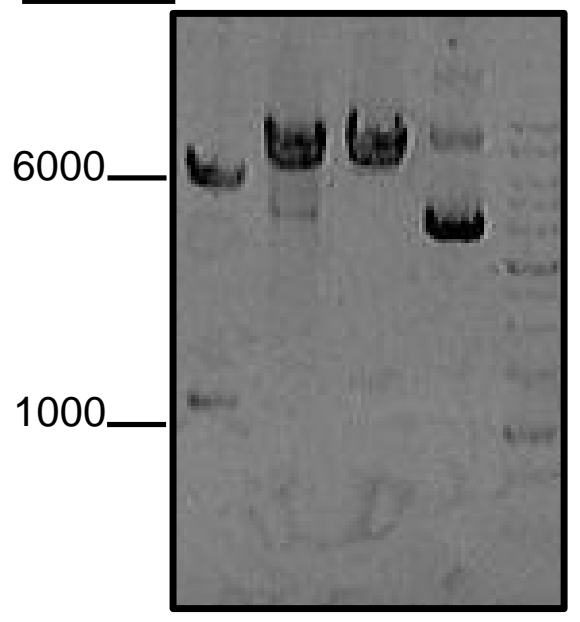

Carril : $1 \quad 2 \quad 3 \quad 4 \quad 5$ b) $\mathrm{PM}(\mathrm{pb})$

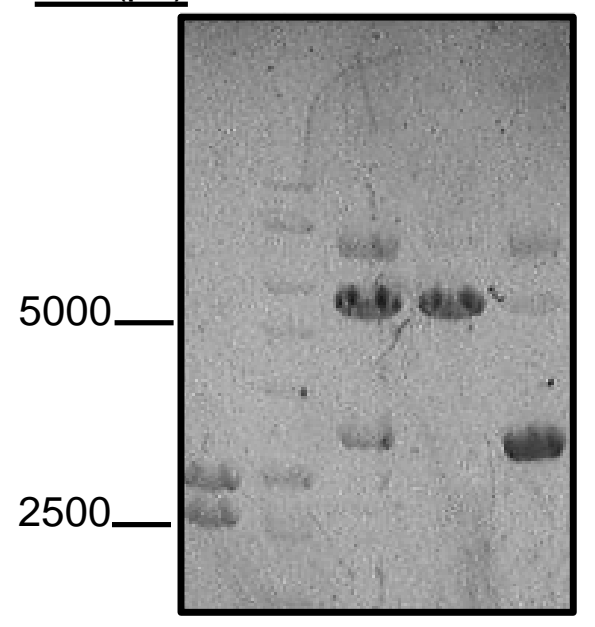

Carril : $1 \quad 2 \quad 3 \quad 4 \quad 5$

d) $\mathrm{PM}(\mathrm{pb})$

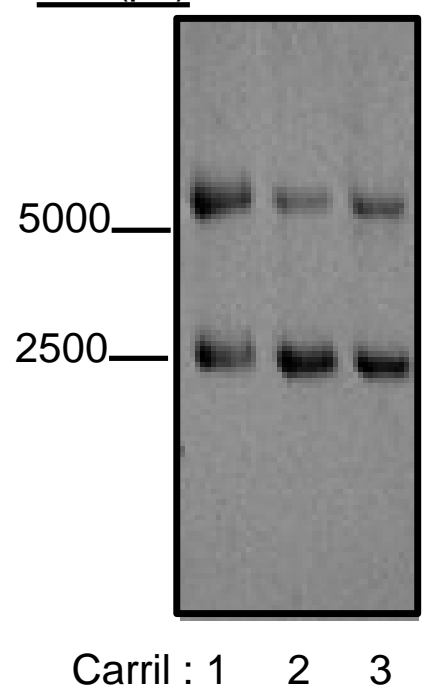

Figura 5. Los plásmidos PPIX y pPX están ensamblados correctamente. Se muestran los geles en colores invertidos para mejorar su visualización. a) Digestión de pPI. Carril 1: digestión doble con Notl y Xmal. Se genera un vector linearizado de $4 \mathrm{~kb}$; carril 2: control positivo con Notl; carril 3: control positivo con Xmal; carril 4: control negativo (sin digerir); carril 5: Marcador de peso molecular $(1 \mathrm{~kb})$ de Biotools. b) Digestión de pPVIII. Carril 1: digestión doble con Notl y Xmal- Se genera un fragmento de $2.5 \mathrm{~kb}$; carril 2: Marcador de peso molecular (1 kb) de Biotools; carril 3: control positivo con Notl; carril 4: control positivo con Xmal; carril 5: control negativo (sin digerir). c) Digestión de pPIX. Carril 1: digestión doble con Sall y Xmal; se genera una banda de $5.4 \mathrm{~kb}$ del vector y un fragmento escindido correspondiente al gen de resistencia a la neomicina; carril 2: Marcador de peso molecular (1 kb) de Biotools; carril 3: control positivo con Sall; carril 4: control positivo con Xmal; carril 5: control negativo (sin digerir). d) Confirmación de la ligación de pPX. Carril 1: negativo para Sall; carril 2: negativo para Xmal; carril 3: control negativo (sin digerir). 
a)

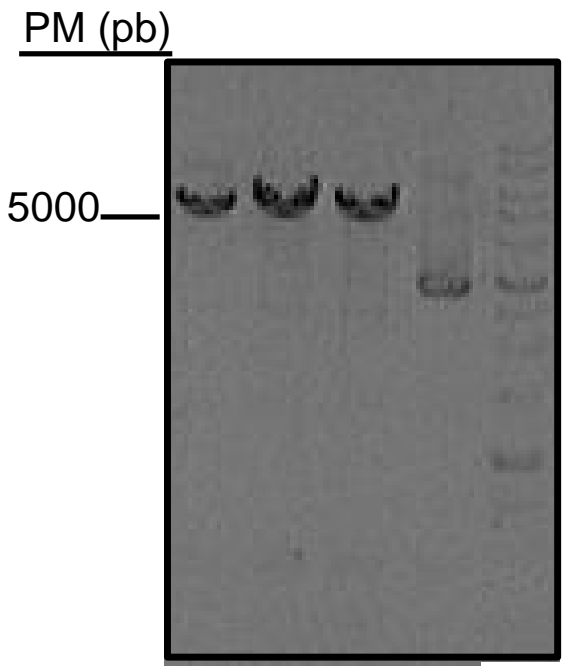

Carril : $1 \quad 2 \quad 3 \quad 4 \quad 5$ b) $\mathrm{PM}(\mathrm{pb})$

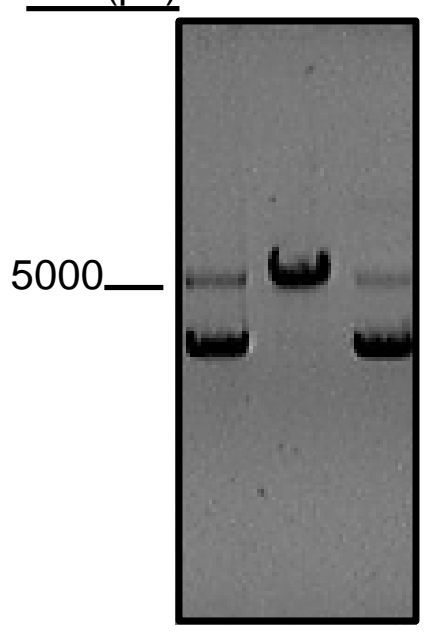

Carril : $1 \quad 2 \quad 3$

c)

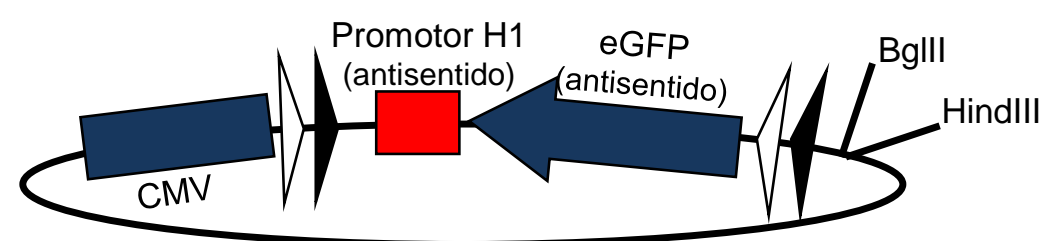

d)

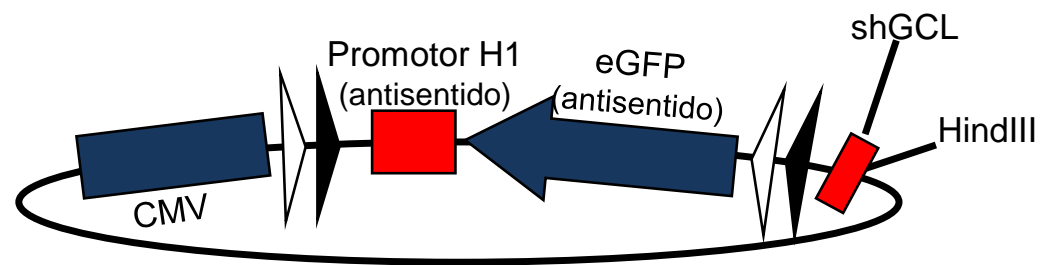

Figure 6. El plásmido pPXI está ensamblado correctamente. Se muestran los geles en colores invertidos para mejorar su visualización. a) Digestión de pPX. Carril 1: digestión doble con Bglll y Hindlll. Se genera un vector de $5.4 \mathrm{~kb}$; carril 2: Marcador de peso molecular (1 kb) de Biotools; carril 3: control positivo con Bglll; carril 4: control positivo con Hindlll; carril 5: cotrol negativo (sin digerir). b) Confirmación de la ligación de pPXI. Carril 1: negativo para Bglll; carril 2: tamaño correcto para la digestión con Hindlll; carril 3: control negativo (sin digerir). c) Representación esquemática del plásmido $\mathrm{pPX}$. El promotor CMV está situado en la orientación sentido, mientras que el promotor H1 y la eGFP están situados en la orientación anti-sentido; Lox 2272 (puntas de flecha blancas) y loxP (puntas de flecha negras) están situados tanto en las orientaciones sentido y anti-sentido. Nótense los sitios de restricción únicos de Blglll y Hindlll. d) Representación esquemática del plásmido pPXI. Este plásmido contiene los mismos elementos que c, excepto que el shRNA contra la subunidad catalítica de la GCL ha eliminado el sitio de restricción para Bglll (representado en el plásmido $\mathrm{pX)}$ tras la ligación. 
a)

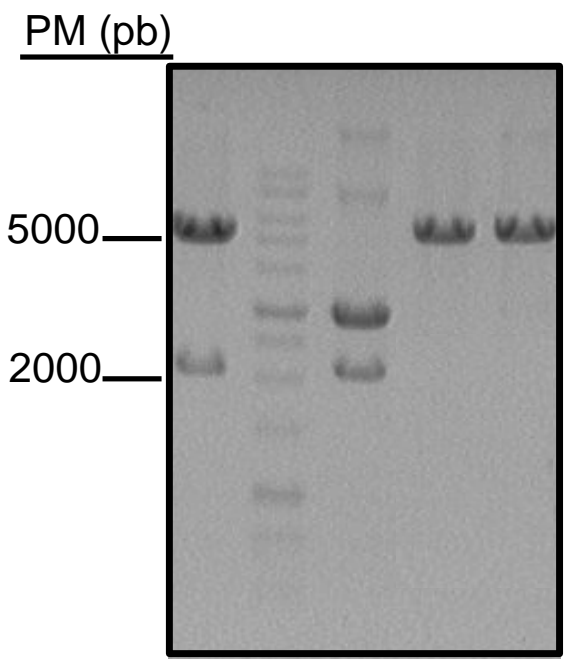

Carril : $1 \quad 2 \quad 3 \quad 4 \quad 5$

d)

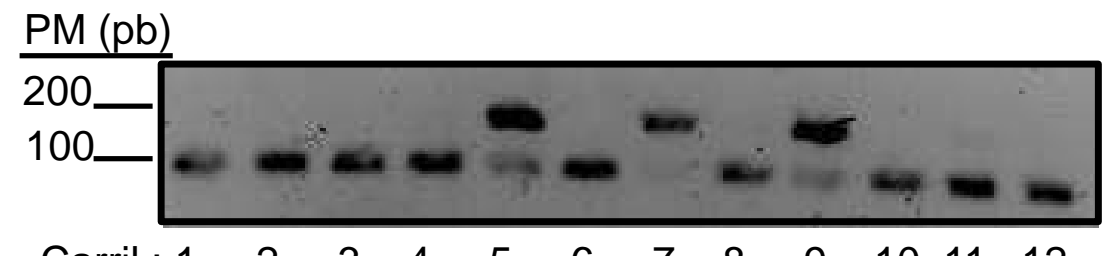

b) $\mathrm{PM}(\mathrm{pb})$

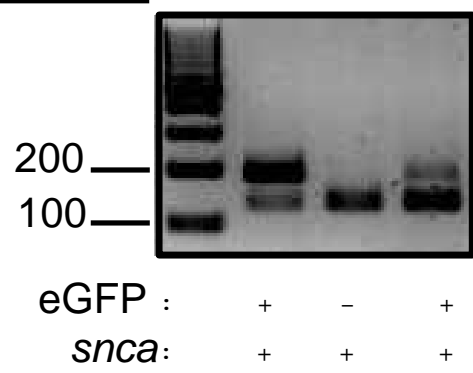

c)

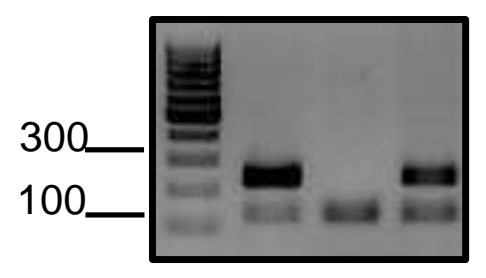

Cre:

snca:

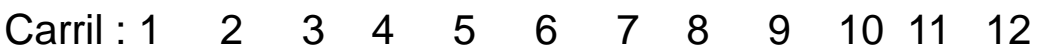

Figura 7. La microinyección de la construcción shGCL floxed derivada del plásmido $\mathrm{pXI}$ genera satisfactoriamente ratones fundadores $s h G C L^{\text {floxed }}$. Se muestran los geles en colores invertidos para mejorar su visualización. a) La construcción shGCL floxed es escindida correctamente del plásmido PPXI para ser microinyectada. Carril 1: control negativo (sin digerir); Carril 2: Marcador de peso molecular (1 kb) de Biotools; carril 3: digestión doble con Aflll y Asel que muestra el fragmento de $~ 2200$ bp utilizado para las microinyecciones; Carril 4: control positivo con Aflll; carril 5: control positivo con Asel. b) EL transgén shGCL floxed está genotipado correctamente. Análisis por PCR del transgén $S h G C L^{\text {floxed }}$, utilizando primers para amplificar la eGFP (generando una banda de 200 bp) y snca (generando una banda de 150 bp; utilizada como control interno). c) El transgén CamKIll-Cre está genotipado correctamente. Análisis por PCR del transgén CamKIl $\alpha$-Cre utilizando primers para amplificar un fragmento de Cre (generando una banda de $~ 270 \mathrm{bp}$ ) y snca (generando una banda de $150 \mathrm{bp}$; utilizada como control interno). d) Generación satisfactoria de los fundadores shGCL ${ }^{\text {floxed. }}$. Análisis por PCR del transgén shGCL floxed utilizando primers para amplificar la eGFP (generando una banda de 200 bp) y snca (generando una banda de 150 bp; utilizada como control interno). Sólo los carriles 5,7 y 9 corresponden a fundadores positivos. 


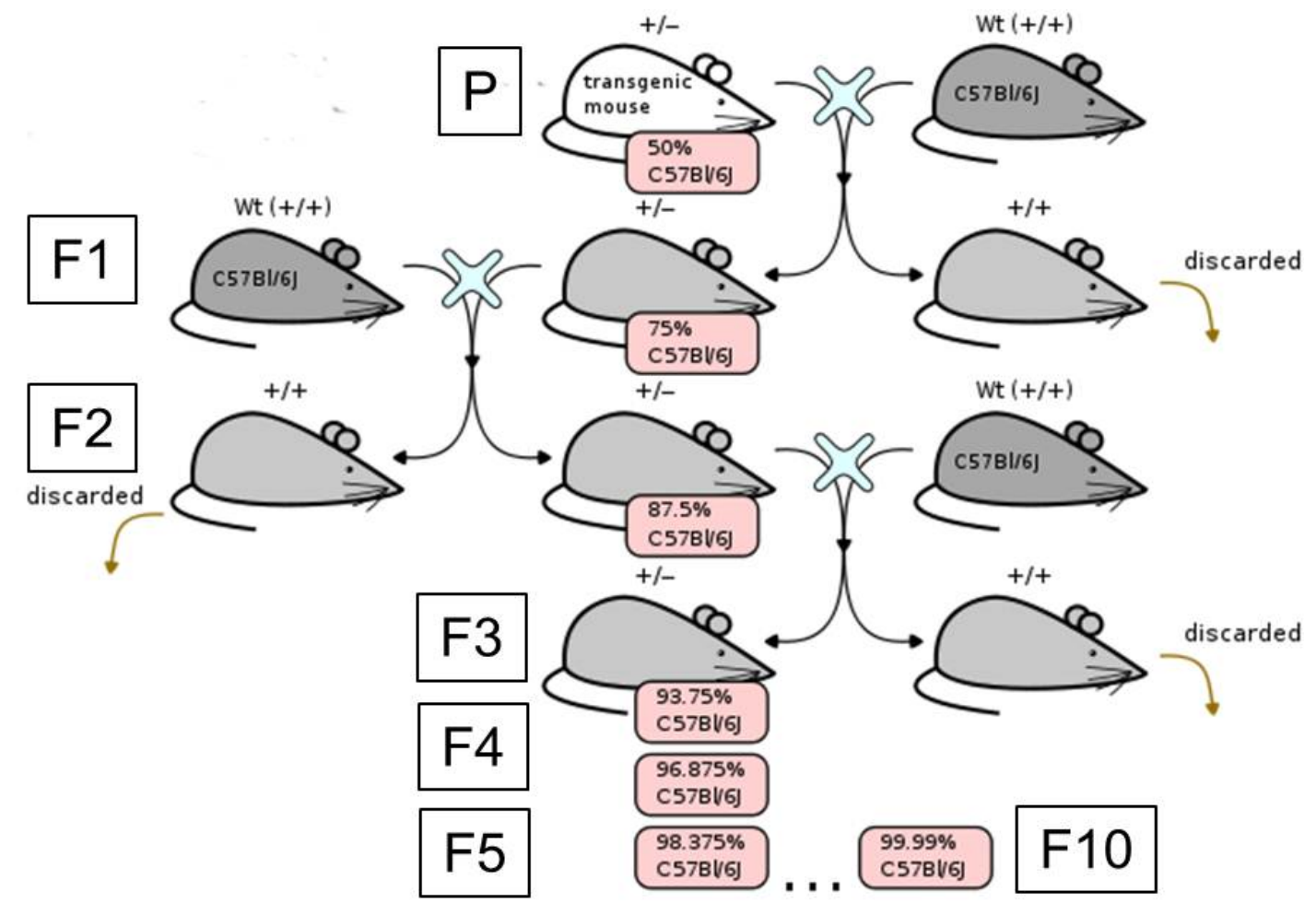

Esquema 3. Retrocruzamiento de los fundadores $s h G C L^{\text {floxed. }}$. Los fundadores parentales (P) shGCL floxed hemicigotos para el transgén [shGCL(+/-)] fueron retrocruzados con ratones silvestres C57BI/6J. Los ratones de la progenie que no portaban la construccion fueron descartados. Los portadores positivos fueron retrocruzados sucesivamente para incrementar la homogeneidad genómica de su cepa (C57BI/6J). Nótense los porcentajes de homogeneidad en cada generación. El número de cada generación se denota como F1, F2, ... Los animales fueron considerados congénicos en la décima generación (F10). 
a)

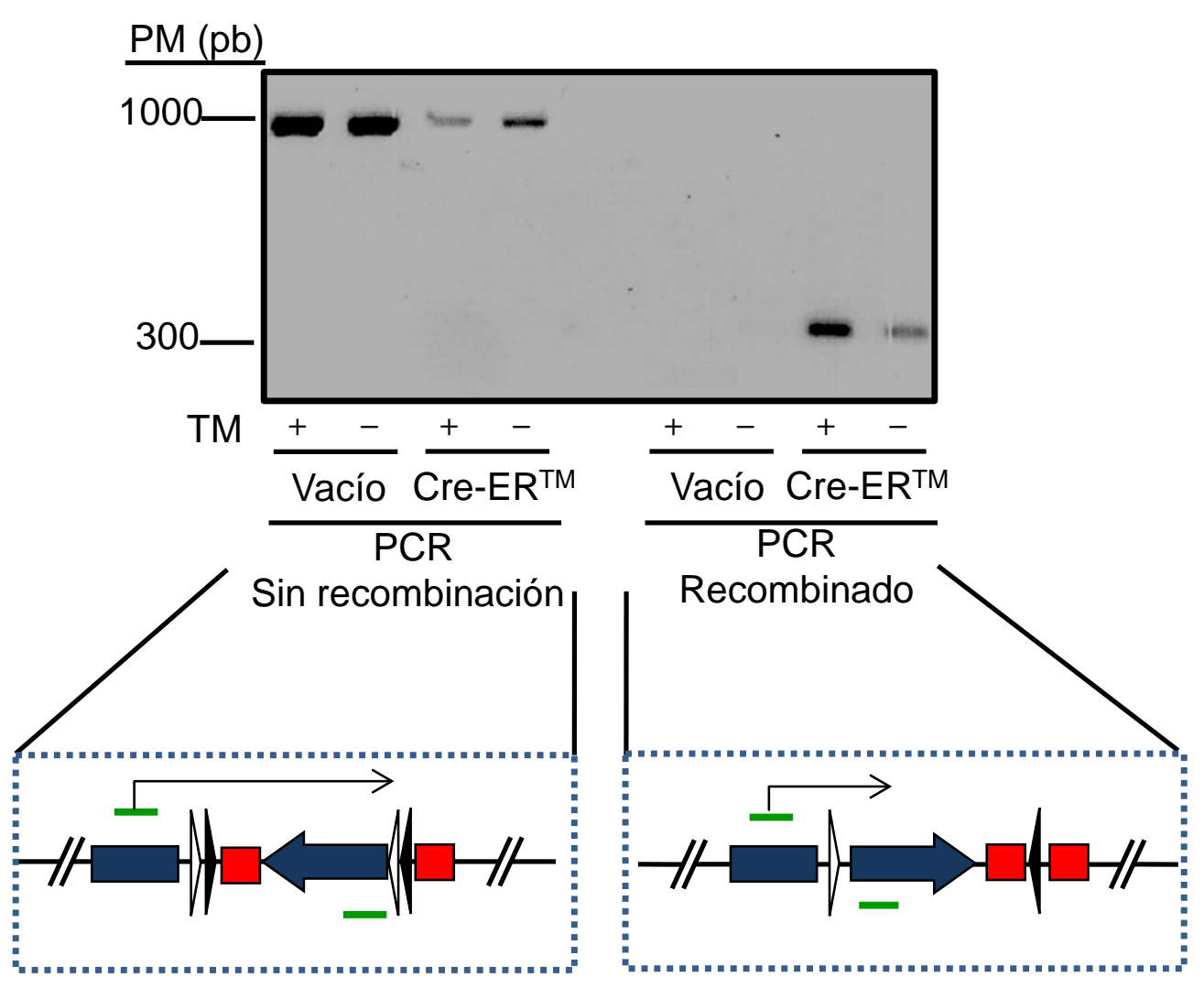

b)

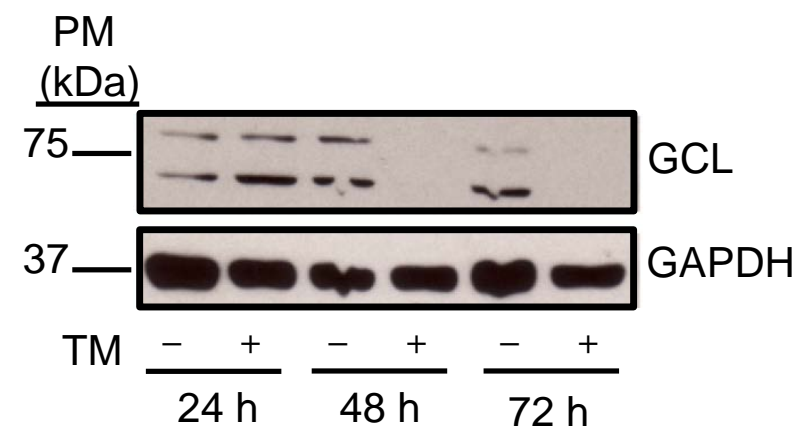

Figura 8. La recombinación del DNA y la disminución de la síntesis de GCL se consiguen en MEFs shGCL floxed tras la expresión del cDNA de Cre. MEFs provenientes de ratones $S h G C L^{\text {floxed }}$ fueron transfectados con pCMV-CreER ${ }^{\mathrm{TM}} \mathrm{o}$ un vector vacío. Seis horas tras la transfección, se añadió 4-hidroxi-tamoxifeno (TM; $1 \mu \mathrm{M}) 0$ vehículo. a) EI DNA se recombina satisfactoriamente. EI DNA total aislado de MEFs 24 horas tras la adición de TM fue sometido a análisis por PCR para confirmar la recombinación. Se observaron bandas robustas ( 1,000 bp) correspondientes a una ausencia de recombinación en MEFs transfectados con el vector vacío, mientras que se observaron bandas más débiles en células transfectadas con CreER ${ }^{\mathrm{TM}}$; las células transfectadas con CreER ${ }^{\mathrm{TM}}$ y tratadas con TM mostaron las bandas más débiles de todas. Una banda robusta correspondiente a un proceso de recombinación positivo ( 300 bp) fue observada en las células transfectadas con CreER ${ }^{\mathrm{TM}}$ y tratadas con TM, mientras que una banda muy débil se observó en las células trasnsfectadas con CreER ${ }^{\mathrm{TM}}$ y tratadas con vehículo. Nótese la localización de los oligonucleotidos (líneas verdes) en la construcción no recominada o recombinada. b) La síntesis proteica de la GCL es disminuida correctamente. Extractos de proteínas totales sometidos a western blot revelan la disminución de la GCL a las 48 h y 72 h en células transfectadas con CreER ${ }^{\mathrm{TM}}$ y tratadas con TM. 

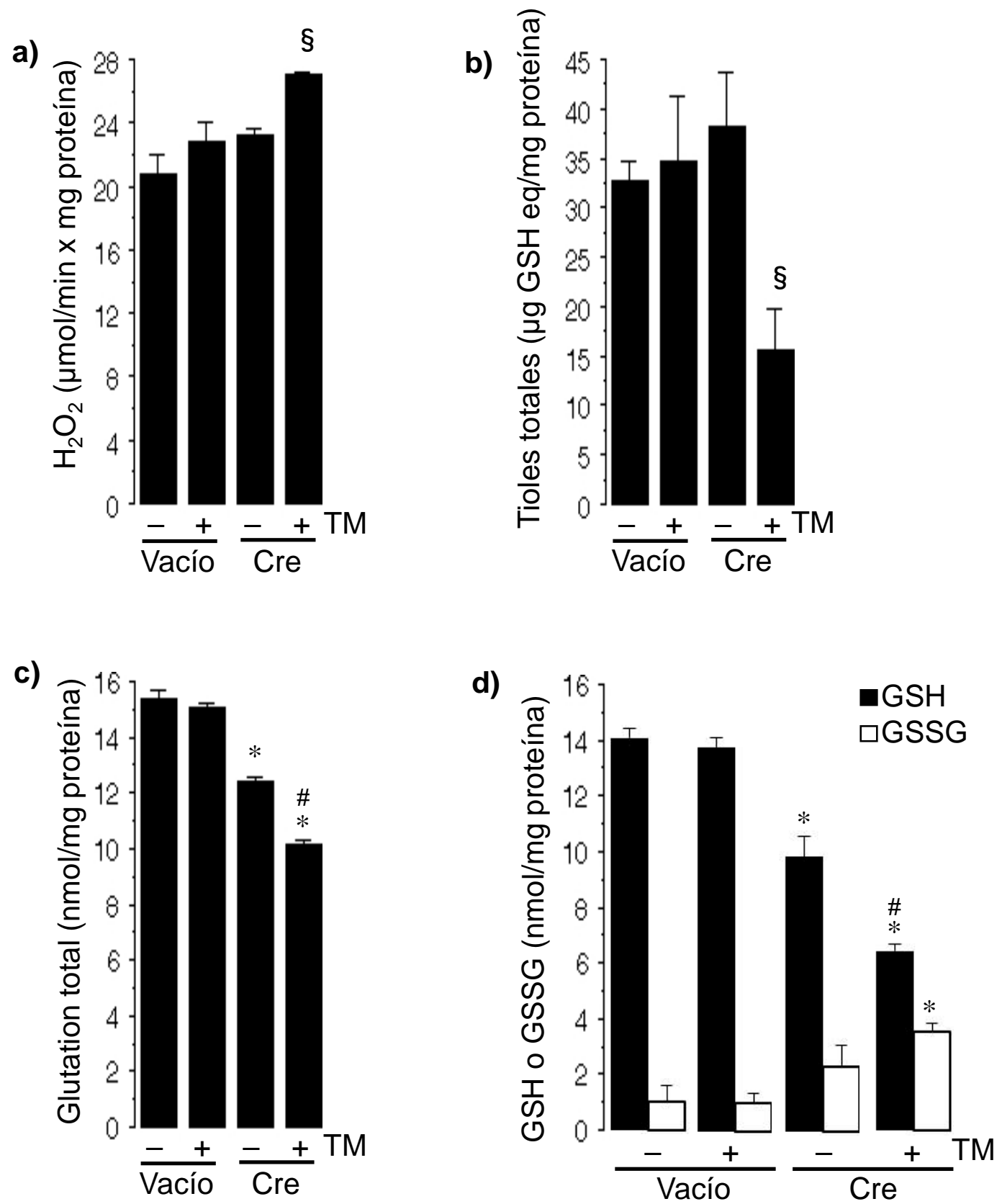

Figura 9. MEFs derivados de shGCL floxed muestran señales de estrés oxidativo tras la recombinación mediada por Cre. MEFs derivados de ratones $s h G C L^{\text {floxed }}$ fueron transfectados con $\mathrm{pCMV}$-CreER ${ }^{\mathrm{TM}}$ o con un vector vacío. Seis horas después, se añadió 4-hidroxi-tamoxifeno (TM; $1 \mu \mathrm{M})$ o vehículo. Las células fueron analizadas $24 \mathrm{~h}$ después. a) Detección de la tasa de producción de $\mathrm{H}_{2} \mathrm{O}_{2}$. EL tratamiento con TM no tuvo efecto en detección de la tasa de producción de $\mathrm{H}_{2} \mathrm{O}_{2}$ a menos que las células hubiesen sido transfectadas previamente con $\mathrm{CreER}^{\mathrm{TM}}$. b) Concentración de tioles totales. El tratamiento con TM no tuvo efecto en la concentración de tioles totales a menos que las células hubiesen sido transfectadas previamente con CreER ${ }^{\mathrm{TM}}$. c) Concentración de glutation total. La transfección con CreER ${ }^{T M}$ disminuyó levemente la concentración de glutation total; el TM diminuyó aún más la concentración de glutation total en las células transfectadas con CreER ${ }^{\mathrm{TM}}$, pero no en las transfectadas con un vector vacío. d) Concentraciones de glutation reducido (GSH) y oxidado (GSSG). La transfección con CreER ${ }^{T M}$ disminuyó ligeramente la concentración de $\mathrm{GSH}$, que disminuyó aún más en las células tratadas con TM; tambiñen se incrementó las concentraciones de GSSG en las células transfectadas con CreER ${ }^{\mathrm{TM}}$, pero no en las transfectadas con un vector vacío. $\S p \leq 0.05$ vs no TM; ${ }^{*} \mathrm{p} \leq 0.05$ vs empty; $\# p \leq 0.05$ vs no TM (ANOVA; $n=3$ ). 


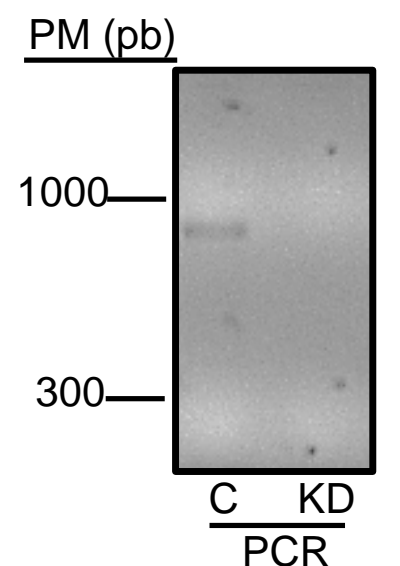

No recombinado

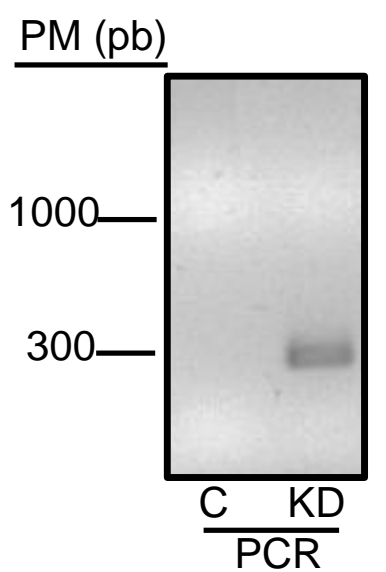

Recombinado

Figura 10. El ratón shGCL floxed presenta recombinación en el hipocampo tras ser cruzado con el ratón CamKIll-Cre in vivo. Los cerebros fueron extraídos de ratones CamKIl $\alpha$-Cre/shGCL floxed de 40 semanas, su hipocampo fue diseccionado y se extrajo DNA para su posterior genotipado. Los genotipos utilizados fueron CamKIl $\alpha-$ Cre $(+/-) /$ shGCL(-/-) (definido como control, C) y CamKIl $\alpha-C r e(+/-) /$ shGCL(+/-) (definido como knockdown; KD). Los geles se muestran en colores invertidos para mejorar su visualización. Tal como se muestra en el panel izquierdo, la banda correspondiente a la ausencia de recombinación $(\sim 1,000 \mathrm{pb})$ fue detectada en ratones $C$ pero no $\mathrm{KD}$. Como se muestra en el panel de la derecha, la banda correspondiente tras la recombinación ( $\sim 300 \mathrm{pb}$ ) se observa en los ratones KD pero no en los C. Los primers utilizados se muestran en la figura 8.a. 


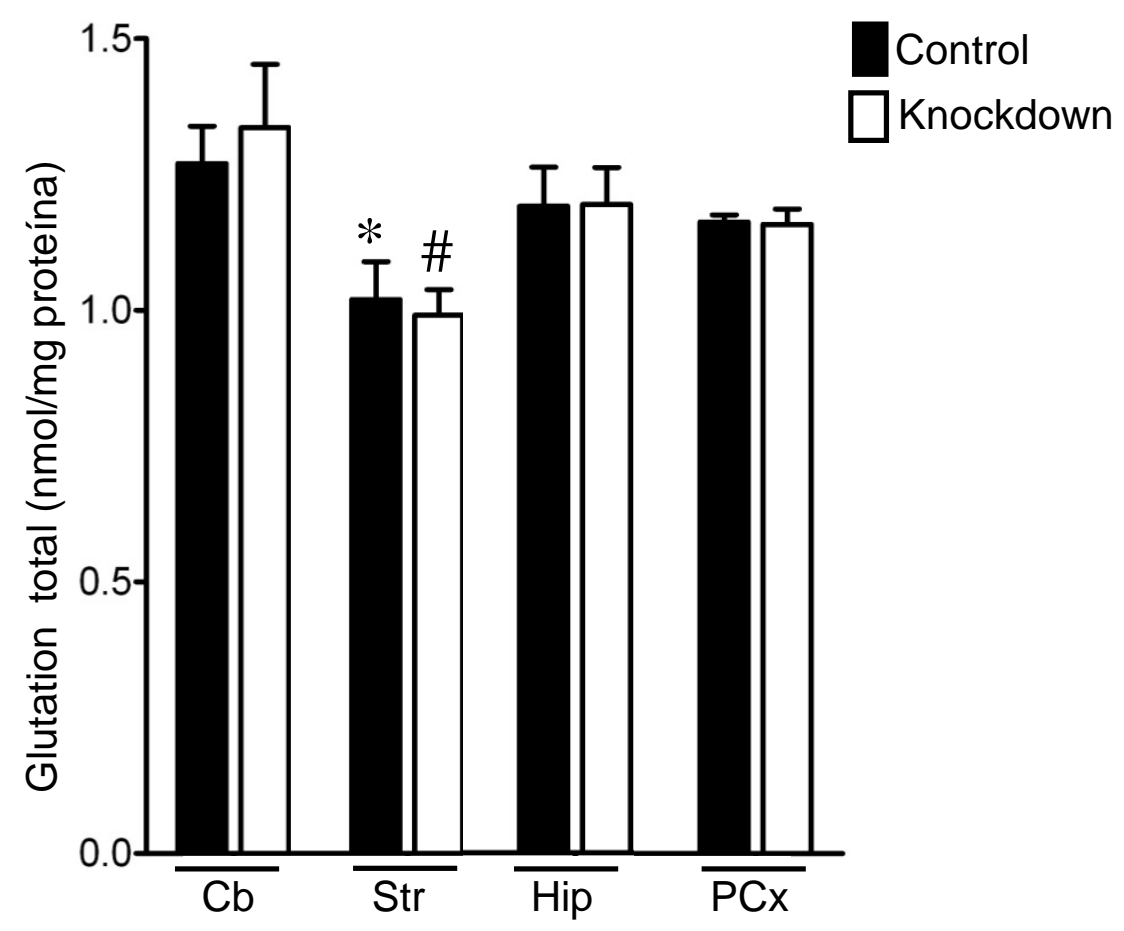

Figura 11. No se detecta disminución de la concentración de glutation total en tejidos cerebrales de los ratones CamKIll $\alpha$-Cre/shGCL floxed in vivo. Los cerebros fueron extraídos de ratones CamKIl $\alpha-\mathrm{Cre}(+/-) / \operatorname{shGCL}(-/-)$ (control) y CamKIl $\alpha-C r e(+/-) / s h G C L(+/-)$ (knockdown) de 40 semanas y se diseccionó su cerebelo (Cb), striatum (Str), hipocampo (Hip) y cortex prefrontal (PCx). En las muestras -que contienen una mezcla de todos los tipos de células cerebrales- se procedió a determinar la concentración de glutation total. Como se muestra, no se encontraron diferencias en la concentración de glutation total entre los grupos controles y los knockdown en ninguna de las áreas utilizadas. Curiosamente, la concentración de glutation total se encontró significativamente menor en el striatum de los ratones, sin tener en cuenta el genotipo, cuando se comparaba con el resto de las regiones cerebrales analizadas. ${ }^{*} p \leq 0,05$ vs control en otras áreas cerebrales; \# $\mathrm{p} \leq 0,05$ vs knockdown en otras áreas cerebrales (ANOVA; $n=3$ ). 
a) Hembras

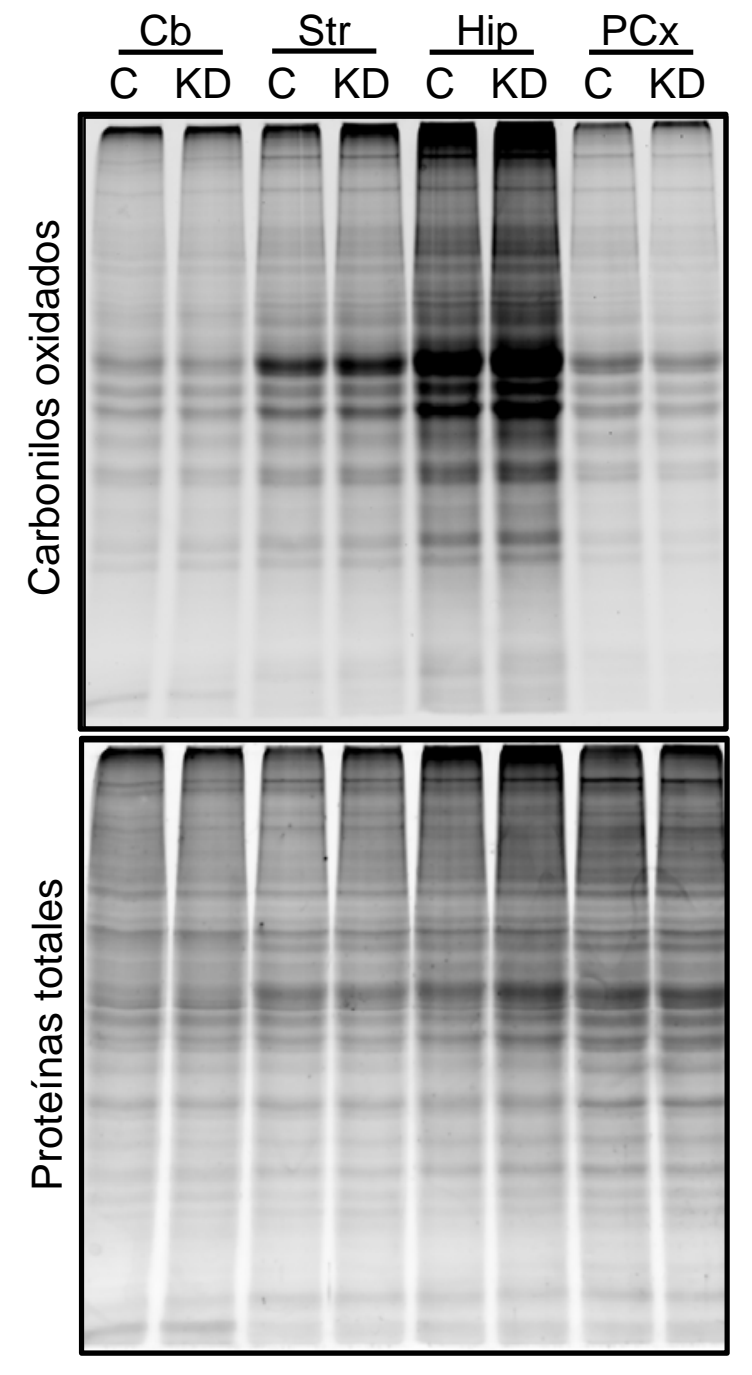

b) Machos

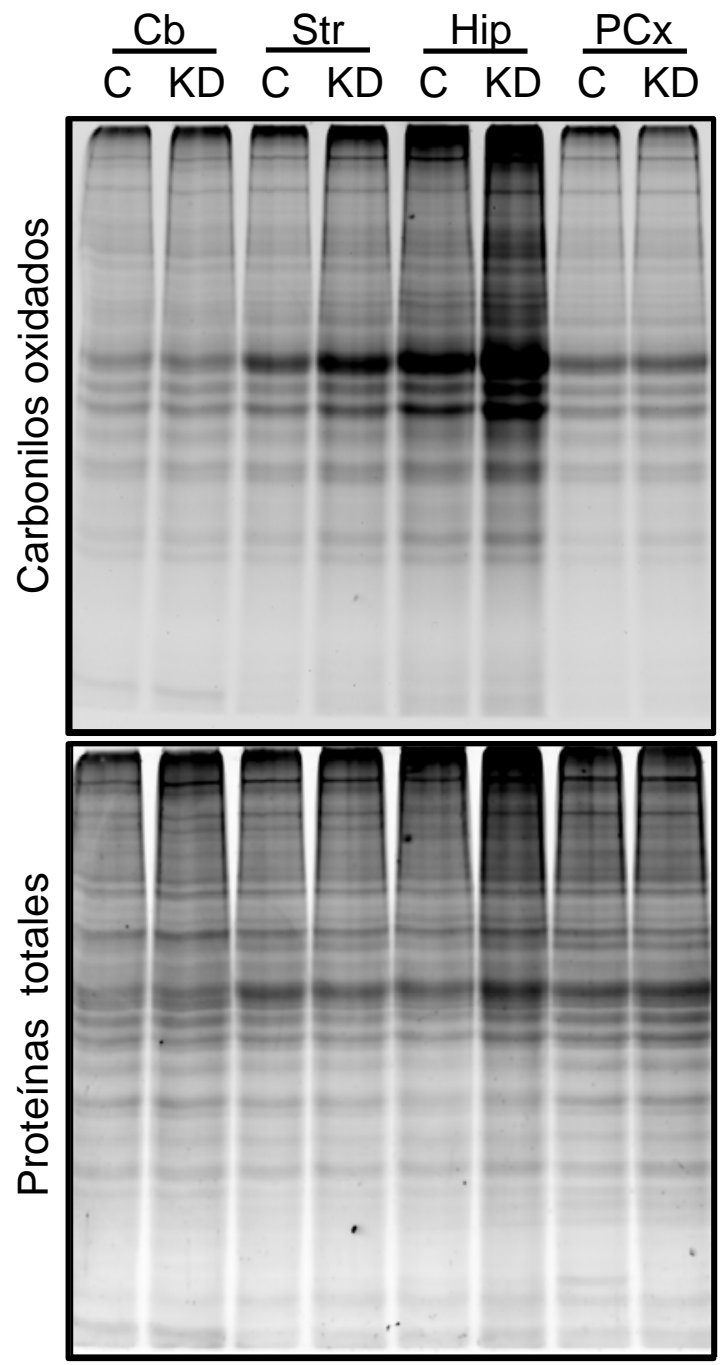

Figura 12. Los ratones CamKIl $\alpha$-Cre/shGCL floxed muestran un incremento de los carbonilos oxidados in vivo. Los cerebros fueron extraídos de ratones CamKIl $\alpha-\mathrm{Cre}(+/-) / \mathrm{shGCL}(-/-)$ (control; C) y CamKIl $\alpha-\mathrm{Cre}(+/-) / \mathrm{shGCL}(+/-)$ (knockdown; KD) de 40 semanas y se diseccionó su cerebelo $(\mathrm{Cb})$, striatum (Str), hipocampo (Hip) y cortex prefrontal (PCx). Las muestras fueron procesadas para detectar proteínas con carbonilos oxidados (panel superior) y abundancia de proteínas totales (panel inferior) en hembras (a) y machos (b). Como se muestra en a, el hipocampo las hembras knockdown presenta mayores valores de carbonilos oxidados que en los controles. En los machos, (b) tanto en el hipocampo como en el striatum se encuentran niveles mayores de carbonilos oxidados respecto a los controles. 

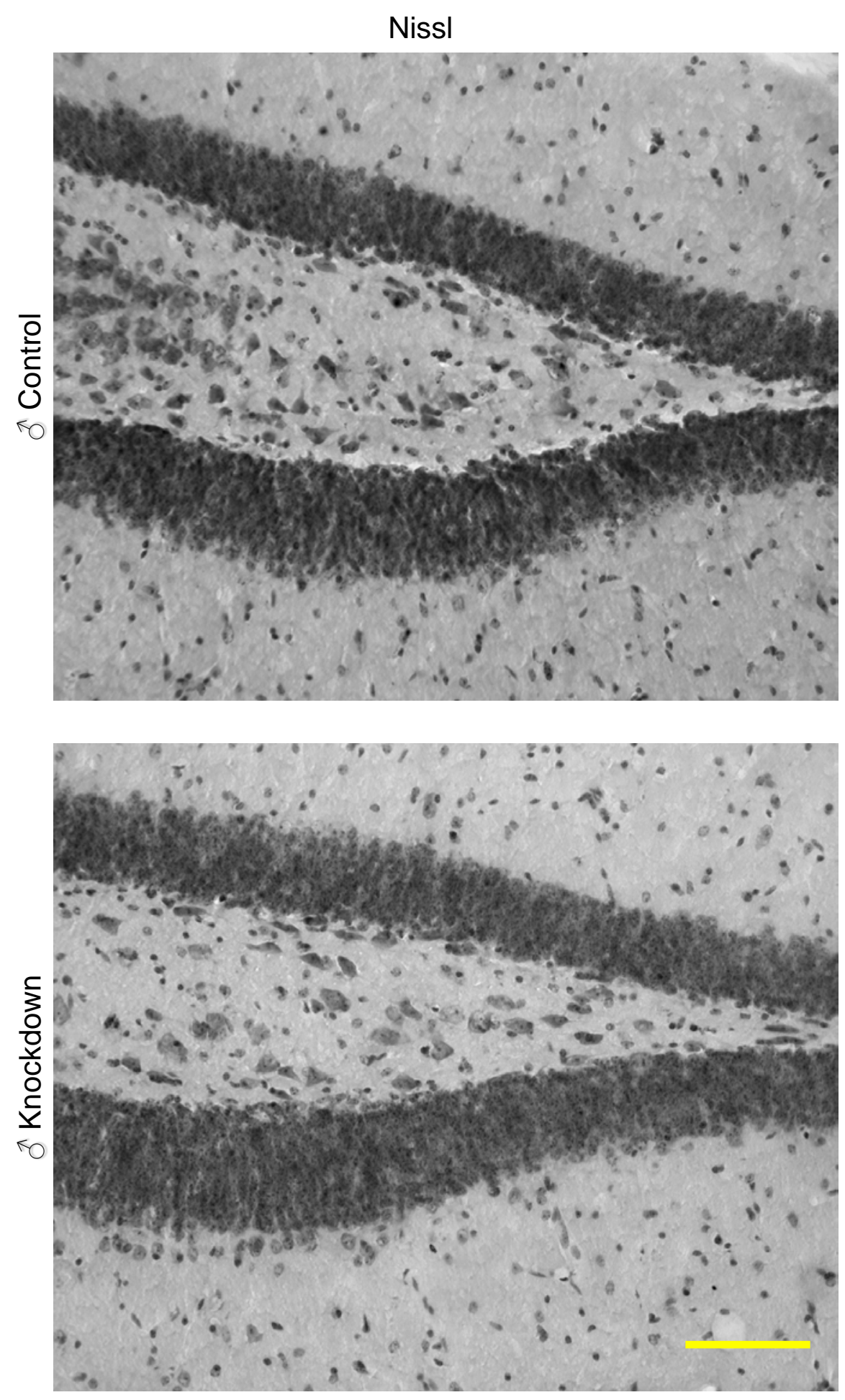

Figure 13. La tinción de Nissl no muestra cambios morfológicos o estructurales en el hipocampo de ratones CamKIla-Cre/shGCL floxed. Las microfotografías muestran zonas de hipocampo de tejido cerebral de machos CamKIl $\alpha-$ Cre $(+/-) /$ shGCL(-/-) (control) y CamKIl $\alpha-C r e(+/-) /$ shGCL(+/-) (knockdown) de cuarenta semanas. Tal como se muestra, no se aprecian diferencias estructurales o morfológicas notables entre los ratones control y knockdown. (Barra de escala: $100 \mu \mathrm{m}$ ). 


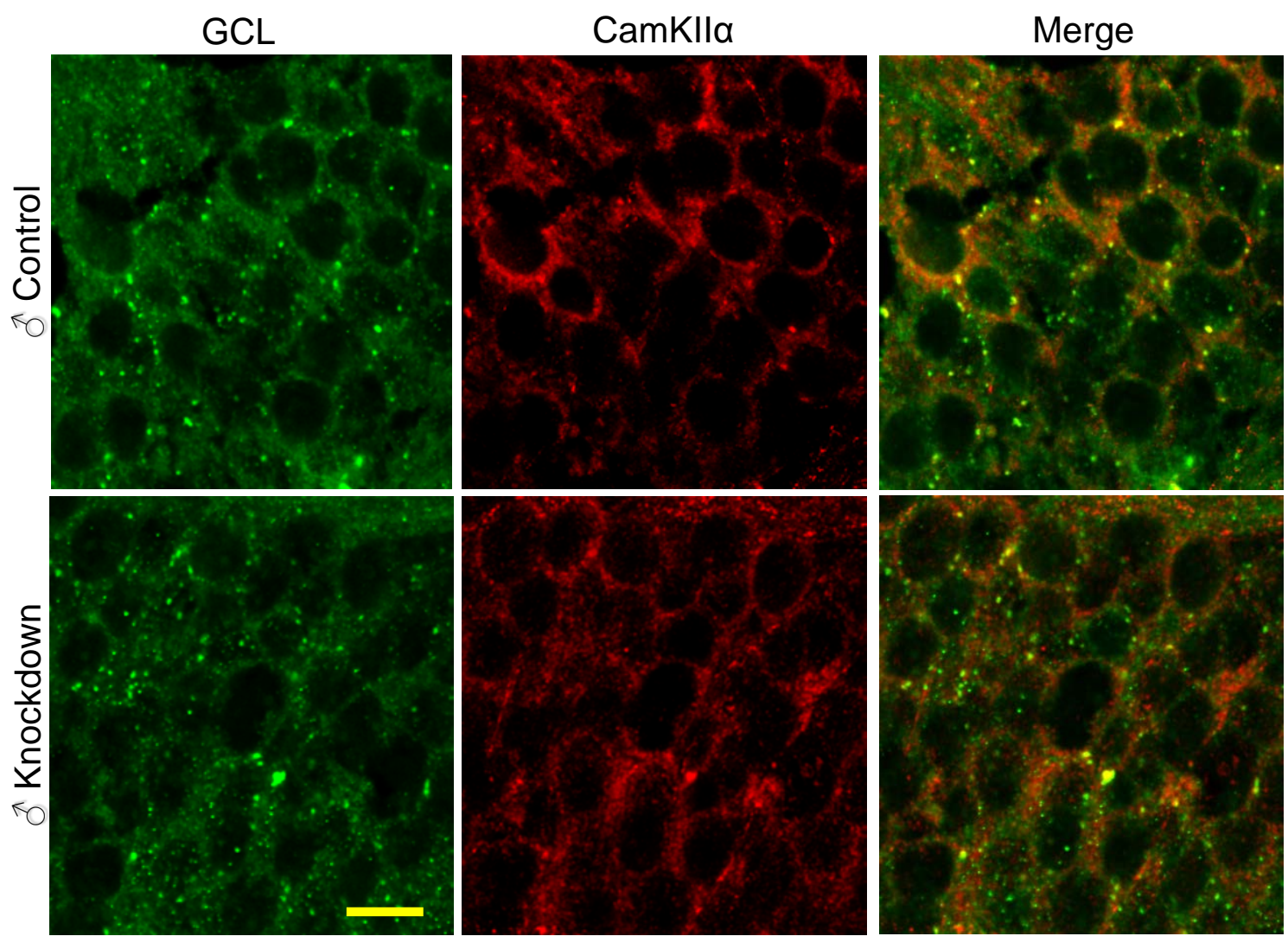

Figura 14. La baja concentración de GCL en el cerebro dificulta la detección inmunohistoquímica en los ratones CamKIl $\alpha$-Cre/shGCL floxed knockdown. Imágenes confocales de células del hipocampo de tejido cerebral de ratones machos CamKIl $\alpha-C r e(+/-) /$ shGCL(-/-) (control) y CamKIl $\alpha-C r e(+/-) / s h G C L(+/-)$ (knockdown) de 40 semanas. Como se muestra, no existían diferencias detectables en las tinciones para detectar GCL entre los ratones control (imágenes superiores) y knockdown. Como se discute en el texto, es posible debido a los bajos niveles detectables de GCL en el cerebro (Godoy et al., 2011). Nótense los puntos más densos de GCL en las imágenes, que podrían representar una localización vesicular o una agregación proteica. No se apreciaron diferencias en el marcaje para Camkll $\alpha$ entre ambos grupos de animales. (Barra de escala: $12 \mu \mathrm{m}$. La adquisición secuencial de las imágees no fue necesaria). 


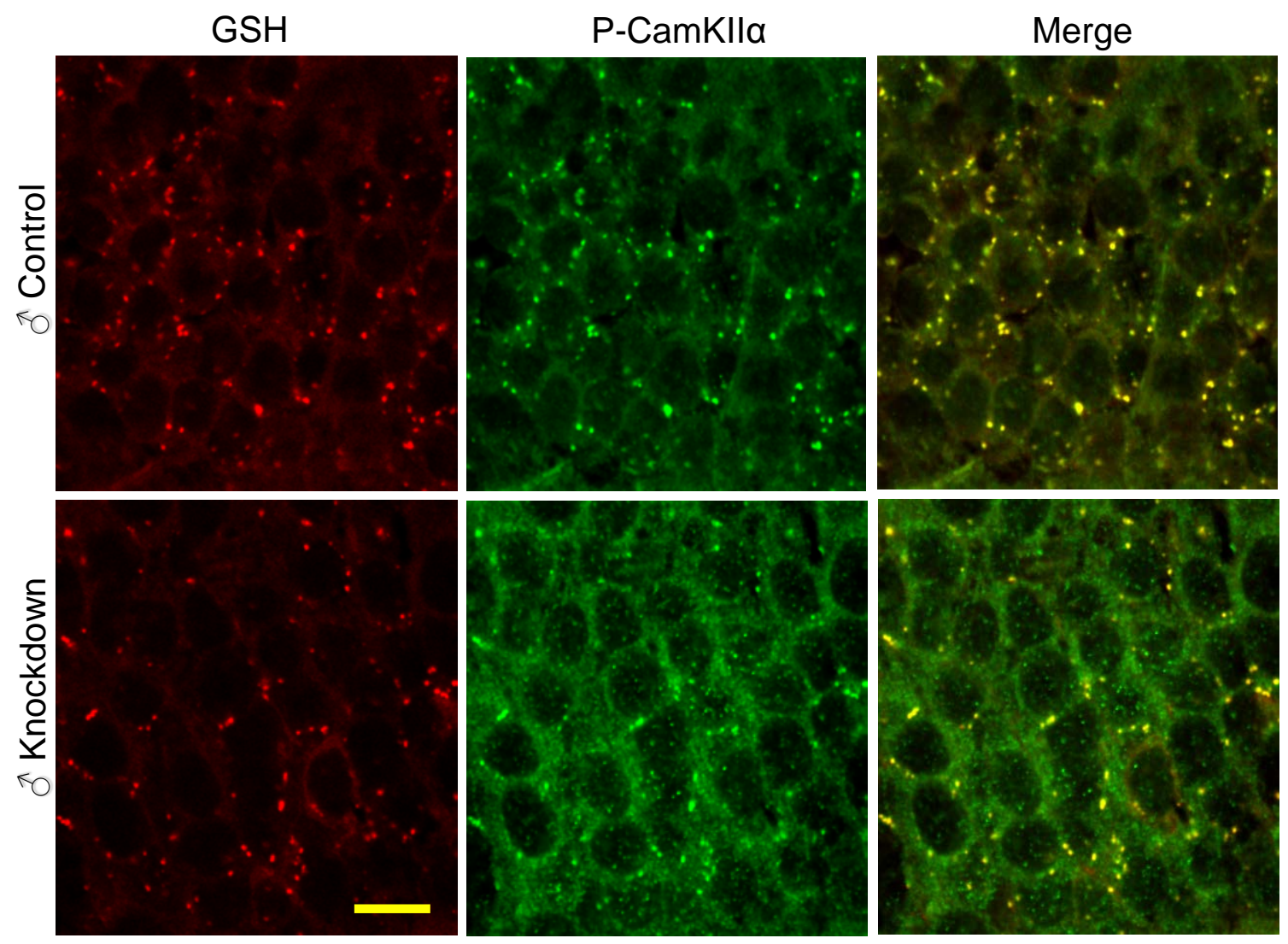

Figura 15. Las proteínas glutationiladas disminuyen y la forma fosforilada

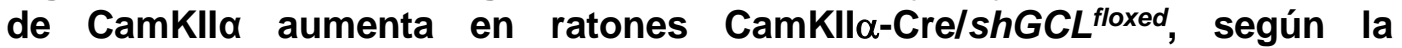
inmunohistoquimica. Imágenes confocales de células del hipocampo de tejido cerebral de ratones machos CamKIl $\alpha-\mathrm{Cre}(+/-) / \mathrm{shGCL}(-/-)$ (control) y CamKIl $\alpha-$ Cre(+/-)/shGCL(+/-) (knockdown) de 40 semanas. La abundancia de proteínas glutationiladas es menor en los ratones knockdown (panel inferior) en comparación a los controles (panel superior). El marcaje para la fosfo-CamKIla (P-CamKIla) es mayor en los ratones knockdown (panel inferior) en comparación con los controles (panel superior). Nótense los puntos más densos presentes en el tejido, que podrían revelar tanto una localización vesicular como agregados proteicos, y cómo esos puntos están enmascarados en el marcaje para PCamKIla (posiblemente debido a la alta intensidad del marcaje). (Barra de escala: $12 \mu \mathrm{m}$. Los canales de las imágenes de fluorescencia fueron tomados secuencialmente). 

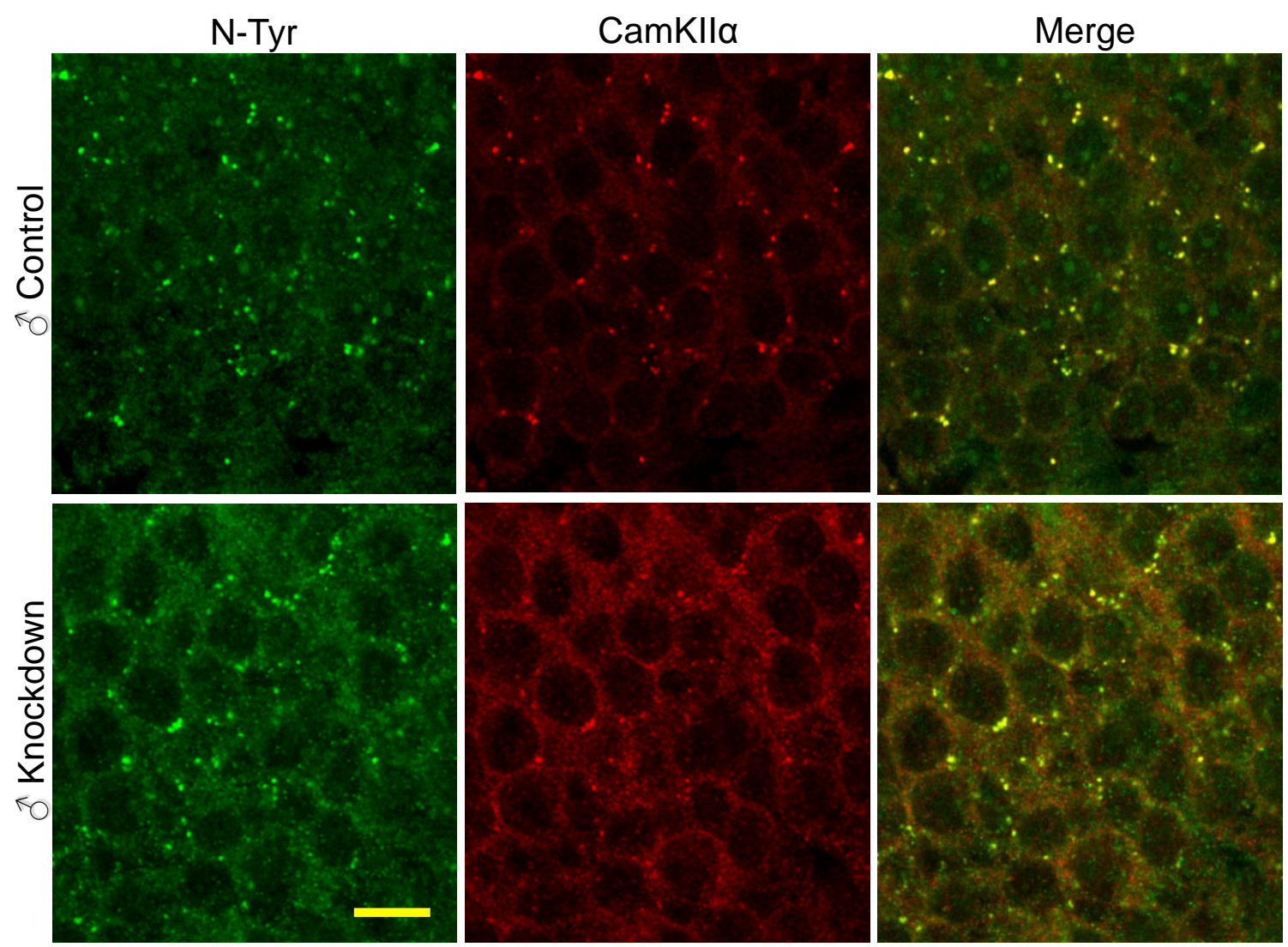

Figura 16. Incremento en las proteínas nitradas en el ratón CamKIl $\alpha$ CrelshGCL floxed, según la inmunohistoquímica. Imágenes confocales de células del hipocampo de tejido cerebral de ratones macho CamKIl $\alpha-\mathrm{Cre}(+/-$ )/shGCL(-/-) (control) y CamKIl $\alpha-C r e(+/-) /$ shGCL(+/-) (knockdown) de 40 semanas. La abundancia de 3-nitrotirosina en las proteínas (proteínas nitradas) es mayor en los ratones knockdown (panel inferior) en comparación con los controles (panel superior). El marcaje para CamKIla es superior en los ratones knockdown (panel inferior) en comparación a los controles (panel superior). Nótense los puntos más densos presentes en el tejido, que podrían revelar tanto una localización vesicular como agregados proteicos, y cómo esos puntos están enmascarados en el marcaje para CamKlla (posiblemente debido a la alta intensidad del marcaje. (Barra de escala: $12 \mu \mathrm{m}$. Los canales de las imágenes de fluorescencia fueron tomados secuencialmente). 


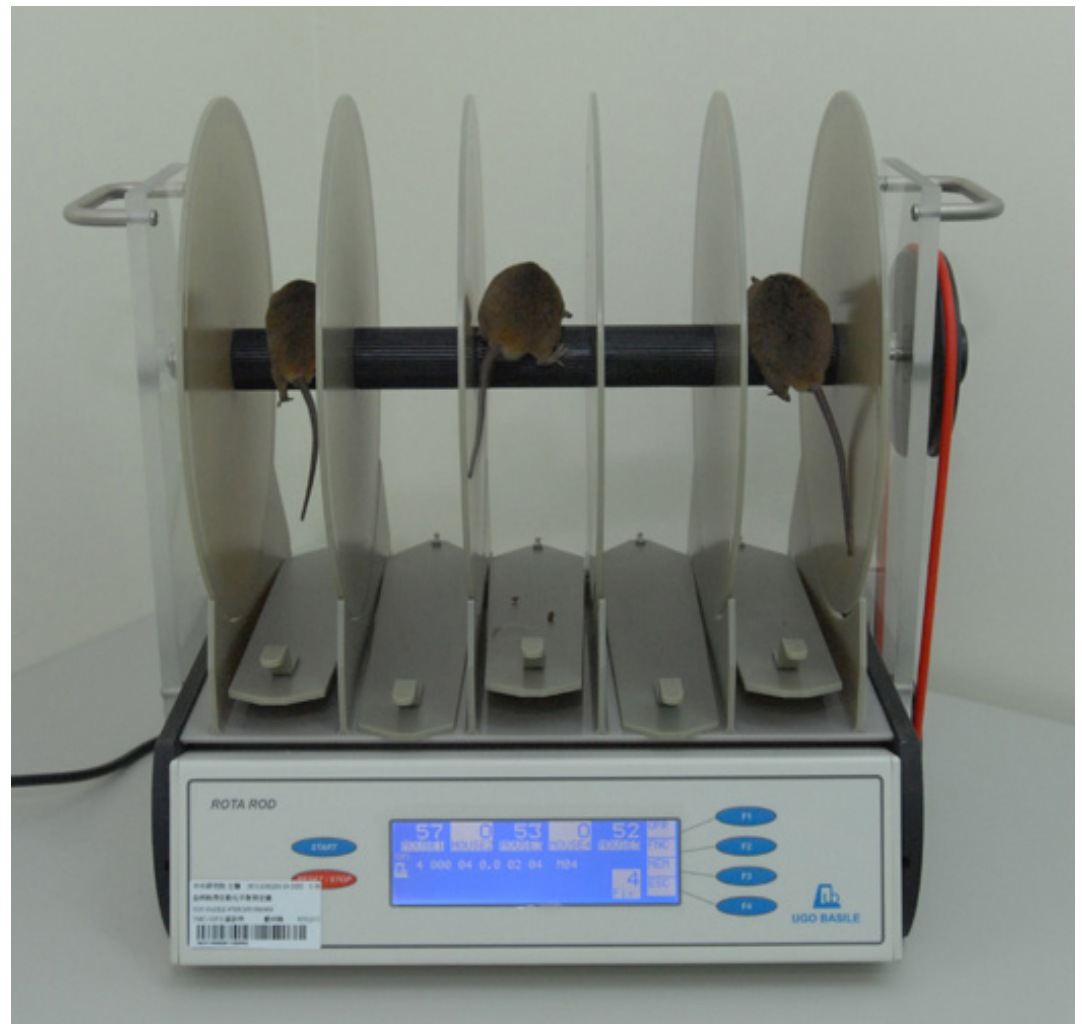

Esquema 4. Test del Rotarod . Los ratones se colocan en una barra acelera de forma constante, y se mide la latencia en caer al suelo (en segundos) como índice de equilibrio y coordinación motora. (Image from Stoelting). 


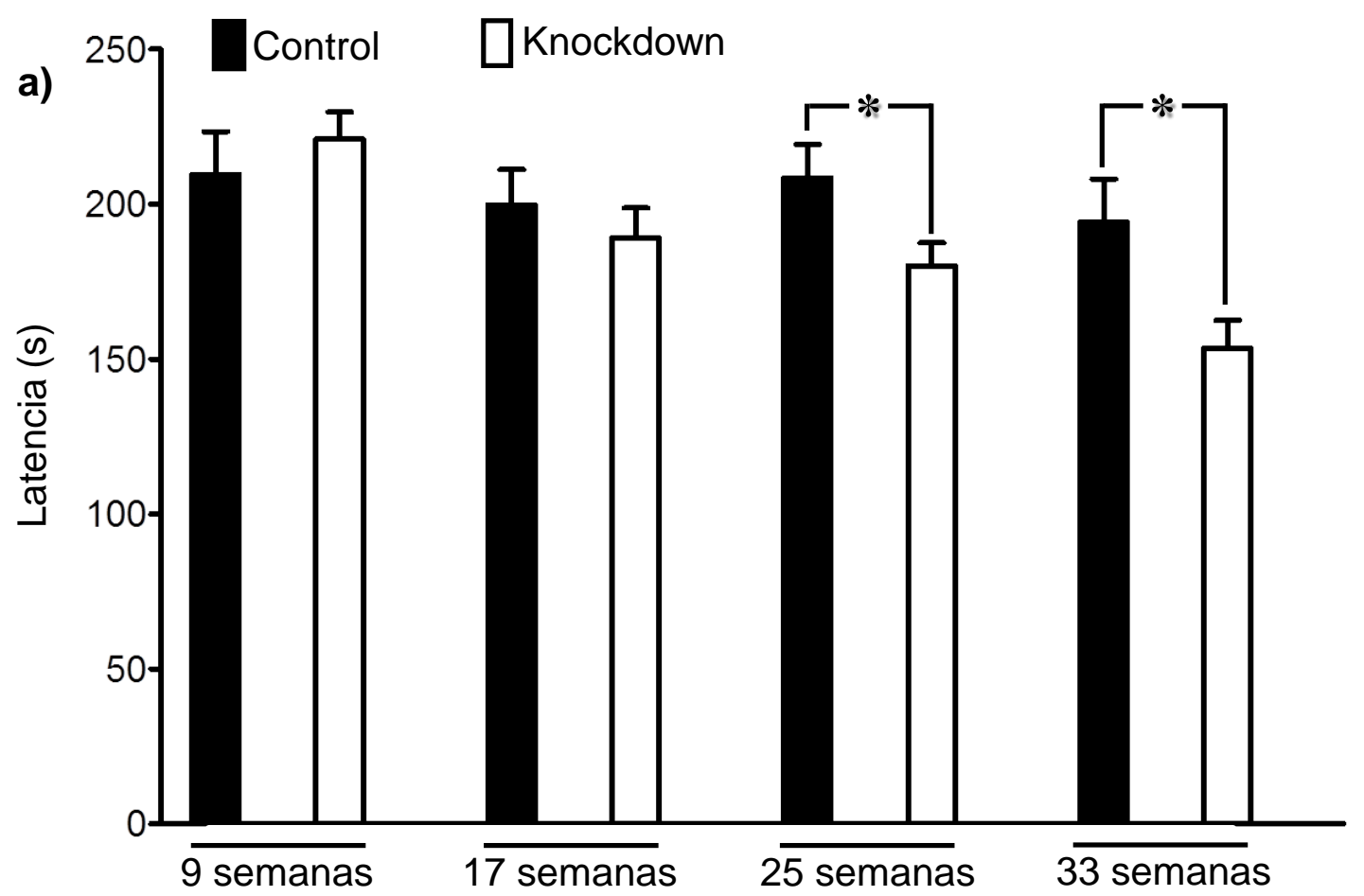

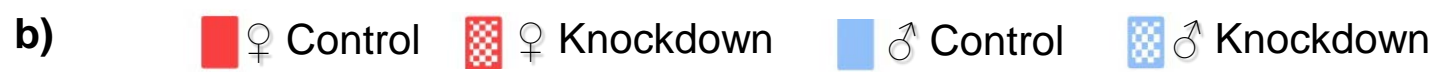

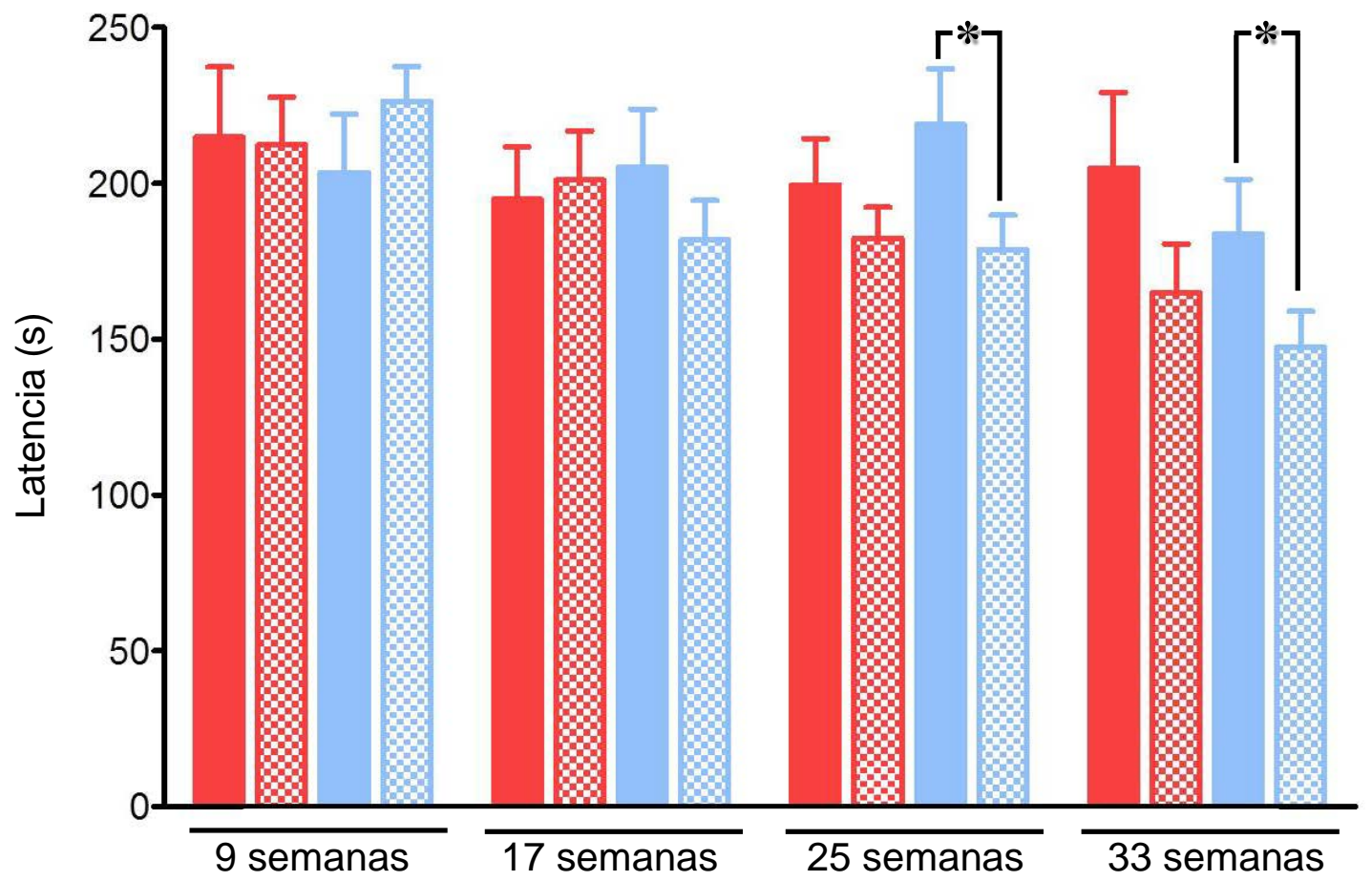

Figura 17. El equilibrio y la coordinación motora están afectados en el ratón CamKIlla-Cre/shGCL floxed. Se midió la latencia de caída de una barra con aceleración constante (Rotarod) en ratones machos y hembra CamKIll $\alpha-\mathrm{Cre}(+/-$ )/shGCL(-/-) (control) y CamKIl $\alpha-C r e(+/-) /$ shGCL(+/-) (knockdown) a las 9, 17, 25 y 33 semanas de edad. a) Datos mostrados según el genotipo $(n \geq 12)$. b) Datos mostrados según el sexo y el genotipo $(n \geq 6)$. Nótese que en las malas ejecuciones en los machos el genotipo knockdown fue un factor importante. $* p \leq 0.05$ ( $t$ de Student). 
a)

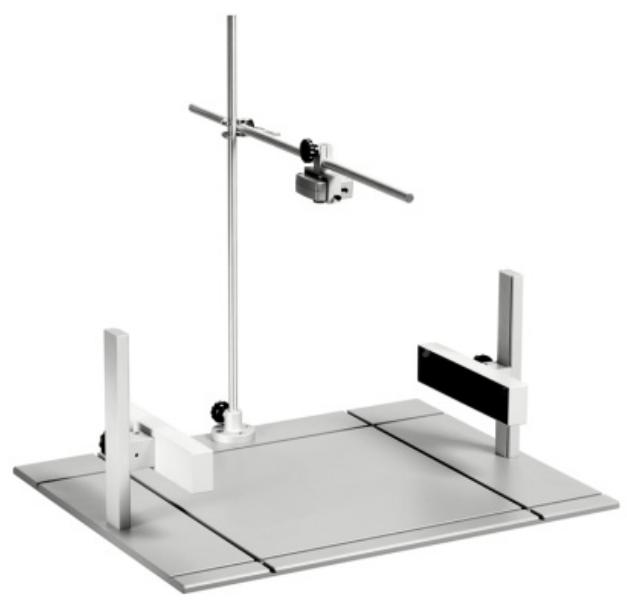

b)

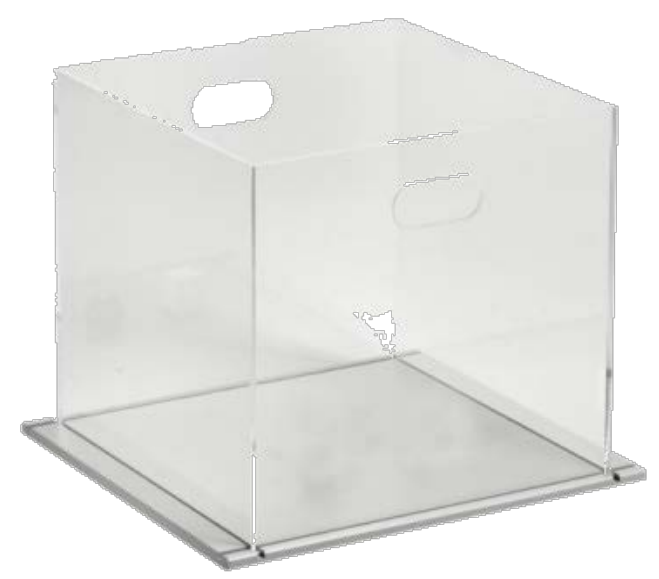

c)

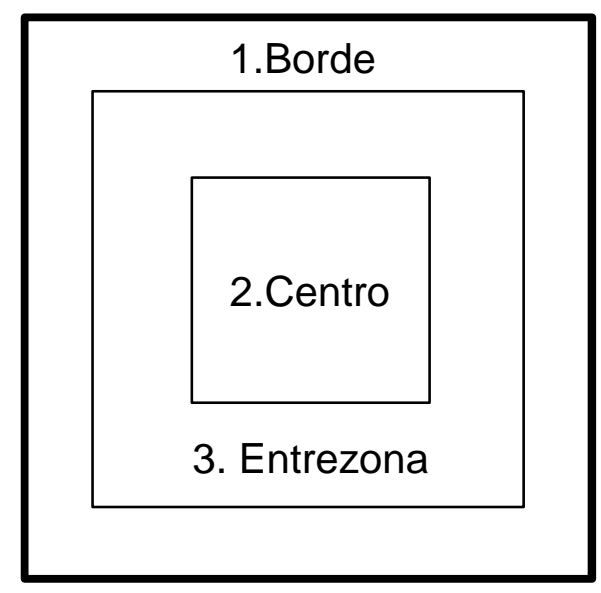

Esquema 5. Test de campo abierto. Descripción del equipamiento utilizado para medir miedo/ansiedad den los ratones. a) Plataforma base. Base color gris claro que contiene una cámara ajustable en altura, un sensor infrarrojo para registrar los movimientos del animal y un detector de alzadas. Los movimientos del animal fueron grabados con el software ANY-maze utilizando la interfaz Ami (no mostrada). b) Accesorio insertable de campo abierto. Inserto negro de Perspex transparente a los infrarrojos de $40 \mathrm{~cm} \times 40 \mathrm{~cm} \times 35 \mathrm{~cm}$ (ancho, largo, alto) (en la imagen se muestra uno transparente). c) Superficie del campo abierto. Fue dividida en las siguientes zonas: 1 . Borde $(8 \mathrm{~cm}$ de ancho), 2. Centro ( $16 \%$ de la superficie total), y 3 . la zona intermedia o entrezona (zona restante). 


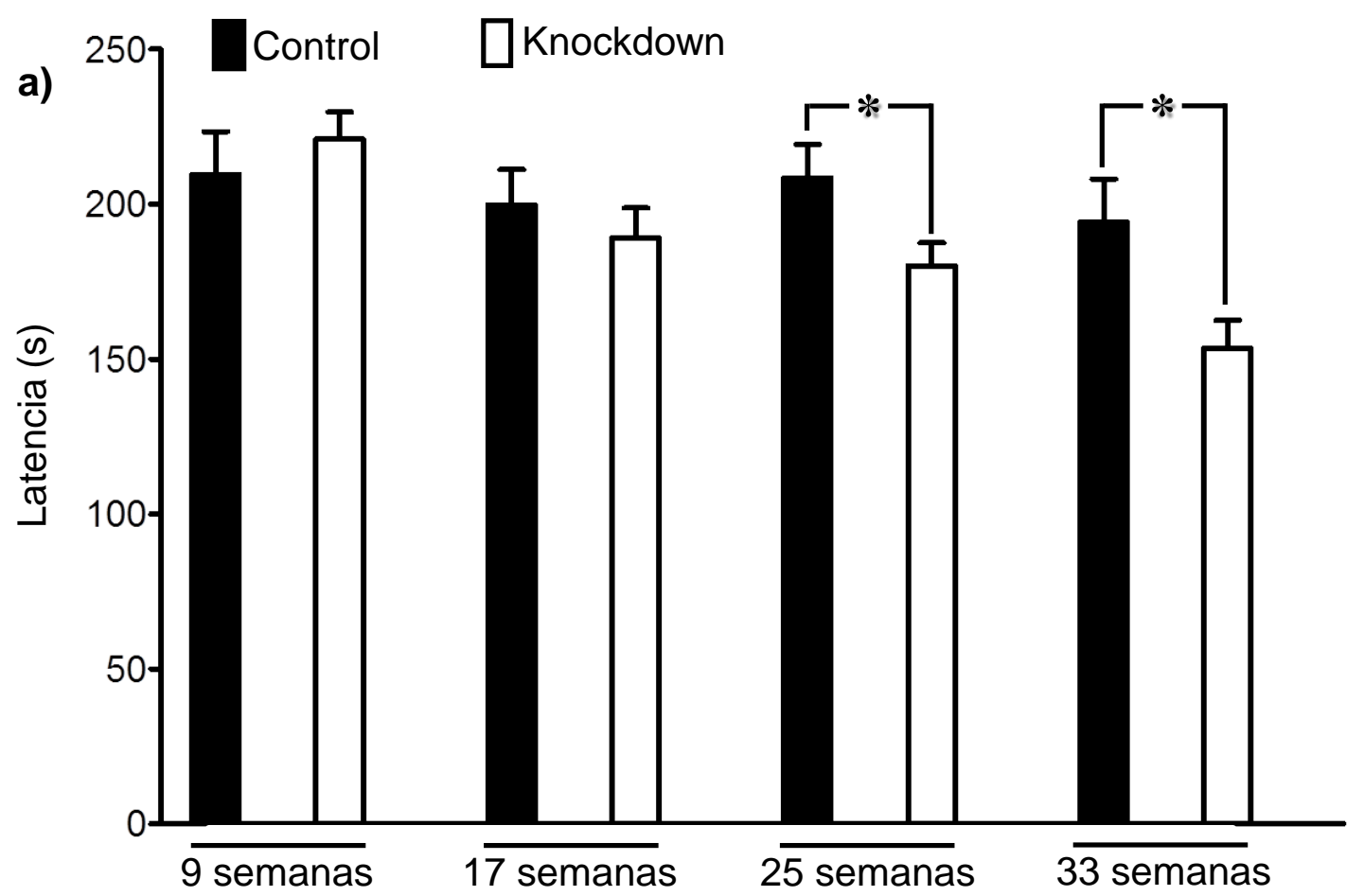

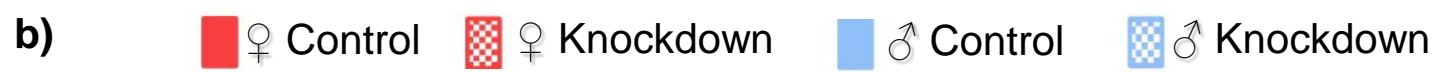

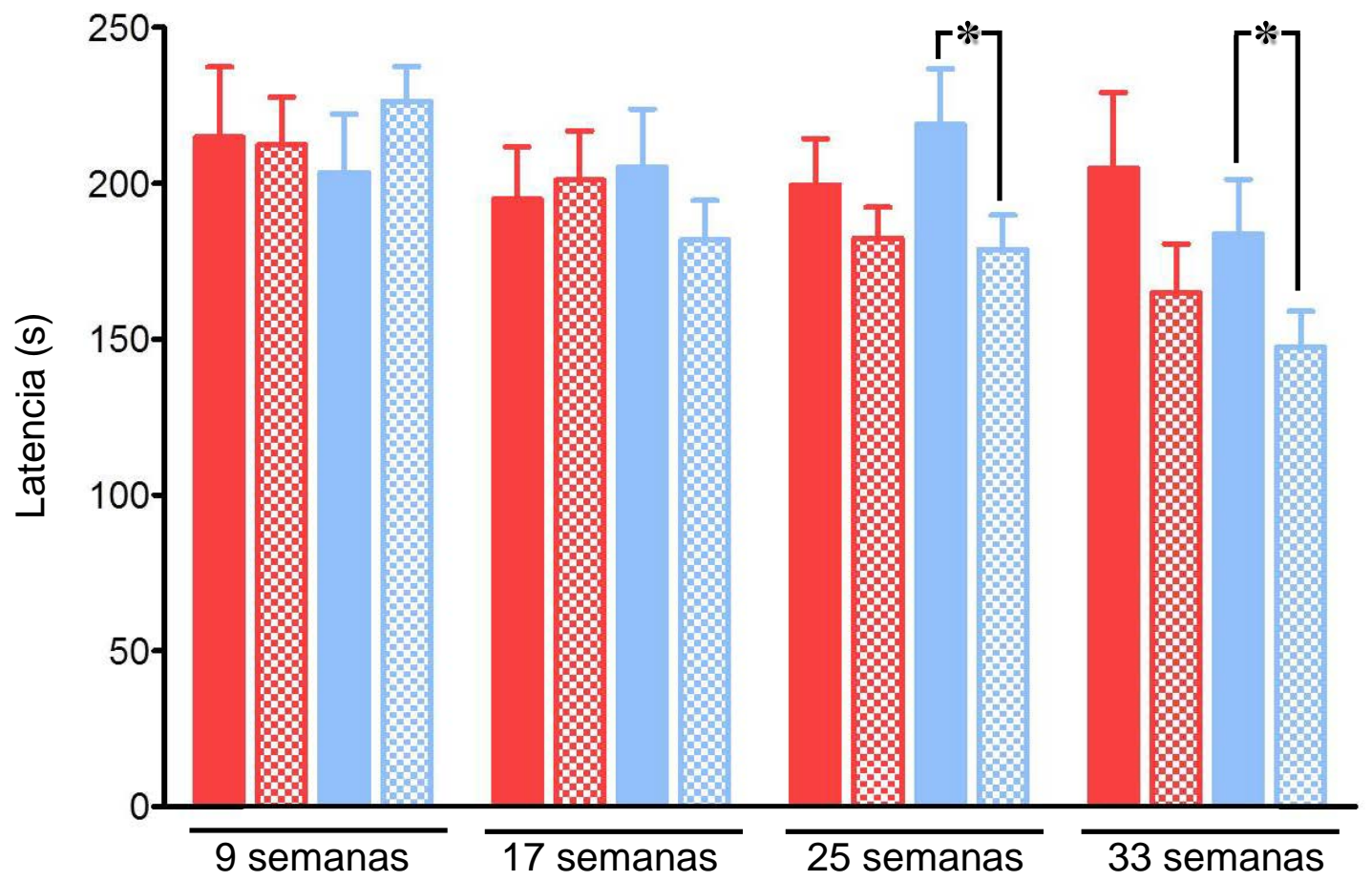

Figura 17. El equilibrio y la coordinación motora están afectados en el ratón CamKIlla-Cre/shGCL floxed. Se midió la latencia de caída de una barra con aceleración constante (Rotarod) en ratones machos y hembra CamKIll $\alpha-\mathrm{Cre}(+/-$ )/shGCL(-/-) (control) y CamKIl $\alpha-C r e(+/-) /$ shGCL(+/-) (knockdown) a las 9, 17, 25 y 33 semanas de edad. a) Datos mostrados según el genotipo $(n \geq 12)$. b) Datos mostrados según el sexo y el genotipo $(n \geq 6)$. Nótese que en las malas ejecuciones en los machos el genotipo knockdown fue un factor importante. $* p \leq 0.05$ ( $t$ de Student). 
a)

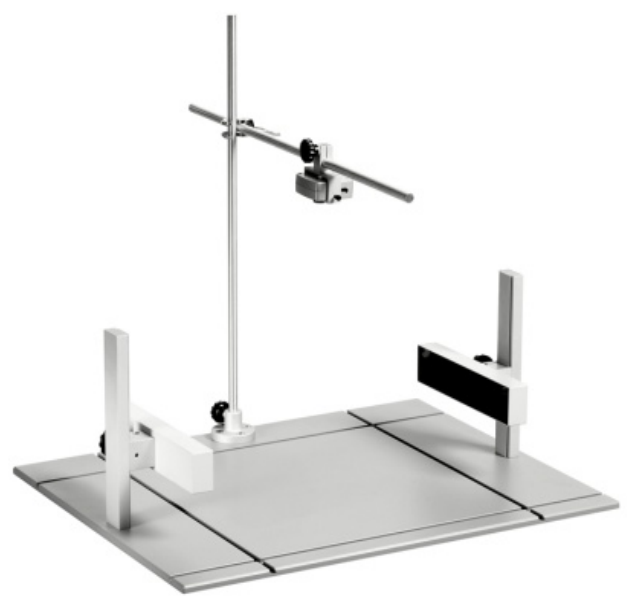

b)

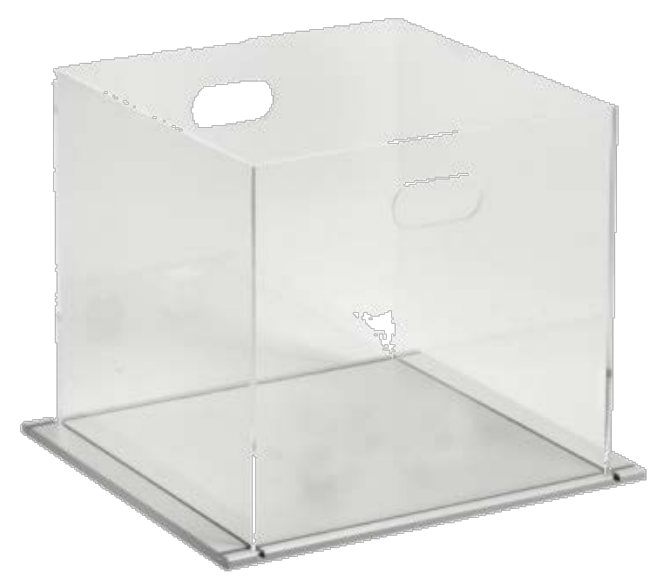

c)

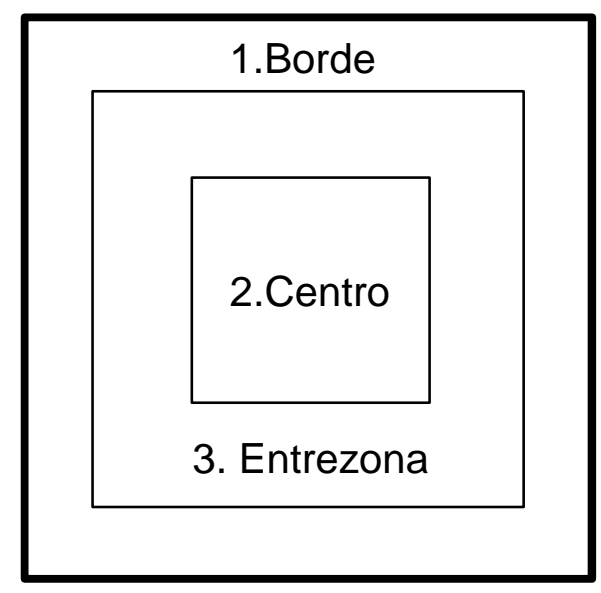

Esquema 5. Test de campo abierto. Descripción del equipamiento utilizado para medir miedo/ansiedad den los ratones. a) Plataforma base. Base color gris claro que contiene una cámara ajustable en altura, un sensor infrarrojo para registrar los movimientos del animal y un detector de alzadas. Los movimientos del animal fueron grabados con el software ANY-maze utilizando la interfaz Ami (no mostrada). b) Accesorio insertable de campo abierto. Inserto negro de Perspex transparente a los infrarrojos de $40 \mathrm{~cm} \times 40 \mathrm{~cm} \times 35 \mathrm{~cm}$ (ancho, largo, alto) (en la imagen se muestra uno transparente). c) Superficie del campo abierto. Fue dividida en las siguientes zonas: 1 . Borde $(8 \mathrm{~cm}$ de ancho), 2. Centro ( $16 \%$ de la superficie total), y 3 . la zona intermedia o entrezona (zona restante). 

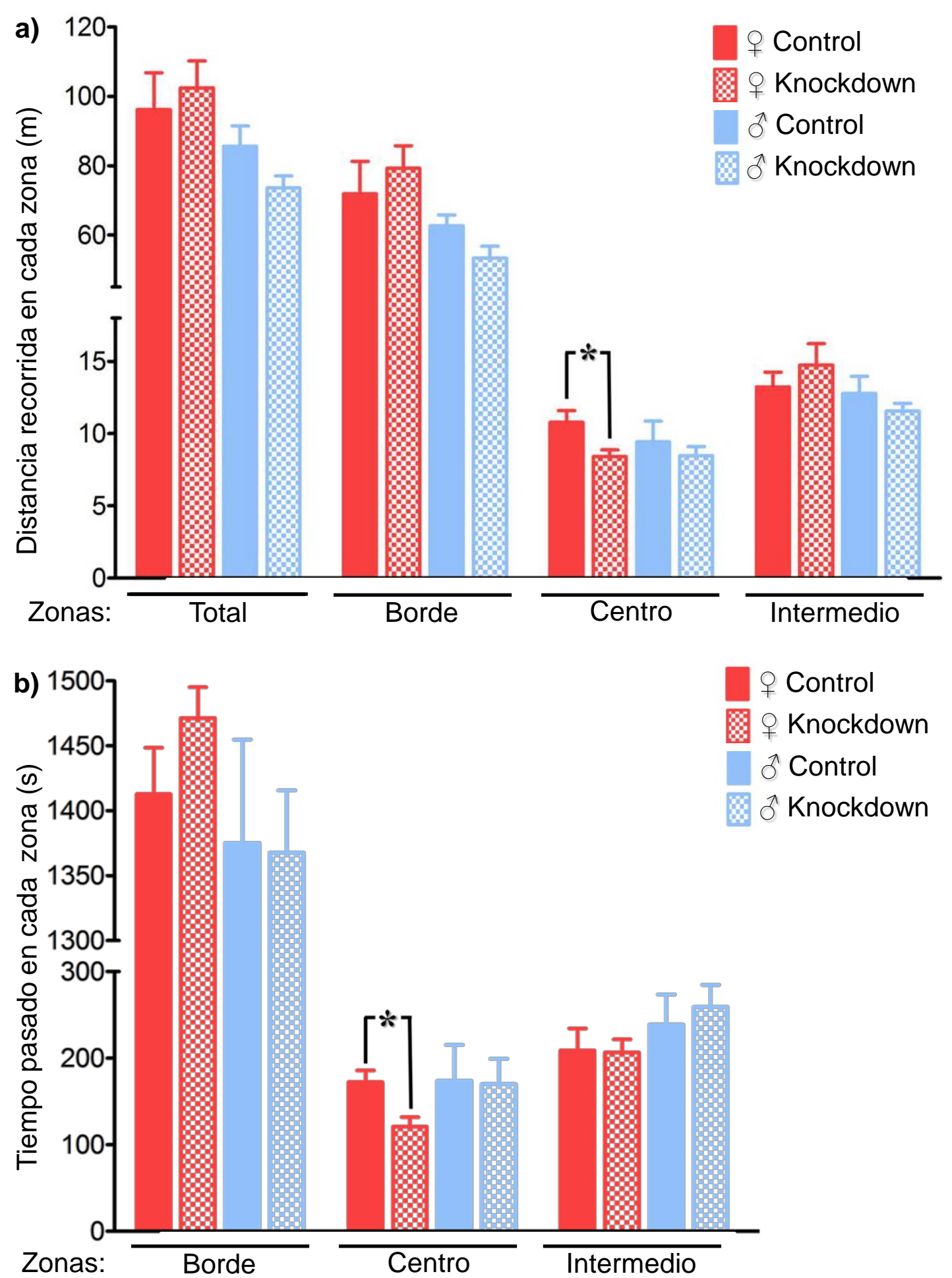

Figura 18. Los ratones hembra CamKIl $\alpha$-Cre/shGCL floxed muestran miedo/ansiedad según el test de campo abierto. Se realizó el test de campo abierto en ratones machos y hembras de once meses de edad del tipo CamKIl $\alpha$ $\mathrm{Cre}(+/-) /$ shGCL(-/-) (control) y CamKIl $\alpha-\mathrm{Cre}(+/-) /$ shGCL(+/-) (knockdown) ( $\mathrm{n} \geq 6$ cada uno). a) Distancia (en metros) recorrida en cada zona durante 30 minutos. b) Tiempo (en segundos) pasado en cada zona. Nótese que las hembras knockdown mostraron un incremento en su miedo/ansiedad tal y como se deduce de la menor distancia recorrida y menor tiempo pasado en la zona central. $* p \leq 0.05$ ( $t$ de Student). (Escala del eje $\mathrm{Y}$ truncada para mayor claridad). 
a)

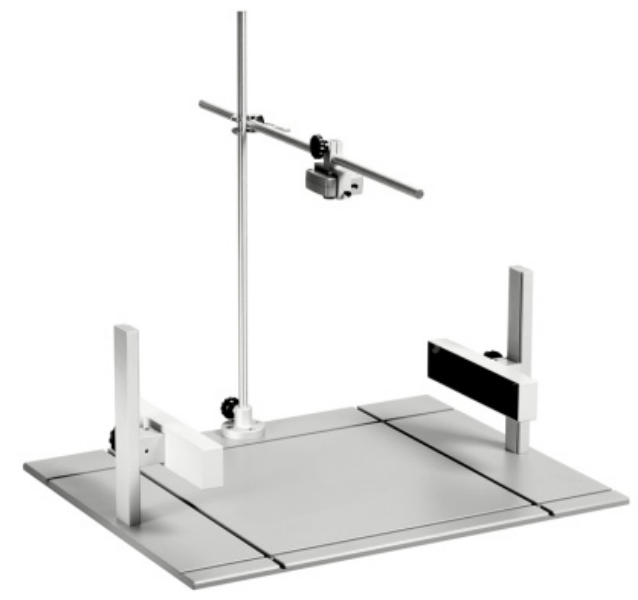

b)

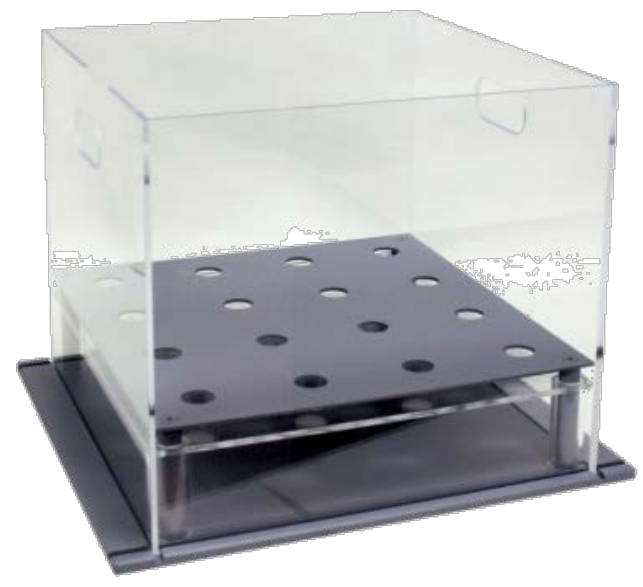

Esquema 6. Test Hole-board. Descripción del equipo automático de Hole-board Stoelting utilizado para medir miedo/ansiedad. a) Plataforma base. Base color gris claro que contiene una cámara ajustable en altura, un sensor infrarrojo para registrar los movimientos del animal y un detector de alzadas. Los movimientos del animal fueron grabados con el software ANY-maze utilizando la interfaz Ami (no mostrada). b) Accesorio insertable y base elevadora para Hole-board. Inserto negro de Perspex transparente a los infrarrojos de $40 \mathrm{~cm} \times 40 \mathrm{~cm} \times 35 \mathrm{~cm}$ (ancho, largo, alto) (en la imagen se muestra uno transparente), ajustado a una base elvadora de $40 \mathrm{~cm} \times 40 \mathrm{~cm}$ (ancho, largo) con 16 agujeros $(3 \mathrm{~cm}$ de diámetro), dispuestos en una configuración de $4 \times 4$ agujeros sobresaliendo 10 $\mathrm{cm}$ por encima del suelo. 


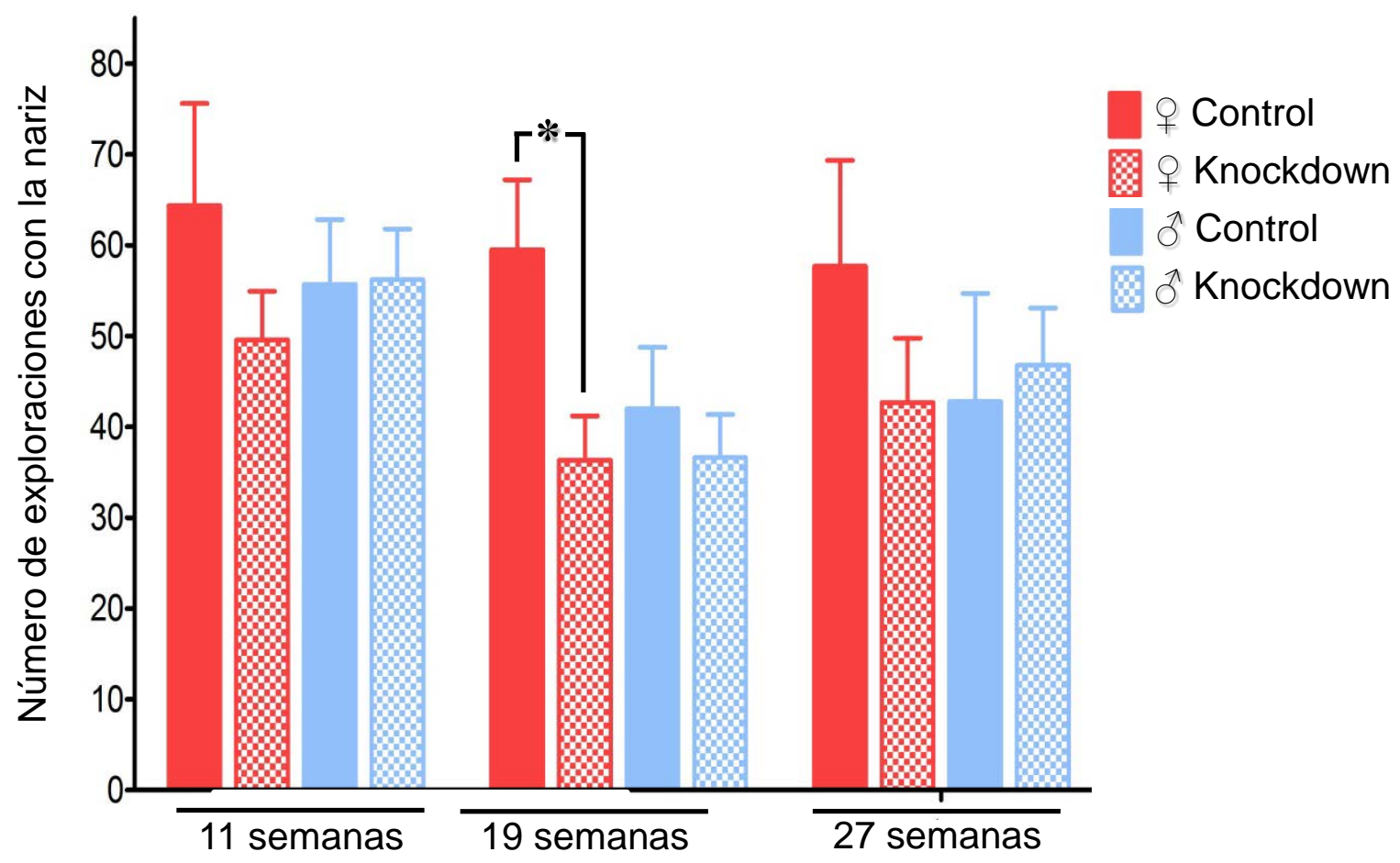

Figura 19. Los ratones hembra CamKIl $\alpha$-Cre/shGCL floxed muestran miedolansiedad, según el test de Hole-Board. El test fue realizado en ratones de 11, 19 y 27 semanas de edad machos y hembras de los tipos CamKIl $\alpha$-Cre(+/)/shGCL(-/-) (control) y CamKIl $\alpha-C r e(+/-) /$ shGCL(+/-) (knockdown) ( $\geq 6$ cada uno). Nótese el descenso en las exploraciones con la nariz en las hembras knockdown, indicando un incremento en el miedo/ansiedad. * $\leq \leq 0.05$ ( $t$ de Student). 
a)

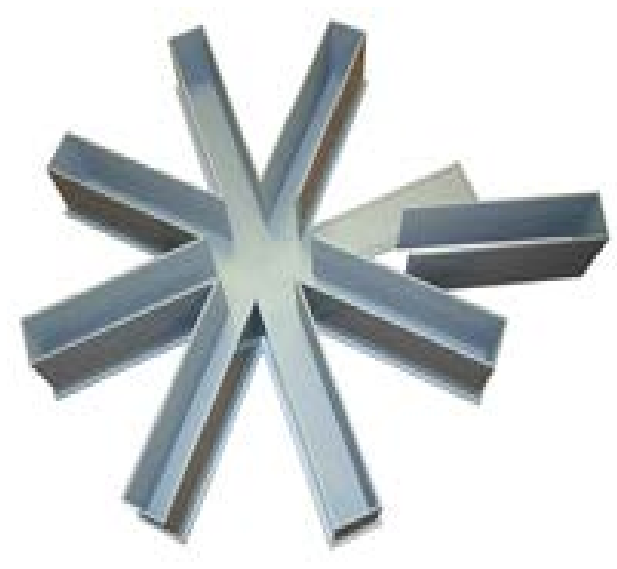

b)

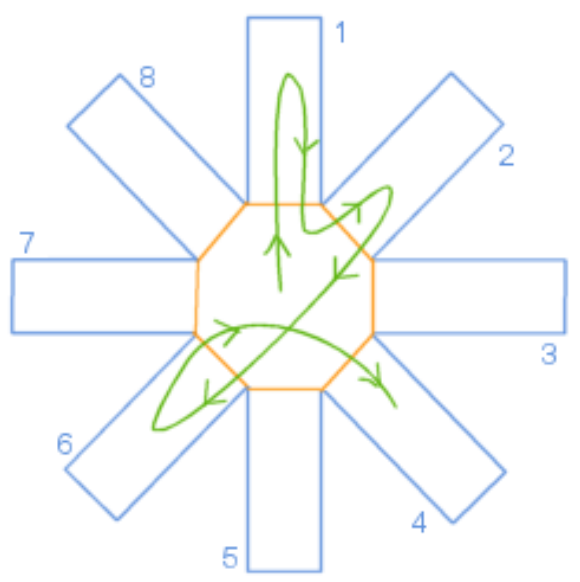

Esquema 7. Test del laberinto de brazos radiales. Descripción del equipo automatizado Stoelting utilizado para medir memoria espacial en ratones. a) Los ocho brazos radiales equidistantes entre sí confluyen en una pequeña plataforma central. Al final de cada brazo se muestra una figura geométrica (no mostrado). Las dimensiones de cada brazo son $5 \mathrm{~cm} \times 35 \mathrm{~cm} \times 9 \mathrm{~cm}$ (ancho, largo, h). Los brazos se encajan en la plataforma base gris claro presentada en los esquemas 5 y 6. b) Representación esquemática de un recorrido típico, que es registrado por un software que cuenta el número de secuencias "sin retorno", en los que el animal recorre todos los brazos sin repetir brazos visitados anteriormente. 

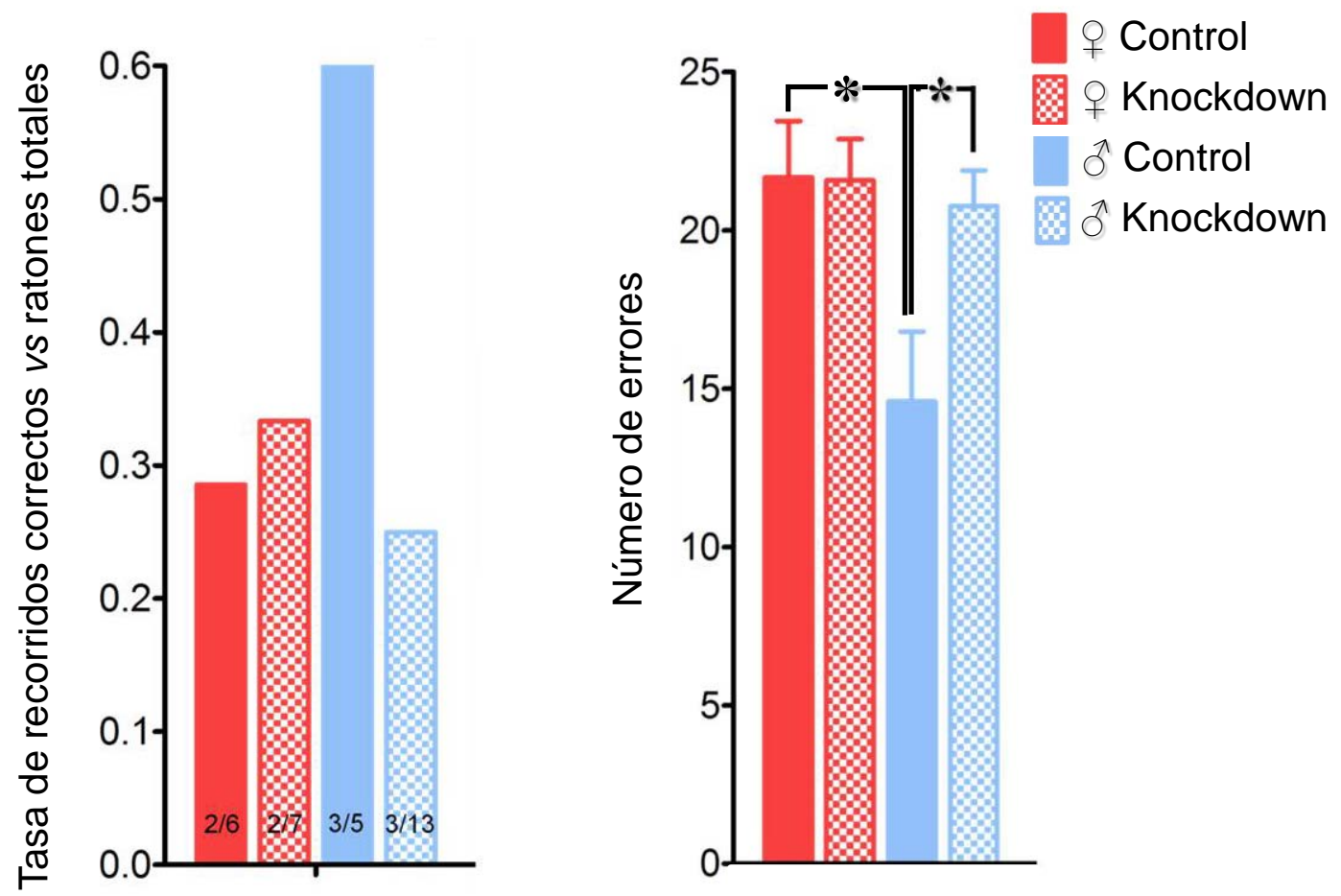

Figura 20. Los ratones macho CamKIll-Cre/shGCL floxed muestran pérdida de memoria espacial, según el test del laberinto de brazos radiales. El test fue realizado en ratones macho y hembra de 15 semanas de edad del tipo CamKIl $\alpha-C r e(+/-) /$ shGCL(-/-) (control) y CamKIl $\alpha-C r e(+/-) /$ shGCL(+/-) (knockdown) ( $n \geq 6$ cada uno). El panel izquierdo muestra el número de recorridos correctos por número de animales totales, mientras que el panel derecho muestra el número total de errores cometidos. Nótese que los machos control realizaron el test mejor que las hembras controles (mayor tasa de recorridos correctos/número total de animales), sugiriendo mejor memoria espacial en machos; sin embargo, esa habilidad de los machos se perdió en el grupo knockdown. * $\leq 0.05$ ( $t$ de Student). 
A la vista de los resultados presentados en esta Tesis Doctoral, hemos obtenido las siguientes conclusiones:

1. Hemos generado un nueva herramienta génica basada en el sistema Cre-LoxP para interferir in vivo, mediado por un evento de recombinación, la síntesis de cualquier proteína en un ratón, de una forma tejido específica y temporalmente controlada. Para este propósito, hemos generado dos construcciones para obtener ratones transgénicos con caída de función proteica o knockdown, bien por microinyección en ovocitos o por recombinación homóloga de células stem embrionarias (ES). Estas herramientas son adecuadas para la generación de nuevos modelos experimentales de knockdown en el futuro.

2. Hemos generado una nueva línea de ratón transgénico basada en el sistema Cre-LoxP $\left(s h G C L^{\text {floxed }}\right.$ ) que puede ser usado para desencadenar interferencia por knockdown de la glutamato-cisteina ligasa (GCL), la enzima limitante de la biosíntesis de glutatión, de una forma tejido específica y temporalmente controlada. Por lo tanto, esta línea de ratón $s h G C L^{\text {floxed }}$ es adecuada para la investigación in vivo de estrés oxidativo en tejidos específicos.

3. Mediante el cruce de la línea transgénica $s h G C L^{\text {floxed }}$ con ratones CamKII $\alpha-C r e$, que expresan la recombinasa Cre gobernada bajo el control del promotor neuronal de la proteína $\mathrm{Ca}^{2+}$-calmodulina kinasa-II $\alpha$ (CamKII $\alpha$ ), obtuvimos una progenie que presentaba signos de estrés oxidativo en neuronas post-natales $\mathrm{CamKII}^{+}$del sistema nervioso central, particularmente en el estriado y en el hipocampo. Estos resultados proporcionan la prueba de concepto de que los ratones $s h G C L^{\text {floxed }}$ son funcionales, y por lo tanto desencadenan estrés oxidativo en tejidos específicos de forma temporalmente controlable.

4. Mediante el estudio de los signos comportamentales en ratones adultos obtenidos mediante el cruce de ratones shGCL $L^{\text {floxed }}$ con ratones CamKII $\alpha$-Cre, observamos que sólo los ratones que mostraban signos de estrés oxidativo en las neuronas postnatales CamKII $\alpha^{+}$, presentaban alteraciones, dependientes del sexo, en la 
coordinación motora y la función cognitiva. Estos resultados indican que la inducción in vivo de estrés oxidativo causado por la deficiencia de glutatión en neuronas del estriado y del hipocampo es capaz de alterar la correcta funcionalidad del cerebro, asemejándose a enfermedades mentales (tales como la ansiedad), demencia y enfermedad de Parkinson. 


\section{Acknowledgments}

Danke, Eskerrik asko, Gracias, Gràcies, Grazias, Grazie, Go raibh maith agat, Hvala, Merci, Obrigada, спасибо, Tak, Thanks, شَكرا ， 谢谢. 
Esta tesis es el resultado no sólo de mi esfuerzo personal, sino también al resultado de la interacción de mucha gente con la que he "co-localizado" a lo largo de todos estos "incontables" años. Todos me enseñaron algo, otros me guiaron cuando estaba perdida y otros aliviaron mis cargas. Gracias a todos ellos soy lo que soy y estoy más que satisfecha con el resultado.

Gracias a mis directores Juan Pedro Bolaños Hernández y Angeles Almeida Parra. Gracias por acogerme cuando era una chiquilla, preocuparse por mí, enseñarme, dirigirme y alentarme en los tiempos duros -que lo fueron mucho. Les agradezco también su continuo esfuerzo por buscar financiación que ha permitido "mantenerme" más allá de la "vida media” de un becario.

Gracias a la financiación del gobierno español bajo todas y cada una de sus cambiantes y caóticas denominaciones: MEC, MECyD, MECPSyD y el prometedor MICIIN finalmente reducido a una simple secretaría de estado de investigación en el MINECO. Gracias por las diferentes becas que he disfrutado durante toda mi formación, y en especial por el Programa Nacional de Formación de Profesorado Universitario (PNFPU), del que he sido beneficiaria, así como diversos contratos de investigación. Gracias también a la organización EMBO, por financiar mi estancia en el extranjero.

Gracias a otros científicos con los que tuve el gusto de trabajar y que tan bien me acogieron durante mis estancias con ellos: Abraham Acevedo Arozena y Valter Tucci en el MRC de Harwell, Fernando de Castro Soubriet en el Hospital de Parapléjicos de Toledo y finalmente a Lisardo Boscá Gomar y Paloma Martín Sanz cuando estaban en el CNIC y que ahora están en el IIB. Dentro de la Universidad, gracias a las personas que abrieron las puertas de su laboratorio para hacer "mini-estancias", aprender técnicas, usar sus equipos o simplemente dar sabios consejos: Emilio Fernández Sánchez, Dionisio Martín Zanca, Almudena Velasco Arranz, Carmen Guerrero Arroyo, Javier Yajeya Pérez, Juan Carlos Arévalo Martín, Irene García Higuera, Sergio Moreno Pérez, Aránzazu Tabernero Urbieta, Josefa Martín Barrientos y José María Medina Jiménez. Gracias a Lluis Montoliú por sus consejos y mi agradecimiento a las siguientes 
personas por el material tan amablemente prestado: Andrew P. McManhon por la construcción CreER ${ }^{\mathrm{TM}}$, y Johannes Hirllinger por los ratones GFAP-CreER2T.

Gracias a todos mis compañeros de laboratorio -que han sido muchos a lo largo de todos estos años- por los tiempos buenos y los menos buenos, las charlas productivas e improductivas, los consejos, la ayuda y sobre todo las risas -que hubo a montones. A mis compañeros de laboratorio actual: Patricia Rodríguez Rodríguez, Daniel Jiménez Blasco, Irene López Fabuel, Raquel Requejo Aguilar, María Delgado Esteban, Miguel Veas-Pérez de Tudela Rodríguez, Verónica Bobo Jiménez, Rebeca Lapresa Ruiz de Gauna, Cristina Rodríguez González y en especial a Mónica Resch Beusher, Silvia González Fernández (que sigo llamando compañera) y Mónica Carabias Carrasco, por todos los ratones que os han mordido. A mis compañeros que ya se fueron pero que dejaron su esencia: Rubén Quintana Cabrera, Carolina Maestre Ferrín, Virginia Fernández Chanca, Julia Cuende Villasur, Ángel Herrero Méndez, Juan Ignacio Díaz Hernández, Paula García Nogales, Pilar Cidad Velasco, Silvia Salas Pino, Victoria Vega Agapito, María del Carmen Alguero Martín, Ma Carmen Muñiz Martín, Rosario Valle Vicente, Rayito Rivera Hernández y Fátima Only. A los compañeros "extemporáneos" que hicieron escala con nosotros: Carolina Stefani, Yanina Benedetti, Anna Mathia Klawonn, Elèna Chiricozzi, Andrew Johnston Duncan, Pedro Antonio Cisternas, Octavio García García, Dennis Herrmann, Roberta Eckert, Nadja Müller, Javier García Bueno, Rita Vaz, Blandina Esteves, Beatriz Bustillo Ramírez, Jorge Domínguez Andrés y Javier Emperador Melero. Gracias a los compañeros de otros laboratorios en los que yo fui "extemporánea": en Harwell, Silvia Corrochano, Pat Nolan y sus chicas, Mohideen Quwailid, Laura Wisby, Andrew Parker, Nathan Absalom, y otros tantos que no puedo recordar; en Toledo a mis compañeros del GNED que tan bien me trataron: Francisco Javier Arenzana Sanagérico, Diego Clemente López, Diego García González, Verónica Murcia Belmonte, Cristina Ortega Muñoz, Pedro Esteban, Laura García Fernández, Isabel Machín Díaz, Amelia González López; cuando estuve en el CNIC gracias Amelia Fernández Martínez, Rafael Mayoral Moñibas y otros muchos cuyos nombres cayeron en el olvido; y por último gracias a las "chicas" de Dionisio Martín Zanca, Laura Andrés Martín y Laura Parrilla Monge. 
Gracias a la gente de otros laboratorios de la Universidad de Salamanca que me ayudaron de una u otra forma: Ester Gangoso Rodríguez, Vega Tello, José Carlos Valle Casuso, Alejandro García García, Erica Polo Hernández, Teresa Paíno Gómez, Ángel Arroyo Martín, André Fabio Bento Abreu, Ana Velasco Criado, Maruan Hijazi, Sofía Muñoz Félix, María Francisca Pastor Mansilla, Pablo Martínez Becerra, Alba García Blázquez, José Luis Sardina Ortega, Guillermo López Ruano, Marta Rodríguez Romero, Sara Cuadrado Castaño, Fátima Macho Sánchez-Simón, Adrián Santos Ledo, Rosario Sánchez González, Flora María Antunes Ferreira, Maite Ogueta Gutiérrez, Laura Calvo Enrique, Saray López Benito, Saúl Herranz Martín, David Díaz López, Tao Yu, Miguel Moyano Téllez, Antonio Escudero Paniagua, Marta Parrilla Monge y Begoña Anta Rodríguez.

Gracias a mis profesores de la carrera, especialmente los que me enseñaron asignaturas que han tenido repercusión en el desarrollo de esta tesis y que no he mencionado en otro lugar: Angel Hernández Hernández, Enrique Villar Ledesma, Pablo Hueso, Casilda López Mediavilla, Valery L. Shnyrov, Marcial Llanillo Ortega, Jiménez, Isabel Muñoz Barroso, Ma Victoria García García, José Manuel González de Buitrago Arriero, M. Carmen Arizmendi López, María C. Juanes de la Peña, María Nieves Pérez González, David Rodríguez García, Raquel Emilia Rodríguez Rodríguez, María del Carmen Sánchez Bernal, Fernando Leal Sánchez y Enrique Iturriaga Urbistondo.

Dentro de los servicios que ofrece la universidad quiero dar las gracias al Servicio de Experimentación Animal: Luis Muñoz de la Pascua, Manuel A. Sánchez Martín, Carmen Rodríguez y al resto de técnicos y cuidadores. Administrativamente gracias al secretario del Departamento de Bioquímica y Biología Molecular Javier Escudero, y en la agencia de Gestión de Investigación a Araceli Merino Monge, por hacerme la vida más fácil con los innumerables papeleos, que tanto gustan a los que no tienen que rellenar ninguno. Gracias a la Oficina de Transferencia de Resultados de Investigación, por su ayuda con con nuestro intento de patente y a Genoma España por financiarla. Gracias al personal de los dos institutos a los que hemos pertenecido al Instituto de 
Neurociencias de Castilla y León y al Instituto de Biología Funcional y Genómica. En cuanto al servicio de microscopía confocal quiero agradecer a Carmen J. Castro Pichel, David Jimeno García y Ángel Luís Prieto Martín por su inestimable ayuda. Fuera de la universidad quiero agradecer al Servei de Proteòmica i Genòmica de la Universitat de Lleida, en especial a Isabel Sánchez y a Joaquim Ros Salvador y a A Ralf Dringen de la Universidad de Bremen y João Laranjinha de la Universidad de Coimbra, por sus gratificantes palabras y evaluación de esta Tesis

Gracias a mis amigos de la carrera, del trabajo y de los que te encuentras por la vida. Aquí están lo que todavía no he mencionado anteriormente: Carmen García Herrero, Lucia Pérez Cabornero, Silvia Lisa Ferrer, Alfonso Gallego Sánchez, , Diego Arceredillo Alonso, José Ma Benjumea Granado, Niamh Tuite, Paula Martín Orviz, Juan Ignacio Martín Orviz, Carmen Rosa Orviz Álvarez, Ignacio Martín, Luis Jiménez Labaig y Juan Sanz González.

Gracias a mi familia, que están ahí tanto a las duras como a las maduras. A mis padres, Santiago Fernández Alonso y Sabina Fernández Alonso, a los que yo llamo Papá y Mamá; a mis hermanos Silvia Fernández Fernández y Saúl Fernández Fernández, mi sobrina Sara Fernández Fernández y mi cuñada Susana Miñambres Pérez. Gracias al resto de mis tíos, primos y sobrinos segundos que son muchos (unos cien y creciendo) y a mi futura familia política. En especial a mi tía Manuela Alejo Montaño, mi tío Jesús Fernández Alonso y un recuerdo especial a los que ya no están con nosotros. Por último gracias a la persona que menos se merece un agradecimiento tan descafeinado, Fernando León Lobera, y al que le doy aquí un gran GRACIAS.

Mi intención inicial fue hacer unos agradecimientos breves y discretos. Indudablemente se me ha ido de la mano. El problema es que no pude hacerlos más cortos y al hacerlos tan cortos me he quedado corta y lo siento. 
